\title{
US Nation-Building in Afghanistan
}




\section{US Nation-Building in Afghanistan}

Why has the US so dramatically failed in Afghanistan since 2001? Dominant explanations have ignored the bureaucratic divisions and personality conflicts inside the US state. This book rectifies this weakness in commentary on Afghanistan by exploring the significant role of these divisions in the US's difficulties in the country that meant the battle was virtually lost before it even began. The main objective of the book is to deepen readers' understanding of the impact of bureaucratic politics on nation-building in Afghanistan, focusing primarily on the Bush administration. It rejects the 'rational actor' model, according to which the US functions as a coherent, monolithic agent. Instead, internal divisions within the foreign policy bureaucracy are explored, to build up a picture of the internal tensions and contradictions that bedevilled US nation-building efforts. The book also contributes to the vexed issue of whether or not the US should engage in nation-building at all, and if so under what conditions.

Dr Conor Keane has degrees in law and politics, and a doctorate on nationbuilding in Afghanistan from Macquarie University. His research interests include counter terrorism, state building, bureaucratic politics and US foreign policy. He has published several articles on these topics in journals such as Armed Forces \& Society and International Peacekeeping. 



\title{
US Nation-Building in Afghanistan
}

\author{
Conor Keane
}

\author{
Routledge \\ 命 Taylor \& Francis Group


First published 2016

by Routledge

2 Park Square, Milton Park, Abingdon, Oxon OX14 4RN

and by Routledge

711 Third Avenue, New York, NY 10017

Routledge is an imprint of the Taylor \& Francis Group, an informa business

\section{(C) 2016 Conor Keane}

The right of Conor Keane to be identified as author of this work has been asserted by him in accordance with sections 77 and 78 of the Copyright, Designs and Patents Act 1988.

All rights reserved. No part of this book may be reprinted or reproduced or utilised in any form or by any electronic, mechanical, or other means, now known or hereafter invented, including photocopying and recording, or in any information storage or retrieval system, without permission in writing from the publishers.

Trademark notice: Product or corporate names may be trademarks or registered trademarks, and are used only for identification and explanation without intent to infringe.

British Library Cataloguing in Publication Data

A catalogue record for this book is available from the British Library

Library of Congress Cataloging-in-Publication Data

Names: Keane, Conor.

Title: US nation building in Afghanistan / by Conor Keane.

Other titles: United States nation building in Afghanistan

Description: Farnham, Surrey, UK; Burlington, VT: Ashgate, 2016. | Includes bibliographical references and index.

Identifiers: LCCN 2015030413 | ISBN 9781472474841 (hardback: alk. paper) | ISBN 9781472474858 (ebook) | ISBN 9781472474865 (epub)

Subjects: LCSH: Nation-building-Afghanistan. | Postwar reconstructionAfghanistan. | Postwar reconstruction-Government policyUnited States. | United States-Foreign relations-Decision making. | United States-Foreign relations-Afghanistan. | Afghanistan-Foreign relations-United States.

Classification: LCC DS371.4 .K397 2016 | DDC 958.104/72-dc23

LC record available at http://lccn.loc.gov/2015030413

ISBN: 9781472474841 (hbk)

ISBN: 9781315548623 (ebk)

Typeset in Times New Roman by Apex CoVantage, LLC 


\section{Contents}

Acknowledgements viii

1 Introduction 1

Current Literature on Nation-Building in Afghanistan 3

Nation-Building and Bureaucratic Politics in Afghanistan 8

Method and Structure 11

\section{PART I}

Background and Methodology

2 Nation-Building and the Afghan State

What is Nation-Building? 18

Nation-Building Practice 24

A History of the Afghan State 28

Conclusion 34

3 Bureaucratic Politics and Nation-Building

The Rational Actor Model 36

The President and the Bureaucracy 41

A New Bureaucratic Politics Model 44

Conclusion 51

\section{PART II}

US Nation-Building in Afghanistan

4 The US Foreign Policy Bureaucracy and Nation-Building in Afghanistan

The Military Establishment 56

The State Department 63 
vi Contents

USAID 68

The Counter-Bureaucracy 71

Inter-Agency Problems 74

Conclusion 86

5 Security

The International Security Assistance Force 88

US Efforts to Train the Afghan National Army 91

US Efforts to Train the Afghan National Police 94

The CIA and Afghanistan's Warlords 105

Conclusion 110

6 Infrastructure Development

The Military Establishment's Programme 112

USAID's Programme 116

Infrastructure Development Projects 122

Regulation and Oversight 132

Congress 135

Conclusion 136

7 Counter-Narcotics, Law and Governance

Counter-Narcotics Programme 139

The Legal System 151

Governance 158

Conclusion 165

\section{PART III}

Avenues for Inter-Agency Cooperation

8 The Failure of Collaborative Mechanisms

Government-Based Mechanisms for Cooperation 169

Individuals as a Conduit for Cooperation 176

Non-Governmental Ideas on Inter-Agency Collaboration in Afghanistan 185

The Shortness of Staff Postings 189

Conclusion 191

9 Provincial Reconstruction Teams: A Microcosm of US

Nation-Building in Afghanistan

Praise and Critique 194

The US Military 195

Civilian Agencies 199 
The Counter-Bureaucracy, USDA and PRTs 202

Conclusion 203

10 Conclusion

204

Bureaucratic Politics and Nation-Building in Afghanistan 205

Collaborative Mechanisms 210

Bibliography

Index 


\section{Acknowledgements}

In the course of researching and writing this book I have received assistance from a number of parties. Professionally, I owe the most significant debt to Dr Lloyd Cox. I would also like to acknowledge Dr Ashley Lavelle, Dr Steve Wood and Associate Professor Morris Morley for taking the time to look at my chapters and offer advice and encouragement. I extend my gratitude to the senior US officials who were willing to permit me to interview them at length. The insights they provided were invaluable.

Personally, I would like to express my gratitude to my brother, for his empathy, and my father, for his unfailing patience and understanding. But most of all I would like to thank my mother, who since I began undergraduate studies has been an ever-willing listener and proofreader. She has pushed me beyond boundaries of self-doubt that I surely would not have conquered otherwise.

Mum, I dedicate this book to you. 


\section{Introduction}

On 11 September 2001 an event occurred that impacted significantly on the shape and nature of US foreign policy. The destruction of the World Trade Center, damage to the Pentagon, and the deaths of almost 3,000 US citizens, could not go unanswered. An overwhelming majority of a stunned US population looked to the government and military for retribution. In this heated political climate, President George W. Bush declared a 'Global War on Terror' (GWOT), a protracted conflict against an insubstantial enemy. Richard Myers, the Chairman of the Joint-Chiefs of Staff, described it as 'a different kind of conflict . . . unlike any other in recent American history'. This would be a conflict without temporal and spatial horizons, where non-state, terrorist actors were as much a target of US military action as the states that harboured them.

Barely a month after 9/11, the first battleground in the GWOT became Afghanistan. Here the Taliban government was sheltering Al Qaeda, the fundamentalist, Islamic terrorist group responsible for the attacks. Bush called for the Taliban to hand over Al Qaeda's leader, Osama Bin Laden, and their refusal to do so precipitated a US invasion. Rallying under the banner of national self-defence, the organs of the US government swiftly mobilized for a military strike aimed at regime change. Following a resounding military victory, however, the ties that bound the foreign policy machine together began to fray, as the realities of the political and military situation unfolded over the coming months and years.

As the Taliban regime crumbled in the face of American military might, some educated Afghans and many more Americans hoped that a stable and representative government could replace it. But a smooth transition to Western-style democracy was always an unlikely, if not altogether utopian, challenge, given Afghanistan's economic underdevelopment, ethno-sectarian fissures, and institutional fragility born of decades of military conflict and authoritarian rule. From 2001 to 2003, the scale and complexity of this challenge was not something the Bush Administration seriously considered. On the one hand, the abstracted rhetoric of long-term political goals and ambitions envisaged the cultivation of a stable, pluralistic and representative Afghan government. On the other hand, the human 


\section{Introduction}

and material resources on which such an outcome would be premised were never forthcoming. Consequently, US insouciance in the years immediately after the invasion, thinly disguised beneath the euphemistic language of having a 'light footprint', contributed to the rise of a ferocious and destabilizing insurgency. This heralded the return of the Taliban as a significant political force. As the insurgency intensified, policymakers reappraised the situation and emphasized the need for a comprehensive, whole-of-government approach.

Despite some limited progress, a refurbished, 'whole-of-government' approach to Afghanistan's problems fell far short of its objectives. By 2008, a quarter of Afghanistan's population still did not have access to clean water, and 50 per cent of Afghan children were malnourished. Over six million people required food aid, including approximately 172,000 teachers who were not able to support themselves. ${ }^{2}$ There was also rampant unemployment due to a lack of industrial or farming opportunities. It has been estimated that 60-70 per cent of those who joined the Taliban between 2001 and 2008 did so because of a lack of income. ${ }^{3}$ By 2010, Afghanistan remained bereft of a national road network, and the highways that the US had constructed were used for drug trafficking and extortion. Schools lacked equipment and sometimes even a schoolroom, and there was little sewerage or electricity infrastructure outside of Kabul. ${ }^{4}$ Recorded acts of violence increased exponentially, from an average of 900 a year between 2002 and 2004, to 8,950 a year by 2008. ${ }^{5}$ This violence at least partly reflected the regrouping and growth of the Taliban after their earlier dispersal. As a consequence of the Taliban's intimidating presence, only a third of schoolchildren in Afghanistan's southern provinces entered schools for food aid. ${ }^{6}$ When the majority of US officials and soldiers withdrew from the country in 2014 , they left a volatile and fragmented political environment in their wake, much as the British and Soviets had done before them. This was despite more than a decade of US nation-building efforts in Afghanistan.

Nation-building in Afghanistan reached its zenith, in terms of funding and attention, toward the end of the Bush Administration's second term in office, but it was a stated objective much earlier than this. Bush himself, who had derided the concept during his Presidential campaign, came to accept it as a part of the mission in Afghanistan from April 2002 onward. Nation-building, both as a concept

2 Carlotta Gall, "Hunger and Food Prices Push Afghanistan to the Brink", New York Times, May 16, 2008.

3 Robert Crews and Amin Tarzi (eds), The Taliban and the Crisis of Afghanistan (Cambridge: Harvard University Press, 2008), 345.

4 Michael O'Hanlon and Hassina Sherjan, Toughing it Out in Afghanistan (Washington DC: Brookings University Press, 2010).

5 Committee on Armed Services, Assessment of Security and Stability in Afghanistan and Development in US Strategy and Operations (House of Representatives, One Hundred Tenth Congress, January 23 2008); Gilles Dorronsoro, Revolution Unending: Afghanistan 1979 to the Present (New York: Columbia University Press, 2005), 342.

6 Alastair Scrutton, "Attacks on Aid Challenge Afghan Reconstruction", Reuters, September 18, 2008. 
and a practice, is mired in controversy and ambiguity. Some scholars regard its contemporary uses in places such as Afghanistan as little more than an ideological veil for US imperial ambitions. ${ }^{7}$ For others who subscribe to the alleged benefits of nation-building, it is a normative concept that refers to 'the use of armed force in the aftermath of a conflict to underpin an enduring transition to democracy'. For many it is simply a synonym for a cluster of related concepts such as 'nationbuilding', 'peace-building', and 'post-conflict operations', yet others consider each of these activities to be distinct. The pros and cons of these various uses of nation-building and cognate terms will be explored in Chapter 1. For now, nation-building will simply be defined as a set of processes through which a foreign power or powers, by direct intervention and in collaboration with favoured domestic political elites, seek to erect or re-erect a country-wide institutional and material infrastructure that can become the enduring foundation of political stability after a period of armed conflict and civil strife. Hence, nation-building involves a complex of issues including security and pacification, infrastructure development and humanitarian relief, and governance and law and order. Crucially, it can also involve, as it did in Afghanistan, an ideological project to win the active support or tacit consent of the local population for the new or restructured state - what has often been euphemistically labelled as the 'winning of hearts and minds'. Understood as such, nation-building is always confronted with a unique set of problems and obstacles, arising from the historical specificity of the country in which such projects are pursued.

But the complex requirements of nation-building were neglected and the responsibilities of each US agency, and indeed official, remained undefined or ambiguous. The way in which the activity was approach by the US government also revealed a deep ambivalence at the heart of the foreign policy bureaucracy. With this in mind, the main objective of the current study is to contribute to deepening our understanding of the impact of bureaucratic politics on nation-building in Afghanistan, which clearly has implications for similar interventions elsewhere. The central research question is: Why, and how, did bureaucratic politics contribute to the failings of US nation-building efforts in Afghanistan? However, the subject must first be contextualized.

\section{Current Literature on Nation-Building in Afghanistan}

Disorder within the US foreign policy bureaucracy was certainly not the cause of nation-building failure; it was one factor among many. Bureaucratic conflict was

7 Andrew Bacevich, Washington Rules: America's Path to Permanent War (New York: Metropolitan books, 2010); Andrew Bacevich, The New American Militarism (New York: Oxford University Press, 2005); Chalmers Johnson, The Sorrows of Empire: Militarism, Secrecy and the End of the Republic (New York: Metropolitan Books, 2004).

8 James Dobbins et al., The Beginners Guide to Nation-Building (Santa Monica: RAND Corporation, 2007). 


\section{Introduction}

complicated, exacerbated and sometimes even caused by a raft of other issues. These issues include the Bush Administration's approach toward the War on Terror; the invasion of Iraq; a failure to consider the regional consequences of intervention in Afghanistan; fractures within the international nation-building effort; an imbalance of power between the US military and civilian realms; strategic ambiguity; the controversial relationship between nation-building and counterinsurgency, and Afghanistan's historical and cultural nuances.

Scholars such as Daalder and Lindsay argue that the 'Bush revolution in foreign policy' was cloaked in a doctrine of preemption, which required an 'America unbound' to forcefully reshape the international system by aggressively searching for monsters to destroy. ${ }^{9}$ Although this attitude prevailed within the Bush Administration before 9/11, the Global War on Terror (GWOT) invigorated and legitimized foreign policy based on the unilateral projection of military power. For the remainder of Bush's time in office, the GWOT superseded all other foreign policy matters. The attitude of the White House during this period has been described as a combination of arrogance and ignorance. ${ }^{10}$ President Bush has been derided for lacking sufficient knowledge of international relations and an understanding of the nuances of global politics. Some observers considered the Bush Administration to be no more than a 'callow instrument of neoconservative ideologies', but this is disputable. 'Assertive nationalists', such as Vice President Dick Cheney and Secretary of Defence Donald Rumsfeld, (at least initially) dismissed the neoconservative camp's conviction that it was in the national interest to aggressively encourage authoritarian states to become US-style democracies. However, as Epstein notes, what both factions had in common was faith that military force should unequivocally be used to destroy the enemies of the United States. ${ }^{11}$ Buttressed by this common belief, and with the help of a compliant President, Bush's inner circle constructed an overarching strategy that convinced, some would say exploited, the US public to support their foreign policy ideology. ${ }^{12}$ This came to be known as the Bush Doctrine, which was evoked to justify regime change through armed conquest. During the Bush epoch, more than any other period in history, the United States was characterized as an imperialist power. ${ }^{13}$ The ambitions of the Bush Administration left no room for a White House role in instigating a whole-of-government response to the mission in Afghanistan. This allowed the US bureaucracy to run its own race and little effort was made by the White House to mitigate bureaucratic conflict until near the end of Bush's second term

9 Ivo Daalder and James Lindsay, America Unbound: The Bush Revolution in Foreign Policy (New Jersey: Wiley, 2005).

10 Ahmed Rashid, Descent into Chaos: The United States and the Failure of Nation-Building in Pakistan, Afghanistan and Central Asia (New York: Penguin, 2008), xlii.

11 Jason Epstein, "Leviathan", New York Review of Books, May 1, 2003, 12. Joshua Marshal, "Remaking the World: Bush and the Neoconservatives", Foreign Affairs, 82:6 (2003).

12 Scott A. Bonn, Mass Deception: Moral Panic and the US War on Iraq (Piscataway: Rutgers University Press, 2010).

13 Rodrigue Tremblay, The New American Empire: Causes and Consequences for the United States and for the World (Haverford: Infinity, 2004). 
as the conflict with the Taliban-led insurgency intensified. ${ }^{14}$ Strachan claims that militarizing nation-building should be attributed to the vague policy mandate that emanated from the White House. The Bush Administration failed to establish 'a tangible link between the policy of its administration and the operational designs of its armed forces'. ${ }^{15}$ Without effective guidance counter-insurgency increased policy incoherence, which stoked the flames of bureaucratic conflict.

The US Congress and public's hunger for retribution enabled the Bush Administration to broaden the GWOT from a fight against Al Qaeda to incorporate an 'axis of evil' consisting of Iraq, Iran and North Korea. Creating this troika has been argued as representing a veil that allowed the White House to pursue particular commercial interests; increase US prestige and power in the Middle-East; and reinforce its alliance with Israel. ${ }^{16}$ These goals would be realized only through an invasion of Iraq, an undertaking that eclipsed nation-building in Afghanistan. For White House officials such as Paul Wolfowitz, the Undersecretary of Defence, the GWOT's first battleground was simply a side-show to be disregarded in favour of the moral and material rewards that the removal of Saddam Hussein promised. This resulted in a lack of resources, attention or direction toward the US mission in Afghanistan in the first few years after the fall of the Taliban. Nation-building in Afghanistan, Jones observes, was 'hamstrung by the US focus on Iraq' $\cdot{ }^{17}$ Neglect in the early stages of the nation-building project, if it could even be defined as such in the first few years, also resulted in unclear goals and responsibilities between the US agencies and officials involved.

Another factor that impacted on the scope and shape of the mission in Afghanistan was the way in which the US approached Pakistan. Before and after the invasion, the Taliban and Al Qaeda were able to travel between Afghanistan and Pakistan with relative impunity, via the notorious Pashtun tribal belt. According to Rashid 'the region had to be seen as a single entity', as the countries within were plagued by many of the same problems. But conducting nation-building in Afghanistan alone, he maintains, simply pushed these problems into neighbouring states. ${ }^{18}$ The US failed to pressure the autocratic regimes that littered Central Asia to instigate reforms. In particular, embracing and legitimizing Pervez Musharraf, Pakistan's General-Dictator, only sowed seeds of animosity toward US intervention in the country's affairs among the populace. This, in turn, prevented Pakistani citizens from resisting the Taliban and other extremists as they

14 Douglas Porch, Counter-Insurgency: Exposing the Myths of the New Way of War (New York: Cambridge University Press, 2013).

15 Hew Strachan, "The Lost Meaning of Strategy", Survival: Global Politics and Strategy, 47:3, 33-54.

16 Bruce Cummings, Ervand Abrahamian and Moshe Maoz, Inventing the Axis of Evil; The Truth about Iran, North Korea and Syria (New York: New Press: 2004); Stephen Sniegoski, Transparent Cabal: The Neo-Conservative Agenda, War in the Middle East and the National Interest of Israel (Virginia: Enigma, 2008).

17 Seth Jones, In the Graveyard of Empires: America's War in Afghanistan (New York: W. W. Norton \& Company, 2010), xxii.

18 Rashid, Descent into Chaos, xliv. 


\section{Introduction}

forcefully infiltrated society. In the absence of any nation-building or democratization framework for the region, therefore, Pakistan remained 'an open back door' that functioned as a safe haven for the Taliban. ${ }^{19}$

Priest and Feith have exposed the way in which the Bush Administration's conduct of the War on Terror precipitated a greater power imbalance between the military and the civilian branches of the US government. The Pentagon dominated foreign policy while the State Department, USAID and others were marginalized. Relationships with authoritarian states came to be defined by how they could accommodate US military interests, which undermined the State Department's diplomatic mandate. ${ }^{20}$ Yet the one element of the military that had experience with nation-building, Army Civil Affairs Units, were neglected and even downgraded. Their capacity to drive development in Afghanistan, therefore, was never realized. ${ }^{21}$

An emphasis on unilateral military power also trumped any adherence to international law or respect for international institutions. US allies, meanwhile, were often perceived by the Bush Administration to be impediments that hamstrung the capacity of the US to act decisively. Cooperation with NATO and the United Nations toward nation-building objectives was neglected in both Afghanistan and Iraq. In the case of the latter a 'coalition of the willing' was created that marched to the drumbeat of US interests, rather than a truly collaborative partnership. ${ }^{22}$ Although there was a more genuine multilateral component to the mission in Afghanistan, the US still refused to seriously consider the opinions of its allies. Cleavages within the international alliance circumscribed many nation-building goals and projects. ${ }^{23}$ While some NATO countries criticized the US for an unwillingness to spearhead a multilateral effort, conversely the United States was angered by the failure of many of their allies to effectively combat the Taliban-led insurgency. As the violence escalated in Afghanistan from 2005 onwards, many European troops remained locked within Forward Operating Bases, due to their governments' reluctance to risk casualties that would be unpopular domestically. The US, British and Canadian military described soldiers from other NATO countries 'as pot plants . . . of ornamental use only'. ${ }^{24}$

19 David Loyn, In Afghanistan: Two Hundred Years of British, Russian and American Occupation (New York: Palgrave Macmillan, 2009), 7.

20 Dana Priest, The Mission: Waging War and Keeping Peace with America's Military (New York: W.W. Norton, 2003); Douglas Feith, War and Decision: Inside the Pentagon at the Dawn of the War on Terrorism (New York: Harper, 2008).

21 Mark Benjamin and Barbara Slavin, "Ghost Soldiers: The Pentagon's Decade-Long Struggle to Win Hearts and Minds through Civil Affairs", The Center for Public Integrity, February 6, 2011.

22 Ewen Macaskill, "US Claims 45 Nations in 'Coalition of Willing",, The Guardian, Wednesday, March 19, 2003.

23 Sten Rynning, NATO in Afghanistan: The Liberal Disconnect (Stanford: Stanford University Press, 2012); David Auerswald and Stephen Saideman, NATO in Afghanistan: Fighting Together, Fighting Alone (Princeton: Princeton University Press, 2014).

24 Loyn, In Afghanistan, 8; Jones, In the Graveyard of Empires, xxiv. 
The ambiguous nature of the nation-building enterprise was representative of a lack of commitment, poor policy decisions and an inappropriate allocation of resources. There was also a broad failure to recognize the realities of Afghanistan and to translate rhetoric into action. ${ }^{25}$ This had far-reaching consequences and previous studies have acknowledged, to varying degrees, the US's incapacity to mobilize its vast resources to promote good governance, provide security or develop infrastructure. ${ }^{26}$ 'Good governance' was a policy that was never truly manifested in practice, and instead toxic corruption spread throughout the Afghan State. Empowering a centralized government proved to be 'highly corrosive' as it nurtured a crooked and impotent regime, led by Hamid Karzai, which neglected representative governance at a regional and local level, and contributed to, rather than deterred, civil unrest. All levels of government, however, failed to correctly manage resources or effectively implement policies. Consequently, politics was dominated by individuals who were willing to rent themselves out to the highest bidder. $^{27}$

Efforts to promote security fared no better. Disarmament was not prioritized, which determined that militias emerged through the country to fill the vacuum of security left by the removal of the Taliban regime. Afghanistan's security forces were unable to protect rural villagers. Insecurity was endemic to rural areas, which explains, to some extent, why the Taliban was often greeted as a force of order and stability, rather than with hostility. ${ }^{28}$ Meanwhile, on the development front, corporate contractors were foolishly employed over experienced international and local NGOs. ${ }^{29}$ These contractors, in turn, hired mercenaries to protect their projects, a militarization of development that was not well received by the local population or the international aid community. ${ }^{30}$ In particular, when a deluge of aid was triggered by the emergence of a violent insurgency, quantity trumped quality.

The Taliban were misrepresented and misunderstood by the United States and its allies. After the invasion, the Taliban was not defeated, it had merely deflated. As late as 2005, the US military estimated there were less than 1,000 Taliban fighters left in Afghanistan. US military commander Major General Eric Olson,

25 Edward Girardet, Killing the Cranes: A Reporter's Journey Through Three Decades of War in Afghanistan (Chelsea Green, 2011), 382.

26 Bing West, The Wrong War: Grit, Strategy, and the Way Out of Afghanistan (New York: Random House, 2011); David Kilcullen, The Accidental Guerrilla: Fighting Small Wars in the Midst of a Big One (New York: Oxford University Press, 2009); Brian Glyn Williams, Afghanistan Declassified, A Guide to America's Longest War (Philadelphia: University of Pennsylvania Press, 2012).

27 Girardet, Killing the Cranes, 384-388; Nick Mills, Karzai: The Failing US Intervention and the Struggle for Afghanistan (New Jersey: John Wiley \& Sons, 2011).

28 Carlotta Gall, The Wrong Enemy: America in Afghanistan, 2001-2014 (New York: Houghton Mifflin, 2014).

29 Jacob E. Jankowski, Corruption, Contractors and Warlords in Afghanistan (New York: Nova, 2011).

30 Antonio Giustozzi, "Privatizing War and Security in Afghanistan: Future or Dead End?", Economics of Peace and Security Journal, 1:2 (2007). 


\section{Introduction}

described them as 'a force in decline'. ${ }^{31}$ The Taliban, however, had reorganized and rebranded itself to ignite a protracted insurgency from late 2002 onwards. ${ }^{32}$ Furthermore, the idea that the Taliban was simply a ruthless terrorist organization, bereft of a tangible purpose besides suppressing the populace, was a misconception that was perpetuated by the Bush Administration's conception of the GWOT. The fact that the Taliban was essentially a domestic movement and many Afghans saw them as 'the cleansers of a social and political system gone wrong in Afghanistan, and an Islamic way of life that had been compromised by corruption and infidelity', was not recognized..$^{33}$

Underpinning many of these issues was Afghanistan's history and culture. A rich body of literature exposes the difficulties this presented for nation-building and that the country's environmental nuances was something that the United States failed to adequately consider. The Afghani people's notorious animosity toward foreigners; the fragility and ambiguity of the state structure; an absence of the human capital required for effective governance; and complex ethnic divisions posed a myriad of problems for any would-be nation-builder. ${ }^{34}$ Yet there seemed to be little acknowledgement or understanding from the US and its allies that they were attempting to impose democracy on a country that has been described as the graveyard of empires. ${ }^{35}$

\section{Nation-Building and Bureaucratic Politics in Afghanistan}

The role of and divisions within the US foreign policy bureaucracy have been relatively understudied compared with the other issues outlined above. The current study addresses this deficit by illuminating the role that distinctive elements within the US bureaucracy played in producing policy preferences and decisions, and in determining how they were or were not implemented. Assessing US nationbuilding in Afghanistan on this basis provides an 'alternative pair of spectacles' that 'highlights features that might otherwise be overlooked' ${ }^{36}$ In particular, it highlights what Max Weber's famous study of bureaucracy had highlighted for an earlier generation of social scientists, and which still has contemporary relevance: that the hierarchical distribution of power, authority and specialized knowledge within modern, large-scale bureaucratic organizations frequently comes at

31 Eric Olson, quoted in Tim McGirk, "The Taliban on the Run", Time, March 28, 2005.

32 Antonio Giustozzi, Koran, Kalashnikov, and Laptop: The Neo-Taliban Insurgency in Afghanistan (New York: Columbia University, 2008), 1-8.

33 Jones, In the Graveyard of Empires, xxix.

34 Ivan Arreguin-Tofy, "The Meaning of 'State Failure': Public Service, Public Servants, and the Contemporary Afghan State”, International Area Studies Review, 15:3 (2012), 263-278.

35 William Maley, The Afghanistan Wars (New York: Palgrave Macmillan, 2009); Paul Fitzgerald and Elizabeth Gould, Invisible History: Afghanistan's Untold Story (San Francisco: City Light Books, 2009).

36 Graham Allison and Philip Zelikow, Essence of Decision: Explaining the Cuban Missile Crisis (New York: Longman, 1999), 255. 
a price. ${ }^{37}$ That price includes the inflexibility of bureaucratic rationality and the congealing of bureaucratic interests within subsections of a larger organizational whole. This can and frequently does have unintended consequences that impede or preclude the bureaucracy from efficiently fulfilling the functions for which it was developed in the first place.

Classic studies on foreign policy bureaucracy are agreed that bureaucratic forces are diverse and extremely resilient. ${ }^{38}$ The US foreign policy system 'is one in which power is disbursed among a wide variety of organisations and individuals'. As the agencies that make up the US foreign policy apparatus are large, relatively autonomous creatures, it is difficult for them to achieve policy coherence on any given issue. Consequently, US foreign policy has 'become increasingly political and cumbersome with the growth of bureaucracy'. ${ }^{39}$ These characteristics are all the more problematic when the US engages in nation-building. Oye has convincingly argued that a complex endeavour that involves multiple parties 'militates against identification and realisation of common interests' ${ }^{40}$ In reference to nation-building in Afghanistan this was certainly true, as we will see, and a coherent whole-of-government response proved to be elusive.

Effective nation-building lay well beyond the comfort zone of the US foreign policy bureaucracy. None of the three key agencies that were involved - the Department of State, USAID and the Department of Defence - proved themselves capable of taking on an effective leadership role that could overcome bureaucratic divisions. Thus competing and conflicting spheres of influence arose and consolidated so that a variety of factions jockeyed for power. In particular, during the implementation stage US officials tended to act in accordance with beliefs about their own agency's interests and expectations, rather than the necessities of nation-building. In other words, the requirements of nation-building, and how these requirements were to be understood, were very much shaped by an agency's position within the bureaucratic structure. This was further complicated by rifts within the agencies themselves and the gulf of understanding between actors in Washington and those in the field. ${ }^{41}$

With this in mind, the collective behaviour of US foreign policy agencies, and the individuals who sit within them, can be best understood through the lens of four distinctive but interconnected variables: interests, perception, culture and

37 Max Weber, The Theory of Social and Economic Organization (New York: The Free Press, 1964).

38 I.M. Destler, Presidents, Bureaucrats and Foreign Policy: The Politics of Organizational Reform (Princeton: Princeton University Press, 2015); Morton Halperin and Priscilla Clapp, with Arnold Kanter, Bureaucratic Politics and Foreign Policy (Washington DC: The Brookings Institution, 2006); James Q. Wilson, Bureaucracy, What Government Agencies Do and Why They Do It (New York: Basic Books, 1989).

39 Garry Clifford, "Bureaucratic politics", in Michael Hogan and Thomas Paterson, Explaining the History of American Foreign Relations (New York: Cambridge University Press, 2004), 92

40 Kenneth Oye, "Cooperation Under Anarchy: Hypothesis and Strategies", in Oye (ed), Cooperation Under Anarchy (Princeton: Princeton University Press, 1986), 19.

41 'The field' refers to Afghanistan. 
power. Firstly, interests refer to what is, or what is believed to be, beneficial or detrimental to an agency as a discrete organization. This encompasses tangible, material considerations such as human resourcing, government funding and the agency's expenditure, but also more nebulous considerations such as an agency's prestige and status relative to other agencies. Secondly, and closely bound up with interests, is an organization's perception of a given set of problems, and its perception of the merits and demerits of possible solutions to those problems. Perception is influenced by both the form and function of a given organization. To paraphrase the old adage, 'where you stand on particular issues depends on where you sit at the decision-making table'.

Thirdly, perception is shaped by and is an aspect of an agency's relatively distinctive culture. Culture here is understood in the dominant anthropological sense of the word, as a shared set of beliefs and practices within a given human group, that predispose members of that group to think and act in ways that conform to dominant group patterns. This does not mean that thinking and acting are determined with mechanical necessity, or that individuals within an organization are unable to apply their own logic and rationality in arriving at positions that differ from those of the organization as a whole. But it does mean that such individual rationality is constrained by the broader, organizational culture in which they are socialized over time, and which sanctions particular beliefs, routines and procedures. Much of this operates at the level of unconscious cognition, and is therefore very resilient over time. Finally, interests, perception and culture all evolve and operate within a broader matrix of power. Power is here understood in the traditional Weberian sense as, "the probability that one actor within a social relationship will be in a position to carry out his own will despite resistance, regardless of the basis on which this probability rests'. ${ }^{42}$ The 'actor' can be an individual or a collective such as a bureaucratic agency, and the successful deployment of power can be based on either compulsion or persuasion, hard or soft power. Taken together, these four variables provide a powerful lens with which to examine the divisions both between and within US foreign policy agencies, which were so important in shaping nation-building outcomes in Afghanistan.

While bureaucratic division and conflict sit at the centre of this study, there are additional themes. Connected to bureaucratic problems are the broader political mistakes made by the United States government in its approach to Afghanistan, and a profound inconsistency between its expressed rhetorical ambitions on the one hand, and a failure to understand the practical realities of nation-building on the other. At a more general level, the study also makes a contribution to the vexed question of whether or not the US should engage in nation-building at all, and if so under what conditions.

But there are also limits and it is important to clearly state them from the outset. The regional and global dimensions of US foreign policy, for example, are

42 Max Weber, Economy and Society: An Outline of Interpretive Sociology (Berkeley: University of California Press, 1978), 53. 
not central considerations. They are only dealt with in so far as is necessary to illuminate some key points about the US intervention into Afghanistan. In addition, although there are obvious parallels between the case of Afghanistan and US nation-building activities in Iraq, these are not systematically addressed due to space limitations. The important role played by non-government organizations (NGOs) are also largely absent, as are some issues that, prima facie, might also seem to warrant inclusion in a discussion of nation-building in Afghanistan. These include such important issues as refugees, disarmament and US military operations. Finally, many individuals and government factions are involved in Afghanistan. Due to the sheer scale of the task, a totalising account of the machinations of the US foreign policy bureaucracy in Afghanistan, to say nothing of the Afghani government, is impossible. The study instead concentrates on the most relevant issues and examples.

\section{Method and Structure}

In terms of primary research, the author conducted a number of comprehensive interviews with high-ranking US officials both in Washington and via correspondence. The interviews revealed interests, loyalties, frustrations and many unique events and experiences not yet in the public realm. Experiencing bureaucratic problems was common, as was the acknowledgement that parochial boundaries existed between and within agencies. Depending on where the interviewees 'stood and sat', opinions were often dramatically different. Primary sources also included congressional hearings, which comprised a variety of testimonies from agencies and individuals in Afghanistan. Contemporary media coverage that involved the opinions of high-ranking officials, soldiers and civilians, was also an important source of information, as were government reports that addressed agency behaviour and capacity. In terms of the secondary literature, the study utilizes many first-hand accounts of nation-building in Afghanistan published as books, biographies and memoirs of high-ranking officials, as well as the more analytical political science literature on nation-building, bureaucratic politics and foreign policy.

The remainder of the book is divided into three parts and a conclusion. Part I reviews the relevant literature, connects bureaucratic politics to nation-building, and provides a summary of the history of the Afghan State. Part II focuses on the bureaucratic dimensions of US nation-building in Afghanistan. Part III examines efforts to promote intragovernmental cooperation toward that end. The conclusion draws the threads of my argument together and discusses the broader analytical and political implications of the study.

Part I is composed of two chapters. Chapter 2 begins by discussing the ambi-

guity that surrounds 'nation-building' and its cognate terms, and justifies my own position on this analytical and political vocabulary. It also assesses how the United States has interpreted and approached nation-building in the past and into the present. It continues by providing something of a brief history of the Afghan State, in order to illuminate previous attempts at nation-building in that 


\section{Introduction}

country and the resistance that such attempts elicited. Chapter 3 continues the review of the relevant literature, but focuses more specifically on the link between bureaucratic politics and US foreign policy. It includes a review and critique of the rational actor model, according to which states have relatively homogeneous and identifiable interests. In this view, states are rational actors as much as the particular personalities who do their bidding - a proposition that is, in the case of nation-building in Afghanistan, clearly erroneous. On the back of that critique the chapter creates a new bureaucratic politics model, centred around the proposition that agency interests, perceptions, culture and power shape and constrain interand intra-agency behaviour, often rendering it irrational in terms of effectively achieving stated goals such as those bound up with nation-building.

Chapter 4 is the first of four chapters that make up Part II. The chapter argues that nation-building in Afghanistan was particularly vulnerable to intergovernmental conflict. It illustrates this by exploring the interaction between the Department of Defence, the Department of State, USAID and the CounterBureaucracy. ${ }^{43}$ This reveals broad currents of discord, but also that a more detailed examination of intragovernmental conflict in Afghanistan is necessary. With this in mind, Chapters 5, 6 and 7 form something of a trio. Each deals with a specific nation-building issue to assess how contrasting interests, perceptions, cultures, and power, between and within agencies, impacted upon policy decisions and implementation. A diverse selection of policies, projects and initiatives is subject to examination, in order to discern the part played by each agency, and to identify the circumstances under which relations within and between agencies changed from one issue to another.

Chapter 5 focuses on security. It provides a detailed account of the competing policies between the State Department and the Military Establishment. It is particularly concerned with how this division played out with respect to the International Security Assistance Force (ISAF), the CIA's interest in supporting Afghanistan warlords, and US involvement with Afghanistan's security forces. Chapter 6 shifts to infrastructure development. The approach of the Pentagon, State Department, USAID and the Counter Bureaucracy are compared and contrasted, and specific road-building, agriculture and education projects are examined. This again reveals deep divisions within the foreign policy bureaucracy overall. Chapter 7 concentrates on law and governance. The US counter-narcotics strategy, the US relationship with the Karzai government and US efforts to construct Afghanistan's legal system are explored.

Part III addresses mechanisms that may have produced a whole-of-government approach. Chapter 8 reviews the instruments that were created by the US government to promote cooperation, and compares them with those advocated by think tanks and academics. It is argued that it was extremely difficult for any of these

43 The Military Establishment and Counter-Bureaucracy are used as umbrella terms. The military establishment includes the Defence Department and the United States Armed Forces whilst the Counter-Bureaucracy encompasses Washington's regulatory and oversight bodies. 
initiatives to surmount embedded bureaucratic hurdles or to overcome entrenched agency interests. Chapter 9 conducts a detailed analysis of the Provincial Reconstruction Teams that operated in Afghanistan. These can be understood as microcosms of the greater US nation-building effort.

Chapter 10 draws together the principal findings from the research. It reemphasizes the discovery that bureaucratic divisions were not only extremely important in Afghanistan, but that they provide one of the principal keys to unlocking the riddle of US nation-building failure. 



\section{Part I}

\section{Background and Methodology}





\section{Nation-Building and the Afghan State}

The US's military occupation of Afghanistan, and its subsequent efforts to stabilize the country and promote its political and economic development in a direction satisfactory to the US, came in the immediate wake of similar operations in Somalia, Bosnia and Kosovo in the 1990s. ${ }^{1}$ Although the scale and the nature of these operations had major differences, they shared a pattern of family resemblance that led many commentators to discuss them under the common mantle of 'nation-building'. Indeed, through the 1990s and into the 2000s a fierce debate raged within US foreign policy and academic circles about just what constituted nation-building, and whether or not the US should engage in such activities. ${ }^{2}$

Political conservatives typically derided these projects as international social work, condemning the use of the US military to do things other than 'kill people and smash things', as Colonel Fred Peck colourfully put it. ${ }^{3}$ At the other end of the political spectrum, scholars more critical of US foreign policy motives similarly condemned nation-building, but for very different reasons. They suggested that US nation-building efforts masqueraded under false pretences, serving as rhetorical cover for what were in fact US imperial ambitions. ${ }^{4}$ On the continuum

1 James Dobbins, “America's Role in Nation-Building: From Germany to Iraq", Survival, 45:4 (2003), 87-110; Paul Miller, Armed State Building: Confronting State Failure 1898-2012 (Cornell: Cornell University Press, 2013); Michael Ignatieff, Empire Lite: Nation-building in Bosnia, Kosovo and Afghanistan (London: Vintage, 2003).

2 Karin von Hippel, "Democracy by Force: A Renewed Commitment to Nation-Building", The Washington Quarterly, 23:1 (2000), 95-112, Marina Ottaway, "Building", Foreign Policy, 132 (2002), 16-24; Francis Fukuyama, "Nation-Building 101”, The Atlantic Monthly, January-February (2004), 159-162; Gary Dempsey, "Old Folly in a New Disguise: Nation-building to Combat Terrorism", Policy Analysis, Report 429, (2002), 1-22; Noah Feldman, What We Owe Iraq: War and Ethics of Nation-Building (Princeton: Princeton University Press, 2006); Mark Berger, "From Nation-Building to State-Building: The Geo-Politics of Development, the Nation-state System and the Changing Global Order", Third World Quarterly, 27:1 (2006), 5-25.

3 Carolyn Stephenson, "Nation-Building", Beyond Intractability, January 2005. http://www.beyond intractability.org/essay/nation-building (accessed 13/1/2011).

4 Stephen Kinzer, Overthrow: America's Century of Regime Change from Hawaii to Iraq (New York: Times Books, 2010); Tariq Ali, Bush in Babylon: The Recolonization of Iraq (London: Verso, 2004); Chalmers Johnson, Dismantling the Empire: America's Last Best Hope (New York: Metropolitan 
between these two poles emerged a variety of positions with differing perspectives on the meaning of nation-building, whether or not it could succeed through external intervention and, if it could, would this be best served by unilateral or multilateral intervention. ${ }^{5}$ What role the military would or should play in all of this was perhaps the most vexing question of all. It is not the purpose of this chapter to canvass all of these positions or to provide comprehensive answers to the many questions they raise. This would take us too far afield from our main focus, which is Afghanistan. It is necessary, however, to directly address some of the conceptual ambiguities that have plagued the field, and to define the way in which this study intends to use the term 'nation-building'.

With this in mind, the chapter begins with a consideration of some of the conceptual confusion that has bedevilled the literature on nation-building and its cognate terms - discussing the historical milieu out of which such confusion emerged before arriving at a definition. It continues with a more concrete discussion of the types of activities and goals that are typically associated with nation-building, examining these in the context of US nation-building efforts since the Second World War. This provides the necessary background for a brief historical overview of the history of the Afghan State, from its inception in 1747 until the USled invasion in 2001. This overview highlights key elements that have shaped Afghanistan's political environment, examines the British and Soviet occupations, and discusses developments in areas such as governance, economic development and security.

\section{What is Nation-Building?}

Paradoxically, a degree of consensus in regard to what nation-building requires stands in stark contrast to the ambiguity surrounding the term itself. Chesterman correctly notes that "the term "nation-building" . . is a broad, vague, and often pejorative one'. It is frequently used interchangeably with other phrases such as 'state-building', 'peace-building' and 'stabilization and reconstruction operations'. In particular, nation-building is often conflated with state-building, and simply means the enhancement of a state's capacities, with or without external intervention. For this reason, Chesterman prefers 'state-building' as the more accurate term for those activities usually brought under the rubric of nation-building: 'The focus here is on the state (that is, the highest institutions of governance in

Books, 2010); Andrew Bacevich, American Empire: The Realities and Consequences of US Diplomacy (Cambridge: Harvard University Press, 2003); Andrew Bacevich (ed.), The Imperial Tense: Prospects and Problems of American Empire (Chicago: Ivan R. Dee, 2003).

5 James Dobbins et al., America's Role In Nation-Building: From Germany to Iraq (New York: RAND, 2003); Francis Fukuyama (ed.), Nation-Building: Beyond Afghanistan and Iraq (Baltimore: John Hopkins University Press, 2006); Kate Jenkins and William Plowden, Governance and Nation-building: The Failure of International Intervention (Cheltenham: Edward Elgar, 2006); Minxin Pei and Sara Kasper, "Lessons from the Past: The American Record on Nation Building" (Washington DC: Carnegie Endowment for International Peace, 2003). 
a territory) rather than the nation (a people who share common customs, origins, history, and frequently language)'. ${ }^{6}$ It is thus helpful to reconsider the origins of 'nation-building' and the historical milieu out of which it emerged, in order to untangle these various strands of its usage.

The contemporary notion of nation-building can be traced back to the decades after the Second World War. Although there had been earlier iterations of the term to describe, for example, the political projects of elites in nineteenth-century Germany, Italy, Japan and the United States, which sought to make political boundaries congruent with cultural identity while modernizing and integrating the political-economy of these new national states ${ }^{7}$ - it was global political developments after the Second World War that brought 'nation-building' into the lexicon of both academics and popular audiences. The immediate source of this development had two key aspects.

The first of these was the decolonization of vast areas of Africa and Asia, which presented newly independent states with a number of key problems to which nation-building was thought to be a solution. Among other things, these problems included the lack of a unifying national identity, economic under-development, the fragility of political and social institutions, and the questionable legitimacy of state power. Needless to say, the specific solutions pursued for each of these problems in different national states were highly variable. But irrespective of this variability, such solutions were often understood under the rubric of nation-building, which became largely synonymous with development and modernization. ${ }^{8}$ Importantly, nation-building was here understood as largely an endogenous process, even if external powers could assist in its promotion.

The second post-war development to which the vocabulary of nation-building was a response was the US military occupation of Japan and Germany. ${ }^{9}$ The defeated axis powers had suffered tremendous physical destruction, while the political regimes that had led them into war had been decapitated. In a context of rapidly escalating bi-polar competition with the Soviet Union, the United States sought to rebuild the shattered economies of the axis powers, and to establish liberal-democratic constitutional orders that would be bulwarks against Sovietstyle communism. This was accomplished through both direct military occupation and political intervention, in addition to a massive injection of restorative financial aid under the auspices (in Europe) of the Marshal Plan. ${ }^{10}$ The subsequent

6 Simon Chesterman, You, The People; The United Nations, Transitional Administration and StateBuilding (New York: Oxford University Press, 2004), 4.

7 John Breuilly, Nationalism and the State (Manchester: Manchester University Press, 1973); Ernest Gellner, Nations and Nationalism (Oxford: Blackwell, 1983).

8 Karl Deutsch, "Nation-Building and National Development: Some Issues for Political Research", in Karl Deutsch and William Foltz (eds), Nation-building (New York: Atherton, 1963), 7-8; Reinhard Bendix, Nation-building and Citizenship: Studies of Our Changing Social Order (Berkeley: University of California Press, 1964).

9 Dobbins et al., America's Role in Nation-Building: From Germany to Iraq, 3-51.

10 Julian Zelizer, Arsenal of Democracy: The Politics of National Security - from World War II to the War on Terrorism (New York: Basic Books, 2010), 74-75; Warren Cohen, The Cambridge History 
economic recovery and relative political stability of the old axis powers, now firmly in the US Cold War camp, would later be presented as exemplary instances of nation-building, and models for what could be accomplished through external intervention into post-conflict zones such as Afghanistan. ${ }^{11}$ Such views typically ignore the obvious differences between these cases: namely, that Germany, Japan and Italy - despite massive physical damage and loss of life during the war - had highly educated and literate populations, histories of modern political institutions with sophisticated bureaucracies, and technologically advanced, industrialized economies that could be readily rebuilt given the capital and political will. They also had populations with shared language and national identities, despite regional differences. This stood in stark contrast to countries like Afghanistan, with its many ethnic and linguistic divisions, which could and frequently did become the basis for political mobilization and division.

These two sources out of which emerged a theory and practice of nationbuilding - the post-colonial state on the one hand and post-war occupation and reconstruction on the other - are important because they contain within them the seeds of difference, or at least difference of emphases, that would be elided by later theorists and commentators. The difference is two-fold. On the one hand, nation-building arising from the post-colonial experience is, in essence, an endogenous process. External actors, including other states, may assist and/or encourage nation-building in various ways, but it is understood to be a project pursued by the local population and state. Nation-building in the post-war axis states, by contrast, was exogenous because it represented projects in which US military occupation, political intervention and massive economic aid was absolutely essential. On the other hand, while nation-building arising from both sources involved the building of state capacities (perhaps more accurately labelled 'state-building', as Chesterman would insist), post-colonial nation-building was also concerned with the forging of a common identity and hence loyalty to the new state. This typically involved programmes of mass education in a common language, as well as the propagation of a nationalist spirit through state media, flags, anthems, national holidays, memorials and the like. As well as state capacities, what was being 'built' here was very much a 'nation' in the strict sociological sense - a named population sharing a contiguous territory and a common language and identity. ${ }^{12}$

Subsequent US nation-building efforts in Vietnam, Kosovo, Bosnia, Haiti, the Democratic Republic of Congo, Iraq, Afghanistan and elsewhere, have involved varying degrees of both state and nation-building, although nation-building has

of American Foreign Relations, Volume IV: America in the Age of Soviet Power 1945-1991 (Cambridge: Cambridge University Press, 1993), 35-44.

11 James Surowiecki, "The Marshall Plan Myth", The New Yorker, December, 2001, http://www. newyorker.com/archive/2001/12/10/011210ta_talk_surowiecki (accessed 3/9/2009).

12 Benedict Anderson, Imagined Communities: Reflections on the Origins and Spread of Nationalism (London: Verso, 1991), 1-9; Gellner, Nations and Nationalism, 1-5; Anthony Smith. Nationalism: Theory, Ideology, History (Cambridge: Polity Press, 2001), 5-9. 
been the more common vernacular used to describe these projects. ${ }^{13}$ With respect to South Vietnam, James Carter describes how the US was involved in a comprehensive effort to create a functioning state and a common anti-communist national identity from 1954. ${ }^{14}$ This involved propping up the Diem regime with massive financial, political and ultimately military support, in a quest to extend the reach of his regime over every square inch of territory south of the 17th parallel. The military coup against the Diem government in November 1963, and the fullscale US military intervention from March 1965, did not mean the end of nationbuilding in South Vietnam; it simply changed its form. The US Marine Corp's 'Combined Action Program' (CAP), for example, sent teams into South Vietnamese villages to undertake development projects and train local militias. The Civil Operations and Revolutionary Development Support Program (CORDS) similarly combined military and civilian personnel and resources to launch a number of projects that can be understood as part of its nation-building efforts. ${ }^{15}$ Even the much maligned Strategic Hamlets Program -which sought to physically separate the rural population from Viet Cong influence - was, in a perverse way, an aspect of US nation-building in South Vietnam. ${ }^{16}$ But there was a disconnected strategy between 'military' and 'nation-building' elements and an inharmonious division of labour. For the most part the US military focused on the war-fighting mission, while other agencies, such as USAID and the State Department, were largely shut out. Significantly, the strengths and weaknesses of nation-building in Vietnam were, until the protracted occupations of Afghanistan and Iraq, seldom examined by US officials. Indeed, Andrew Bacevich suggests that Vietnam demonstrates that the US system provides no institutional basis from which to learn from past mistakes. This was exacerbated by the post-Vietnam attitude of US military officers who perceived nation-building 'as anathema'. ${ }^{17}$

Almost three decades later, Bosnia and Kosovo emerged as new theatres of nation-building. After the Dayton Accords in 1995 effectively brought the military aspects of the Bosnia conflict to a conclusion, Presidential Directive 56 (PDD56) called for a whole-of-government approach to nation-building. This could be achieved through inter-agency training, planning and the institutionalization of lessons learned. Moreover, debate among influential policy-making and academic circles highlighted the need for specific inter-agency teams. The Civil-Military Operations Center was created to achieve these aims. Under the title of Military Operations Other Than War (MOOTW), the US military also adopted principles that bridged combat operations and development. These acknowledged, and were a response to, the coordination challenges that needed to be addressed between

13 Miller, Armed State Building, 117-175.

14 James Carter, Inventing Vietnam: The United States and State-building, 1954-1968 (Cambridge: Cambridge University Press, 2008), 1-20.

15 Author Interview with a Senior State Department Official, Washington DC, April 30, 2012.

16 Michael Latham, Modernization as Ideology: American Social Science and "Nation-building” in the Kennedy Era (Chapel Hill: University of North Carolina Press, 2000), 151-209.

17 Andrew Bacevich, Washington Rules (New York: Metropolitan Books, 2010), 156. 


\section{Background and Methodology}

the US military and other US agencies. The US Army Peacekeeping Institute was employed to 'refine interagency coordination' ${ }^{18}$ Considering these developments, it was believed that 'peace enforcement and nation-building' would become not just 'staples of senior military leadership diet', but a whole-of-government commitment. ${ }^{19}$ Critics such as Hosmer, however, argued that without constant attention these 'insurgency assets' would atrophy. ${ }^{20}$ But his warning went unheeded. Mirroring Vietnam, the US experience of nation-building in Bosnia, and later Kosovo, had severe limitations.

There were also problems associated with military planning, force structure and doctrine. In a post-Vietnam era, these were all centred on the Soviet threat with a commitment to not 'do' counter-insurgency. But the US military's stance on nation-building was more opaque. On one side were those who wished to turn their back on a concept that they believed to be outside of the parameters of military doctrine, and on the other were those who wished to embrace nation-building as a key component of military planning. Between these two competing poles were those who believed it to be simply one part of the military's broader interest in 'warfighting'. The very same debate resonates within the corridors of the Pentagon today between various components of the military apparatus.

It is notable that by the time of the Bosnia and Kosovo conflicts in the 1990s, a variety of terms in addition to nation-building were being used to describe what the US and the broader international community were undertaking, including peace-keeping, peace enforcement and peace-building. Former UN Secretary General Boutros Boutros-Ghali referred to the latter as, 'comprehensive efforts to identify and support structures which will tend to consolidate peace and advance a sense of confidence and well-being among the people'. More recently, the Brahimi Panel re-defined peace-building as 'activities undertaken on the far side of conflict to reassemble the foundations of peace and provide the tools for building on those foundations something that is more than just the absence of war'. ${ }^{21}$ As with nation-building it includes issues such as humanitarian aid, security, law, and development. Peace-building was also a term used by the US army to describe the mission in Bosnia. But US military nomenclature at that time revealed definitional fragmentation. Most official correspondence referred to US efforts as peace-building, while the US army command hub at the Pentagon used the terms

18 Michael Hardesty and Jason Ellis, Training for Peace Operations: The US Army Adapts to the Post-Cold War World (Washington DC: United States Institute of Peace, 1997), 22.

19 Howard Olsen and John Davis, Training US Army Officers for Peace Operations: Lessons from Bosnia (Washington DC: United States Institute of Peace Press, 1999), 3.

20 Stephen Hosmer, The Army's Role in Counterinsurgency and Insurgency (Santa Monica: RAND, 1990), 28-35.

21 Boutrous Boutrous Ghali, "An Agenda For Peace”, Report of the Secretary General, A/47/277s/24111, June 17 1992, www.un-documents.net/a47-277.htm (accessed on 22/7/2010); United Nations General Assembly Security Council, Report of the Panel on United Nations Peace Operations (the Brahimi Report), August 21, 2000. 
'peacekeeping' or 'peace enforcement'. The United States European Command, meanwhile, preferred the term 'stability operations'. ${ }^{22}$

More recently in Afghanistan and Iraq, nation-building has often been rebadged under the label 'Stabilization and Reconstruction Operations' (SROs). Criticism towards nation-building was so severe towards the end of the second term of the Bush Administration that the US government decided to rebrand its ongoing activities in Afghanistan and Iraq as SROs. The United States Institute of Peace asserts that the goal of SROs was the creation of a safe and secure environment through the rule of law, stable governance and sustainable development. The US military, especially, became enamoured with the term, using it in conjunction with counter-insurgency. The change in classification was considered by some to signify 'a dramatic shift in thinking . . . from an exclusively humanitarian to a more complicated humanitarian/security perspective', thus presenting 'a more realistic conception of what was required'. ${ }^{23}$ More realistically the change in language was due to the perceived failures of 'nation-building' in the two countries. Beneath the rhetoric of a 'dramatic shift in thinking', SROs remained a synonym for nationbuilding. One member of a War Crimes Commission Hearing observed that the use of the phrase SRO 'strikes me as nation-building' and was utilized because 'we don't want to deal with the reality that we're into nation-building ... We don't describe it that way, but that's what we're doing'. ${ }^{24}$ With this in mind, it seems that in the public realm the only concrete differences between the terms nationbuilding, state-building, peace-building and SROs are who applies the term and who has the power to make their definition stick.

So where does this discussion leave us in terms of how nation-building is to be understood in this thesis? First, although what is often referred to as nationbuilding is simply the enhancement of state capacities, it is not only that. It also involves efforts to forge more cohesive national identities and loyalty to the new state, most frequently through mass education and state-sponsored propaganda campaigns, which may or may not have external support. Thus, contra Chesterman, this study employs the more encompassing 'nation-building' instead of 'state-building'. Second, whether it is principally promoted by internal or external actors, nation-building involves efforts to build country-wide material and institutional infrastructure, such that the administrative reach and political authority of the state is enhanced. Third, such projects are often pursued in the wake of armed conflict and civil strife that have severed the nexus between society and state. Finally, we can distinguish between endogenous and exogenous nation-building. The latter is principally driven by external actors who intervene directly in a state or failed state, and then embark on those state- and nation-building activities.

22 Michael Hardesty and Jason Ellis, Training for Peace Operations: The US Army.

23 Pauline Baker, "Forging a US Policy Toward Fragile States", PRISM, 1:2, 74.

24 Commission on Wartime Contracting, "An Urgent Need: Coordinating Reconstruction and Stabilization in Contingency Operations", Commission on Wartime Contracting Hearing, Washington DC, $2010,34$. 


\section{Background and Methodology}

It is this exogenous or externally sponsored nation-building that is our principal focus here.

As such, the following definition of (externally sponsored) nation-building is used: nation-building is a set of processes through which a foreign power or powers, by direct intervention and in collaboration with favoured domestic political elites, seeks to promote a particular political identity and erect or re-erect a country-wide institutional and material infrastructure that can become the enduring foundation of political stability after a period of armed conflict and civil strife. But if this is what nation-building means, what concrete activities should it involve? On this there has been more agreement in the literature than there typically has been with respect to terminology.

\section{Nation-Building Practice}

Among scholars, there is some agreement on what nation-building requires and what it involves. Firstly, it requires a lengthy commitment in terms of time, typically years or even decades rather than months. ${ }^{25}$ Secondly, with this long-term temporal commitment also comes a significant commitment of human, financial and other resources. ${ }^{26}$ Thirdly, each nation-building situation is unique. There are no strict criteria that can be abstractly applied to each case. Policy, therefore, must be shaped and adjusted to suit the concrete situation. That said, there are some general areas of agreement as to what effective nation-building demands.

In post-conflict situations nation-builders must navigate a complex and volatile environment that includes displaced persons, ethnic, tribal and religious rivalry, crime, corruption, disease, malnutrition, and humanitarian abuses. Humanitarian assistance is the most pressing initial concern. The provision of shelter, food, clothing and medical services saves lives, assists refugees and relieves suffering. Once the humanitarian situation is under control, the more difficult issues of governance, security, law and development can be prioritized..$^{27}$ Here the promotion of effective governance is essential. A transitional authority is the first step, but in the longer term international actors must facilitate the creation of an effective and viable system of governance. Perhaps the most difficult problem here concerns representation - who will be represented at the helm of the refurbished ship of state, and how will that representation be determined? Some scholars contend that, as far as is feasible, all political factions in society should be represented in

25 Roderic Alley, International Conflict and the International Community: Wars Without End? (London: Ashgate, 2004, 166); Chesterman, You, The People; The United Nations, Transitional Administration and State-Building, 235; Albert Somit and Steven Peterson, The Failure of Democratic Nation-Building: Ideology Meets Evolution (New York: Palgrave Macmillan, 2005), 46.

26 Somit and Peterson, The Failure of Democratic Nation-Building, 40; James Dobbins, Seth Jones, Keith Crane and Beth Cole DeGrasse, The Beginners Guide to Nation-Building (Santa Monica: RAND, 2007), 17; Marina Ottaway, "Rebuilding State Institutions in Collapsed States", Development and Change, 33:5 (2002), 1017.

27 Dobbins et al., The Beginners Guide to Nation-Building, 111. 
the new governing institutions. In this view, international agents must avoid creating 'closed societies and structures of power', through the exclusion of certain groups from the political process. ${ }^{28}$ The difficulty is, however, that the empowerment of some persons and factions can have a longer-term destabilizing impact on governance. As Francis Fukuyama warns, the nascent political apparatus may be born with a 'birth defect'. ${ }^{29}$

In US nation-building efforts since the Second World War, there has been a simple, some would say simplistic, answer to complex questions about representation and governance: nation-building should be tethered to democracy promotion, with democracy being rather narrowly construed to mean the emulation of US democracy and the holding of periodic elections. Indeed, some prominent voices in the debate about nation-building define it as being a project with democracy as its main objective. James Dobbins, for example, defined US nation-building as 'the use of armed force in the aftermath of a conflict to promote a transition to democracy'. ${ }^{30}$ Similarly, former Secretary of State George Shultz attached the need for US involvement in Kosovo to democracy and the goal of 'liberating a people' by supporting their 'yearning for freedom'. In Bosnia, Secretary of State Madeline Albright demanded that the Commander of the Armed Forces, Colin Powell, actively use the 'superb military' of the United States in the service of democracy, a call enthusiastically supported by right-wing hawks and jingoists. ${ }^{31}$

The tying of nation-building to democracy promotion raises two key problems. First, despite the lofty rhetoric, the history of US democracy promotion is replete with examples of democratic governance being suffocated by the US when actual or potential democratic outcomes were seen to threaten US interests. Second, democracy has usually been understood in very narrow electoral terms, with elections being viewed as a gauge of nation-building progress. Karl astutely labels this as the 'fallacy of electoralism', a misguided assumption that holding elections 'will channel political action into peaceful contests among elites, the winners of which are accorded public legitimacy'. ${ }^{32}$ Yet the reality has usually been very different, with the legitimacy of new governments in Bosnia, Kosovo, Afghanistan and Iraq being questioned from the outset by significant sections of the population over whom they ruled. For the US, then, advocating an overarching electoral democratic template represents an elegant solution to a complex set of problems that are not so easily solved. Indeed, as Paris argues, efforts to transform

28 David Beetham, The Legitimation of Power (London: Palgrave Macmillan, 1991), 90.

29 Francis Fukuyama, "Guidelines for Future Nation-builders", in Francis Fukuyama (ed). NationBuilding: Beyond Afghanistan and Iraq (Baltimore: John Hopkins Press, 2006), 237.

30 Harry Kreisler, Interview with James Dobbins, Conversations with History, Institute of International Studies, UC Berkeley, May 5, 2005.

31 Hardesty and Ellis, Training for Peace Operations: The US Army Adapts to the Post-Cold War World, 2; Michael Dobbs, "With Albright, Clinton Accepts New US Role", Washington Post, December 8th, 1996, http://www.washingtonpost.com/wp-srv/politics/govt/admin/stories/albright 120896.htm (accessed on 22/11/2010).

32 Lynn Terry, "The Hybrid Regimes of Central America", Journal of Democracy, 6:5 (1995), 73. 
war-shattered states into US-style democracies risk exacerbating, not moderating, societal conflicts. ${ }^{33}$

Culture is also an important consideration for the establishment of a new political order. Nation-builders must account for the traditions, or a plurality of traditions, that have shaped the culture of the target country. According to Somit and Peterson, there should be an 'appreciation of the culture of the target country, and avoidance of arrogance, or seeming to denigrate the institutions and values of the people'. But conversely, would-be nation-builders also need to be sensitive to the ways in which local culture can impede their efforts. In much the same way that agency culture can form a barrier to coherent US foreign policy, the cultural traditions of a country can prevent the introduction of what from the standpoint of the nation-builders seem like rational changes. ${ }^{34}$ Effective means need to be identified and developed that can help overcome these impediments without offending local cultural sensibilities.

In order for governance to be effective, there must be a stable security environment. Nation-building aims, therefore, to facilitate a transition from a 'state of internal convulsion to a settled civic order', and to achieve 'a self-sustaining peace'. For those who advocate the virtues of nation-building, the general consensus is that a vigorous security commitment is required within the first 6-12 months. In the absence of security, domestic spoilers are able to exploit a context that is ripe for violence, corruption and disorder. Allowing a security vacuum to develop, Chesterman contends, 'may irreparably undermine the larger project of consolidating a lasting peace'. ${ }^{35}$

For these reasons, US nation-building has been characterized, some would say defined, by a strong and active military presence. Notwithstanding the rhetoric about inter-agency collaboration, the US military has predominated in recent US nation-building efforts. Dempsey asserts that the strong military flavour of US nation-building makes it, 'the most intrusive form of foreign intervention there is' ${ }^{36}$ As a result, some would argue that US nation-building is always distorted, in that it relies on a set of war-making institutions to achieve peace outcomes that would more readily be achieved by civilian agencies. Moreover, improvements in the security situation within a country may be hampered by the very presence of

33 Roland Paris, "Peace Building and the Limits of Liberal Internationalism", International Security, 22:2 (1997), 57.

34 John Pulparampil, Models of Nation-building: A Critical Appraisal (New Delhi: NV Publications, 1975), 24; Somit and Peterson, The Failure of Democratic Nation-building, 40; Jenkins and Plowden, Governance and Nation-Building: The Failure of International Intervention, 153.

35 Harry Eckstein, Internal War: Problems and Approaches (Glencoe: Free Press, 1964), 28; Paris, "Peace Building and the Limits of Liberal Internationalism", 57; Anthony Cordesman, The War after the War: Strategic Lessons of Iraq and Afghanistan (Santa Monica: RAND Corporation, 2003), 48; Jenkins and Plowden, Governance and Nation-building: The Failure of International Intervention, 147-165; Somit and Peterson, The Failure of Democratic Nation Building, 46. Chesterman, You, The People; The United Nations, Transitional Administration and State-Building, 112.

36 Gary Dempsey, "Fool's Errands: America's Recent Encounters with Nation-building”, Mediterranean Quarterly, 12:1 (2000), 59. 
US forces, who become targets of local resentment and resistance, as they did in Afghanistan and Iraq. And yet over time they also may become a substitute for an indigenous security apparatus, leaving a security vacuum if and when they depart. In Kosovo and Bosnia, for example, the US accepted a premature power transition back to domestic forces, which was highly destabilizing. There were no substantial efforts to train a police force, army, or civil service, with negative repercussions that are still being felt in those countries. ${ }^{37}$

An element connected to security and governance is the rule of law. The new legal system must account for the unique social and cultural nuances of the target country. If this occurs, an effective judiciary and police force may enhance the credibility of the state and facilitate a peaceful transition to independence. Nation-builders must therefore facilitate legal reform and create institutions that can outlast the international presence. This can be achieved through legal planning, international mentoring, oversight to prevent bias and corruption, vetting and training judges and lawyers, building legal infrastructure and providing equipment and expertise. ${ }^{38}$ Without such mechanisms, individuals or groups may take matters into their own hands, which can result in torture and extrajudicial execution.

Finally, the success of nation-building can stand or fall on what is often described as 'development'. This incorporates economics, health, education, agriculture, electricity, transport and other infrastructure projects. Economic assistance, for example, seeks to expedite economic recovery to produce a selfsustaining economic system. The key issues in economic development are, in the first instance, currency stabilization, realigning revenue and expenditure, controlling inflation, capacity building and establishing accountability and combating corruption..$^{39}$ Education, meanwhile, provides a means to forge greater national unity and instil faith in the principles of law, governance and human rights. It also facilitates the production of skilled graduates, and can help ease ethnic and religious tensions. In respect of all development projects, Fukuyama argues that domestic actors must be empowered. 'We should be arriving with resources to motivate the natives $[\mathrm{sic}]$ to design their own factory and to help them figure out how to build and operate it themselves'. Thus development projects should utilize techniques that persuade the domestic populace to embrace the nation-building process. $^{40}$

Each aspect of nation-building is interconnected and interdependent. Economic and political growth is mutually reinforcing and a functioning government will

37 Chesterman, You, The People; The United Nations, Transitional Administration and State-Building, 113-143.

38 Dobbins et al., The Beginners Guide to Nation-building, 75-100.

39 Ottaway, "Rebuilding State Institutions in Collapsed States", pp. 1007 and Dobbins et al., The Beginners Guide to Nation-building 161-178.

40 Pulparampil, Models of Nation-building: A Critical Appraisal, 25; Francis Fukuyama, State Building, Governance and World Order in the Twenty-first Century (London: Profile Books, 2004). 
help to ensure the efficacy of development projects. Development projects, in turn, may promote a higher standard of living and create economic opportunities. Yet all of these efforts rely on a secure and stable environment. An ad hoc approach that neglects any of these dimensions encourages fragmentation, duplication and, ultimately, failure. Paris argues that the inability of would-be nation-builders to reach common objectives is a complex, multifarious problem. Different conceptions, goals and interests manifest within countries; between civilian and military factions; between governments and NGOs; and also within the UN system 'where bureaucratic rivalries and turf battles are legion' ${ }^{41}$ To more fully appreciate how such challenges were met or not met in Afghanistan after 2001, it is necessary to briefly outline something of the history of that war-torn country.

\section{A History of the Afghan State}

Afghanistan has frequently been described as a highway of conquest and the graveyard of empires. ${ }^{42}$ This fearful reputation is deserved, as the following overview attests.

Ahmand Shah, a Durrani chieftain, established the Afghan State in 1747. He instilled a semblance of order over a territory previously divided among autonomous provinces and regions. This was achieved by managing and manipulating a web of powerful tribal factions, through diplomacy, violence and distributing the spoils of war. Justice was dispensed through the pulwar; and Ahmand Shah's tribal army enforced the will of their chieftain. He was, in essence, a totalitarian ruler fashioned from the same mould as Genghis Khan and Ibn Saud. But the system of governance that he had created 'lacked the capacity to be institutionally self-generating and self-propelling', ${ }^{43}$

Following the death of Ahmand Shah and his son, Timur Shar, a period of turmoil ensued, in which competing tribal factions fought for power. Corruption and opportunism were the hallmarks of politics during this era of what Miller describes as an 'ever-shifting kaleidoscope of betrayal'. ${ }^{44}$ By 1826, Dost Mohammad Khan

41 Roland Paris, "Understanding the "Coordination Problem" in Postwar Statebuilding", in Roland Paris and Timothy Sisk, The Dilemmas of Statebuilding: Confronting the Contradictions of Postwar Peace Operations (New York: Routledge, 2009); Dennis Rondinelli, "Economic Growth and Development Policy in Afghanistan: Lessons from Experience in Developing Countries", in John Montgomery and Dennis Rondinelli (eds), Beyond Reconstruction in Afghanistan: Lessons from Development Experience (New York: Palgrave Macmillan, 2004), 115-130; Robert Muscate, "Lessons from Post-Conflict Aid Experience", in Montgomery and Rondinelli, Beyond Reconstruction in Afghanistan, 93-100; Paul Streeten, The Frontiers of Development Studies (New York: Palgrave Macmillan, 1980).

42 Seth Jones, In the Graveyard of Empires: America's War in Afghanistan (New York: W. Norton and Company, 2010).

43 Amin Saikal, Modern Afghanistan: A History of Struggle and Survival (London: I.B.Tauris, 2004), 23.

44 Kyber Miller, cited in Jeffery Roberts, The Origins of Conflict in Afghanistan (Connecticut: Westport, 2003), 11-12; Mountstuart Elphinstone, An Account of the Kingdom of Caubul, Vol II Karachi (Oxford: Oxford University Press, 1972), 249-263. 
had restored a semblance of order to the Afghan political landscape. Yet fluctuating tribal and ethnic divisions continued to dominate Afghan politics. The limited reforms he undertook were restricted to Kabul and its surrounding areas.

Intervention by Britain in 1839 resulted in the end of Dost Mohammad Khan's reign, and Britain's army easily overcame Afghan opposition. The British installed Shah Shuja as the new ruler of Afghanistan. But to most Afghans he was merely a puppet, 'propped up by British bayonets, supported by British gold, sustained by British and Indian blood'. ${ }^{45}$ The Mullahs, who were exempt from the governance system, portrayed the British as immoral infidels, and the tribal authorities were angered by the fact that colonial rule had disrupted the country's clan hierarchy.

The British were the first to experience the ferocious guerrilla tactics employed by Afghans in resistance to foreign occupation. After the slaughter of its soldiers, Britain retaliated with an 'Army of Retribution', which sacked Kabul in October 1842. It then abruptly departed to avoid being embroiled in a protracted conflict in a country that resented its imperialistic presence. Dupree summarized the frivolity of Britain's first occupation: 'after four years of disaster, both in honor, material and personnel, the British left Afghanistan as they found it, in tribal chaos and with Dost Mohammad Khan returned to the throne of Kabul' ${ }^{46}$

Dost Mohammad placed the reunification of Afghanistan as his top priority, focusing almost exclusively on cultivating his military power. His death in 1863 resulted in fratricidal conflict, which continued for six years. Sher Ali Khan emerged as ruler in January 1869. Like the Afghan leaders that had come before him, he prioritized the consolidation of an army to amplify his authority. But Sher Ali also improved Afghanistan's communications framework and initiated a number of infrastructure projects. He endeavoured to enforce national laws, and implement a taxation system. Yet the tribal and religious authorities rejected these efforts. Saikal asserts that 'despite his vision and craving for reforms, the Amir remained hostage to traditional forces present in the country'. ${ }^{47}$

Sher Ali Khan's period in office came to an abrupt end as a result of the second Anglo-Afghan war in 1879. Following the election of Benjamin Disraeli, Britain's pursuit of the 'Forward Defence Policy' triggered its second occupation of Afghanistan. Britain provided more robust financial and material aid to Afghanistan than it did during the 1840s, but its imperialistic attitude remained the same. Yaqub Khan, the new ruler, was once again perceived to be a British puppet by tribal and religious authorities. As tensions reached boiling point, the British envoy to Afghanistan was assassinated. A British Army again marched on Kabul, this time taking direct control of governance and employing martial law. The period was characterized by brutal punishments and arbitrary reprisals. While Britain had superior military experience, training, and equipment, however, it could not subdue the tenacious Afghan uprisings indefinitely. The British soon realized that they could not subject Afghanistan to a colonial model of

45 Louis Dupree, Afghanistan (Princeton: Princeton University, 1973), 369-378.

46 Dupree, Afghanistan, 399.

47 Saikal, Modern Afghanistan, 33. 
governance, and withdrew their forces in 1881. Gregorian writes that the wars 'unleashed a potent force in Afghan nationalism', which used Islam as 'a spiritual weapon'. ${ }^{48}$ It was a force with which future occupations would also struggle to contend.

Abdur Rahman Khan, 'The Iron Amir', filled the vacuum left by the departure of the British. His success was manufactured by intimidation and repression, secured through the use of an intricate spy network and an effective and dependable army. Rahman transformed the Afghan army from an amalgam of tribal militias into a permanent fighting force, embracing comprehensive reforms in weaponry, tactics and logistics. The army served primarily as a mechanism to enhance internal control, rather than as a shield against external threats. Abdur Rahman also established a basic communication network, civil service, police force, education system, rudimentary welfare services and a single currency.

The death of the Iron Amir generated yet another fratricidal conflict, from which Amanullah Khan emerged to rule Afghanistan in 1919. His ambition was to turn Afghanistan into a modern nation state, and he engaged in a series of major reforms that encompassed a wide range of issues. A network of roads was built along with communications infrastructure and a postal service. Amanullah placed education as a top priority. He hired French, Egyptians and Turkish teachers in an attempt to engender a European-style education. These programmes only resulted in the enrolment of 40,000 children in 1928, but this was still a step forward for Afghanistan's education system. Amanullah also engaged in fiscal and taxation reforms. Afghanistan adopted a new unit of currency and separated the public treasury from the private wealth of the Monarch, instigating the first national budget in 1922. Changes were applied to prevent corruption in the civil service, through training courses and programmes that were intended to facilitate a modern bureaucratic system. A formal judicial system was created, alongside a constitution, and Amanullah made a number of decrees in respect to women's rights, and the abolition of slavery and child labour. For the first time since the creation of the Afghan State, a ruler attempted to enact dynamic, revolutionary and far-reaching reforms, 'intended eventually to cut deep through the fabrics of Afghan micro societies and change their traditional values and practices' ${ }^{49}$

Many Afghans coveted the benefits and trappings a modern nation state could provide. It was in the interests of tribal and religious forces, however, to maintain the traditional status quo. Afghanistan's tribal and religious authorities still dominated the political landscape and they banded together to oppose Amanullah's reforms. On 14 January, 1929, faced with increasingly volatile opposition to his rule, Amanullah abdicated. Although the resistance of traditional forces was a principal reason for the failure of his reforms, there were other factors involved.

48 Vartan Gregorian, The Emergence of Modern Afghanistan: Politics of Reform and Modernization, 1880-1946 (Stanford: Stanford University Press, 1969), 6.

49 Saikal, Modern Afghanistan: A History of Struggle and Survival, 61-90; Gregorian, The Emergence of Modern Afghanistan, 242. 
Firstly, there was an absence of capital investment from outside sources, which meant that the finances available for the reforms were very limited. Secondly, Amanullah's government had neither the organizational skill nor the experience required to implement such dynamic changes. Thirdly, unlike previous Afghan rulers, he did not develop and consolidate the position of the army, which impacted upon his ability to ensure order and stability. ${ }^{50}$

The Tajik warlord, Bacha Saqqao, replaced Amanullah. His brutal and repressive rule lasted nine months, after which a Pushtun tribal force removed him. Nadir Shah obtained the throne, but he was left with no army, bureaucracy or treasury, all of which had disintegrated during Bacha Saqqao's brief reign. Nevertheless, Nadir Shah managed over time to build roads, a nation-wide police force and communications networks, while also instigating education and commercial reforms. But religious and tribal forces remained the 'foundations of power' ${ }^{51}$ A new constitution was crafted in 1931, through which authority was reinvested in the ulama. Additionally, the traditional social standing of women was imposed, and the teaching of western languages was banned.

Nadir Shah was assassinated on November 8, 1933, and Mohammad Zahir Shah replaced him as king. His position, however, was only ever ceremonial. Authority was vested in the office of Prime Minster, which was held consecutively by his uncles, each of whom balanced the need to appease tribal and religious authorities with cautious reforms. A national banking system was established and joint stock companies were created. There were also attempts to implement a national transport road network and enforce universal primary education. The second Prime Minister, Shah Mahmud, was influenced by a growing body of liberal-minded intellectuals and western-educated state officials. Popular elections in 1949 created a 'Liberal Parliament', which proposed a number of dynamic laws, the first of which was the establishment of a free press. But when the newly independent media stridently criticized the ruling clique, Shah Mahmud closed private newspapers and banned independent political organizations.

Mohammed Daoud supplanted Mahmud as ruler on 20 September, 1953. Daoud's goals were the consolidation of centralized authority, and he relied on the army to uphold the legitimacy of his regime. Yet he also attempted to modernize Afghanistan, and some historians have admired his reforms. ${ }^{52} \mathrm{He}$ implemented radical social and economic changes and successfully appealed for economic

50 Leon Poullada, Reform and Rebellion in Afghanistan, 1919-1929: King Amanullah's Failure to Modernize a Tribal Society (New York: Cornell University Press, 1973), 115-273; Gregorian, The Emergence of Modern Afghanistan, 252; Gilles Dorronsoro, Revolution Unending: Afghanistan 1979 to Present (New York: Colombia University Press, 2005), 62; Saikal, Modern Afghanistan: A History of Struggle and Survival, 73-79; Dupree, Afghanistan, 452; Saikal, Modern Afghanistan: A History of Struggle and Survival, 79.

51 Dupree, Afghanistan, 460.

52 Nancy Newell and Richard Newell, The Struggle for Afghanistan (New York: Cornell University Press, 1982), 52. 


\section{Background and Methodology}

support internationally. But his promotion of a nationalistic Pashtun creed provoked tensions with Pakistan, which resulted in his resignation.

With the removal of Daoud, King Nadir Shah was finally in control of the country. In the realm of education there was significant growth, with the number of primary school students doubling. Influenced by an emerging educated class, the king attempted to construct a constitutional monarchy. Unfortunately, this goal was nullified by the rural population's unpreparedness for civil rights and popular government. The 1964 constitution was plagued with 'critical deficiencies' and 'the executive and legislative branches remained at loggerheads'. ${ }^{53}$ Elections in 1965 and 1969 were superficial and political parties never became legalized. Anti-government protests and an outspoken press were quickly suppressed. Daoud returned to power through a coup in 1973. The alliance he forged with the People's Democratic Party of Afghanistan (PDPA) - Afghanistan's communist party - proved to be his downfall, as its leaders secured positions of power within the government and the army.

The Saur Revolution, instigated on 22 April, 1978, marked the beginning of PDPA rule in Afghanistan. This triggered a fountain of military and economic aid from the USSR. The PDPA was, in fact, completely dependent on the Soviets to maintain its rule. Although the party was tarnished by virulent internal turmoil, it nonetheless pursued ambitious reforms.

Spurred on by the Soviets, the PDPA applied drastic changes to marriage rights and agricultural practices, and outlined plans for a system of universal education. Each of these reforms exhibited the influence of Soviet-style Marxism. In essence, they represented an attempt to implement an ersatz communist blueprint 'a canned Soviet critique that could have been applied just as well (or ill) to any dozens of post-colonial countries' ${ }^{54}$ Such measures were at complete odds with many of Afghanistan's cultural traditions. The overhaul of rural property relations met especially strong resistance from tribes and villages, whose customary practices were uprooted. Meanwhile, changes in the role of women were perceived to be 'atheistic meddling in key Islamic rituals' ${ }^{55}$ Dupree asserts that 'it almost appears that they systematically planned to alienate every segment of the Afghan people'. Localized protests soon transformed into a national uprising; 'the rejection of the regime was universal', and 'one of the most truly popular revolts of the twentieth century'. ${ }^{56}$ While the army had been vital to the ascendance of the PDPA, its disintegration through mutiny, desertion and purges meant that it was unable to restore order.

53 Richard Newell, The Politics of Afghanistan (New York: Cornell University Press, 1972), 195.

54 Rubin, Secrets of State: The State Department and the Struggle over Foreign Policy, 85.

55 William Maley, The Afghanistan Wars (London: Palgrave MacMillan, 2009), 25.

56 Louis Dupree, cited in Thomas Hammond, Red Flag Over Afghanistan: The Communist Coup, the Soviet Invasion, and the Consequences (Boulder: Westview Press, 1984), 69; Dorronsoro, Revolution Unending: Afghanistan 1979 to Present, 97. Newell and Newell, The Struggle for Afghanistan, 84. 
With the collapse of the PDPA being imminent, the Soviet Union invaded Afghanistan in December 1979. In similar fashion to the British, they swiftly gained control of the major urban centres. The Soviets appointed a ruler, but again, in similar fashion to the British, the Afghan populace dismissed him as a puppet. As Newell and Newell suggest, 'Afghan officials became ornaments, handing the phone to their Soviet counterparts when matters of substance were to be discussed'. During the occupation, the Soviets engaged in infrastructure development and established an extensive bi-lateral trade network. But they ignored Afghanistan's complex political landscape and its cultural nuances. This was 'the height of futility' and caused a national uprising analogous to the one that had been faced by the British. Unified under the banner of Islam, and encouraged and supported by the US, the core of this resistance was known as the Mujahedeen. The contest against the Soviet military leviathan was asymmetrical, but the Mujahedeen successfully opposed the Soviets through a blend of guerrilla tactics and advanced, US-supplied weaponry. ${ }^{57}$

The Soviet prediction that its forces would remain in Afghanistan for six months proved to be erroneous. It soon became apparent that 100,000 soldiers were not near enough to hold territorial gains. Its attempts to reinvigorate the Afghan army were plagued by desertions, infighting and ethnic and tribal divisions, which determined that the loyalty of the army to the state was tenuous at best. By 1988, the Soviets had lost 50,000 men, caused 1.24 million Afghan deaths, and created five million refugees. Gorbachev saw the Soviet presence in Afghanistan as 'a bleeding wound', and removed its forces before the end of the year. This left 'Afghan society rent to pieces, the economy in tatters, a vast number of Afghans dead and the survivors profoundly traumatized'. ${ }^{58}$

Following the withdrawal of Soviet forces, conflict erupted and Afghanistan slipped into anarchy. As a state, Roy argues, it fundamentally ceased to exist. The 1992 Peshawar Accords nominally created an interim government to incorporate the diverse Mujahedeen factions. But in reality warlords carved out kingdoms of autonomous rule, with Islam being used as 'a lethal weapon'. ${ }^{59}$ In such an environment, the Taliban arose as a religious and social movement that promised to restore security and purge corruption.

They swept through the country like wildfire, with tribal authorities and warlords offering little opposition. By September 1995 the Taliban had occupied Kabul, and in 2001 they were in control of approximately 95 per cent of the country. The Taliban government capably imposed order through intimidation and corporal punishment, but its strict religious dogma was antithetical to reform and

57 Newell and Newell, The Struggle for Afghanistan, 120; Rubin, Secrets of State: The State Department and the Struggle over Foreign Policy, 85; Newell and Newell, The Struggle for Afghanistan, 78; Maley, The Afghanistan Wars, 66.

58 Dorronsoro, Revolution Unending: Afghanistan 1979 to Present, 192; Saikal, Modern Afghanistan: A History of Struggle and Survival; Maley, The Afghanistan Wars, 9 and 198.

59 Olivier Roy, Islam and Resistance in Afghanistan (New York: Cambridge University Press, 1990), 149. 


\section{Background and Methodology}

progress. In 1979, for example, Afghanistan had 220 working factories. By 1999 there were just six. ${ }^{60}$ The Taliban made no substantial attempts to rectify the damage sustained in the previous two decades of civil war. Instead, its leader, Mullah Omar, fostered an intimate relationship with Al Qaeda, one consequence of which was the US invasion of his country in October 2001.

\section{Conclusion}

As we have seen, then, war, religion, and tribal hierarchies made it difficult for Afghanistan to advance historically, with much progress being reversed each time a new conflict erupted. The experiences of both Britain and the Soviet Union should have served as warnings to the United States that a forceful military presence, coupled with an ambitious democratic programme, would face major hurdles. Bearing Afghanistan's past in mind, it is not surprising that the country was considered alien by one of the first western observers, Mountstuart Elphinstone, who said for outsiders it would be 'difficult to comprehend how a nation could subsist in such disorder' ${ }^{61}$ To combat that disorder, the United States would need a whole-of-government strategy, which combined the expertise and resources of its various agencies and individuals. But the problems illuminated by a review of Afghanistan's history congealed with the ambiguity and complexity of nationbuilding itself. Moreover, the shape and nature of the US bureaucracy, to which we now turn, created its own obstacles to realizing nation-building goals.

60 Ahmed Rashid, "The Taliban: Exporting Extremism", Foreign Affairs, November/December (1999), 25-35.

61 Elphinstone, An Account of the Kingdom of Caubul, 178. 


\section{Bureaucratic Politics and Nation-Building}

In the realm of domestic politics and administration, it is widely accepted that the United States is far from united. Socio-economic and cultural cleavages overlay a fractured political geography, with structural divisions being shaped by US history and federalism. These divisions are reflected in governance. Conflict within and between a myriad of state and federal government agencies has been extensively discussed in scholarship examining US democracy and bureaucracy. ${ }^{1}$ Yet when we shift from domestic to foreign policy the picture is somewhat different. Although most reputable scholars would accept that conflict does not 'stop at the water's edge', there is still, nonetheless, a tendency to speak of US interests, US strategy and US behaviour in overly unitary terms. Along with this is the distinct but related assumption that the United States functions as a rational actor. This framework for thinking about and analysing US foreign policy - hereafter referred to as the rational actor model (or RAM) - has been so dominant that 'we rarely remember we are reasoning by analogy'. ${ }^{2}$ From such a perspective, shared values, ideas and interests are the fulcrum around which US foreign policy turns.

The rational actor model has some limited usefulness in terms of identifying broad patterns and trends, but it is rather less insightful when it comes to describing and explaining the finer grained, contested aspects of US foreign policy making. In particular, it underestimates the impact of bureaucratic politics on the formulation, interpretation and implementation of specific policy decisions. This chapter offers an alternative framework for analysing US foreign policy in general and US nation-building in Afghanistan in particular. Bureaucratic politics is at the core of this framework. This focus on the foreign policy bureaucracy is not, of course, without precedent. During the 1970s, the Carnegie school revealed that beneath the monolithic US State, there are 'various gears and levers in a highly

1 Thomas Hammond and Jack Knott, "Who Controls the Bureaucracy?: Presidential Power, Congressional Dominance, Legal Constraints, and Bureaucratic Autonomy in a Model of Multi-Institutional Policy-Making”, The Journal of Law, Economics and Organization, 12: 1 (1996), 120. William Gormley, Bureaucracy and Democracy: Accountability and Performance (Washington DC: CQ Press College, 2013).

2 Allison, Essence of Decision, 252. 
differentiated decision-making structure'. ${ }^{3}$ To understand foreign policy decisionmaking, one has to understand the 'various gears and levers' and the tensions between them. These gears and levers include, but are not limited to, the President, Congress, the US military and the various bureaucratic agencies of executive government, all staffed by professional officials with differing interests and differing images of the world. In an updated version of an earlier work, Halperin et al. note that the participants in the foreign policy bureaucracy,

... while sharing some images of the international scene, see the world in very different ways. Each wants the government to do different things, and each struggles to secure the decisions and actions that he or she thinks best. ${ }^{4}$

Despite continued attention in works such as that of Halperin et al., it would be fair to say that scholarship on bureaucratic politics is something of a poor cousin in the International Relations literature. Focused empirical studies on struggles within and between the agencies of the US foreign policy bureaucracy are relatively few. This chapter develops a new bureaucratic politics model that builds upon the strengths of the current literature, while recognizing and transcending its weaknesses.

The chapter begins by first outlining the key assumptions of the rational actor model. It continues with a critique of the RAM and a discussion of the ways in which bureaucratic politics confound and obstruct decisions taken by rational actors, including the President. Finally, an alternative model of bureaucratic politics is elaborated, centred on four interrelated, but distinct variables: bureaucratic interests, perceptions, culture and power.

\section{The Rational Actor Model}

Students of international relations often assume that the state is a unitary actor. From this perspective, one typically associated with realism, the foreign policy bureaucracy is a rational and relatively unified entity. ${ }^{5}$ The rational actor model argues that although there may be debate and discord within government circles, shared interests, goals and values ultimately shape a national state's foreign policy. Consequently, explaining foreign policy revolves around identifying the interests of the state, which are embodied in its leaders, who are able to determine the decisions and actions of the state in an international context. ${ }^{6}$ Options for

3 Ibid., 6.

4 Morton Halperin and Priscilla Clapp, with Arnold Kanter, Bureaucratic Politics and Foreign Policy (Washington DC: Brookings Institute, 2006).

5 Stephanie Lawson, International Relations (Cambridge: Polity, 2003).

6 Morton Halperin, Bureaucratic Politics and Foreign Policy (1974), and Graham Allison and Morton Halperin, "Bureaucratic Politics: A Paradigm and Some Policy Implications", in Raymond Tanter and Richard H. Ullmann, Theory and Policy in International Relations (Princeton: Princeton University Press, 1972). 
a given foreign policy direction are considered, and then a path is chosen that reflects the combined values of the decision-makers. This includes assessing the various courses of action available and the costs/benefits of each alternative. As Welch notes, the RAM, 'conceives of states as unitary and purposive, making consistent, value-maximizing choices'?

The rational actor model certainly has its advantages. First, it is a clear and coherent method that is easy to apply to most foreign policy issues. Second, it is well developed and can offer objective and neutral standards of evaluation. Third, it promotes varied and imaginative analysis to generate diverse hypotheses centred on government choice and reasoning. Finally, it allows 'an armchair strategist' to produce accounts of a given foreign policy incident without the need to draw on a mass of empirical evidence. ${ }^{8}$

The rational actor model provides an overarching template that can fuse competing international relations theories, thus providing 'basic tools for explaining general theoretical statements'. ${ }^{9}$ It can lead to the construction of a flexible model, which may be as complex as necessary, but at the same time straightforward and coherent. Some scholars consider the RAM to be a simplified model that still retains significant analytical power. ${ }^{10}$ By focusing on macrocosmic trends and themes, the rational actor model bridges the gap between individual behaviour and collective action. Its focus on unity also gives license to logically interpret a correlation or a set of events 'through plausible and compelling story' that uncovers universal principles and causal mechanisms. ${ }^{11}$ Consequently RAM theories characterize a States as having a certain set of norms and beliefs, which opens the possibility of explaining foreign policy over a long period of time. ${ }^{12}$ The RAM approach has been applied to a diverse range of problems, such as electoral choice, revolutionary movements, institutional formation and state-building.

Rationalist theorists criticize the bureaucratic politics approach, which Krasner has derided as 'misleading and dangerous' because it obscures the power of the US President and undercuts the expectations of democratic politics by discharging

7 David Welch, "The Organizational Process and Bureaucratic Politics Paradigms: Retrospect and Prospect”, International Security, 17:2 (1992), 114.

8 Deborah Stone, Policy Paradox: The Art of Political Decision Making (New York: Norton and Company, 2012), 14. Allison, Essence of Decision: Explaining the Cuban Missile Crisis, 246 and 251 .

9 James Morrow, "A Rational Choice Approach to International Conflict", in Nehemia Geva and Alex Mintz (eds), Decision-Making on War and Peace: The Cognitive-Rational Debate (Boulder: Lynne Rienner: 1997), 12-18.

10 Siegwart Lindenberg, "The Method of Decreasing Abstraction", in James Coleman and Thomas Fararo (eds) Rational Choice Theory: Advocacy and Critique (London: Sage, 1992), 18; Paul J.H. Schoemaker, "Strategic Decisions in Organizations: Rational and Behavioral Views", Journal of Management Studies, 30: 1 (1993), 107-129.

11 Margaret Levi, "A Model, a Method, and a Map: Rational Choice in Comparative and Historical Analysis", in Mark Irving Lichbach and Alan Zuckerman, Comparative Politics: Rationality, Culture and Structure (New York: Cambridge University Press, 1997), 19-42.

12 Morrow, “A Rational Choice Approach to International Conflict”, 12-18. 
high officials of responsibility for their actions. Government failures, Krasner argues, are 'not so much the inertia of a large bureaucratic machine as a confusion over values which afflicts the society in general and its leaders in particular'. A bureaucratic politics approach, from this perspective, also ignores the fact that objectives and values of foreign policy are 'perfectly coincident with the ethical assumptions of democratic politics'. Especially when it comes to the formation of policy, moreover, RAM provides explanations, whereas the bureaucratic politics approach, which focuses on disorder and obfuscation, does not. Nor does the bureaucratic politics approach offer much in the way of solutions beyond 'improving managerial techniques' with limited capacity to change the overall direction of foreign policy. Finally, evoking bureaucratic politics as a reason for foreign policy problems has been used as an excuse for leaders to blame their deficiencies on the bureaucratic structure of the US State. ${ }^{13}$

Given these strengths, it is perhaps unsurprising that the RAM has produced a large and important body of scholarship on the foreign policy of the United States. Above all, the RAM has been the theoretical lens through which issues of national security have been viewed. The reason for this is clear: during moments of national security threat the US government and its officials are more likely to speak with one voice than at other times. Should the President place a foreign policy issue within the frame of national security, it will usually generate public support, bi-partisan resolve and bureaucratic unity of purpose. Huntington argues that after the bombing of Pearl Harbor, for example, 'a remarkable harmony prevailed in the high councils of the American government'. Military personnel, politicians, bureaucrats and the US populace were united in their shock and outrage. ${ }^{14}$

More recently, much the same has been said of reactions in the US government immediately after the 9/11 attacks. Irrespective of one's assessment of the Bush regime's response, and regardless of whether or not the impetus for it sprung from Bush, his top foreign policy advisors or a cabal of neo-conservatives, it is generally accepted that there was relative unity, at least initially, in responding with decisive military force. James Mann notes that there was clarity of purpose within the Bush Administration, where 'the interconnecting relationships and the overhang of the past extended down through the ranks of the faithful' ${ }^{15}$ Andrew Bacevich, speaking from a very different theoretical and political position, places the response within a broader historical context where national security has created a 'Washington Consensus'. Although he notes that officials often pursue 'the favored agendas of their own agencies', he argues that 'an emphasis on coercive

13 Stephen Krasner, “Are Bureaucracies Important? (Or Allison Wonderland)", Foreign Affairs, 7 (1972), 159-179.

14 Samuel Huntington, The Soldier and the State: The Theory and Politics of Civil-Military Relations (Harvard University Press, 1957), 326.

15 James Mann, Rise of the Vulcans: The History of Bush's War Cabinet (New York: Viking, 2004), xi. 
power held at the ready; and a penchant for global interventionism, both overt and covert', is what characterizes the US foreign policy system as a whole. ${ }^{16}$

The rational actor model has not been restricted to the issue of national security. In a detailed study of US Anti-Expropriation policy, Lipson claims that although the White House, Congress and various agencies have independent interests, they are united by 'common ideology, common symbolic referents and a shared understanding of certain state function'. He suggests that this produces broad areas of agreement, which is more important than the divergent opinions of various factions within the foreign policy bureaucracy. ${ }^{17}$ Expressed differently, the imperatives of bureaucratic interest are trumped by national interest and the shared ideology on which it rests, which in turn allows us to think of the US as being a relatively unified, rational actor. While such an approach may help to identify broad patterns of state behaviour, ultimately it is based on questionable assumptions that underestimate the complexity of US foreign policy making. However, in spite of Krasner's dismissal of the bureaucratic politics approach, the rational actor model is a paradigm that neglects the 'bureaucratic jungle' that encroaches on the shores of US foreign policy. ${ }^{18}$

In the 1970s, a body of scholarship began to emerge that questioned the key assumptions of the RAM, while elaborating an alternative approach that focused on the differentiated role of the US foreign policy bureaucracy. Published more than four decades ago, Graham Allison's Essence of Decision remains a key early text in this tradition, and still has lessons for scholars today. Although he focuses on a particular foreign policy event - the Cuban Missile Crisis - his analysis has a broader relevance for understanding US foreign policy.

In discussing the crisis that unfolded in October 1962, after the US learned that the Soviets had positioned ballistic missiles in Cuba, Allison proposes and analyses three possible models that could be deployed to explain US policy. Model I is equivalent to the RAM. To explain the US response, particularly the US naval blockade of Cuba, this model focuses on strategic calculus, US capabilities, and relevant US values and interests. Using this backdrop, Model I considers US actions to represent a 'purposive response to the strategic problem'. The blockade 'is an aggregate act' and 'the perceived context, formal decision, and implementation are all aspects of one coordinated, rational choice'. In his discussion, Allison concludes that the assumptions and predictions of Model I are 'crudely reductionist', as they ignore agency interests and other bureaucratic considerations. ${ }^{19}$ Many other scholars display similar reservations and argue that it is presumptuous

16 Andrew Bacevich, Washington Rules, 247; Andrew Bacevich, The Limits of Power: The End of American Exceptionalism (New York: Metropolitan Books, 2008), 95.

17 Charles Lipson, Standing Guard: Protecting Foreign Capital in the Nineteenth and Twentieth Centuries (Berkeley: University of California Press, 1985).

18 Daniel Drezner, "Ideas, Bureaucratic Politics, and the Crafting of Foreign Policy", American Journal of Political Science, 44: 4 (2000), 734.

19 Allison, Essence of Decision, 250 and 254. 
to 'assume the existence of a central intelligence and guiding force' ${ }^{20}$ Whether explaining the past or the future, the weakness of the rational actor model is that it assumes that the United States chooses a course of action in order to realize its foreign policy goals 'most efficiently and economically'. ${ }^{21}$ Such an approach, Halperin observes, relies on a 'dignified, even majestic progression, with each of the participants having well-defined roles and powers' ${ }^{22}$ Most of the bureaucratic politics literature agrees that there is no strict order or rules to foreign policymaking; rather it comes as a result of bargaining and negotiation between the relevant parties. ${ }^{23}$

Allison's Model II and Model III abandon the presumption that the United States functions as a unitary and purposive subject. Model II proposes that US foreign policy is not produced by a single calculating decision-maker, but instead by a number of agencies within government: "The actor is not a monolithic "nation" or "government", but rather a constellation of loosely allied organizations on top of which government leaders sit'. On the basis of this model, Allison suggests that foreign policy is less a reflection of deliberate choices than a compromise between large agencies with diverse interests, which operate in accordance with deeply entrenched patterns of behaviour. ${ }^{24}$ Welch, who reviewed Allison's models 20 years later, agrees. He claims that the usefulness of the Rational Actor Model 'should not be permitted to obscure the fact that rationality is constrained in various important ways by factors that are either determined or strongly influenced by organizational or bureaucratic considerations, ${ }^{25}$

Allison's Model III, meanwhile, contends that individuals who sit at the forefront of foreign policy are neither a monolithic group, nor merely an emblem of the agencies that they represent. Instead, each actor is engaged in a complex political game where decisions are made 'not by a single, rational choice but by the pulling and hauling that is politics'. ${ }^{26}$ With this in mind, Model III posits that decisions are a consequence of 'intelligent interest-based action by rational

20 Destler, Presidents, Bureaucrats and Foreign Policy: The Politics of Organizational Reform, 5.

21 Roger Hilsman, The Politics of Policy Making in Defence and Foreign Affairs (New Jersey: Prentice Hall, 1990), xi.

22 Roger Hilsman, "The Foreign-Policy Consensus: An Interim Research Report”, Journal of Conflict Resolution, 3:4 (1959), 362.

23 Huntington, The Soldier and the State; Allison, Essence of Decision; Hilsman, The Politics of Policy Making; Walter Schilling, "The Politics of National Defence", in Thomas Hammond, Walter Schilling and Paul Snyder (eds), Strategy, Politics and Defence Budgets (New York: Columbia, 19620, 21-26; David Kozak, "The Bureaucratic Politics Approach: The Evolution of the Paradigm", in David Kozak and James Keagle (eds), Bureaucratic Politics and National Security: Theory and Practice (Boulder: Lynne Rienner, 1988), 13.

24 Allison, Essence of Decision, 3, 80 and 67.

25 Welch, "The Organizational Process and Bureaucratic Politics Paradigms: Retrospect and Prospect", 138.

26 Allison, Essence of Decision, 144 and 146; Robert Jervis, "Why Intelligence and Policy-makers Clash", in James McCormack (ed.), The Domestic Sources of American Foreign Policy: Insights and Evidence (Maryland: Rowman \& Littlefield, 2012), 267-285. 
players in a complex, partially hidden intergovernmental game'. ${ }^{27}$ In another study, Allison and Halperin refined and expanded Model III, in order to produce a broader theoretical approach. But the core of their approach remains that, 'the individuals within a government, and the interaction among them, [are] determinants of the actions of a government' ${ }^{28}$ More recent academic criticism of the rational actor model makes the argument that it fails to account for the way in which ideas impact on the behaviour of individuals. Drezner, for example, claims that the rational actor model relies on dominant ideas, but fails to account for what happens when competing ideas assert themselves. ${ }^{29}$ Often competing ideas are abstracted from the institutional bases from which they arise, and treated as if they have material consequences that can be understood in isolation from the actors and institutions that promote them. ${ }^{30}$

What Allison and other scholars have demonstrated is that competing conceptions and interpretations impact upon each foreign policy issue. This is because the bureaucracy consists of parochial agencies, factions and individuals. The ability of the US foreign policy establishment to act as a single, rational and thus purposeful unit is constrained by the behavioural nuances of its various parts. ${ }^{31}$

\section{The President and the Bureaucracy}

Sceptics of this view might immediately ask: but what of the President? Does he not transcend the machinations of the foreign policy bureaucracy and have the power to ultimately determine foreign policy? Many have thought so. Arthur Schlesinger characterizes the US President as an imperial dictator of foreign policy, 'on the issues of war and peace the most absolute monarch among the great powers of the world'. ${ }^{32} \mathrm{He}$ is 'the President Emperor', Bacevich writes, who 'functions as the ultimate decider' in foreign affairs. ${ }^{33}$ While these descriptions are an exaggeration, the President and his advisers do have the capacity to dominate a foreign policy issue.

Prima facie, there might appear good reasons for accepting this view of Presidential powers and their critical role in determining the particular 'rationality' of US foreign policy. The President can set the rules of engagement, appoint key

27 Edward Rhodes, "Do Bureaucratic Politics Matter? Some Discomfiting Findings from the Case of the US Navy", World Politics, $47: 1$ (1994), 2.

28 Allison, Essence of Decision; Allison and Halperin, "Bureaucratic Politics: A Paradigm and Some Policy Implications", 43.

29 Drezner, "Ideas, Bureaucratic Politics, and the Crafting of Foreign Policy".

30 Paul Rohrlich, "Economic Culture and Foreign Policy: The Cognitive Analysis of Economic Policy-Making”, International Organization, 41: 61, 92.

31 Stone, Policy Paradox, 10-14; Welch, "The Organizational Process and Bureaucratic Politics Paradigms: Retrospect and Prospect", 116-117.

32 Arthur Schlesinger, The Imperial Presidency (New York: Popular Library, 1973), 11.

33 Bacevich, The Limits of Power, 84. 
figures and establish channels of communication. ${ }^{34}$ Informally, his prestige and reputation constitute 'a useful antidote to bureaucratic immobilization'. ${ }^{35}$ When it comes to matters of warfare and national security the US Commander-in-Chief is especially well equipped to shape policy, leading General Douglas MacArthur to quip that the US military is 'merely the agent of the President'. ${ }^{36}$ Despite Congress having the Constitutional authority to declare war, it has in fact been the President who has led the US into every major war since Korea in 1950, albeit while sometimes relying on enabling resolutions from Congress, as was the case with Vietnam in 1964 and Iraq in 2002. More recently, the form and substance of the War on Terror was fashioned by President George W. Bush and his senior staff. All of this suggests that leadership from the White House fuses the US into a united, rational actor.

While the Presidential powers sketched above do lend some weight to the idea that the US can act with unity of purpose, it neglects the ways in which even Presidents are constrained. Neustadt argues, for example, that the President is circumscribed by bureaucratic forces and must still make use of his power to persuade and bargain if he wishes to accomplish his goals. ${ }^{37}$ Persuasion and bargaining entails compromise, but also unintended consequences of the deals struck. This implies that rather than directing agencies and officials to form rational, coherent policy, the White House fights a constant battle against a variety of agencies and individuals. The will of the President does not necessarily translate into substantial policy action. ${ }^{38}$

Many scholars also highlight the capacity of the President to breach bureaucratic barriers at the policy formulation stage, while being much more constrained at the implementation stage. ${ }^{39}$ Destler, for example, observes that we "tend to forget the often substantial gap between what our Presidents seek and what the bureaucrats officially working for them actually do ${ }^{40}$ Holbrooke draws a similar conclusion: due to its size and make up, 'the foreign affairs community cannot be pulled together under any central agency - not even the White House' ${ }^{41}$ The President can make decisions and guide the behaviour of a handful of senior officials, but he finds it more challenging to oversee implementation and the daily actions of an army of bureaucrats. ${ }^{42}$

34 David Lewis, The Politics of Presidential Appointments: Political Control and Bureaucratic Performance (Princeton: Princeton University Press, 2008), 51-81.

35 Morton Halperin and Arnold Kanter, "The Bureaucratic Perspective: A Preliminary Perspective", in Halperin and Kanter (eds.) Readings in American Foreign Policy: A Bureaucratic Perspective (Boston: Little, Brown, 1973), 6-7; Allison, Essence of Decision, 148; Destler, Presidents, Bureaucrats and Foreign Policy, 88.

36 Huntington, The Soldier and the State, 414.

37 Richard Neustadt, Presidential Power (New York: Free Press, 1991), 11.

38 Garry Clifford, "Bureaucratic Politics", 93-94.

39 Krasner, “Are Bureaucracies Important? (Or Allison Wonderland)", 169.

40 Destler, Presidents, Bureaucrats and Foreign Policy, 20.

41 Richard Holbrooke, “The Machine that Fails", Foreign Policy, January 1, 1971, 4, http://www. foreignpolicy.com/articles/the_machine_that_fails.

42 Halperin, Bureaucratic Politics and Foreign Policy (1974), 236. 
Aggravated by this realization, many US Presidents have perceived the bureaucracy to be their natural enemy. ${ }^{43}$ When Franklin D. Roosevelt vetoed the 'Pacific First' strategy, for example, the military establishment acquiesced but then undermined his authority by pursuing an alternative strategy for the remainder of WWII. ${ }^{44}$ Elements of the bureaucracy also frustrated John F. Kennedy by failing to extract Jupiter missiles from Turkey, despite an initial agreement with the President that the missiles were obsolete and the assurance that they would be removed. Ted Sorensen, the Special Counsel and Advisor to Kennedy, remarks that it was never certain 'who was in charge, who was clearly delegated to do what and why his policy line seemed consistently to be altered or delayed' ${ }^{45}$

Evidently, there is a significant gap between a policy direction that is chosen by the President and the way in which his orders are carried out. This highlights a broader problem; that it is impossible to closely monitor and control all of the agencies and individuals that make up the US foreign policy establishment. Even where officials close to the President conscientiously try to implement his decisions, those more distant may, for personal or bureaucratic reasons, frustrate the effective execution of decisions taken at the top. In other words, decisions already taken continue to be debated at various points in the bureaucracy, and can effectively be ignored or reversed. ${ }^{46}$ Even the most diligent senior US official would find it impossible to observe and monitor all the activities of his or her subordinates. ${ }^{47}$ The structure of each agency and the US foreign policy system more generally, means that 'decisions are rarely tailored to facilitate monitoring'. As a consequence, 'senior players have great difficulty checking on the faithful implementation of a decision'. ${ }^{48}$ Destler has characterized this separation as one between policy and operations. The former is seldom able to adequately guide the latter, which results in conflicting interpretations between and within US agencies. ${ }^{49}$ Richard Holbrooke crystallizes the problem succinctly: 'Between the generalities of a vague policy document and its implementation . . . lies many places for miscalculation or derailment' ${ }^{50}$

The interpretation and implementation of policy reinforces agency norms and permits factional cleavages. Agency routine will often obfuscate or supersede any central rational choice made by senior officials or the President. At the implementation stage, the number of agencies and factions that become involved greatly expands, expanding the possibility for inter-agency competition and conflict.

43 M.S. Eccles, Beckoning Frontiers (New York: Knopf, 1951), 336.

44 Clifford, "Bureaucratic Politics", 93.

45 Ted Sorensen, Kennedy (New York: Harper \& Row, 1965), 287.

46 Allison, Essence of Decision, 172.

47 Welch, 'The Organizational Process and Bureaucratic Politics Paradigms: Retrospect and Prospect', p. 133.

48 Allison, Essence of Decision; Allison and Halperin, 'Bureaucratic Politics: A Paradigm and Some Policy Implications", 53.

49 Destler, Presidents, Bureaucrats and Foreign Policy.

50 Holbrooke, "The Machine that Fails", 4. 
Divisions also appear between the upper and mid/low level of the bureaucracy. Halperin draws a distinction between two types of bureaucrats: senior participants and junior participants. Allison more colourfully described these two categories as Chiefs and Indians. In their subsequent collaborative study, the two combined these monikers to argue that there is a dichotomy between what they call decision games and action games. While senior officials dominate decision games, action games give mid- and low-level officials the ability to play a more significant role. When all of these factors are considered, it is little wonder that Henry Kissinger could claim that, 'making foreign policy is easy, what's difficult is its coordination and implementation'. ${ }^{51}$

\section{A New Bureaucratic Politics Model}

The foregoing discussion suggests that US foreign policy making is a more complex phenomenon than the rational actor model suggests. Yet Allison's alternative embryonic models, and the others that have followed, have also been subject to criticism. These criticisms typically turn around two alleged weaknesses. On the one hand, it is said that they over-emphasize the volitions of individuals and do not pay sufficient attention to the bureaucratic agencies themselves - their form, function and broader institutional context. On the other hand, the models are said to be rigid and untested, and unable to provide a complete picture of 'how the bureaucracy is controlled and who controls it'. ${ }^{52}$ In other words, they provide an incomplete picture of how the foreign policy bureaucracy actually works, and what are the mechanisms that link it with foreign policy outcomes.

The purpose of this chapter is not to interrogate these criticisms at length, but they do illuminate some of the shortcomings in existing approaches to bureaucratic politics. To overcome these deficiencies, a new bureaucratic politics model will be introduced, one centred on bureaucratic interests, perceptions, culture and power. For the purpose of presentation each of these will be discussed as if they constitute a distinct phenomenon. In reality they are overlapping and mutually constitutive. The four variables are adaptable enough to explain how agencies function as a single purposeful unit, but also how they interact with other agencies, and how factions and officials within agencies behave. Importantly, the model that is outlined below does not constitute some universal theory that claims to explain all US foreign policy, but rather a framework for thinking through the failings of nation-building in Afghanistan, which may be applicable to similar cases.

51 Allison, Essence of Decision, 477; Allison and Halperin, "Bureaucratic Politics: A Paradigm and Some Policy Implications", 47.

52 Hammond and Knott, "Who Controls the Bureaucracy?: Presidential Power, Congressional Dominance, Legal Constraints, and Bureaucratic Autonomy in a Model of Multi-Institutional Policy-Making", 119; Welch, "The Organizational Process and Bureaucratic Politics Paradigms: Retrospect and Prospect", 120 and 138; Jonathan Bendor and Thomas Hammond, "Rethinking Allison's Model”, American Political Science Review, 86:2 (1992), 317. 
The first consideration in this new model is bureaucratic interests. Interest refers to that which is beneficial to an agency. Interests can be both tangible and intangible. Examples of tangible interests include the ongoing survival of an agency, but also its access to resources that can bolster its capacities. An example of an intangible interest is the prestige and status of an agency vis-à-vis other agencies in the foreign policy bureaucracy. Interests are important because they influence the goals and priorities of an organization, shape the behaviour of its personnel, and help determine how it interacts with other agencies and arms of government. Such interests often conflict with other agencies, not to mention with White House agendas and priorities. Rather than engaging in an ordered pursuit of common goals, each agency strategizes 'to survive and thrive in a world of competing ideas and institutions'. ${ }^{53}$ Agencies place survival above all else and will stifle any perceived threat to it. ${ }^{54}$

Instead of being strictly 'national', bureaucratic interests are by definition partial, interpreted to suit specific purposes such as increasing a budget, procuring resources or limiting costs. Indeed, agency interests are often far more concrete than the generalized national interest of the government. ${ }^{55}$ As a result, agencies will often attempt to undermine or overrule certain foreign policy initiatives. During the invasion of Grenada, for example, the military establishment deployed a battalion of Rangers for bureaucratic rather than tactical reasons in order to buttress congressional support for another Ranger battalion. ${ }^{56}$ When faced with human rights reforms throughout the Presidency of both Carter and Reagan, the Treasury Department fought against the linkage of economic assistance to a country's human rights record, and did everything in its power to avoid the application of trade restrictions that were justified by human rights considerations. ${ }^{57}$

It is no wonder, then, that conflict often erupts when a foreign policy issue involves multiple agencies with divergent interests. But this can also motivate compromise between agencies, which undermine the policy intent of decisionmakers in the White House. Holbrooke explains that agency programmes,

... are often carried out by one agency despite concern and even mid-level opposition from others, as part of a tacit trade-off: 'We'll let you do your thing, and you let us do ours'. Such deals or 'non-aggression treaties', are almost never explicit, but are nonetheless well understood by the participants.

53 Drezner, "Ideas, Bureaucratic Politics, and the Crafting of Foreign Policy", 733.

54 Valerie Hudson, "Foreign Policy Analysis: Actor-Specific Theory and the Ground of International Relations", Foreign Policy Analysis, 1:1 (2005), 8.

55 Chester Barnard, The Functions of the Executive: 30th Anniversary Edition (Cambridge: Harvard University Press, 1971); Herbert Simon, Administrative Behavior: A Study of Decision Making Processes in Administrative Organization (New York: Free Press, 1997).

56 Welch, "The Organizational Process and Bureaucratic Politics Paradigms: Retrospect and Prospect", 133.

57 Edwin Maynard, "The Bureaucracy and Implementation of US Human Rights Policy", Human Rights Quarterly, 11:2 (1989), 242. 
The results from such arrangements obviously vary. Sometimes programs are in direct conflict. ${ }^{58}$

During the Salt I negotiations, for example, the State Department and the Arms Control and Disarmament Agency were concerned with arms limitations, while the military was hostile to any move to reduce US firepower. Similar currents of discord were manifested in respect to Foreign Aid Sanction and Investment Protection, when different interests provoked a heated dispute between State and Treasury. In the early 1990s, meanwhile, a multitude of agencies clashed over US pre-war technology sales to Saddam Hussein's Iraq. ${ }^{59}$ To sum up, different sets of interests within agencies shape relations between them and often provoke conflict.

Bureaucratic interests are intimately bound up with and help mould bureaucratic perceptions. Perception refers to the ways that agency personnel tend to view the world, their place in it, and the problems that they confront. Perception is often encapsulated in the observation that "where you stand depends on where you sit'. Neustadt placed this adage at the centre of his study Presidential Power, arguing that the US government is characterized by a convoluted power sharing arrangement between and within separate agencies, who all view the world in very different ways. ${ }^{60}$ Allison and Halperin extended the aphorism to contend that, "where you sit influences what you see as well as well as where you stand (on any issue)', ${ }^{61}$

On any given issue an agency or government department will view the world through different lenses, which reflect their own partial interests and preoccupations. The US Treasury and Department of Commerce, for example, might view relations with China principally through an economic lens focused on trade, markets and potential revenue. The Pentagon, meanwhile, is more inclined to view China through a military lens that sees in that country a strategic competitor. Similarly, the proposal to withdraw American troops from Europe was considered by the State Department to be a development that would damage US relations with NATO; by the military to be a threat to its budget; and by the Treasury Department to be a way to save money. In the 1950s, the Anti-Ballistic Missile Program was viewed by the military as an initiative that would increase its budget and prestige. In contrast, the State Department worried that such an aggressive programme would negatively affect relations with US allies and provoke its adversaries. ${ }^{62}$ What these examples illustrate is that an agency's collective perceptions are very much shaped by its interests.

58 Holbrooke, "The Machine That Fails".

59 Jerel Rosati, "Developing a Systematic Decision-Making Framework: Bureaucratic Politics in Perspective", World Politics, 33:2 (1981), 239; Lipson, Standing Guard, 217; Juliet Kaarbo, "Power Politics in Foreign Policy: The Influence of Bureaucratic Minorities", European Journal of International Relations, 4:1 (1998), 68.

60 Neustadt, Presidential Power.

61 Allison and Halperin, "Bureaucratic Politics: A Paradigm and Some Policy Implications", 44.

62 Ibid., 48; Halperin, Bureaucratic Politics and Foreign Policy (1974), 27, 16. 
But perceptions do not only differ between agencies; they can also differ within an agency. Even officials within the same department can have differing perceptions regarding an issue, and have differences over what is considered to be the correct response to that issue. A foreign policy issue may be of significance to one person, yet trivial to another. Alternatively, each of them may consider the issue to be of importance, but for different reasons. The perceptions of military officials operating within a war-zone, for example, are distinct from those who are ensconced within the Pentagon in Washington.

Perception is also shaped by what Allison has termed 'peculiar preferences'. This refers to the personal likes or dislikes of US foreign policy officials. 'Personal baggage' may influence a US official's commitment to a certain issue, his stand in respect to another agency or his attitude toward the implementation of a particular project. ${ }^{63}$ Bloomfield highlights the capacity of 'fallible (or obstreperous) human beings to implement (or thwart) . . . foreign policy programs' ${ }^{64}$ During World War II, for example, personal animosity between Secretary of State Hull and Under-Secretary Wells, driven by very different perceptions of the international context and its problems, led each to undermine the other's authority, crippling the State Department's ability to function effectively.

Nonetheless, perception generally correlates with the position an individual holds within the foreign policy bureaucracy. Based on their proximate position, US officials have certain loyalties, receive certain information and are exposed to particular views and interpretations of how their agency's interests are best served. Despite the fact that the individual character traits of a US official can play a part, therefore, his behaviour is still inextricably linked to and constrained by the position she or he holds within the bureaucracy.

The way of perceiving the world and concrete foreign policy issues is not only shaped by agency interests. Perception is also influenced by and is a part of an agency's culture. Culture is here understood as the patterned beliefs, values and symbolic representations shared within a given group, which constrain thinking and instil behavioural norms. Each agency has a relatively distinct culture based on past experiences, repertoires and formal and informal procedures, which combine to create its own unique character. ${ }^{65}$ In Bureaucracy, Wilson emphasizes the role that culture plays: 'Every organization has a culture' he writes, 'a persistent, patterned way of thinking', which passes from one generation to the next'. An agency's culture embeds dominant images and ingrains certain expectations through doctrine and teaching, in order to influence the behaviour of its officials whether they are aware of it or not. ${ }^{66}$

63 Allison, Essence of Decision, 166-174.

64 Lincoln Bloomfield, "From Ideology to Program to Policy: Tracking the Carter Human Rights Policy”, Journal of Political Analysis and Management, 2:1 (1982), 12.

65 Jessica Einhorn, Expropriation Politics (Lanham: Lexington Books, 1974). H. Seidman, Politics, Position and Power: The Dynamics of Federal Organization (New York: Oxford University Press, 1970), 109.

66 Wilson, Bureaucracy, What Government Agencies Do and Why They Do It, 91-110. 
An agency's culture helps shape perceptions and interpret agency interests. It is, therefore, dangerously complacent to dismiss cultural nuances as a collection of 'idiosyncrasies' that can be easily overcome. ${ }^{67}$ It can inculcate a strong resistance to change, limit the exchange of ideas and provoke irrational reactions to a foreign policy directive, and reduce the available options for a policy's implementation. As a former Washington insider remarks of the inertia of agency culture, 'for every argument inside government that some jerry-built bureaucratic arrangement should be changed, there are usually twenty arguments to show that it rests on God's own logic'. ${ }^{68}$

'Standard operating procedures' embodied in and perpetuating agency culture can also impede organizational memory, and make it difficult for an agency to adapt to unfamiliar circumstances. ${ }^{69}$ In addition, culture encourages suspicion of bureaucratic forces that operate beyond the agency's borders. An agency with a strong culture is able to resist legislative decrees and broad policy initiatives, and pursue goals that are contrary to what the President and other high officials intended when making a decision. 'Sufficient differences in bureaucratic culture', Drezner argues, 'lead agencies to distrust the ability of other institutions to make any contribution to foreign policy' ${ }^{70}$

Each agency, moreover, has its own nomenclatures and lexicon, which can result in a breakdown in communications with outsiders. Differing agency cultures prompt vastly different, often conflicting, responses to the same situation. An agency's culture frequently prompts US officials to respond as their agency expects, rather than as the situation requires. At the implementation stage in particular, an agency's decisions are influenced by its culture. Many officials receive vague direction from their superiors and are instead guided by embedded agency culture and norms. Indeed there is often little oversight of their activities. The task of monitoring all activities within even a single department is staggering. Secretary of State Rusk informed the Jackson Subcommittee in 1963 that he only saw '20 or 30' of the 1,300 incoming State cables each day, and 'perhaps 6' of the outgoing ones. A large volume of bureaucratic traffic increases the capacity of agency cultural norms to determine the specific details of the policy process, and therefore decreases the ability of outside forces to influence agency behaviour. ${ }^{71}$

Bureaucratic interests, perception and culture operate within a broader constellation of power. Power is here understood in Weberian terms as, 'the probability that one actor within a social relationship will be in a position to carry out his own will despite resistance, regardless of the basis on which this probability rests'. ${ }^{72}$

67 Destler, Presidents, Bureaucrats and Foreign Policy: The Politics of Organizational reform, 38.

68 Charles Frankel, High on Foggy Bottom: An Outsider's Inside View of the Government (New York: Harper \& Row, 1969), 30.

69 Welch, "The Organizational Process and Bureaucratic Politics Paradigms: Retrospect and Prospect", 140.

70 Drezner, "Ideas, Bureaucratic Politics, and the Crafting of Foreign Policy", 737.

71 Halperin, Bureaucratic Politics and Foreign Policy (1974), 51.

72 Weber, Economy and Society, 53. 
The 'actor' here can be an individual, a bureaucratic agency or a state. The successful deployment of power can be based on either compulsion or persuasion, hard or soft power.

In the US foreign policy bureaucracy, agencies, factions and individuals seek to obtain and project power, usually against the resistance of others. Each party constantly attempts to increase its strength vis-à-vis other elements of the bureaucracy. Schilling compares this to diplomatic struggles between contending national states, where each intends to isolate the other, secure alliances, and influence neutral parties. He considers such machinations to be inevitable due to the fragmented power structure of the US system. ${ }^{73}$ The role of power within the paradigm of bureaucratic politics, however, is complex, ambiguous and difficult to evaluate.

Despite this, one way to measure power is to focus on hierarchy. According to Allison, power within US foreign policy is not evenly distributed. Rather, he argues that there is a set hierarchy in respect to each issue, with power concentrated in particular sections of the bureaucratic hierarchy. He compares this to a game of chess: 'The hierarchy structures the game', in which players with a mixture of conflicting preferences have 'unequal power over particular pieces'. ${ }^{74}$ Other scholars agree that the distribution of power is relatively stable, and is attached to and flows from formal positions within a bureaucratic hierarchy. 'Battles may be fought anew each time', Freeman writes, but 'gains flow in a persistent, if slightly wavering, direction'. ${ }^{75}$ When connected to an established hierarchy, the projection of power is determined by capacity, capability and prestige. These in turn are influenced by depth of resources and control over information. The US military and the State Department, for example, are more powerful in the realm of foreign policy than USAID or the Department of Agriculture.

When understood in the terms outlined above, hierarchy alone cannot account for the complex nature and distribution of power. Bureaucratic politics literature that focuses mainly on hierarchy has been criticized for saying little on how a stable hierarchy is maintained in respect of specific policy decisions and their implementation. Such arguments have merit. Agencies and factions that suffer 'numerical or status disadvantage vis-à-vis more dominant bureaucratic players', ${ }^{76}$ have little influence over the broad contours of foreign policy, but may have considerably more influence around a specific issue. The CIA, for example, has the power to dominate foreign policy issues linked to intelligence and more recently counter-terrorism. Similarly, as the Navy specializes in maritime warfare, neither the Defence Department, nor the Office of Management and Budget, are able to dictate its force posture. ${ }^{77}$

73 Schilling, "The Politics of National Defence".

74 Allison, Essence of Decision, 162-168.

75 Lawrence Freeman, "Logic, Politics and Foreign Policy Processors: A Critique of the Bureaucratic Politics Model”, International Affairs, 52 (1976), 434-449.

76 Kaarbo, "Power Politics in Foreign Policy: The Influence of Bureaucratic Minorities", 68.

77 Rhodes, "Do Bureaucratic Politics Matter? Some Discomfiting Findings from the Case of the US Navy", 18. 
For US officials also, power cannot be simply read off the formal hierarchy of authority and jurisdiction. Personal skill, reputation and relationships are also extremely relevant. Power is, therefore, associated with a US official's capacity to effectively manage and shape the resources, reputation and authority linked to this position. Here an individual's personality can have a powerful effect. According to Allison 'the hard core of the bureaucratic politics mix' is personality, formed in a crucible of organizational, national, domestic and emotional interests. ${ }^{78}$ Skill (or charisma) can help a US official overcome bureaucratic problems. For example, it is a skill to persuade others that a recommended course of action is in their own best interests. With this in mind, Clifford considers skill a crucial element in understanding who influences US foreign policy and why. Carafano agrees that the knowledge, skills and attributes of senior officials are vitally important. ${ }^{79}$

A final consideration when discussing power is that there are often multiple hierarchies that bear on a single foreign policy issue. For example, in a decision to go to war:

One action channel for producing US military intervention in another country includes a recommendation by the Ambassador to that country, an assessment by the regional military commander, a recommendation by the Joint Chiefs of Staff, an assessment by the intelligence community of the consequences of intervention, recommendations by the Secretaries of State and Defence, a Presidential decision to intervene, the transmittal of an order from the President through the Secretary of Defence and Joint Chiefs of Staff to the regional military commander, his determination of what troops to employ, the order from him to the commander of those troops, and the orders from that commander to the individuals who actually move into the country. ${ }^{80}$

These multiple hierarchies create multiple channels where power is exercised, which complicates the line of command. Richard Myers says that during the War on Terror it was never clear as to who was in charge of operations in Afghanistan and Iraq:

When I talked to civilian audiences they'd often say, 'Oh, well, the Secretary of Defence, Secretary Rumsfeld or Secretary Gates'. I would say, 'Oh, so he's in charge, he's responsible? What authority does he have over the State Department, National Security Council, Justice Treasury, Commerce, Homeland Security? What is his authority there?' The answer is that he has no such authority. So how can you put someone in charge if we're talking about all

78 Allison and Halperin, "Bureaucratic Politics: A Paradigm and Some Policy Implications", 48; Halperin et al, Bureaucratic Politics and Foreign Policy (2006), 16.

79 Clifford, "Bureaucratic Politics", 101; James Carafano, "Five Missteps in Interagency Reform And What to do about Them", PRISM, 2:3 (2011), 118.

80 Allison and Halperin, "Bureaucratic Politics: A Paradigm and Some Policy Implications", 45-46. 
the instruments of national power focusing to solve a problem when this person 'in charge' doesn't have complete authority? ${ }^{81}$

In summary, the power of agencies, factions and individuals within the foreign policy bureaucracy is related to hierarchy, but is projected through an amorphous blend of resources, capacity, prestige, skill and knowledge. Furthermore, characteristics such as the attitude and character traits of US officials may determine whether they have the power to overcome or compound bureaucratic hurdles.

\section{Conclusion}

This chapter suggests that the rational actor model is an inadequate starting point for understanding US foreign policy formation and implementation, in general and in Afghanistan. It takes little account of the ways in which different bureaucratic interests and agendas frustrate the will of political decision-makers, or of the unintended consequences of power struggles within the bureaucracy. One approach that partly overcomes these weaknesses is that of the so-called Carnegie school of Graham Allison and his fellow travellers, who developed important insights into how bureaucratic politics impacts on US foreign policy. The model that was constructed here builds on the insights of that school of thought while avoiding some of the pitfalls and suggests that bureaucratic politics can be usefully analysed through the lens of bureaucratic interest, perceptions, culture and power, which together enable and constrain actors with the US foreign policy bureaucracy. The heuristic value of this approach, however, can only be determined by putting it to work on a concrete case. In Part II therefore, the model elaborated here is used to try and come to grips with nation-building in Afghanistan. 



\section{Part II}

US Nation-Building in Afghanistan 



\section{The US Foreign Policy Bureaucracy and Nation-Building in Afghanistan*}

The contemporary US foreign policy bureaucracy is often described as a troika consisting of defence, development and diplomacy - the '3D's' in Washington parlance. This has been interpreted to mean that each foreign policy issue falls under the authority of either the military establishment, USAID or the State Department. Nation-building, however, does not unambiguously fit within the jurisdiction of any of the three realms. As Bowden notes, it 'has elements of each', but is 'exclusively none of them'.

Despite or perhaps because of this, nation-building would become something of a shared undertaking in Afghanistan, once it became clear that the 'shock and awe' of the initial military campaign would be insufficient to stabilize the country. The overarching aim of nation-building, in so far as there was one, was to project US power in order to secure political stability and economic development, coupled with the pretence of US-style democracy. This was encapsulated in various documents, including the Quadrennial Defence Reviews, the National Security Strategy, the State Department's Transformational Diplomacy Initiative and USAID's Fragile State Strategy. ${ }^{2}$ But beneath the veneer of common cause, there were serious fractures and problems. This chapter provides a general backdrop to these problems, as a primer for the more specific, issue-focused chapters that follow. It describes an approach to nation-building that was chaotic and disordered, which was driven by both inadequate leadership and bureaucratic factions with different interests, perceptions, cultures and power.

* Some sections of Chapter 4 appeared in "Divided We Stand: The US Foreign Policy Bureaucracy and Nation-Building in Afghanistan", International Peacekeeping 22:3 2015, pp. 205-229. Reprinted by permission of Taylor and Francis group - http://tandf.co.uk.

1 Commission on Wartime Contracting, An Urgent Need: Coordinating Reconstruction and Stabilization in Contingency Operations, Commission on Wartime Contract (Washington DC: 2010), 11.

2 Susan Rice, "The New National Security Strategy: Focus on Failed States", Brookings Policy Brief Series, February, 2003, http:/www.brookings.edu/research/papers/2003/02/terrorism-rice (accessed 3/5/2010); Condoleezza Rice, Transformational Diplomacy, Speech delivered at Georgetown University, January 18, 2006, http://2001-2009.state.gov/secretary/rm/2006/59306.htm (accessed 7/10/2011); Department of Defence, Quadrennial Defence Review Report, February 6, 2006, http://www.Defence.gov/pubs/pdfs/qdr20060203.pdf (accessed 7/10/2011); USAID, Fragile States Strategy, January 2005 http://pdf.usaid.gov/pdf_docs/PDACA999.pdf (accessed 8/10/2011). 
The chapter proceeds by first considering President George W. Bush's relatively disinterested attitude to nation-building in Afghanistan, which enlarged the scope for bureaucratic manoeuvring and power plays. It then outlines the roles that the military establishment, the State Department and USAID played in nation-building in Afghanistan. The 'Counter-Bureaucracy', a blanket term for Washington's regulatory bodies, is also examined. In the final part of the chapter, a series of inter-agency problems are discussed, which ultimately rendered the US nation-building project in Afghanistan incoherent.

\section{The Military Establishment}

The US military's response to a foreign policy issue is shaped by its perception of how that issue fits within the paradigm of national security. It is deeply reluctant to stray from its primary purpose: the enforcement of national security through violence. In a description that is as valid today as when it was first written, Hilsman writes that the US military establishment is, 'extremely conservative, nationalistic, aggressive, power oriented and simplistic'. This ensures that its reflexive response to most issues is to 'resort to crude force'. Warfare is the foundation of the military establishment's culture and 'the peculiar skill of the military officer'. ${ }^{3}$ To suit this agenda, each branch of the US military has strict chains of command and regimented behavioural norms. As a result, US soldiers, along with civilian officials at the Department of Defence, respond to foreign policy problems by following military nomenclature and certain combat-oriented routines. This was illustrated in the invasion of Afghanistan.

The military establishment and its civilian officials were central in the decision to invade Afghanistan and in its execution. Once it became clear that $\mathrm{Al}$ Qaeda was responsible for the attacks on the Twin Trade Towers and the Pentagon, the Taliban were given an ultimatum by President George W. Bush: 'hand over the terrorists, or . . . share their fate'. ${ }^{4}$ The Taliban refused to comply with that demand, which resulted in Operation Enduring Freedom being unleashed in October 2001. The invasion deployed CIA and Special Forces teams to establish targets for the US Air Force. ${ }^{5}$ They were assisted by the Northern Alliance, a loose conglomerate of anti-Taliban militia. The Northern Alliance was bribed

3 Roger Hilsman, The Politics of Policy Making in Defence and Foreign Affairs (Lanham: Prentice Hall, 1990), 203; Michael Meese and Isaiah Wilson, "The Military: Forging a Joint Warrior Culture", in Roger George and Harvey Rishikof, The National Security Enterprise: Navigating the Labyrinth (Washington DC: Georgetown University Press, 2001), 117-139; Samuel Huntington, The Soldier and the State: The Theory and Politics of Civil-Military Relations (Cambridge: Harvard University Press, 1957), 11.

4 Robert Draper, Dead Certain: The Presidency of George W. Bush (New York: Free Press, 2007), 156.

5 George Tenet, At the Center of the Storm: My Years at the CIA (New York: Harper Collins, 2007), 175. 
with money, weapons and other incentives to fight for the US cause. It substituted for a substantial US ground presence, because the military establishment in general, and the Defence Secretary in particular, was disinclined to commit large numbers of US troops.

Rumsfeld made it clear that it was not in the interests of the US military to ' $g o$ in with large conventional forces'. ${ }^{6}$ Instead, the US adopted a strategy that involved a minimal investment of manpower for maximum reward. The removal of the Taliban and the capture of Osama bin Laden and other members of Al Qaeda's leadership were the primary objectives. The military had no intention of committing to a protracted occupation of Afghanistan. The 'top priority is shaking Bin Laden's tree', Rumsfeld said, 'we're not invading; we're not going to stay'. George Tenet, the CIA Director, confirmed that, 'We are not invading ... we are not occupying, Mullah Omar betrayed the Afghan people. He let in these outsiders. That's the problem'. During the invasion and immediately thereafter, President Bush gave a relatively free hand to the Department of Defence (DoD) and its outspoken Secretary, Donald Rumsfeld. When he declared the War on Terror, Bush had told Rumsfeld that 'the ball will be in your court'. ${ }^{7}$ Rumsfeld accepted the cultural precepts of the military establishment, but he had a peculiar perception of how its interests were best served. After adopting the position of Defence Secretary he was determined to apply structural changes to the military apparatus. His agenda could essentially be reduced to a single word: 'transformation'. Rumsfeld considered the US military an outdated creature of the Cold War, which was unnecessarily slow and troop heavy. To transcend these supposed problems he advocated a reliance on precision weaponry and information technology, defined not by size, but instead by mobility and speed. He argued that military power was needed 'to help discipline the world', and that a high-tech, mobile fighting force would make that possible. ${ }^{8}$

By organizing the invasion of Afghanistan, Rumsfeld was able to test the validity of his assumptions. In a significant role change from his predecessor, he conversed daily with Central Command (CENTCOM) commander General Tommy Franks, in order to pilot the invasion in the direction he had chosen. Rumsfeld also took the Pentagon press podium each day, while General Richard Myers, the Chairman of the Joint Chiefs, stayed in the background 'saying little, looking on as though he had been reduced to serving as a minor spear-carrier'. ${ }^{\prime}$

6 Geoffrey Wawro, Quicksand, America's Pursuit of Power in the Middle East (New York: The Penguin Press, 2010), 494.

7 Woodward, Bush at War, 102-130 and 19.

8 Alexander Moens, The Foreign Policy of George W. Bush: Values, Strategy and Loyalty (London: Ashgate, 2003), 91; Phyllis Bennis, US Foreign Policy and the War on Terrorism (New York: Arris Books, 2003), 86.

9 James Mann, Rise of the Vulcans: The History of Bush's War Cabinet (New York: Viking, 2004), 306. 
In National Security Council meetings, meanwhile, the military establishment had the power to dismiss the reservations of the civilian agencies. Pentagon officials advocated combat-minded solutions, but ignored Afghanistan's political problems. The ability of the military establishment to overshadow diplomacy represented a paradigm shift from the 1990s. In a post-9/11 epoch, Ahmed Rashid observes, diplomacy became 'the prerogative of the Department of Defence . . . rather than the domain of the State Department'. ${ }^{10}$ Owing to the unilateral and expeditionary nature of the invasion, the Pentagon tolerated the State Department's overtures to the international community, but it did not allow it to circumscribe its invasion strategy. From the perspective of the military establishment, an international coalition was convenient but far from necessary, despite NATO invoking its mutual Defence clause for the first time in history. Apparently, 'the Pentagon had it well in hand'. Similarly, a United Nations role was only appropriate, according to a DoD Official, 'as long as it does not interfere with America's right to use military force'. In his now memorable aphorism, Rumsfeld announced that, 'The mission determines the coalition. The coalition must not determine the mission'. ${ }^{11}$

As a consequence of the military establishment's invasion plans, the bombing campaign involved little assistance from the international community. It was carried out effectively and efficiently, and produced an impressive display of firepower. All of the Pentagon's strategic targets were destroyed and it was (falsely) claimed that every target hit was a military one. ${ }^{12}$ Providing succour for Afghanis took a backseat to the bombardment of the country's already battered landscape.

When it was reported in the media that the bombing campaign had caused high numbers of civilian casualties and widespread population displacement, pressure from the White House encouraged the military establishment to consider the humanitarian repercussions of the invasion. It responded with ostentatious food drops that were clearly carried out for domestic political purposes rather than a genuine interest in helping Afghanistan's rural populace. From high altitude, the US Air Force sprinkled over one million aid packets across Afghanistan in what President Bush announced was 'the fastest delivery of humanitarian aid in the history of warfare'. The food drops were considered by experts to be expensive and unproductive. Astoundingly, aid packages were the same colour (yellow) as cluster bombs dropped by American B-52s, a mistake that could have been prevented had military procedure been modified to suit the task. The Pentagon, however, did not adapt its procedural norms in response to the debacle with the aid packages. The influence of military culture meant that it rejected changing the colour of aid

10 Rashid, Descent into Chaos, xlii.

11 Phyllis Bennis, US Foreign Policy and the War on Terrorism, 82; Colum Lynch, “Annan Urges Cautious Response", Washington Post, September 25, 2001; Julian Borger, "Powell Loses Power over Pentagon", The Guardian, December 11, 2001.

12 Bennis, US Foreign Policy and the War on Terrorism; BBC, "Aid Drops Target Civilians", BBC, October 7, 2001, http://news.bbc.co.uk/2/hi/south_asia/1585554.stm (accessed 26/06/2011). 
packages as an option, but it also refused to suspend the use of the yellow cluster bombs, as the success of the military campaign took precedence. ${ }^{13}$

Meanwhile, at the ground level, in the absence of a significant US presence, two infamous Afghan warlords, Abdul Rashid Dostum and Atta Muhammad Nur, occupied the city of Mazar-e-Sharif on 9 November. On 7 December, the Taliban lost their final stronghold in Kandahar Province. The removal of the Taliban had required only a few hundred CIA officers and members of the US Special Forces. But victory came at a price, as it bolstered the position of violent and avaricious Afghani figures who would later enter government and contribute to continued political instability.

During the invasion, from the planning stages to the occupation of Kabul, US policy toward Afghanistan did not evolve beyond a military operation set 'against a backdrop of Pentagon theorising and politics'. Short-term military operations, therefore, were conducted unilaterally and any broader involvement from the international coalition, the United Nations or the US civilian agencies was rejected by the Pentagon as unnecessary. Operation Enduring Freedom seemingly vindicated warfare based around Rumsfeld's 'lighter, smarter, more agile US forces that could do more with less'. The US military had succeeded in its initial goals, but without any deeper consideration of Afghanistan's political future. For the Pentagon, what happened next in Afghanistan was less important. On 16 December Rumsfeld who much like Afghanistan's warlords had solidified his position as a result of the invasion - claimed that Afghanistan was a done deal. But there were now other targets that beckoned: 'Your job is certainly not over', Rumsfeld told US soldiers, 'there are a number of countries that are known as being on the terrorist list'. George Tenet added that, 'Afghanistan was merely the opening act'. ${ }^{14}$

Even after the White House expressed a desire to pursue nation-building in Afghanistan, the military establishment's ability to adapt and embrace was circumscribed by its behavioural norms. Antipathy toward nation-building remained deeply embedded in the military's culture. This had been on display in Vietnam, Somalia, Bosnia and Kosovo and continued to resonate in Afghanistan. Misgivings about the humanitarian and political nature of the activity were compounded by the fact that the military perceived Afghanistan to be just one of a number of battlefronts in the Global War on Terror (GWOT). As a result, its preference was 'to prepare for major combat', a Senior State Department Official argues, 'and not to disperse their efforts in stability operations, which were regarded as of secondary importance and something that detracted from their primary mission'. ${ }^{15}$ For the military establishment, nation-building came second to the destruction of the enemies of the United States.

13 George Bush, Decision Points (New York: Random House, 2010), 198; Bennis, US Foreign Policy and the War on Terrorism, 149.

14 Wawro, Quicksand: America's Pursuit of Power in the Middle East, 496-499; Mann, Rise of the Vulcans, 309; Tenet, At the Center of the Storm: My Years at the CIA, 176.

15 Author Interview with a Senior State Department Official, Washington DC, April 15, 2012. 
The reluctance of the US military to support nation-building did nothing to curb its capacity to manipulate US policy toward Afghanistan. For example, it was able to steer inter-agency committees to focus 'exclusively on ensuring that the US military buildup in the region proceeded smoothly'. ${ }^{16}$ The US military framed budget battles in Congress almost exclusively around weapons procurement for the destruction of Al Qaeda strongholds in the Tora Bora Mountains and elsewhere.

Only once a violent Taliban-led insurgency emerged in 2004, did the military recognize that Afghanistan required a deeper commitment that went beyond simple combat operations. The significance of nation-building was then repeated regularly by the Pentagon until plans for a US withdrawal were announced in 2011. The rhetoric of the military leadership suggested that it had gained an appreciation of the complexities of nation-building and the need for a whole-of-government strategy. William B. Caldwell, a senior US military commander, made it clear that

The margin of victory will be measured in far different terms from the wars of our past. The allegiance, trust and confidence of the population will be the final arbiters of success. ${ }^{17}$

According to Robert Gates, who replaced Rumsfeld as Defence Secretary in 2006, an interest in 'reviving public services, re-building infrastructure and promoting good government [had] moved into the mainstream of military thinking, planning and strategy'. ${ }^{18}$ Military documents reflected this shift in attitude. The 2006 Quadrennial Defence Review proposed that officers of all ranks make efforts to collaborate with other US agencies, and encouraged them to assist civilian agencies in areas such as security, governance and reconstruction. Similarly, the Army Field Manual (FM 3-07) indicated that the US Armed Forces were mandated to provide 'requisite security and control to stabilize an operational area', which would build 'a foundation for transitioning to civilian control'. ${ }^{19}$

Despite this apparent renewed interest in nation-building, warfare remained the military establishment's chief concern. Beneath the rhetoric of inter-agency cooperation, the nomenclature and strategy of the military married nation-building to combat operations, and thus implanted it within the framework of counterinsurgency. The Counter-Insurgency Doctrine (COIN), which was spearheaded by a cadre of officers led by David Petraeus, centred upon winning the 'hearts and minds' of the Afghan populace - in essence, the pursuit of 'social work with guns'. ${ }^{20}$

16 James Dobbins, After the Taliban: Nation-Building in Afghanistan (Washington, D.C.: Potomac Books, 2008).

17 Bacevich, Washington Rules, 201.

18 Bacevich, The Limits of Power: The End of American Exceptionalism.

19 Wade Markel et al., Developing US Army Officers' Capabilities for Joint Interagency Intergovernmental and Multinational Environments (Washington DC: RAND, 2011), 36.

20 Bacevich, Washington Rules, 200-201. 
Previously a central component of US strategy in Vietnam, the concept of counter-insurgency was reinvigorated by the US military during the wars in Afghanistan and Iraq. COIN was codified in 2006 in Field Manual 3-24. In Afghanistan, the US-led International Security Assistance Force (ISAF) evoked counter-insurgency in a response to the increasing violent and powerful Talibanled insurgency. Although counter-insurgency efforts could be argued to have begun earlier, from 2006 onwards the ISAF made it clear that its main priority was to engage in counter-insurgency. Broadly stated, COIN doctrine stressed the need to protect Afghan civilians, eradicate insurgent leaders, and establish a legitimate and accountable Afghan government capable of delivering essential human services. The effectiveness of this doctrine was apparently confirmed through the 2007 troop surge in Iraq and subsequently identified by many US officials as a panacea for nation-building problems in Afghanistan. ${ }^{21}$

COIN also promoted the infallibility of military leadership to assuage conflict and violence. Many considered it to have failed in Afghanistan because it ignored the country's complex internal dynamics. It has been derided as armed nationbuilding, which misguidedly posed military solutions to complex problems and failed to ensure development that would benefit ordinary Afghans, but at the same time expected them to embrace the foreign occupation. US agencies and officials disagreed on counter-insurgency priorities, how it could be achieved and how it correlated with nation-building. A rift emerged between military intellectuals during strategy sessions in Washington. While some embraced the strategy, other military officials believed it detracted from the military's core policy objective in Afghanistan: the destruction of Al Qaeda. Along with US civilian agencies, elements of the military challenged the conception that the US military should spearhead nation-building through counter-insurgency. ${ }^{22}$

Although DoD reports recognized how important cooperation and commitment were for US nation-building in Afghanistan, they declined to mention how this could be achieved through COIN. ${ }^{23}$ Instead, year after year, the reports focused on the best way to overcome the Taliban-led insurgency. Bacevich considers COIN to be nothing more than a chimera that allowed, 'senior and civilian military officials to sustain the pretense of having reasserted a measure of control over a situation in which they exercised next to none'. He continues, 'Where it pretended to

21 Karl Eikenberry, "The Limits of Counter-Insurgency Doctrine in Afghanistan", Foreign Affairs, September/October (2013). http://www.foreignaffairs.com/articles/139645/karl-w-eikenberry/ the-limits-of-counterinsurgency-doctrine-in-afghanistan (accessed 1/09/2014)

22 Girardet, Killing the Cranes, 382; Colonel Gian Gentile, America's Deadly Embrace of Counter-Insurgency (New York: The New York Press: 2013); Eikenberry, 'The Limits of CounterInsurgency Doctrine in Afghanistan"; Colonel Gian Gentile, "Misreading the Surge Threatens US Army’s Conventional Capabilities”, World Politics Review, March 4, 2008, http://www.world politicsreview.com/articles/1715/misreading-the-surge-threatens-u-s-armys-conventionalcapabilities

23 Department of Defence, "Toward Security and Stability in Afghanistan, Report on Progress", Department of Defence, June 2009, Section 2.1, 20. 
speak most authoritatively, it managed to say next to nothing. There was lots of foam, but not much beer'. ${ }^{24}$

Notwithstanding the fact that the military's interest in nation-building was narrowly centred on its use as a tool to combat the insurgency, it cast a long shadow over the small US Embassy, skeletal USAID contingent, and other US civilian agencies that operated in Afghanistan. It had the money, resources and manpower to dominate nation-building activities. US soldiers functioned as veritable ambassadors to district and tribal leaders. Moreover, as conditions in Afghanistan continued to deteriorate, the military supplanted other government agencies in areas such as development and humanitarian assistance. Congress provided an abundance of funding for counter-insurgency, which enabled soldiers to undertake development initiatives such as schools and agricultural projects.

Rather than attempting to facilitate governmental cooperation, therefore, the military establishment replaced other US agencies. The Pentagon's Directive 3000.05 exemplified COIN's pervasiveness by creating a Deputy Secretary of Defence for Stability Operations, and a Defence Reconstruction Support Office to oversee its nation-building programme, separate from the rest of the US government. ${ }^{25}$ According to Directive 3005, which was implemented in November 2005, the military was mandated to fill gaps in capacity on the civilian side. The Directive indicated that the Pentagon had a requirement to provide skills for nation-building that were not present in civilian agencies.

The military establishment, like any other large organization, contains numerous parts and internal fault lines. Ideas on how best to pursue counter-insurgency and identify its relationship with nation-building varied, and areas of jurisdiction were sometimes unclear. Senior officials at the Pentagon exerted nominal control over the armed forces, but that relationship was much more complicated in practice. A gulf of understanding between US soldiers in the field and their commanders emerged as each group experienced the conflict in Afghanistan very differently. Ongoing intelligence and combat operations were juxtaposed with nation-building, which left soldiers with a 'Catch 22', where their role as a fighting force in an enemy combat zone competed with the auxiliary task of rebuilding a country and revitalizing its populace. By contrast, DoD officials and military commanders in Washington were primarily guided by more traditional cultural precepts and interests. ${ }^{26}$ Alternatively, the perspective of factions such as the National Guard and Corps of Engineers was that they were better suited

24 Bacevich, Washington Rules, 186 and 197.

25 "Nation-Building Elevated", The Washington Times, December 14, 2005. http://www.washing tontimes.com/news/2005/dec/14/20051214-124815-7913r/?page=all (accessed 30/11/2012)

26 Tim Kane, Bleeding Talent: How the US Military Mismanages Great Leaders and Why it's Time for a Revolution (New York: Palgrave Macmillan, 2012); Christopher Schanaubelt, "Complex Operations and Interagency Operational Art", PRISM, 1: 1 (2009), 44; Fredrick Smith and Franklin Miller, "The Office of the Secretary of Defence: Civilian Masters?" in Roger George and Harvey Rishikof, The National Security Enterprise: Navigating the Labyrinth (Washington DC: Georgetown University Press, 2001), 97-117. 
than regular US forces to handle nation-building tasks, due to their self-professed expertise outside of the paradigm of war-fighting. Mark R. Warneke, a Colonel in the National Guard, described how the electricians, carpenters, plumbers and police officers under his command had uniquely valuable skill sets that should not have been ignored by his colleagues at the Pentagon. ${ }^{27}$ The interaction of these competing factions combined with the military establishment's combat-minded culture and narrow interests to compromise its ability to engage in effective nation-building in Afghanistan.

\section{The State Department}

In contrast to the military establishment, the primary purpose of the State Department is to engage in diplomacy. Subtle, nuanced, consensus-building, the art of persuasion and negotiation, cultural sophistication and exemplary etiquette are used to interact with foreign governments in a way that no other branch of the US government can. ${ }^{28}$ The State Department's interests, therefore, are fundamentally linked to diplomacy, and it discourages any other agency's involvement in diplomatic relations with other countries. Its ingrained cultural traditions nurture the perception among its officials that change is to be resisted, and most individuals within the department prefer to inherit policy legacies than create their own. With this in mind, Scott considers it naive to expect 'bold and innovative policy from the Department of State'. ${ }^{29}$

The State Department's conservative approach to foreign policy facilitates bureaucratic obfuscation. It is slow to promote its interests because of complex procedural clearances that also reward its officials for 'paper-pushing'. For this reason, Rubin contends that its culture is characterized by 'a stubborn entrenchment of unimaginative careerism' ${ }^{30}$ Other government agencies describe the State Department as overly cautious and unimaginative, which determines that it is 'incapable of producing coherent recommendations or carrying out policy'. ${ }^{31}$ Power within the State Department is spread among various competing factions. Large and dispersed, it includes regional bureaus, embassies, and a headquarters in Washington. Roughly half of its officials operate within the nation's capital, while the rest reside overseas. Factionalism creates fiefdoms that are extremely protective of what they perceive to be their turf.

27 Larry Minear, The US Citizen-Soldier and the Global War on Terror: The National Guard Experience (Medford: Feinstein International Center, 2007).

28 Harry Kopp and Charles Gillespie, Career Diplomacy: Life and Work in the Foreign Service (Washington DC: Georgetown University Press, 2011), 2-3; Donald Warwick, A Theory of Public Bureaucracy (Cambridge: Harvard University Press, 1975), 30-32.

29 Andrew Scott, "The Department of State: Formal Organization and Informal Culture", International Studies Quarterly, 13 (1969), 2.

30 Barnett Rubin, Secrets of State: The State Department and the Struggle Over Foreign Policy (New York: Oxford University Press, 1987), 261.

31 Holbrooke, "The Machine that Fails". 
Notwithstanding the State Department's internal conflict, it fights ferociously against outside forces that seek to influence its agenda. A former Presidential staffer observes that State Department officials view the White House as 'a transient meddler in their business'. ${ }^{32}$ Executive appointees who were positioned within the State Department itself have levelled similar criticisms. For example, John Galbraith, the US Ambassador to India, from 1961 to 1963, complains that there was 'a widespread feeling . . . that God ordained some individuals to make foreign policy without undue interference from Presidents and politicians'. He claims that because the State Department is so parochial and territorial, the only way in which he could successfully advise President Kennedy was to bypass it entirely. ${ }^{33}$ This narrow parochialism and resistance to the interference of outsiders was also expressed in Afghanistan.

Before the invasion of Afghanistan, the State Department relished the opportunity to act as diplomatic mouthpiece for the United States. Global solidarity was widely considered a 'silver lining to the cloud of September 11', and provided an opportunity for animosity toward America's hegemonic position to be replaced with international cooperation. ${ }^{34}$ Coalition-building was pursued by Colin Powell in September 2001, as the War on Terror took shape. The US Secretary of State was 'engaging with the world' in order to form 'a long-standing coalition'. ${ }^{35}$ Moreover, the State Department laboured assiduously to obtain the support of Afghanistan's neighbours for the impending invasion. Of utmost importance was Pakistan, and US officials were able to secure the backing of Pakistani President, Pervez Musharraf. Meanwhile, through diplomatic overtures to Russia, the State Department carved a path for friendly relations with the Central Asian Republics and facilitated a US-alliance that included the major European powers. Bush said that it 'had done an impressive job' rallying the global community to the US cause. ${ }^{36}$ When it came to the question of Afghanistan's future, however, the State Department was less organized. Embedded interests, idiosyncratic perceptions, cultural conservatism, and factional diversity converged to influence its approach to nation-building.

The first indication of the State Department's plans for nation-building in Afghanistan was a series of meetings conducted in late September 2001by Richard Haas, the Senior Director for Near East and South Asian Affairs. The meetings advocated a political transition headed by the UN, and advised that the US commit to a strategy of 'nation-building lite'. ${ }^{37}$ Haas's cautious recommendations were not supported by the military establishment. For the military, diplomatic ties were only important in so far as they could facilitate the US invasion. Beyond that they had no purpose. Once military victory had been achieved in Afghanistan,

32 Ibid.

33 Destler, Presidents, Bureaucrats and Foreign Policy, 156-158.

34 Clyde Prestowitz, Rogue Nation: American Unilateralism and the Failure of Good Intentions (New York: Basic Books, 2003), 4.

35 Powell quoted in Woodward, Bush at War, 65.

36 Bush, Decision Points, 187.

37 Rashid, Decent into Chaos, 75. 
the White House and the US military considered it to be the State Department's responsibility to deal with the political fallout, and eschewed any deeper role in shaping Afghanistan's future. In other words, in the absence of interest from the White House or the military, the State Department was left with the responsibility of nation-building. Some of its officials embraced that obligation: 'We are looking at a defining moment, if only we will grasp the opportunity to shape a post-Taliban Afghanistan', one said. Another official argued that 'a US-led alliance could help reconstruct a new government, which could finally bring peace after 23 years of war'. Powell had grand ambitions for Kabul. He saw it as an, 'international city, symbol of a united Afghanistan'. But he was also careful to stress that Afghanistan would not be 'a huge Marshall Plan kind of investment'. ${ }^{38}$

As Afghanistan's tortured history suggests, the challenge of achieving stability was far more demanding than the rhetoric of the State Department suggested. In order to meet that challenge, Steven Hadley, the Deputy National Security Advisor, headed a diplomatic effort to find someone else to conduct nation-building. Once again, the State Department exhorted the international community to provide economic support in the form of large but ambiguous monetary commitments, and convinced the United Nations to steer the political transition.

This resulted in the Bonn Conference in December 2001, which was held in order to navigate a complex blend of political, economic, developmental, humanitarian, security and legal issues. The two US representatives at the conference, Richard Haas and James Dobbins, were both career diplomats. A Senior State Department Official claimed that he was given a free hand to represent the United States, without the interference of other bureaucratic forces: 'The State Department wasn't trying to influence the conduct of the military campaign', he asserts, and 'the Pentagon wasn't trying to influence the diplomacy in a substantial way'. He continues, 'At that point, I had encountered no interagency policy differences of any consequence, and Hadley and Rice were on Board for a UN-sponsored conference to form the next Afghan government'. ${ }^{39}$

The Bonn Agreement that emerged from the conference provided the foundation for a multi-ethnic representative government. An Interim Authority was inaugurated on 22 December with Hamid Karzai as its chairman. Karzai was nominated by the State Department as the most suitable choice for head of the interim administration, and he was closely linked to its policies in Afghanistan thereafter. There were, however, two significant problems with the Bonn Agreement. On the one hand, it was conducted in complete isolation from the US wareffort, and thus failed to clarify how the military campaign would coordinate with the nation-building process. The only input the military establishment had during the talks was to insist that the Northern Alliance - many of whom were known warlords - were given positions within the new Afghan government. For

38 Ahmed Rashid, "A Path Paved with Pitfalls", Far East Economic Review, October 4, 2011; Draper, Dead Certain, 231; Rashid, Descent into Chaos, 12.

39 Author Interview with a Senior State Department Official, Washington DC, April 15, 2012. 
the Pentagon, it seemed, the legitimacy of a given actor was premised on their support for the United States. It was 'not whether you have guns, nor whether you use them against people, and certainly not that you use them for personal gain', but rather how a given actor helped with the mission against Al Qaeda and the Taliban. ${ }^{40}$ Although the State Department did not agree with legitimizing these actors, it was powerless to prevent the military from adopting that posture, especially after it had just spearheaded a successful invasion.

On the other hand, the Bonn Agreement divided responsibility between the US and its allies. Although the United States formed the bulk of the military presence, most aspects of nation-building were outsourced to other countries. Because the State Department had focused on its traditional diplomatic role, it neglected the issues of security and development. Development may have been more of a priority had USAID and the United States Department of Agriculture been consulted, but their input was negligible. Instead, the conference determined that the US would focus exclusively on the construction of Afghanistan's army, while responsibility for the creation of a police force was given to the Germans and counternarcotics to the British. Judicial reform went to the Italians and disarmament, demobilization and reintegration to the Japanese. ${ }^{41}$

In essence, it was an ad hoc allocation of responsibilities that bore no resemblance to each country's area of expertise. Nor did it represent a comprehensive, organized front within the US government, despite claims to the contrary from State Department officials. The delegation of authority and deadlines of the Bonn Agreement exemplified a preference for a short-term commitment. It included ambitious timetables that outlined progress indicators. This was acceptable to the State Department but antithetical to USAID's development philosophy. Consequently, and against what nation-building experts considered best practice, the US mission had no clear allocation of responsibility or established lines of authority between different US agencies. The only firm understanding was that the United States would commit to training the Afghan National Army (ANA), but even the way in which this would be approached was unclear. Nonetheless, from a diplomatic perspective the State Department considered Bonn to be a success. ${ }^{42}$

Some analysts believe that the State Department was the most appropriate organ to realize the nation-building aims of the Bonn Agreement. ${ }^{43}$ But in the years that

40 Chris Johnson and Leslie Jolyom, Afghanistan: The Mirage of Peace (London: Zed Books, 2005), 33.

41 United Nations Assistance Mission in Afghanistan, Agreement on Provisional Arrangements in Afghanistan Pending the Re-establishment of Permanent Government Institutions, United Nations, December 2001, http://unama.unmissions.org/Portals/UNAMA/Documents/Bonn-agreement.pdf (accessed 22/01/2011).

42 Phillip Kurata, "Former US Envoy to Afghanistan Reviews Bonn Agreement Success", IIP Digital US Embassy, October 5, 2006, http://iipdigital.usembassy.gov/st/english/article/2005/10/2005100 6144849cpataruk0.9693109.html\#axzz2sE1QNmh1 (accessed 23/9/2012)

43 Patrick Stewart and Kaysie Brown, Greater than the Sum of its Parts? Assessing "Whole of Government” Approaches to Fragile States (New York: International Peace Academy, 2007), 36. 
followed, a State Department official with experience in Kabul notes that 'there was no real effort to try to define or articulate a national strategy' and 'no pressure to coordinate' ${ }^{44}$ Instead, the State Department fragmented into a number of different factions, and an overlap in their respective responsibilities characterized its involvement. Powell's military background meant that he was unfamiliar with the culture, hierarchy and interests of the State Department, which circumscribed his ability to organize it, or facilitate cooperation with other US agencies. Furthermore, deeply embedded cultural norms made it difficult for development experts or any other specialists to steer the State Department toward the unfamiliar shore of nation-building in Afghanistan. Therefore, little was done to redress the disorganization and internecine conflict between factions within the department and with other civilian agencies. These conflicts only intensified over time.

The State Department's mission in Afghanistan was divided haphazardly between Bureaus, Planning Divisions, the Embassy in Kabul and factions in Washington. To begin with, Chistina Rocca, the Head of the Bureau of South Asian Affairs, formed one part of the apparatus, but 'lacked the staff, the budget, and the authority to handle the myriad issues associated with Afghanistan's liberation and reconstruction'. ${ }^{45}$ Richard Haas led another faction. His role as the Coordinator for the Future of Afghanistan placed him at the Head of the State Department's Policy Planning division (DPP). The DPP had more varied expertise, but still 'lacked authority to instruct overseas missions or to conduct relations with foreign governments . . . having even less operational capacity than the South Asian Bureau' ${ }^{46}$

The US Embassy in Afghanistan was another competing power centre. As head of each US Embassy, the Ambassador is considered by the Foreign Affairs Handbook to be prestigious and influential - a fountainhead for the direction and coordination of US policy in the country to which he is deployed. However, one former diplomat argues that,

It would be manifestly impossible for a chief of mission to accomplish, as ambassador, anything in the way of business with the government to which he is accredited, if in addition he tried personally to supervise all the programs operated in the name of the American government within his bailiwick. ${ }^{47}$

This observation reflected the situation in Afghanistan where each US Ambassador had some authority, but neither financial control nor executive license to oversee nation-building. In reality, the Ambassador held no sway over other US

44 Author Interview with a Senior State Department Official, Washington DC, April 15, 2012.

45 Dobbins, After the Taliban: Nation-Building in Afghanistan.

46 Ibid.

47 Ellis Briggs, "Farewell to Foggy Bottom: The Recollection of A Career Diplomat" in Morton Halperin, Bureaucratic Politics and Foreign Policy (Washington DC: The Brookings Institution, 1974), 38. 
agencies or even factions within the State Department, which tended to pursue their own parochial interests. Competing bureaucratic hierarchies in Kabul were completely removed from the US Ambassador's chain of command, and many of them included private communication channels and separate headquarters.

To sum up, although the State Department was more familiar than the military with the diverse and complex considerations of nation-building in Afghanistan, its factionalism, preoccupation with diplomacy and animosity toward other agencies circumscribed its ability to play a leadership role.

\section{USAID}

When the United States Agency for International Development (USAID) was established in 1961, President Kennedy believed that he had created a separate agency to prevent development assistance from being marginalized by the military, or subjected to the bureaucratic machinations of the State Department. ${ }^{48}$ As its name suggests, USAID is the international development wing of the US foreign policy bureaucracy. Technically it falls under the purview of the State Department, but it is, for all intents and purposes, practically autonomous.

While USAID considers national security and democracy as important as the rest of the government does, it maintains a unique developmental creed. This creed emphasizes the importance of local autonomy, community empowerment, and economic and political progress through long-term development projects, which involves building institutions that are self-sustaining and creating a productive relationship with local partners. ${ }^{49}$ To suit its interest in long-term development assistance, USAID has a nebulous and flexible hierarchy. Each and every one of its officials is an emblem for the interests of the whole agency, and he or she is given a higher degree of responsibility and power than the average US soldier or State Department official. According to Andrew Natsios, the USAID director from 2001 to 2006, it is 'not an overstatement to say that USAID staff of each mission is the program, providing technical expertise to design projects, advising government ministries struggling with policy reform, and helping with civil society organizations to implement their projects'.$^{50}$ The interests and culture of the USAID, therefore, combine with the autonomy its officials possess to foster the perception that it is more suited to spearhead overseas development than other US agencies.

Nation-building in Afghanistan presented USAID with an opportunity to secure a more powerful and prestigious position within the foreign policy bureaucracy. After the initial military intervention, a significant aspect of nation-building in

48 Destler, Presidents, Bureaucrats and Foreign Policy: The Politics of Organizational Reform, 195.

49 Bernard Wood, "Development Dimensions of Conflict Prevention and Peace-Building: An Independent Study Prepared for the Emergency Response Division", United Nations Development Program, 2003, 11.

50 Andrew Natsios, "USAID in the Post-Cold War World", Foreign Service Journal, June (2006), 23. 
Afghanistan involved development projects in various issue areas. As a result, USAID's power increased in terms of both resources and responsibility. Its budget almost tripled from $\$ 10$ billion in 2001 to $\$ 27.5$ billion in 2005 . But this must be viewed in a context of longer term decline. USAID declined from 4,300 officers in 1975, for example, to just 1,300 in 2010. In the 1990s alone, the agency had lost approximately 35 per cent of its permanent staff base. When nation-building in Afghanistan began, it had only 16 full-fledged agricultural experts and 6 engineers, woeful figures compared to the hundreds who were employed in the 1980s. Even as funding for nation-building activities increased, USAID's staff numbers increased at a much slower rate. The number grew by only 100 from 2001 to 2006, which led one commentator to dismiss it as no more than 'a check writing agency'. ${ }^{51}$ Another outcome of the gulf between funding and manpower was that the majority of USAID's projects in Afghanistan were outsourced to local or US civilian contractors. The later straddled the border between the private and public realm, creating yet another disparate faction within the foreign policy bureaucracy.

The other US agencies seemed to have little understanding of USAID's lack of manpower. In the first few years of nation-building, Rumsfeld constantly asked Natsios why his agency had not mobilized in Afghanistan. The USAID director informed him that it had sent 120 people to the country, which equated to over 10 per cent of his entire staff. When hearing this, Rumsfeld was completely shocked that USAID only had a total of 1,100 officers. Irrespective of its decline in numbers, USAID perceived the reconstruction of Afghanistan to be its 'turf'. Natsios considered his officers to be closest to and most aware of the requirements of nation-building. He describes them as 'the real development experts', whose 'policy input serves as a check on Washington politics'. Similarly, USAID Deputy Administrator, Donald Steinberg, made it clear that USAID was 'best suited to bringing together the different elements of development'. When questioned whether or not USAID officials had the qualifications and talent to manage the funds they were given to pursue nation-building in Afghanistan, one Senior USAID Official confidently replied: 'of course they do, they've been doing it since the Marshall plan. We have millions of documents on nation-building efforts for 50 years'. 52

After 30 years of civil war, however, Afghanistan did not resemble the environment that USAID had experience operating in elsewhere in the world. Yet it continued to advocate long-term development projects in Afghanistan, akin to the ones that it had conducted in Africa and elsewhere. This highlighted the influence of agency culture on its policies. USAID was under the impression that it knew the correct path to successful nation-building in areas such as security,

51 David Rohde and Carlotta Gall, "Delays Hurting US Rebuilding in Afghanistan", New York Times, November 5, 2005.

52 Andrew Natsios, "Five Debates on International Development: the US Perspective", Development Policy Review, 24: 2, 134; Author Interview with Donald Steinberg PRISM 3:2 (2012); Author Interview with a Senior USAID Official, Washington DC, April 19, 2012. 
infrastructure development, agriculture, governance and law and order. It was also interested in Afghanistan's 'absorptive capacity', which was the ability of Afghanistan to effectively utilize the money funnelled in from outside sources. But at the same time, it was not mindful of the unique challenges Afghanistan presented.

Not all of USAID's officials was as confident in its ability as Steinberg. One USAID official, for example, believed that the agency simply did not have the power, in terms of capability, resources and expertise, to spearhead nationbuilding in Afghanistan

USAID did not have the capacity in 2003 to organize, manage and implement a comprehensive state-building project in Afghanistan, absolutely not. To create the grants, contracts and agreements necessary to implement it all that capacity didn't exist. There wasn't the capacity to oversee the number and size of the contracts and grants that were going to be necessary in Afghanistan. There certainly wasn't the regional or national expertise, at least on the ground team. In a country in which you had sustained engagement such as Kenya or Nepal, USAID had a long-standing presence in the country; they have connections throughout the community. In Afghanistan, there were virtually no institutional operations. There was no on the ground capacity. So they had to be built from scratch and without the ability to surge, USAID was a much weakened player. ${ }^{53}$

USAID's perspective on how to pursue nation-building in Afghanistan also clashed with that of the rest of the foreign policy bureaucracy, which sought immediate results from nation-building projects, especially once the insurgency intensified after 2004. When it was under pressure to meet the timetables of the State Department and the military establishment, USAID continued to pursue its projects in isolation. ${ }^{54} \mathrm{~A}$ USAID Official notes a disconnect between his agency and the remainder of the US government, observing that there was 'no strategic plan' and that he had 'no idea' what US policy was. Another senior agency staffer recalls that, 'There was enormous disinterest and lack of support [within USAID] in working with military forces in Afghanistan'. ${ }^{55}$ Meanwhile, some officials within the State Department considered USAID's approach to be delusional and that the agency failed to recognize that it was operating in a hostile environment, which unlike its unilateral development projects in Africa, required inter-agency coordination. ${ }^{56}$

53 Author interview with a Senior USAID Official, Washington DC, April 23, 2012

54 Author Interview with a Senior State Department Official, Washington DC April 21, 2012.

55 Strimling Yodsampa, No One in Charge: A New Theory of Coordination and an Analysis of US Civil-Military Coordination in Afghanistan 2001-2009 (Unpublished PhD dissertation, Tuffings University, 2011), 100.

56 Author interview with a Senior State Department Official, Washington DC April 21, 2012. 


\section{The Counter-Bureaucracy}

The final component of the bureaucracy to be discussed is not an agency, but a loose assortment of organizations charged with regulatory and financial oversight over other wings of government. William Gormley refers to this amalgamation of agencies and committees as the "counter-bureaucracy". He describes the counter-bureaucracy as a "relatively durable government agency whose principle mission is to monitor, criticize, and improve the performance of other agencies'. It was erected by Congress 'as a response to bureaucratic growth, bureaucratic inefficiency and bureaucratic misconduct' ${ }^{57}$ In other words, the socalled counter-bureaucracy is meant to be a counterweight and overseer of the rest of the US government bureaucracy. Gormley's label is intentionally ironic, as instead of preventing bureaucratic obfuscation, the counter-bureaucracy adds to it.

The two flagship organizations within this framework are the Office of Management and Budget (OMB) and the General Accounting Office (GAO). The OMB is a strand of the executive branch. Originally called the Bureau of Budget, it was expanded by President Nixon into its current form. Although it claims to 'serve the President of the United States in implementing his vision', the construction of the OMB was at the behest of Congress to make sure that certain agencies spend only what it appropriates. ${ }^{58}$ The GAO, which describes itself as the 'congressional watchdog', was created in 1921 to support Congress in promoting increased performance and accountability through auditing. ${ }^{59}$ Since their inception, both the $\mathrm{OMB}$ and GAO have significantly increased in power, budget, scope and capacity. Additionally, the Officers of the Inspectors General (OIG), the Commission on Wartime Contracting, and the Special Inspector General for Afghanistan Reconstruction (SIGAR), all monitored nation-building in Afghanistan and have similar interests to the OMB and GAO.

On the one hand, the counter-bureaucracy is meant to help other US agencies perform as efficiently and effectively as possible. It places checks on profligate behaviour in order to promote good practice and prevent waste and duplication. Its principal role, in the opinion of many members of Congress, is to recognize and correct errors in other agencies'. On the other hand, US officials have described the counter-bureaucracy as insular, narrow-minded, inflexible and both distrustful and distrusted. The 'counter-bureaucrats' themselves are seen as paid public

57 William Gormley, "Counter-bureaucracies in Theory and Practice", Administration \& Society, 28:3 (1996), 276.

58 OMB Mission Statement http://www.whitehouse.gov/omb/organization_mission/ (accessed 22/06/2013); Gordon Adams, "The Office of Management and Budget: The President's Policy Tool", in Roger George and Harvey Rishikof, The National Security Enterprise: Navigating the Labyrinth (Washington DC: Georgetown University Press, 2001), 55-79.

59 GAO Mission Statement, http://www.gao.gov/about/index.html (accessed 22/06/2013) 
scolds, who are 'grumpy and tetchy'. Gormley criticizes the interests, culture and perceptions of the counter-bureaucracy and its officials:

In their quest for scandals, counter bureaucracies sometimes overlook deeper systemic problems. In their obsession with outputs, counter bureaucracies often neglect outcomes. In their zeal for compliance, counter bureaucracies may divert attention from performance. ${ }^{60}$

In the first few years of the Bush Administration, the counter-bureaucracy was hardly involved in Afghanistan, as the US nation-building budget was too small to provoke its interest. Once the insurgency precipitated a more comprehensive financial commitment, however, Congress subjected the endeavour to increased scrutiny, which encouraged the Counter-Bureaucracy to fill its investigative role. But the interests that drive the counter-bureaucracy were not entirely suited to the examination of nation-building in Afghanistan. Like the military establishment and the State Department, the counter-bureaucracy did not view nation-building as a complex task. Tangible indications of progress from US projects in Afghanistan often failed to materialize, at least in the form that the counter-bureaucracy demanded. As a consequence, the counter-bureaucracy perceived US agencies that operated within Afghanistan to be wasting money, and it was severely critical of the way that they undertook nation-building projects.

The culture of the counter-bureaucracy determined that such criticism focused upon metrics and accountability, rather than the merit of the projects themselves. It applied 'extraordinary layer-upon-layer of procedural requirements' to nationbuilding activities. ${ }^{61}$ The OMB, for example, required USAID, the State Department and the military establishment to report monthly on their disbursement rates. The GAO constantly called for more accountability in respect of funds. Thus the Program Assessment Rating Tool (PART) was established to monitor agency spending. It required USAID, the Department of Defence and the State Department to submit detailed reviews of their programmes. But the counter-bureaucracy itself did not have a completely free hand, as the mandates of its many committees and organizations were subject to periodic change by the congressmen or senators who directed their activities. The influence of Congress toward the counter-bureaucracy varied between its various elements. The GAO and SIGAR had significantly more autonomy than the OMB and the Commission on Wartime Contracting. This in part reflected a lack of clarity within the US government on what the objectives were in Afghanistan and how they could be achieved.

Considering the unique interests, perceptions, cultures and power of the bureaucratic factions involved in Afghanistan, it is in some ways unsurprising that the US was unable to establish overarching nation-building objectives. Usually one

60 Gormley, "Counter-bureaucracies in Theory and Practice", 294.

61 Andrew Natsios, The Clash of the Counter-Bureaucracy and Development, (Washington, D.C.: Center for Global Development, 2010), 3. 
agency takes the lead on a foreign policy issue, but nation-building did not lend itself so easily to unambiguous leadership: 'What that means', Bowden says, 'is that there is no single point of accountability'. ${ }^{62}$

The experience of a number of senior officials reveals how challenging it was to establish common goals. A Senior State Department Official contends that at the most senior levels the United States started with a flawed and unrealistic concept, because there was no way to coordinate between agencies. ${ }^{63}$ Another USAID staffer, who attended various inter-agency meetings on the topic of nation-building in Afghanistan, remembers that it was almost impossible to get the full array of US agencies behind the same prioritized set of goals and synchronize their timetables. ${ }^{64}$ Members of the military establishment had similar experiences. A US General posted in Afghanistan argues that there was no method of developing a common understanding of the mission or producing concrete objectives that transcended agency interests. ${ }^{65}$ A Senior Defence Department Official compartmentalizes the intragovernment divisions:

I said at the time that we were fighting these wars with $21 / 2$ agencies; the defence Department, there is a chunk of the State Department, a chunk of USAID and a chunk of everybody else, but our government as a whole was certainly not fighting the war. It was a very uneven distribution of responsibility and participation. ${ }^{66}$

Similarly, a former US Ambassador to Afghanistan recalls that each agency had a 'tendency politically to look at something not working as a failure rather than a learning point'. Each agency also possessed an 'inadequate understanding of how much one needs to adapt as one learns' ${ }^{67}$ In reference to just one budget submission, Ronald Neumann, US Ambassador to Afghanistan 2005-2007, says there was 'a long list of important tasks we should be doing, but no agreed sense of priorities' ${ }^{68}$ Another Senior State Department Official claims that the US bureaucracy became dysfunctional because 'responsibility was too dispersed' and 'there was too much overlap among competing fiefdoms'. ${ }^{69}$

An example of this overlap was Zakheim's appointment as Coordinator for Afghanistan. In addition to his responsibilities as Defence Department Comptroller,

62 Commission on Wartime Contracting, "An Urgent Need: Coordinating Reconstruction and Stabilization in Contingency Operations", Commission on Wartime Contract, 2010, 35.

63 Author Interview with a Senior State Department Official, Washington DC, April 30, 2012.

64 Author Interview with a Senior USAID Official, Washington DC, April 23, 2012.

65 Author Interview with a US Military Commander, Washington DC, April 29, 2012.

66 Author Interview with a Senior Defence Department Official, via telephone, Sydney to Colorado, July 15,2013

67 Author Interview with a Senior State Department Official, Washington DC, April 18, 2012.

68 Ronald Neumann, The Other War: Winning and Losing Afghanistan (Washington DC: Potomac Books, 2009).

69 Author Interview with a Senior State Department Official, Washington DC, April 15, 2012. 
he was selected to oversee the US mission, a position that he was neither qualified for nor suited to. ${ }^{70}$ Zakheim's title and role duplicated the one already held by Richard Haas, whom the State Department had appointed as the Coordinator for the Future of Afghanistan. Zakheim's appointment implied that the military either ignored or was ignorant of the State Department's command hierarchy. For Dov Zakheim, Defence Department Comptroller 2001-2004, the two overlapping appointments were 'a sorry testimony to the state of disarray that governed the administration's approach to Afghanistan once the military mission seemed to be under control'. He postulated that he was appointed because the interests of the military establishment and the White House had 'turned elsewhere'. ${ }^{71}$

In his biography Duty, Robert Gates observed the same problems that were described by the US officials who were interviewed for this study. According to Gates, 'muddled and overly ambitious objectives' combined with unclear lines of authority within the military establishment and confusion among the civilian branches as to what nation-building required. Gates was frustrated by the complex and entrenched nature of bureaucratic conflict, which was only exacerbated by personal animosity between officials and commanders and the mixed messages that he received about how nation-building in Afghanistan was progressing. ${ }^{72}$

Prominent individuals within the US bureaucracy, therefore, were largely in agreement that a framework for common goals was absent in Afghanistan. But each official's perception reflected his position within the foreign policy bureaucracy, and their explanation for the reasons behind such disarray varied significantly. Problems ran deeper than simply a failure to agree upon what nation-building in Afghanistan required. These problems can be usefully categorized as 'a lack of leadership', 'the military/civilian divide', 'the marginalization of USAID', 'counter-bureaucracy interference', and 'Washington vs. the field'.

\section{Inter-Agency Problems}

During President Bush's first year in office, there were clear indications of a particular foreign policy persuasion. He withdrew the US from the Kyoto Protocol, planned a high-tech missile Defence system, adopted a more confrontational stance toward China, and reversed diplomatic overtures to North Korea. Those moves not only exhibited a disdain for international law and institutions, but also a pivot from multilateral engagement to unilateralism. One aspect of this was a derisive attitude to nation-building. From the beginning of his Presidential campaign, Bush had said that he was against 'open-ended deployments and unclear missions'. He would later add that, 'I don't think our troops ought to be used

70 Dov Zakheim, A Vulcan's Tale: How the Bush Administration Mismanaged the Reconstruction of Afghanistan (Washington DC: Brookings Institution Press, 2011), 213 and 174.

71 Ibid., 171 and 174.

72 Robert Gates, Duty: Memoirs of a Secretary of War (Croydon: WH Allen, 2014), 205-210. 
for what's called nation-building' ${ }^{73}$ As if to add substance to his words, once he entered office PDD-56 - President Clinton's framework for military/civilian coordination in post-conflict states - was discarded.

Bush's hostile attitude to nation-building continued during and immediately after the invasion of Afghanistan. In a National Security Council (NSC) meeting in October 2001, he had asked 'who will run the country?' but was left without answers to his own question, at least initially. After the apparently spectacular success of the military intervention he reiterated his aversion to nation-building:

I oppose using the military for nation-building. Once the job is done, our forces are not peacekeepers. We ought to put in place a UN protection then leave ... there's been too much discussion of post-conflict Afghanistan. ${ }^{74}$

Bush's hostility towards nation-building combined with ignorance about how nation-building goals could be accomplished if the post-conflict situation demanded it. When asked whether the President understood the nation-building literature, a Senior USAID Official responded: 'absolutely not'. The White House, he continued, perceived nation-building to be 'little NGO projects doing good'. ${ }^{75}$ James Dobbins, Bush's special envoy to Afghanistan, suggested that after the invasion, 'the President and his closest advisers felt they were at the top of their game and that the hardest part in Afghanistan was over' ${ }^{76}$

In 2003, the White House committed economic, military and political resources to the invasion of Iraq, which prompted further disengagement from Afghanistan. Bush's preoccupation with Iraq drove a series of troop withdrawals from Afghanistan between 2004 and 2006. These were conducted against the advice of military officials in the field. David Barno, who was the Commander of the Combined Forces in Afghanistan from 2003 to 2005, argues that the President's actions 'altered the calculus of both our friends and adversaries across the region and not in our favor'. ${ }^{77}$

Bush did not visit Afghanistan until 2005. The only time he mobilized the US government towards a common objective in the country was by declaring a commitment to holding elections. The White House then extolled the success of Presidential and Loya Jirga elections, but ignored the instability, corruption and violence that marked Afghanistan post-Taliban political order. As a violent insurgency grew, the President continued to portray Afghanistan as a country with an improving security situation and the potential to transform into a thriving democracy. When the situation worsened considerably in the later part of Bush's

73 Rashid, Decent into Chaos, 1.

74 Woodward, Bush at War, 192-308.

75 Author Interview with a Senior USAID Official, April 19, 2012.

76 Dobbins, After the Taliban: Nation-Building in Afghanistan.

77 David Barno, "Fighting the 'Other War', Counter-insurgency Strategy in Afghanistan, 20032005”, Military Review, September-October (2007), 42. 
second term, the ambitious democratic programme was all but abandoned in deed if not rhetoric.

As senior US officials have highlighted, Bush failed to exercise any meaningful leadership over the foreign policy bureaucracy during this period, which could have potentially improved the situation in Afghanistan. A former US Ambassador, for example, argues that the ability of the Office of Management and Budget (OMB) to impede funding may have been overcome with pressure from the President. The National Security Council (NSC) could have and should have restricted OMB influence, but Bush did not place the NSC in a position to 'actually crack the whip'. ${ }^{78}$ A Senior State Department and USAID official believes that Bush had the opportunity to foster partnerships between agencies. He acknowledges the entrenched problem that divergent bureaucratic interests and culture presented, but argues that the President could have done a lot to mitigate them. ${ }^{79}$ Another State Department Official agrees that Bush had the ability to oversee the nation-building process and surmount bureaucratic hurdles in Afghanistan. He points to the previous CORDS programme in Vietnam, to which President Johnson attached a high priority. The Office of the Coordinator for Reconstruction and Stabilization (S/CRS) was created to promote coordination between agencies in Afghanistan and Iraq. But S/CRS was given little authority by the White House. ${ }^{80}$

According to another Senior State Department Official, Bush's attitude represented a serious dereliction of duty, for three reasons. First, the President was uninterested in exercising any discipline over outspoken members of the military establishment, such as Donald Rumsfeld and Paul Wolfowitz, who eschewed any responsibility for nation-building. Second, he asserts that bureaucratic problems were not insurmountable: 'If the effort had been perceived as a top priority by the President then people would have fallen in line' ${ }^{81}$ But without significant pressure from the White House, some issues that should have been solved fell prey to inter-agency conflict. The President was not interested in 'getting into detail or adjudicating interagency disputes', which 'led a lot of issues to fester, that should not have been allowed to fester' ${ }^{82}$ Third, he suggests that Bush failed to bestow authority on positions that were created to enhance collaboration. For example, James Dobbins chaired a multi-agency committee, but he had no power to influence the US military:

I had serious doubts about the workability of this arrangement. Only the White House could adjudicate differences between the State Department and DoD, of which there were bound to be many. Assigning State the lead for an

78 Author Interview with a former US Ambassador Washington DC, April 18, 2012.

79 Author Interview with a Senior USAID Official, Washington DC, April 23, 2012.

80 Author Interview with a Senior State Department Official, Washington DC, April 30, 2012.

81 Author Interview with a Senior State Department Official, Washington DC, April 15, 2012.

82 Ibid. 
activity where most of the assets were bound to come from DoD was in my view an abdication of White House responsibility. ${ }^{83}$

In contrast to Dobbins, President Bush had the power and authority to do significantly more in Afghanistan. But due to his style of leadership and lack of interest in nation-building he did little to mitigate intragovernmental conflict. Agencies, factions and strong-minded individual officials filled the vacuum left by Presidential neglect.

Another issue was that almost from the outset there was open hostility between the military establishment and the civilian agencies. The resources and capacity of the US military meant that it had more power, both in Washington and in the field, than any of the other civilian agencies. The Department of Defence (DoD) alone has over 3 million employees and a budget exceeding that of corporate giants such as Exxonmobil and Wal-Mart. In 2001, the US Armed Forces had more than 500,000 permanent soldiers, who could be swiftly deployed anywhere in the world. In comparison, the State Department, which is the largest and most influential civilian agency, had only 6,500 officers to draw upon for overseas engagement: 'As the military folks like to say on occasion', Barno writes, 'the entire State Department's worldwide deployable force ... would fit on one carrier battle group' ${ }^{84}$ The US Armed Forces sent over 1.5 million troops to Afghanistan and Iraq in the first five years of the War on Terror. This determined that a company commander in Kandahar Province was often in charge of more people than the US Ambassador in Kabul.

During a 2008 congressional hearing on nation-building in Afghanistan, Ambassador Karl Inderfurth, the Assistant Secretary of State for South Asian Affairs, described the imbalance between the military and civilian realms as 'the Popeye syndrome', whereby the strong right arm, the military, is fuelled by spinach and thus overshadows the anaemic left arm of the civilian agencies. In the same hearing, Barnett Rubin recognized a 'severe imbalance on the civilian side of our international relations apparatus'. ${ }^{85}$

The military's relationship with the civilian side of the US foreign policy bureaucracy evolved over time. Throughout the first term of the Bush Administration, Rumsfeld did not feel it to be in the military's interests to engage in nation-building in Afghanistan, and he actively discouraged cooperation with the civilian branches. This perspective translated into policy because of his control over the military realm. Rumsfeld made sure that there was no resistance to his authority within the officer corps: 'Confronted with contrary views, he moved quickly to crush them', Bacevich writes. A Senior State Department Official said

83 Dobbins, After the Taliban: Nation-Building in Afghanistan.

84 Committee on Armed Services, Assessment of US Strategy and Operations in Afghanistan and the Way Ahead, House Of Representatives, One Hundred Tenth Congress, Second Session Hearing, January 23, 2008, 24.

85 Ibid., 23-24. 
that he 'was the one running the show . . . there was no one in Rumsfeld's office who made policy except Rumsfeld' ${ }^{86}$ Rumsfeld's determination not to become involved in nation-building went unchallenged. The Commander of the United States Armed Forces, Tommy Franks, argued that it was his duty to unequivocally support the Defence Secretary. When Franks was asked by President Bush for his opinion on one of Rumsfeld's decisions he replied: 'Sir, I think exactly what my secretary thinks, what he's ever thought, what he will ever think or whatever he thought he might think' ${ }^{87}$

Rumsfeld's discouragement of a multilateral framework for Afghanistan provoked hostilities between the military establishment and the State Department. The animosity between Rumsfeld and Colin Powell, the US Secretary of State, was emblematic of this hostility. This inhibited cooperation in the field between military and civilian officials, which at least some military men viewed as problematic. But they were reluctant to speak out as they feared it would draw an unfavourable response from their obstinate superior. ${ }^{88}$ The one nationbuilding programme that Rumsfeld did support was the training of the Afghan National Army. Yet he did so only to free US troops for engagement in Iraq. In Afghanistan, meanwhile, he made it clear that he wanted as 'few people in uniform doing non-military functions' as possible. ${ }^{89}$ Rumsfeld's perception of military interests greatly compounded bureaucratic problems. As one Senior US Official remarks, 'the political leadership is designed to overcome that bureaucratic inertia, but instead of overcoming it, Rumsfeld's attitudes just tended to reinforce it'. ${ }^{90}$

Rumsfeld departed in 2006 as the Taliban-led insurgency intensified. As US casualties multiplied, intergovernmental cooperation toward nation-building was included as a part of the military establishment's new counter-insurgency platform. Robert Gates, Bush's second Defence Secretary, claimed that the solution to Afghanistan's problems lay in a comprehensive US commitment, and he adopted a conciliatory stance towards the new Secretary of State, Condoleezza Rice. But he later highlights Rice's frustration with the way in which the military command criticized the civilian branches:

Condi was very protective of State Department turf and prerogatives and she bristled quickly at any hint that State wasn't pulling its weight in the wars in Iraq and Afghanistan. More than once I got an earful about some general or admiral who had complained publically about the lack of civilian support. ${ }^{91}$

86 Bacevich, Washington Rules, 175.

87 Woodward, Bush at War, 251.

88 Neumann, The Other War.

89 Bill Gertz, "Rumsfeld Takes Dim View of US Peace-keeping Role", The Washington Times, February, 27, 2002.

90 Author Interview with a Senior State Department Official, Washington DC, April 15, 2012.

91 Gates, Duty, 99-100. 
Notwithstanding Gates's amiable disposition, a more violent conflict in Afghanistan was an opportunity for the military establishment to maintain a position of dominance within the realm of foreign policy and increase its already expansive budget. The budgetary imbalance between the military establishment and US civilian agencies was considered by Olson and Gregorian to be 'the biggest obstacle to a whole of government approach to failed states', where power asymmetry blocked productive dialogue. ${ }^{92}$ According to Burke, moreover, the military's attitude precluded any form of civilian influence or oversight. ${ }^{93}$

Although one US Official who was interviewed did not consider the military's heightened interest in nation-building to be 'nefarious or malign', many of his colleagues interpreted it as 'a conspiracy to take over the role of the State Department and USAID'. 94 'There was a great deal of bitterness between people at Defence and people at State', a Senior Defence Department Official, recalls. ${ }^{95}$ On trips to Washington, a US Military Commander found the 'blame game' between Defence and State at its most severe:

The war seemed to be between Defence and State and not the US and the Taliban. The bureaucratic turf battles back in Washington were tangible, they were extraordinary. ${ }^{96}$

Meanwhile, in the field, Neumann as the US Ambassador to Afghanistan, experienced how little proficiency the State Department and the military establishment had in working together. ${ }^{97}$ A Senior US Official reveals a deep gulf of understanding that was generated by agency culture:

The military criticizes the civilians for being too slow to move, too inclined to observe, and the civilians criticize the military for rushing forward with bad ideas. We teach quality military officers to try and get what they need, to go forward with what they've got usually in a fairly short term perspective. Civilians, whether AID or State are working in a world where a great many of the issues they handle are never going to be solved. So you spend a lot of your time trying to keep things from getting worse, trying to understand the political culture. ${ }^{98}$

In Afghanistan, by the time civilian officials came to understand how they wanted to proceed, 'the military establishment was ready to move forward and

92 Lara Olson and Hrach Gregorian, "Civil-Military Coordination: Challenges and Opportunities in Afghanistan and Beyond", Journal of Military and Strategic Studies, 10:1 (2007).

93 Edward Burke, "Leaving the Civilians Behind: The Soldier-Diplomat in Afghanistan and Iraq", PRISM, 1:2, 30-32.

94 Author Interview with a Senior State Department Official, Washington DC April 21, 2012.

95 Author Interview with a Senior Defence Department Official, Washington DC April 18, 2012.

96 Author Interview with a US Military Commander, Washington DC, April 29, 2012.

97 Neumann, The Other War.

98 Author Interview with a Senior State Department Official, Washington DC, April 18, 2012. 
they were bumping heads'. ${ }^{99}$ The civilian agencies were also under the impression that the Pentagon dismissed any nation-building initiatives that interfered with combat operations. For example, Dobbins claims that his efforts to put an end to indiscriminate bombing attacks by the US Air Force were ignored and met with hostility:

When I raised this issue and suggested that we look for some way to address the Afghans' expectations, my Defence Department colleagues responded with the ultimate bureaucratic stonewall. They told me, 'This is a legal, not a policy issue, and as such, we cannot even discuss it. Your lawyers will need to talk to our lawyers'. ${ }^{100}$

During a Congressional Committee Hearing, another Senior State Department Official said that the military's focus on immediate success in hot spots such as Kandahar resulted in merely a temporary calm, which failed to address the need for an overarching political, economic and development strategy in Afghanistan. ${ }^{101}$

Although the civilian agencies were quick to blame the military for its narrow focus, the military establishment claimed that the civilian agencies failed to modify their own behaviour to promote cooperation. The US military considered the State Department's handling of the nation-building process to be compromised by its internal disharmony, which consistently hampered nation-building initiatives and projects. ${ }^{102}$ Barno highlights the myriad of different authorities which were 'much more difficult to overcome' than within the military sphere. He characterizes the State Department's approach to nation-building in Afghanistan as 'akin to punching an adversary with five outstretched fingers rather than one powerful closed fist'. ${ }^{103}$ A Senior Defence Department Official, meanwhile, says that the military resented the fact that, in the absence of civilian capacity, it was the default option for 'just about everything',

Because the only guys that carried the guns were the military guys they were the guys upon whom everybody depended. There was uneasiness between the military folks who were bearing the overwhelming brunt of the Afghan mission, and everybody else who was clearly not doing the same. ${ }^{104}$

99 Ibid.

100 Dobbins, After the Taliban: Nation-Building in Afghanistan.

101 Strategy and Operations Committee on Armed Services, House of Representatives, Assessment of Security and Stability in Afghanistan and Development in US, One Hundred Tenth Congress, Hearing held on February 13, 2007, 10.

102 Francis Fukuyama, "Nation-Building and the Failure of Institutional Memory", in Francis Fukuyama (ed.), Nation-Building, Beyond Afghanistan and Iraq (Maryland: John Hopkins University Press, 2006), 9.

103 David Barno, "Fighting 'The Other War'”, 36.

104 Author Interview with a Senior Defence Department Official, via telephone, Sydney to Colorado, July $15,2013$. 
Zakheim's comment encapsulates the lack of enthusiasm for a whole-ofgovernment approach to nation-building within the corridors of a State Department that was not interested in providing officials to initiate cooperation with the military establishment. As a result, only 26 foreign policy advisory positions had been attached to the US military by 2009 . Even this was essentially a token gesture as most of those who had been sent were low level appointees: 'State doesn't exactly send it's A Team', one military commander admonished. ${ }^{105}$

According to one State Department staffer, the reason for the military/civilian divide in Afghanistan was that the current generation of bureaucrats and soldiers have no significant experience in operating in a military dominated framework. He claims that this explains why each US agency lacked the ability to co-exist and collaborate. ${ }^{106}$ Even the seemingly simple matter of providing security for US civilian officials to operate outside Kabul was compromised by traditional cultural precepts and competing agency interests. Only with the military's support could civilian officials operate in rural Afghanistan. But lawyers had to establish who would be responsible if someone was killed and there was disagreement over who would pay for the security detail. ${ }^{107}$ The question of whether the military would embrace the arrangement was for a long time left unanswered, as US officials struggled to figure out how it would provide transportation and assistance. Another point of contention was how and when civilian agencies would reimburse them for their services. ${ }^{108}$ Because of these bureaucratic issues, civilian officials were usually confined to Kabul.

The military establishment, meanwhile, had unrestricted access to the rest of the country. Although it had the power to enable civilian officials to operate in rural Afghanistan, it instead undertook tasks normally associated with the State Department (diplomacy), USAID, (development), the United State Department of Agriculture (agriculture), and the United States Department of Justice (counternarcotics). The military's engagement with those nation-building issues was often arbitrary, undertaken without the consultation of civilian officials, and usually displaying a combat-minded mentality. Even when there was a civilian presence in a province that the military operated in, the structure of the military command in Afghanistan determined that US soldiers were more likely to reject the unfamiliar and somewhat ambiguous strategies employed by the civilian agencies, in favour of the more regimented and straightforward objectives of their commanders. Likewise, military commanders were obliged to report through a strict military hierarchy that was disconnected from the US Embassy: 'As the US and coalition military commander', a US Military Commander explains, 'I reported to the commander of US Central Command, General John P. Abzaid and through

105 Burke, "Leaving the Civilians Behind: The Soldier-diplomat in Afghanistan and Iraq", 34.

106 Author Interview with a Senior State Department Official, Washington DC April 21, 2012.

107 Author Interview with a Senior State Department Official, Washington DC, April 15, 2012.

108 Ibid. 
him to the Secretary of Defence. Your system dictates your top diplomat and main military commander receive orders and report to different people'. ${ }^{109}$

The prominent place of USAID in Afghanistan engendered a different layer of conflict. The more powerful military establishment and State Department ordinarily tolerate USAID's divergent behaviour. In the past, both agencies have been prepared to cede jurisdiction on development issues to USAID that were beyond the parameters of their interests. But this only occurs when more important foreign policy matters are removed from the equation, which was not the case in Afghanistan due to nation-building's close association with the GWOT.

From the perspective of USAID, an inability to coordinate with the rest of the government stemmed from a lack of understanding outside the agency of how to implement projects and prioritize mission directives. For this reason, USAID struggled to accept the prerogatives of the State Department and the military establishment. Natsios considered doing so to be against the interests of his agency. He protested that projects that were conducted by the State Department and the military were out of tune with the 'developmental reality:' 'Military planners and to a lesser degree diplomats often take reconstruction as a literal concept: the physical rebuilding of infrastructure which, while a part of reconstruction, is not at the heart of it'. ${ }^{110}$

The military establishment interpreted USAID's stance toward nation-building as impractical and ineffective. Even at the beginning of the nation-building process, there was 'tremendous tension' between USAID and the US military. ${ }^{111}$ The Pentagon was frustrated by the fact that USAID had not mobilized quickly enough. Rumsfeld's reluctance to become involved in Afghanistan did not stop him criticizing the agency:

He kept saying 'Why don't you focus on the priority for Afghanistan'. I said 'Whose priority? That's your priority; I have the rest of the world to worry about'. ${ }^{112}$

USAID's preference for long-term projects, its lack of man-power and its hostile response to advice and criticism, fostered the impression among the military officials that it was 'totally useless and couldn't do anything on time'. ${ }^{113}$ Many DoD officials held a deep-seated resentment towards the agency. One Pentagon

109 Author Interview with a US Military Commander, Washington DC, April 29, 2012.

110 Andrew Natsios, "The Nine Principles of Reconstruction and Development", Parameters, Autumn (2005), 6. Andrew Natsios, "Time Lag and Sequencing Dilemmas of Post-Conflict Reconstruction", PRISM, 1:1 (2009), 63-75.

111 Author Interview with a Senior Defence Department Official, Washington DC April 18, 2012.

112 Author Interview with a Senior USAID Official, Washington DC, April 19, 2012.

113 Author Interview with a Senior Defence Department Official, Washington DC April 18, 2012. 
official who saw the merit of USAID's policies in Afghanistan was seen as betraying the interests of the military establishment:

I have scars on my back for defending USAID at the Pentagon. There was a time when people thought I had been infiltrated by the enemy. There was even talk of getting rid of me! ${ }^{114}$

Alternatively, the relationship between the State Department and USAID was characterized by indecision, rivalry and competing priorities, which precluded the two agencies from establishing a united nation-building front. ${ }^{115}$ The ambiguous nature of nation-building in Afghanistan did not offer promising conditions for overcoming that problem. Instead, hostilities intensified. When USAID argued with Afghani President Karzai over the suitability of certain development programs, for example, Karzai was supported by the State Department. The State Department considered itself to be the most suitable diplomatic conduit for US policy toward Afghanistan and resented the fact that USAID had spoken to Karzai without its permission. USAID, meanwhile, did not take kindly to the State Department's encroachment, and as a result of the two agency's incongruent priorities, 'what we came out with was a mess that was lamentable'. ${ }^{116}$ This type of conflict occurred over and over in respect of a number of different nation-building initiatives.

Although the military establishment, State Department, and USAID were divided on everything else, they were united in their resentment of the counterbureaucracy's interference. In fact, many US officials in the field perceived the counter-bureaucracy to be the single biggest constraint on their agency's ability to implement nation-building projects in Afghanistan.

From atop the ramparts of USAID, Natsios railed against the involvement of Washington's regulatory bodies. He describes the counter-bureaucracy as a 'behemoth of bureaucracies' and admonishes it for ignoring the key principle of development theory: 'that those development programs that are most precisely and easily measured are the least transformational, and those programs that are most transformational are the least measurable'. ${ }^{117}$ In sharp contrast to this maxim, he argues, an interest in recordkeeping and the documentation of project performance led the counter-bureaucracy to encourage rapidly measureable, but unrealistic, quantitative performance indicators. Adopting the role of psychologist, Natsios diagnoses the counter-bureaucracy with 'Obsessive Measurement Disorder'. 'Nothing could be further from good development theory and practice', he concludes. ${ }^{118}$

114 Ibid.

115 Renanah Miles, “The State Department, USAID, and Flawed Mandate for Stabilization and Reconstruction", PRISM, 3:1 (2011), 42.

116 Author Interview with a Senior USAID Official, Washington DC, April 19, 2012.

117 Andrew Natsios, "USAID in the Post-Cold War World", 24.

118 Natsios, The Clash of the Counter-Bureaucracy and Development, 13-40. 
Ken Schofield, the USAID Deputy Assistant Administrator, shared this opinion. He argues that the counter-bureaucracy hampered innovation in Afghanistan:

Almost eight months of every fiscal year are dominated by reporting and budget processes, leaving program and technical experts precious little time to design new programs and monitor the implementation of ongoing programs. ${ }^{119}$

The animosity USAID expressed toward the counter-bureaucracy was also common to other US agencies. Although some were more tolerant of SIGAR and the GAO than USAID, they saw the OMB as a threat to their agency's interests. The State Department, for example, believed that the auditing procedures and budgetary evaluations of the OMB were dysfunctional when applied to nationbuilding operations, while the US Embassy officials found that the fiscal road blocks the OMB erected were insurmountable. ${ }^{120}$ Even the more powerful military establishment often had its ambitions quashed by the OMB. One DoD official states that he constantly 'had to wrestle with OMB', which made obtaining resources extremely difficult. ${ }^{121}$

Part of the problem was that the OMB reviewed operations in Afghanistan in the same manner that it did domestic programmes in the United States: 'They were applying all of these bizarre standards to the program management system in Afghanistan', a Senior USAID Official recalls, 'it didn't work; we had yelling matches with people at OMB over this'. ${ }^{122}$ The OMB's opposition to budget measures proposed by the US diplomatic core in Kabul was described by a State Department official as 'specious arguments that went away a year later when we had a larger budget'. Platitudes or 'gamesmanship', he claims, were the only things that could 'keep them off your back'. ${ }^{123}$ Military officers also expressed frustration at the fact that the OMB placed legal requirements on spending 'a certain amount of your money until you can certify things that are virtually unverifiable'. ${ }^{124}$ This implies that the GAO, SIGAR and OIG were a nuisance that could be ignored, while the OMB was a more powerful force with the ability to disrupt an agency's plans.

Finally, there were problems between actors in the field and those in Washington. The embassy and military command in Afghanistan were power centres that held a different perception of nation-building priorities than Washington. Harr observes that 'operators in the field are prone to see Washington as a great

119 Ibid., 27.

120 Author Interview with a Senior USAID Official, Washington DC, April 23, 2012; Author Interview with a Senior State Department Official, Washington DC, April 18, 2012.

121 Commission on Wartime Contracting, An Urgent Need: Coordinating Reconstruction and Stabilization in Contingency Operations, 77.

122 Author Interview with a Senior USAID Official, Washington DC, April 19, 2012.

123 Author Interview with a Senior State Department Official, Washington DC, April 18, 2012.

124 Author Interview with a US Military Commander, Washington DC, April 29, 2012. 
bureaucratic sludge which is either unresponsive when something is wanted or bristling with bright ideas that no one needs'. ${ }^{125}$ True to his assertion, US officials and soldiers in the field considered factions within the US capital to be out of touch with the nation-building situation in Afghanistan. Due to their practical experience, they claimed to be more adept at understanding the complexities of nation-building, and were sceptical of the policies that emanated from the US capital. Both civilian and military officials were frustrated by the fact that the higher up the chain of command their ideas travelled the more ethereal they became. Washington's control over funding also resulted in unnecessary delays, and restricted the ability of actors in the field to act decisively. This hamstrung senior US officials who were attempting to direct and organize nation-building efforts. Gates, for example, claims that the gap between DC intelligence evaluations and 'the take of the guys in the field' left him feeling frustrated and confused. ${ }^{126}$

Dobbins considers his agenda to have been hampered by the Washington bureaucracy, which consisted of a fluctuating combination of the Pentagon, various civilian headquarters, Congress, the White House and the counter-bureaucracy:

I had organized what was regarded at the time as a model operation . . . [Washington] could not sustain the longer-term commitment that might have yielded more enduring results ... Washington had no plans for such engagements and, furthermore, it had not set aside any money to fund it. ${ }^{127}$

Similarly, a former US Ambassador could not comprehend why Washington consistently ignored suggestions from the US Embassy in Kabul. When questioned on the matter he was perplexed: 'It's not a question I have been able to answer completely to my own satisfaction', he says; 'why people [in Washington] couldn't understand is something I still don't know'. Neumann despaired of 'Washington's slowness to act on our predications of worsening security conditions' and argues that 'Washington's perceptions were stuck in an increasingly unrealistic appraisal of the situation'. ${ }^{128}$ Both he and Karl Eikenberry, the Commander of the Combined Forces, provided statements and reports to their colleagues in the US capital that stressed that they needed more resources and soldiers. Instead of granting that request, Washington did the opposite: it reduced US combat forces in the south from three to two battalions. ${ }^{129}$

Even officials with close ties to the Bush Administration, such as Zalmay Khalilzad, the US Ambassador to Afghanistan from 2003 to 2005, found it difficult to gain the necessary resources for effective nation-building. Similarly, influential military officials 'had great difficulty getting additional resources, which was

125 John Harr, The Professional Diplomat (Princeton: Princeton University Press, 1969), 302.

126 Gates, Duty, 210.

127 Dobbins, After the Taliban: Nation-Building in Afghanistan.

128 Author Interview with a Senior State Department Official, Washington DC, April 18, 2012.

129 Neumann The Other War: Winning and Losing Afghanistan. 
very frustrating and vexing'. One describes obtaining funding from Washington as 'rowing up the river against the tide, because the institutions and bureaucracies were trying to get other things done or trying to fight their turf battles'. ${ }^{130}$

Alternatively, the Washington bureaucracy was aggravated by the fact that the day-to-day implementation of nation-building activities in Afghanistan was a far cry from what it desired. Washington saw itself as a source of instruction and guidance and questioned the validity of decisions undertaken by those in the field, who had a lesser place in each agency's formal hierarchy. Military commanders and civilian authority figures in Afghanistan were dispersed around the country, and maintaining effective communication channels in Afghanistan proved to be extremely difficult. As a result, agency headquarters in Washington received conflicting and confused proposals from the field. From the perspective of US officials in Washington, it would be against the interests of their agency to simply apply a rubber stamp to all of the suggestions that came from either Kabul, or the military headquarters at Bagram airbase. Moreover, as those operating in the field were removed from the policy-making process in Washington, they were ignorant of the numerous meetings that discussed how policy should be carried out in Afghanistan. Consequently, many complex and nuanced prerogatives that were developed to facilitate inter-agency cohesion, and produce overarching nationbuilding objectives, were unable to influence the distant hierarchies in the field. ${ }^{131}$

\section{Conclusion}

This chapter has provided evidence for both a lack of strong leadership on nationbuilding in Afghanistan, and bureaucratic incoherence driven by different agency interests, perceptions, culture and power. President Bush failed to address the bureaucratic problems associated with nation-building in Afghanistan. Although he was not the cause of intragovernmental divisions his actions, or lack of actions, exacerbated the problem.

The relative unity displayed during the invasion came as a consequence of the military establishment's dominance in its traditional area of expertise, warfighting. But that unity was not to last long. In the years after the Bonn Conference, there was a lack of agreement on the US's objective in Afghanistan, and the bureaucratic fracture lines widened. Each agency viewed Afghanistan's problems through the lenses of its own interests and entrenched culture, and hence pursued nation-building strategies that were frequently at odds with other agencies. Furthermore, each agency was endowed with unequal resources and capacities, which shaped differential power relations between them. This expressed itself in a range of problems, including ones driven by the military/civilian divide, the marginalization of USAID, the counter-bureaucracy's interference and the

130 Author Interview with a US Military Commander, Washington DC, April 29, 2012.

131 Author Interview with a Senior State Department Official, Washington DC April 21, 2012; Author Interview with a Senior Defence Department Official, Washington DC April 18, 2012. 
different views from Washington and those in the field. All of these intragovernmental problems combined to affect the way that the US foreign policy bureaucracy interpreted nation-building issues and approached nation-building ventures in Afghanistan, which was comparable to the blind man examining the elephant. Consequently, the 'whole-of-government' strategy so widely touted as being the solution to nation-building in Afghanistan eluded policy makers. This was clearly manifested around the issue of security, to which we now turn. 


\section{Security}

Afghanistan's tumultuous history has been characterized by conflict across a landscape dominated by tribal and ethnic rivalry. With this in mind, Lakhdar Brahimi, the United Nations Special Representative to Afghanistan from 2001 to 2004, stated that 'without genuine and lasting security in Afghanistan nothing will be possible, let alone the establishment of a new government'. ${ }^{1}$ William Maley, a seasoned observer of Afghani politics argues that restoration of a stable Afghan State depends 'heavily on a capacity to deliver security for the Afghan people'. In the aftermath of the 2001 invasion, therefore, an effective strategy for securing and then maintaining security was the first premise of all US nation-building efforts. The US foreign policy bureaucracy, however, was ill-prepared for the complex challenges that this entailed.

This chapter discusses how intragovernmental divisions impacted on US efforts to establish a secure environment for nation-building in Afghanistan. First, it examines US attitudes towards and relationships with the International Security and Assistance Force (ISAF). Second, it evaluates the US military's training programme for the Afghan National Army (ANA). Third, it reveals the disorderly approach that the State Department and the military establishment took toward the enterprise of training the Afghan National Police (ANP). Finally, the chapter examines the CIA's role in supporting Afghanistan's warlords and the impact that this had on security and the US nation-building programme.

\section{The International Security Assistance Force}

Numerous studies have found that a substantial commitment to achieving countrywide security is required within the first 6-12 months after external intervention,

1 Lakhdar Brahimi, Briefing to the Security Council, United Nations, 13 November 2001, http:// www.un.org/News/dh/latest/afghan/brahimi-sc-briefing.htm (accessed 13/07/2011).

2 William Maley, Stabilizing Afghanistan: Threats and Challenges, Carnegie Endowment for International Peace, October 2008; William Maley, Rescuing Afghanistan (Sydney: UNSW Press, 2006), 57; and Richard Rupp, "High Hopes and Limited Prospects: Washington's Security and NationBuilding Aims in Afghanistan”, Cambridge Review of International Affairs, 19:2 (2006), 286-296. 
if nation-building is to be effective. ${ }^{3}$ With this in mind, the formation of the International Security Assistance Force (ISAF) was announced in December 2001, at the conclusion of the Bonn Conference, as an umbrella organization to incorporate military personnel from multiple countries.

Inside Kabul the ISAF performed admirably and it has been commended as an effective security force. ${ }^{4}$ But the stability of Afghanistan's capital was distinguishable from the violence that inundated the remainder of the country. In 2002, President Karzai revealed that 'Afghans from the country's most remote corners had come to him asking for peacekeepers'. ${ }^{5}$ Most of the non-US NATO countries were determined to give the ISAF a nationwide mandate so that it could provide a comprehensive security blanket for Afghanistan. This never came about, largely because of resistance from the US military and the White House. Although General John McColl, the first ISAF commander, exhorted the US to allow his forces to have a country-wide mandate, his and other appeals were rejected by the Bush Administration. ${ }^{6}$ Initially, the ISAF was only authorized to conduct small-scale operations outside of Kabul in areas that were controlled by the Northern Alliance, such as the north-east province of Kundunz. In its first four years, the ISAF gained no broader mandate than this. As a consequence, it was widely considered to be an ineffective force, its deliberate neutering derided as 'a blunder of horrendous proportions'?

The blame for the ISAF's ineffectiveness has often, and with good reason, been levelled at the United States. The European Union Special Representative to Afghanistan, Francesco Vendrel, argued that the US decision to restrict the expansion and jurisdiction of the ISAF 'limited its effectiveness'. ${ }^{8}$ Maley is more emphatic. He said of its corralling that 'there could have been no move more calculated to undermine the positive momentum of Afghanistan's transition'. ${ }^{9}$ Additionally, because the ISAF was not sufficiently supported by the US military there were severe equipment shortages. In December 2003, for example, the ISAF air presence consisted of only a few transport helicopters. Troop numbers increased at a snail's pace, with just over 6,000 operating by April 2004, which amounted to one ISAF soldier for every 5,000 Afghans. Due to the inconsequentiality of ISAF, the balance of power shifted to tribal leaders, warlords and the Taliban: 'If you're

3 Albert Somit and Steven Peterson, The Failure of Democratic Nation Building: Ideology Meets Evolution (New York: Palgrave Macmillan, 2005); Anthony Cordesman, The War after the War: Strategic Lessons of Iraq and Afghanistan (Santa Monica: RAND Corporation, 2003); Simon Chesterman You, The People; The United Nations, Transitional Administration and State-Building (New York: Oxford University Press, 2004).

4 Barnett Rubin, Afghanistan's Uncertain Transition From Turmoil to Normalcy, Council on Foreign Relations, Brookings Institute, 2006, 6.

5 Amy Waldman, “Afghan Leader Warily Backs US Bombing”, New York Times, January 2, 2002.

6 Rashid, Descent into Chaos, 132.

7 Maley, The Afghanistan Wars, 236.

8 Seth Jones, In the Graveyard of Empires (New York: W. W. Norton \& Company, 2010), 133.

9 Maley, The Afghanistan Wars, 236. 
going to call these troops security forces ... then put "security" in quotes and tell us what specifically you mean by it', one senior UN official bitterly quipped. ${ }^{10}$

Despite generalized US antipathy, or at least indifference, to the ISAF, the US bureaucracy was not united in its approach. The military establishment and State Department had contrasting perceptions of the ISAF's value and significance. Although there were occasionally supportive statements from senior military officials, the US military establishment largely viewed the ISAF as a distraction from its war-fighting role in Afghanistan. The DoD was especially uninterested in committing US troops to what it considered to be a vague security mandate in Afghanistan. For the Pentagon, a US troop presence under the auspices of the ISAF smacked of UN-style peacekeeping. US military culture typically dismisses such activities as fanciful and beyond the scope of the soldier's vocation, thus encouraging military commanders and DoD officials to avoid them. Indeed, the name 'ISAF' was an outcome of the military establishment's opposition to anything that even remotely resembled a peacekeeping force. In addition to this cultural aversion to 'peacekeeping', and a lack of interest in issues that sat outside the GWOT, was Donald Rumsfeld's perception that Afghanistan had, by 2003, switched to a 'stabilization operation mode'. Rumsfeld assumed 'the bulk of the country today is permissive, it's secure', and this interpretation subsequently pervaded the Pentagon and the White House. ${ }^{11}$

Alternatively, the State Department's interest in diplomacy predisposed it to take the opinions of NATO countries more seriously, and to view the ISAF as an essential component of the nation-building mission in Afghanistan. There was no cultural aversion to a US commitment to an international force that was based around peacekeeping ideals. In a number of inter-agency meetings throughout 2002, therefore, the State Department proposed that the US commit soldiers to the ISAF. ${ }^{12}$ The military establishment opposed this position. This resulted in the two factions attempting to steer the US government towards an acceptance of their own position. The battle lines were drawn between senior State Department officials - who were of the opinion that the ISAF could stabilize key urban areas in Afghanistan and military officials, 'who vehemently opposed any pretense of nation-building. ${ }^{13}$

The Departmental Secretaries engaged in a protracted debate. Colin Powell expressed his wish for the US to take 'charge of the whole country by military force, police or other means', while Donald Rumsfeld trenchantly opposed the commitment to the ISAF. ${ }^{14}$ Rumsfeld ostensibly premised his opposition to the ISAF on the historical animosity Afghans held toward foreigners. More

10 Carl Robichaud "Remember Afghanistan? A Glass Half Full, On the Titanic", World Policy Journal, Spring (2008), 19.

11 Rashid, Descent into Chaos, 200.

12 Michael Gordon, "US Backs Increase in Peacekeepers for Afghanistan", New York Times, August 30, 2002.

13 Jones, In the Graveyard of Empires, 109, 112-113.

14 David Rohde and David Sanger, "How a 'Good War' in Afghanistan Went Bad", New York Times, August 12, 2007, 2. 
realistically, he was determined to block Powell's proposal because of the impact it would have had on the military's unilateral mobilization for the invasion of Iraq, an endeavour that further strengthened the Defence Secretary's apathetic attitude toward NATO. Not content with abandoning the ISAF, the military also campaigned to restrict its operational capacity. Despite the urgings of Powell, Richard Haas and the US Special Envoy to Afghanistan, James Dobbins, the Pentagon refused to condone the expansion of the ISAF. ${ }^{15}$ Meanwhile, Senator Joe Biden, amongst other members of Congress, questioned the resistance from the military wing of US government to 'any expansion of ISAF when everyone has called for an expansion'. ${ }^{16}$ His question largely fell on deaf ears within the DoD.

We can see, then, that US policy toward the ISAF was riven with tensions and contradiction. But most critics had no influence within the corridors of the Pentagon, whose interests were given precedence by the White House. Helped by Rumsfeld's close relationship with powerful figures such as Dick Cheney, the military gained the support of President Bush. This ensured that the US would not commit a single soldier to the ISAF until it was rebranded in 2006 to incorporate US troops.

\section{US Efforts to Train the Afghan National Army}

In place of the ISAF, developing the Afghan National Army (ANA) was the centrepiece of the US commitment to Afghanistan's security. From 2002 to 2010, the US spent approximately $\$ 29$ billion, developing Afghanistan's security forces. ${ }^{17}$ The White House claimed that this was the most feasible path to stability: 'Better yet than peacekeepers . . . let's have Afghanistan have her own military', President Bush said. ${ }^{18} \mathrm{He}$ asserted that 'peace will be achieved by helping Afghanistan train and develop its own national army'. ${ }^{19}$ Like the US President, the military establishment argued that the ANA was a silver bullet for Afghanistan's security problems. General Tommy Franks claimed that it would 'permit a free country to evolve and prosper' ${ }^{20}$ Some elements of the US military were comfortable with US assistance to establish the ANA, which fell within their traditional area of expertise. For example, the support of foreign militaries is a role that the United

15 Michael Gordon, "Policy Divisions: CIA sees Threat, Afghan Factions May Bring Chaos", New York Times, February 21, 2002, http:/www.nytimes.com/2002/02/21/world/nation-challengedpolicy-divisions-cia-sees-threat-afghan-factions-may-bring.html (20/9/2012).

16 Rashid, Descent into Chaos, 134.

17 Special Inspector General for Afghanistan, Quarterly Report to the United States Congress, January $30,2011,32$.

18 Todd Purdum, "Bush Offers Afghanistan US Help for Training of Military and Police", New York Times, January 29, 2002.

19 James Dao, "Bush Sets Role for US in Afghan Rebuilding", New York Times, April 18, 2002.

20 Tommy Franks, American Soldier (New York: Harper Collins, 2004), 549. 
States Marine Corps has performed in the past, most prolifically in Central and South America. ${ }^{21}$

In the first few years of nation-building, all other issues were secondary to the training and equipping of Afghanistan's army. But its development did not progress smoothly. The US officially began to cultivate the ANA in April 2002. Due to bureaucratic delays, however, its plans would not begin to be implemented until June 2002, over 6 months after the fall of the Taliban. From the outset, desertion rates were a significant problem, and had reached 10 per cent by mid-2003. Criminality was common in most ANA units, and because its recruits were mainly former guerrilla fighters, they had no formal military experience. ${ }^{22}$ Moreover, diverse ethnic and tribal loyalties made the creation of a cohesive national fighting force all that more difficult.

Yet the ANA's initial problems cannot be blamed solely on the calibre of its recruits. Despite accepting responsibility to train the ANA, the US military was still more interested in and committed to combat operations in Afghanistan. This meant that the ANA lacked resources. There was not enough equipment for it to function properly - in terms of weapons, vehicles and communications infrastructure. ANA recruits were also paid an extremely low wage, which was insufficient to adequately support a family. Approximately $\$ 290$ million a year was pledged by the State Department for the ANA programme at the Bonn Conference, but this was far short of what was required. Astonishingly, reluctance from the Pentagon and other bureaucratic forces to commit US resources in Afghanistan reduced this number to $\$ 70$ million in 2002 and $\$ 151$ million in 2003. This occurred regardless of lobbying from State Department Officials, one of which described the level of funding for the ANA from 2001 to 2004 as 'grossly inadequate'. ${ }^{23}$

General Craig Western, the US commander in charge of the ANA programme, supported Taylor's assessment. Western constantly informed his superiors that he required more resources to properly train and equip Afghanistan's army, but his requests fell on deaf ears. ${ }^{24}$ Some US trainers claimed that a lack of funds was due to a lack of interest from policy makers in Washington, who at that time were preoccupied with events in Iraq. ${ }^{25}$ The Pentagon was unmoved by these assessments. As a consequence, in stark comparison to the multitudes of Afghan militia forces roaming the country, in 2004 the ANA consisted of only 9,000 soldiers, a

21 William LeoGrande, Our Own Backyard: The United States in Central America, 1977-1992 (Chapel Hill: University of North Carolina Press, 1998).

22 Maley, Rescuing Afghanistan, 72; Gilles Dorronsoro, Revolution Unending: Afghanistan 1979 to the Present (New York: Columbia University Press, 2005), 338.

23 Author Interview with a Senior State Department Official, Washington DC, April 21, 2012.

24 Anthony Cordesman,. The Ongoing Lessons of Afghanistan: Warfighting, Intelligence, Force Transformation, and Nation Building (Washington DC: Center for Strategic and International studies, 2005), 140.

25 Benjamin Tupper, Greetings from Afghanistan: Send More Ammo (New York: Penguin, 2011), $17-88$. 
number 'grossly inadequate to provide the Afghan government with a meaningful security capability' ${ }^{26}$

In 2005, the Taliban-led insurgency intensified and began to violently contest the US occupation. In this context, the Pentagon's interest in the ANA transformed from rhetoric to substance. Increased media exposure of Afghanistan's tribulations led Congress to pressure the military establishment to organize a more effective training programme for the ANA. The dire situation in Afghanistan also corresponded with a more stable political climate in Iraq, which gradually altered the Pentagon's perception as to which country was the primary battlefield in the War on Terror. Month after month the conflict in Afghanistan continued to intensify, and US military commanders in the field requested a drastic increase in US attention toward the ANA. Karl Eikenberry, the Commander of the Combined Forces from 2006 to 2007, and Major General Robert Durbin, the Security Transition Commander, asked Washington for more funds and equipment so that the ANA forces could fight alongside US soldiers against the Taliban-led insurgency. These factors combined to increase funding for the ANA to \$788 million in 2005 and $\$ 830$ million in 2006. ${ }^{27}$ By some estimates, between 2006 and 2008 the US military was able to secure $\$ 5.9$ billion to enhance Afghanistan's security forces.

With this increase in funding, and with a more comprehensive commitment from the US military, the ANA 'displayed a high degree of discipline, professionalism and combat effectiveness'. ${ }^{28}$ US trainers received clear orders from their superiors in Washington and this helped the military establishment to function as a cohesive unit. ${ }^{29}$ The Ethnic Integration Program helped ANA recruits to put country ahead of tribe or ethnicity, and close monitoring and mentoring by US forces served as a check against abuses within the force.$^{30}$ US trainers were 'committed and capable', and one of them described the ANA as 'firmly committed to fighting and destroying al-Qaeda and the Taliban'. ${ }^{31}$ A US Army colonel said that the ANA were 'fearless on the soldiering side' and quick to learn. ${ }^{32}$ As a result of US efforts, by the end of 2006 the ANA was operating in all regions of Afghanistan, and its soldiers took their place alongside coalition forces in areas where the Taliban were strongest, such as Kandahar Province.

26 Independent Task Force Cosponsored by the Council on Foreign Relations and the Asia Society, Are we Losing the Peace? (New York: Council on Foreign Relations, 2003), 11.

27 Jones, In the Graveyard of Empires, 171; Rashid, Descent into Chaos, 203.

28 Maley, Rescuing Afghanistan, 253.

29 Kenneth Katzman, "Afghanistan: Elections, Constitution and Government”, in Carey Gladstone, Afghanistan Issues: Security, Narcotics and Political Currents (New York: Nova Science Publishers, Inc., 2007), 54.

30 Cordesman, The Ongoing Lessons of Afghanistan, 139.

31 Jeff Courter, Afghan Journal: A Soldier's Year in Afghanistan (Illinois: Independent Publishing Platform, 2008), 68; Tupper, Greetings from Afghanistan: Send More Ammo, 18.

32 Eric Schmitt, "Where Armies Must be Built, it's Slow (Iraq) and Even Slower (Afghanistan)", New York Times, September 25, 2005. 
Robert Gates, Rumsfeld's successor, considered the US training programme to have produced 'tangible results'. Rather than linking the ANA to US nationbuilding, Gates described it as the lynchpin of the US military's counter-insurgency drive. ${ }^{33}$ Other observers, meanwhile, praised the ANA as an effective multi-ethnic institution that was 'the most successful US-led nation-building exercise in Afghanistan'. ${ }^{34}$ When questioned as to why the ANA programme proved to be effective, at least when compared to other US nation-building projects, a Senior Military Commander stated that 'you had a pretty powerful animal in the zoo called the US military behind that particular problem set'. ${ }^{35}$ The relative absence of bureaucratic hurdles to the ANA's development after 2005/6 is a testament to the power of the military establishment when it commits to a task that sits inside its traditional area of expertise.

\section{US Efforts to Train the Afghan National Police}

A credible police force provides public security and reinforces the legitimacy of the state. ${ }^{36}$ But establishing a police force in a conflict-ridden environment, such as Afghanistan, was a steep challenge. Initially, Germany was responsible for the development of the Afghan National Police (ANP), but they committed little money and few trainers, and had only managed to create a force of approximately 3,000 officers by the end of 2003. This number did not come close to the 50,000 officers, plus 12,000 border police, proposed at the Bonn Conference. The US believed it could improve on the German effort and commandeered the ANP programme in 2004. Thereafter, billions of dollars were committed by the US to train and equip Afghanistan's police force. Unlike the ISAF and the ANA, where US policy had been dominated by the military establishment, the ANP programme was subjected to a confusing division of responsibilities. Relevant parties included the Defence Department, the US Army, the US embassy, the Bureau of International Narcotics and Law Enforcement Affairs, and State Department contractors. ${ }^{37}$

There were many problems with the way in which the ANP evolved. Firstly, the phenomenon of 'conveyer belt' training tarnished the US programme. When judged on numbers alone, ANP growth seemed impressive. At the beginning of

33 Thom Shanker, "Top Officials Greet Gates in Kabul with Pleas", New York Times, December 5, 2007.

34 Rashid, Descent into Chaos, 413. Crisis Group Asia, “Countering Afghanistan's Insurgency: No Quick Fixes, Report No123”, November 2, 2006, 16; Seth Jones and Christine Fair, "Securing Afghanistan, Getting on Track", United States Institute of Peace Working Paper, January 23, 2009, 10.

35 Author Interview with a Senior US Military Commander, Washington DC, April 29, 2012.

36 Robert Reiner, The Politics of the Police (Oxford: Oxford University Press, 2010).

37 Charles Johnson, "Reforming Afghanistan's National Police", Testimony Before the Subcommittee on National Security and Foreign Affairs, June 18, 2008, http://www.gao.gov/assets/130/120423. html (accessed 3/5/2012). 
2007 , the US claimed it had an operational capacity of over 65,000 and by the end of Bush's second term its numbers approached 80,000. But these figures were misleading. Many officers on the ANP payroll had deserted and some simply did not exist. Those who did desert kept the weapons that they had been given. Those weapons strengthened tribal militias and often found their way to the Taliban. ${ }^{38}$

Notwithstanding the numbers on paper, there were substantial police shortages in most of Afghanistan's provinces. In 2006, a Kandahar governor counted only 35 to 60 police in each of his districts. ${ }^{39}$ Moreover, since the US failed to provide additional trainers to correspond with the ANP's growth, the quality of the recruits was poor. A staggering 85 per cent of police officers were considered to have been 'incapable of basic police work'. ${ }^{40}$ The ANP also lacked provisions and less than half of its officers were adequately equipped. In a district in the Kandahar province, for example, only 20 guns were available for 110 policemen. ${ }^{41}$ Meanwhile, a police chief in the Ghazni Province had 'no rank, no money for food, and not enough clothing or gear to operate in cold weather'. ANP infrastructure in rural villages was often nonexistent. One police headquarters in the Baghlan Province consisted simply of a 'mud and stone building surrounded by a mud wall'. ${ }^{42}$

For a combination of reasons - including poor pay, inadequate training and poor quality recruits - the ANP became heavily involved in criminal enterprise across the country. Its officers participated in Afghanistan's drug trade and there were reports of prolific drug abuse within the force. Corruption descended down through the ranks, from captains to individual officers on the beat. Mirroring the tactics used by warlords during the 1990s, illegal checkpoints were constructed by the ANP on roads throughout the country in order to extort money from drivers. Local police stations were often either a law unto themselves or proxies for local powerbrokers. During national and local elections, the police manipulated the political process through intimidation and vote rigging. Consequently, much of the Afghan populace considered the ANP to represent the interests of local strongmen, criminals and gangs, rather than those of the Afghan State. ${ }^{43}$

38 Royal United Services Institute for Defence and Security Studies and the Foreign Policy Research Institute Reforming Afghanistan's National Police, Royal United Services Institute for Defence and Security Studies (London) and the Foreign Policy Research Institute (Philadelphia), Joint Report, November, 2009, 88.

39 Crisis Group Asia, Countering Afghanistan's Insurgency, No Quick Fixes, 16

40 Michael E. O'Hanlon and Sherjan Hassina, Toughing it out in Afghanistan (Washington DC: Brookings Institution, 2010), 28.

41 Carlotta Gall, "Panel Faults US Trained Afghan Police", New York Times, December 4, 2006.

42 Atiq Sarwari and Robert Crews, "Afghanistan and the Pax Americana", in Robert Crews and Amin Tarzi (eds), The Taliban and the Crisis of Afghanistan (New York: Harvard University Press, 2008), 326; Nick Turse, "The 700 Military Bases: Black Sites in the Empire of Bases", in Nick Turse (ed.), The Case for Withdrawal from Afghanistan (London: Verso, 2010), 135-140.

43 C.J. Chivers, "Afghan Police Struggle to Work a Beat in a War", New York Times, January 13, 2008; C.J. Chivers, “As Funding Increases, Afghan Forces Range From Ragtag to Ready”, New York Times, May 2, 2007; Chris Johnson and Leslie Jolyom, Afghanistan: The Mirage of Peace (London: Zed Books, 2008), 134; Vance Serchuk, Cop Out: Why Afghanistan Has No Police 
The ANP resembled little more than disorganized militias lacking the capacity to enforce the law, let alone engage in counter-insurgency. Nonetheless, it was propelled into the frontline. In 2007, the ANP suffered more than 1,000 insurgency-related deaths, more than the ANA and NATO combined. When US soldiers moved on from a given area, the ANP remained and became the target of Taliban retaliation. For example, after US troops withdrew from the Panjwayi and Zhari districts in Kandahar, the Taliban assaulted police outposts in bloody retribution. Placing the ANP in such scenarios exacerbated the problem of desertion. A senior US military official observed that high casualties resulted in the ANP 'bleeding personnel'. ${ }^{44}$

Responsibility for the ANP training programme was divided and dispersed. In 2005, primary authority transferred from the State Department to the military establishment. The transition was not streamlined, nor was it complete. The Pentagon was charged with the execution of the US training programme, but the State Department still retained contract management authority for police training. Theoretically, the State Department also provided policy guidance to assist the military. The State Department staffed the 'Central Training Center' in Kabul as well as a number of Regional Training Centers. Meanwhile, the Defence Department's Task Force Police Directorate and Police Reform Directorate had a separate mandate, which was 'training, mentoring and organizing the ANP to enable them to perform the full spectrum of traditional law enforcement roles'. ${ }^{45}$

For nine months during 2005 to 2006, General Barno attempted to convince the White House of the need for the military to collaborate with its civilian counterparts, but without success. ${ }^{46}$ There was no-one from the DoD who had any technical knowledge of the contracts that it had inherited from the State Department. This caused a great deal of confusion as to its details and thus how to move forward. Furthermore, military reports detailing plans to reform the ANP training programme did 'not identify or discuss the roles and responsibilities of State'. ${ }^{47}$ The State Department did not contribute to those reports, but at the same time failed to develop any plans of its own. A joint report between the two agencies called for more collaboration to enhance the US training mission, but made no mention of how this would be achieved. ${ }^{48}$ Consequently, the only line connecting the State Department's training centres to the military's programme was a single

(American Enterprise Institute for Public Policy Research, 2006), 2; Human Rights Watch, Afghanistan: Return of the Warlords, Human Rights Watch Briefing Paper, 2002, 6 and 14; Brian G. Williams, Afghanistan Declassified: A Guide to America's Longest War (Philadelphia: University of Pennsylvania Press, 2012), 199.

44 Crisis Group Asia, Countering Afghanistan's Insurgency, No Quick Fixes, 14.

45 Inspectors General, US Department of State and US Department of Defence, Interagency Assessment of Afghanistan Police Training and Readiness, November 2006, 17.

46 Author Interview with David Barno.

47 Johnson, "Reforming Afghanistan's National Police", 14.

48 Rohde, "Panel Faults US-Trained Afghan Police". 
'embedded senior staff officer'. ${ }^{49}$ This caused numerous bureaucratic delays. Ambassador Neumann cited one example where:

An effort to transfer a measly $\$ 200$ million from army to police equipment encountered six months of bureaucratic delay in the middle levels of the Pentagon and was finally broken loose only when I called the deputy Secretary of Defence, Gordon England, who resolved the internal problem within twentyfour hours. I mentally kicked myself for not having called him earlier. ${ }^{50}$

A Senior State Department Official explained how cultural differences exacerbated and complicated these and other problems:

There were bureaucratic struggles between, on the one hand, the military, which worried about the police surviving attacks, and, on the other hand, State civilians concerned that the civilian police force would become militarized, which lasted months. There was some virtue on each side and none in their refusal to reach agreement. ${ }^{51}$

The ANP functioned as the vanguard in the fight against the Taliban because the military establishment considered it to be a key weapon in its counterinsurgency arsenal. This may explain why it was classified under the broad banner of the Afghan National Security Forces, alongside the ANA. The Department of Defence claimed its programme was 'the critical lynchpin to the efforts to build and sustain a viable and resourced national police force', although it trained the ANP as an auxiliary force to support Afghanistan's army. ${ }^{52}$ During a congressional hearing in 2007, Eikenberry categorized the ANA and ANP as one and the same and spoke of progress with each synonymously. Similarly, Barno asserted that the ANP formed 'the front line of Defence in this war', a description he also applied to the ANA. ${ }^{53}$ The US military, therefore, embraced the ANP programme, but only as far as it suited its interest in typecasting Afghanistan's security forces as a bulwark against the insurgency. A Senior State Department Official argued that this meant that the military 'didn't approach the ANP in Afghanistan as a train

49 Inspectors General, US Department of State and US Department of Defence, Interagency Assessment of Afghanistan Police Training and Readiness, 8.

50 Ronald Neumann, The Other War: Winning and Losing Afghanistan (Washington DC: Potomac Books, Kindle Addition, 2009).

51 Author Interview with a Senior State Department Official, Washington DC, April 18, 2012.

52 Department of Defence, Report on Progress toward Security and Stability in Afghanistan, June 2008, 27.

53 Committee on Armed Services, Assessment of Security and Stability in Afghanistan and Development in US Strategy and Operations, House of Representatives, One Hundred Tenth Congressional Hearing, February 13, 2007, 22; Committee on Armed Services, Assessment of US Strategy and Operations in Afghanistan and the Way Ahead, House Of Representatives, One Hundred Tenth Congress, Second Session Hearing, January 23, 2008, 32. 
and equip program; they approached it as a take apart from nothing and rebuild it program'. ${ }^{54}$

The military's interests were displayed when in late 2006 problems in southern Afghanistan resulted in the extraction and relocation of US military trainers from the north to perform the duty of 'mentor saturation teams'. The US military modified its training regime for the ANP in direct response to insurgent attacks. An appraisal of this strategy by the Office of the Inspector General was critical of the fact that 'this action left a mentor gap in the northern provinces', and that the military declined to produce a 'timetable for replacing these mentors in the north' ${ }^{55}$

Similarly, the Afghan National Civil Order Police (ANCOP) had been created, according to a US Deputy Commander for Police Development, to fight against the 'enemies of peace and stability'. Yet it had also been fashioned as another instrument for its counter-insurgency strategy. ANCOP was supposedly designed to respond to civil unrest, but it functioned as an elite mobile military force in dangerous or conflict-ridden provinces, where the Taliban presence was strongest. This mirrored the Pentagon's training regime for the ANA, and discounted a broader nation-building mandate. ANCOP's actions in Marja, for example, reflected the US military's interest in sculpting the force into an elite combat unit. $^{56}$

Another example was the Focused District Development (FDD) programme, which the Department of Defence modified in October 2007. Previously, the State Department had classified eight policing regions to reflect Afghanistan's patchwork of ethnic factions. However, the military warped the FDD so that the eight regions were reduced to five, without cause or explanation. Districts were selected on the basis of which of them the DoD perceived to be in need of most help, regardless of whether they actually required police reform and retraining. Reorganizing the FDD programme so that they accounted for tribal and ethnic boundaries was aimed at complementing the US military's command structure. A report from the Defence Department conceded that within the first seven cycles of FDD 'there were no formalized procedures for collaboration to select which districts would go through the FDD program'.${ }^{57}$ A shortage of personnel also constrained plans to expand FDD to the rest of Afghanistan. These problems may have been avoided had the Pentagon communicated with its colleagues at the State Department, but there was only one, or sometimes no, civilian trainers operating within FDD teams.

54 Author Interview with a Senior State Department Official, Washington DC, April 18, 2012.

55 Inspectors General, US Department of State and US Department of Defence, Interagency Assessment of Afghanistan Police Training and Readiness, 24.

56 Paul Dillard, “ANCOP Graduates 321 New Officers”, Blackanthem Military News, July 1, 2009, http://www.blackanthem.com/News/afghanistan/ANCOP-Graduates-321-New-Officers20328. shtml (accessed 30/11/2012); C.J Chivers, 'Afghan Police Earn Poor Grade for Marja Mission', New York Times, June 1, 2010, http:/www.nytimes.com/2010/06/02/world/asia/02marja.html? $\mathrm{r}=2$ (accessed 30/11/2012).

57 Department of Defence, Report on Progress toward Security and Stability in Afghanistan, 37. 
The military's fixation on counter-insurgency also produced the Afghan Auxiliary Police (AAP), which was created in September 2006. A niche DoD initiative, the AAP empowered a patchwork of Afghan militia to perform police duties in place of an ANP presence. Assortments of tribal footmen were hurried through a ten-day training programme. By this baptism of fire its numbers quickly grew to over 10,000. In essence, the DoD had sutured together a supplementary Afghan force based on the idea that it could replace not just ANP officers, but also US troops. All it in fact accomplished was the armament of men whose loyalty was to their tribes rather than to the national government. Unlike the ANCOP, the AAP generated cleavages within the military establishment due to different perspectives as to its worth. The main difference was between DoD officials in Washington and military commanders in the field. Eikenberry, for example, did not believe the AAP to be helpful in the military's quest to construct an effective counter-insurgency platform. He argued that it was merely a 'stopgap measure' and an inappropriate 'tactical' solution to a 'systemic' problem. ${ }^{58}$ Outside of the military establishment, meanwhile, the AAP was considered to be an ineffective and illegitimate force, which had added to Afghanistan's insecurity instead of helping to cure it. ${ }^{59}$ The programme was terminated in September 2008, after the Pentagon finally recognized its failings.

Although there was broad acceptance that the ANP should be involved in the counter-insurgency effort, divisions between Washington and military officials in the field emerged. In 2007, General Barry McCaffrey, a US Army general in Afghanistan, wrote a memo to the Military Academy at West Point, which said that the effort to create the police was 'grossly under-resourced' and that this needed to be addressed immediately. McCaffrey's request was ignored, as was Major General Robert Crone's 2008 request for 2,300 more ANP trainers. ${ }^{60}$

As soldiers in the field experienced the deficiencies of the ANP firsthand, they were much more critical of the US training programme than their colleagues in Washington. Barno despaired of the methods that were being used to train the police: 'You give them a badge, a night stick and a certificate and then send them back to the cesspool that was their original police station', he bitterly remarked. Major General John T. Brennan described the ANP as 'a hollow force'. ${ }^{61}$ Colonel Rick Adams, head of the Police Reform Directorate for the US-led Combined Security Command, made it clear to his superiors at the Pentagon that rather than prepare the ANP for counter-insurgency the US first needed to overcome 'a culture of corruption'. After his translator was brutally beaten, a Special Forces

58 Jones, In the Graveyard of Empires, 176.

59 Royal United Services Institute for Defence and Security Studies and the Foreign Policy Research Institute, Reforming Afghanistan's National Police, 88.

60 James Rupert, "US Loses Ground as Afghanistan Erodes", The Seattle Times, September 20, 2007; Department of Defence, "News Briefing with Major General Cone from Afghanistan", November 12, 2008. http://www.Defence.gov/transcripts/transcript.aspx?transcriptid=4314 (accessed 16/04/2013).

61 Schmitt, "Where Armies Must Be Built, It's Slow (Iraq) and Even Slower (Afghanistan)". 
soldier stated that 'the ANP were known throughout Afghanistan for being corrupt, untrained thugs'. Another US trainer was shocked by the 'coercive tactics' the police used. ${ }^{62}$

US military trainers were also frustrated by the fact that counter-insurgency training and the size of the ANP were the Pentagon's only concerns. As US Army Captain Philip Poag admonished, 'you can't make some kind of human chain-link fence'. Another US trainer watched incredulously as inexperienced ANP recruits were drilled on how to respond to a full-scale ambush at a training camp. Yet another stated that the ANP required 'more practice [and] more training'. He had observed that its frontline status compromised the professionalism and effectiveness of the US Army in Afghanistan. ${ }^{63}$

These frustrations were compounded by US trainers not being given adequate briefing prior to deployment. Soldiers appointed to train the ANP entered Afghanistan unaware of how to do their job. This was partially because the construction of a police force was alien to military culture. As a Senior Military Official states:

Whereas the military problem set was relatively straightforward for us, the civilian police problem set goes down to every village and involves the entire fabric of society; the legal system; the penal system; the challenges in criminality and so on.... That is a much more complex, ugly, difficult animal that we have experience with. ${ }^{64}$

Captain Daniel Helmer, a former ANP trainer in Afghanistan, asserts that the generic training programme for US trainers made no distinction between soldiers who were deployed to Afghanistan and those deployed to Iraq. He considered this to be extremely problematic as it failed to adequately prepare them for the situation on the ground. A trainer with the Afghan Border Police (ABP) recounted the same experience as Helmer: 'We did not know what we were getting into - we had no defined training objectives, no training materials and no formally defined objective', he states. He and his colleagues approached the task with a willing tenacity, but he admitted that it was a duty they were unqualified to perform. ${ }^{65}$

Unlike the US military, the State Department viewed the ANP as complementing a broader nation-building strategy, which positioned security and law and order as important considerations. But it failed to take responsibility for the ANP's development, and its approach was characterized by disinterest and disorganization, as the following example illustrates.

62 Jones, In the Graveyard of Empires, 172; Rusty Bradley, Lions of Kandahar (New York: Random House, 2011), 45; Courter, Afghan Journal, 95.

63 Laura King, "Change on Afghan Border", Los Angeles Times, July 2, 2009; Jones, In the Graveyard of Empires, 176; Courter, Afghan Journal, 261, 75 and 261.

64 Author Interview with a US Military Commander, Washington DC, April 29, 2012.

65 Crisis Group Asia, Reforming Afghanistan's Police, 91. Courter, Afghan Journal, 356. 
The Bureau of International Narcotics and Law Enforcement Affairs (INL) directed the State Department's ANP programme. The INL seemed to be the most logical choice due to its historic support for criminal justice systems abroad. Upon closer examination, however, the bureau's culture prepares its agents to combat international drug cartels, rather than to create and organize a nationwide police force on a foreign shore. In addition, training the ANP did not fit within the paradigm of INL's interests in Afghanistan, which centred on drug eradication and interdiction. ${ }^{66}$ Instead of spearheading the State Departments programme, therefore, the INL empowered private contractors. It briefed them on the vague goals of combating the insurgency and strengthening the Afghan State, but was indifferent to the contractors' lack of knowledge about Afghan culture and politics. The INL also divested itself of responsibility for how the trainers were chosen, which meant that many non-professionals joined the trainer ranks. Robert Perito, who led the International Criminal Investigative Training Assistance Program at the US Department of Justice, compared the situation in Afghanistan to previous nation-building scenarios:

The Department of Justice, where I headed the ICITAP program, trained police in Somalia and in Haiti and in Bosnia and in Kosovo, where you had full-time law enforcement professionals in charge of the training. But that model was abandoned when we got to Iraq and Afghanistan. Without anyone involved in the police training effort who is a law-enforcement professional, the leadership and the determination of what goes on in those projects then shifts to contractors. The contractors then are left to come up, based on their own devices, with what is to be done. ${ }^{67}$

DynCorp International (hereafter Dyncorp) was the company primarily responsible for the State Department's training programme. From 2004 to 2009 it received over $\$ 3$ billion in funds from the US government. ${ }^{68}$ Dyncorp's empowerment by the INL gave it an unfettered capability to decide how to approach the ANP's training. It created a Central Training Center for the police in Kabul, and a number of other facilities across the country. Dyncorp's training programmes usually involved no more than a short 2-8 week course for entry-level police. Although an intergovernmental assessment claimed that its trainers were 'a professional, dedicated, and enthusiastic group', the company's efforts were widely criticized. ${ }^{69}$ Jones asserts that Dyncorp's training programme produced 'a heavily

66 Department of State, Bureau for International Narcotics and Law Enforcement Affairs, International Narcotics Control Strategy Volume 1 Drug and Chemical Control, March 2010, http://www. state.gov/documents/organization/137411.pdf.

67 Commission on Wartime Contracting, An Urgent Need: Coordinating Reconstruction and Stabilization in Contingency Operations, 72.

68 Special Inspector General for Afghanistan, Quarterly Report to the United States Congress, United States Congress, January 30, 2011, 7.

69 Inspectors General, US Department of State and US Department of Defence, Interagency Assessment of Afghanistan Police Training and Readiness, 2 and 24. 
armed, undisciplined and thoroughly venal paramilitary force despised by Kabulis and feared by Afghan civilians in the countryside'.$^{70} \mathrm{~A}$ report conducted by Crisis Group Asia described the police offices that the company trained as "barely qualified mall guards'. ${ }^{71}$

Within the State Department there was also an awareness of the problematic nature of the company's training regime. Ambassador Neumann, for example, stated that 'what DynCorp did was take a police officer out of a cesspool, train him for a few weeks, and throw him back into a cesspool'. A State Department Official who was interviewed for this study agreed: 'If you are giving people two or three weeks' training to be a policeman you are not training them to be much of a policeman'. ${ }^{72}$ Yet similar observations from State Department officials in Kabul failed to influence its headquarters in Washington. This demonstrates that the agency's bureaucratic hierarchy prevents experienced officials in the field from rectifying poor policies.

The inability of Dyncorp and other contractors to adequately train the ANP generated conflict between the US military and the State Department. The military establishment considered the position of power that was given to private companies to be inappropriate. A Senior Defence Department Official asserts that the INL's empowerment of semi-autonomous actors compromised the interests of the military establishment:

The State Department's reliance on contractors caused a lot of friction. Strictly speaking, the responsibility (for the ANP) belonged to State, but State didn't have the personnel to do it. Very often the behavior of the contractors undermined the work of the military guys, because they were moving at cross-purposes. So you had incidents with contractors that destroyed six months' work on the part of a company or battalion commander, who was trying to develop a relationship with the local Afghans. ${ }^{73}$

A US General posted in Afghanistan was similarly critical in his analysis:

I think it was a matter of you put a contract on the street and measure success by how many individuals come out of the training pipeline, not whether you had an effective force. And so companies bid on that and I suspect the lowest bidder got the contract and a huge amount of money went to them, and the result was they produced people coming out the other end of the pipeline full stop. There was no effective police force connected to that. It was an

70 Jones, In the Graveyard of Empires, 176.

71 Crisis Group Asia, Crisis Group Asia Report 138, August 30, 2008.

72 Jones, In the Graveyard of Empires, 174; Author Interview with a Senior State Department Official, Washington DC, April 18, 2012.

73 Author Interview with a Senior Defence Department Official, Via Telephone, Sydney to Colorado, July 15, 2013. 
individual training program and not part of the fabric of a greater strategy toward the police. Fundamentally it was a failure. ${ }^{74}$

It is important to note how closely the perceptions of these two senior military officials align with that of Ambassador Neumann. Yet these and other like-minded individuals were never able to collaborate to overcome the problem of outsourcing. This is a testament to the entrenched barriers that each agency's interests, perception and culture presented to pursuing a logical and productive exchange of opinion that may have curtailed the State Department's reliance on contractors.

DynCorp, meanwhile, had a different opinion about who was to blame for the sorry state of its training programme. The company complained that there were unclear lines of authority within US bureaucracy, which stemmed from the fact that there were two autonomous programmes - one headed by the US military, the other by the State Department. According to Dyncorp, the different interests and culture of the two agencies led to complications in the deployment and placement of personnel, and the conduct of reform activities. Dyncorp's trainers, for example, were unable to travel unescorted to check police teams' equipment. Yet there was no move from the US military to provide escorts to rectify this problem. Moreover, the company argues that it received contradictory instructions from two different branches within the State Department: the INL and the Department of State's Bureau of Administration. INL's nominal authority notwithstanding, there was no point of contact to which DynCorp could turn for explanation and no consistent method for resolving contradictory instructions. ${ }^{75}$

As controversies surrounding the ANP bubbled to the surface in Washington, the counter-bureaucracy scrutinized the US training programme. From 2005, the GAO called for more effective methods of cooperation toward a united ANP training programme, but became frustrated when its advice was disregarded by the State Department and the military establishment. Subsequently, its investigations were increasingly critical of the both the military and civilian approach. In 2010, the GAO highlighted severe equipment shortages and poorly trained recruits, which resulted in no Afghan police unit being fully capable of performing its mission. ${ }^{76}$

74 Author Interview with a US Military Commander, Washington DC, April 29, 2012.

75 Charles Michael Johnson, Afghanistan Security: US Efforts to Develop Capable Afghan Police Force Face Challenges and Need a Coordinated Detailed Plan to Help Ensure Accountability, Testimony Before the Subcommittee on National Security and Foreign Affairs, Committee on Oversight and Government Reform, House of Representatives, United States Government Accountability Office, June 18, 2008, 14 and 94; Inspectors General, US Department of State and US Department of Defence, Interagency Assessment of Afghanistan Police Training and Readiness, 35.

76 Charles Johnson and Sharon Pickup, Afghanistan Security: Long-standing Challenges May Affect Progress and Sustainment of Afghan National Security Forces, Testimony Before the Subcommittee on Oversight and Investigations, Armed Services Committee, House of Representatives, United States Government Accountability Office, 2012, pp. 3-6. 
The Office of the Inspector General for Afghanistan (OIG), meanwhile, argued that there was little indication that military officials understood the distinct nature of policing. But like the GAO, the OIG perceived the main problem to be a lack of cohesion between the different training regimes. This, 'created a situation of the blind leading the blind', and prevented operational clarity: 'Neither CSTC-A [the military command in Afghanistan], nor the INL office at the embassy has had a full understanding of contract commitments or requirements', an OIG report alleged. Both the advice and criticism of the GAO and OIG were ignored by US agencies and US contractors operating in Afghanistan. Although they were divided on everything else in respect of the ANP, the State Department and the Pentagon held a common interest in repelling the encroachment of Washington's regulatory bodies. Consequently, the findings of GAO and OIG reports were disputed by both. The State Department, for example, maintained that the ANP programme was 'well conceived and well executed'. ${ }^{77}$

Similarly, a 2008 report conducted by the DoD claimed that ANP recruits returned to their districts with 'enhanced capabilities and better able to serve their communities'. During a Congressional hearing in 2007, Karl Eikenberry defended the ANP as 'a good, comprehensive program'. ${ }^{78}$ At the urging of the GAO the military establishment did produce a plan for future improvements to its training programme. But that plan consisted of a five-page document that made no mention of the role and responsibilities of the State Department, nor did it provide a framework through which to pursue a joint policy platform. The State Department made no move to adhere to the edicts of the counter-bureaucracy beyond rhetorical platitudes.

Such intransigence notwithstanding, the counter-bureaucracy's obsession with statistics was not what was required to reform the ANP training programme. The GAO, OIJ and OMB added to the very problem it denounced, as increased oversight and reporting resulted in significant delays. The OMB especially, was eager to reject requests from US officials and commanders that may have improved the ANP, because they did not consider such requests to be fiscally responsible. In one instance, a State Department attempt to change one of its police training contractors was blocked by the contractor's protest to the GAO. Because contractors were officially, albeit controversially, part of the US bureaucracy, they were able to delay the process through these appeals. The Commission on Wartime Contracting, arguably another part of the counter-bureaucracy, discovered that 'the contractor won its challenge and set progress back six to nine months'. ${ }^{79}$

77 Inspectors General, US Department of State and US Department of Defence, Interagency Assessment of Afghanistan Police Training and Readiness, 14, 35 and 8.

78 Department of Defence, Report on Progress toward Security and Stability in Afghanistan, June, 2008; Committee on Armed Services, Assessment of Security and Stability in Afghanistan and Development in US, 18.

79 Anthony Cordesman. Afghan National Security Forces: What Will it Take to Implement the ISAF Strategy (Washington DC: Center for Strategic and International Studies, 2010), vi; Commission 
Inharmonious relations and competing agendas within the foreign policy bureaucracy help to explain why the ANP programme was a failure. One State Department staffer argues that the enterprise was flawed from the beginning: 'Blame should be leveled at the whole system and a lack of comprehension', he states. ${ }^{80}$ A US Military Commander believes that there was a lack of capacity within the US foreign policy bureaucracy to train another country's police force:

There is this huge gap in our federal government's capacity. We don't have a national police force. We don't have a ministry of the interior or a ministry of justice that does this kind of work. And we don't have a federal capacity to do prisons abroad. ${ }^{81}$

Without that capacity, each agency twisted the ANP programme to suit its interests. The quality of the training, meanwhile, was affected by each agency's culture. No conduits were developed to promote cooperation and the State Department and the military programmes remained entirely separate. The military establishment was not prepared to meet the challenge of creating a police force that could complement nation-building, especially when it was faced with a violent insurgency that it perceived to be a more immediate concern.

Dyncorp and other private contractors added another confusing layer of authority to the US programme to train the ANP. Its empowerment was a move that revealed a lack of knowledge and interest from the State Department in producing a suitable training programme. There was an absence of oversight from the INL, which did not have the capacity or any previous experience in overseeing a training program of such magnitude. The hierarchical and fragmented nature of the US bureaucracy also determined that US officials and commanders who perceived the ANP programme to be problematic, struggled to have their voices heard. The flawed nature of the US training programme precipitated interference from the counter-bureaucracy, which only exacerbated the situation.

\section{The CIA and Afghanistan's Warlords}

In addition to US efforts to build the ANA and ANP, the other important element in the overall security situation in Afghanistan was the role of the CIA in empowering various warlords. As discussed in previous chapters, during nation-building it is imperative that external agents carefully consider which domestic actors they will support. Such decisions were especially important in a post-Taliban environment, in order to distinguish Afghanistan's new political order from a violent past. But for the CIA this was not a concern. It selected and then maintained support for

on Wartime Contracting, An Urgent Need: Coordinating Reconstruction and Stabilization in Contingency Operations, 43.

80 Author Interview with a Senior State Department Official, Washington DC, April 18, 2012.

81 Author Interview with a US Military Commander, Washington DC, April 29, 2012. 
a number of Afghanistan's warlords, which compromised US efforts to establish a secure and stable Afghan State.

The CIA has been variously described as, 'a sovereign state within a state', and 'the invisible government'. The publicly-stated foreign policy of the United States takes one direction while the invisible government takes another. ${ }^{82}$ In Afghanistan, 'the invisible government' diverged from the rest of the foreign policy bureaucracy. The CIA interests revolved around finding remnants of Al Qaeda that lurked in the Tora Bora Mountains, tribal enclaves near the Durand Line, and other remote locations. In the lawless tribal belt, which functions as a de facto border between Afghanistan and Pakistan, Al Qaeda operatives were (and still are) able to move between the two countries like ghosts. From 2001 onwards the CIA's protracted battle against Al Qaeda in Afghanistan/Pakistan has been constant, albeit inconsistent.

Unlike military officials, who are accountable to strict hierarchies, CIA agents operate with far greater autonomy. In Afghanistan, neither the US Ambassador in Kabul, nor any senior US military commander in the field, had the power to control CIA operatives. Security, community relations and development were issues that did not impact on the CIA's decisions, even after the Taliban had re-emerged as a significant political force. The agency forged alliances with any Afghan leader that it believed could aid in the GWOT, regardless of how pernicious an impact this may have had on nation-building in Afghanistan.

To begin with, the CIA established a rapport with members of the Northern Alliance (NA). Formerly a stagnant force fighting a losing war against the Taliban, thanks to support from the CIA the NA had a tremendous reversal of fortune. In preparation for the invasion, Gary Schroen headed the first CIA team to enter Afghanistan. Code-named 'Jawbreaker', Schroen's and other CIA teams were given tens of millions of dollars in cash to distribute to warlords who operated within the NA framework, including such notorious figures as Abdul Rasul Sayyaf, Sayyed Jaffar, Abdul Karim Khalili, Ismal Khan and Rashid Dostum. ${ }^{83}$ This had a profound and immediate effect. Sayyed Jaffar, for example, had effectively no troops following his return to the country in 2001, but with CIA assistance he quickly obtained a force of over 1,000 soldiers. Through the provision of similar funds, the militia of Ismal Khan, which had been reduced to a few hundred in 2000, had risen to more than 5,000 men by 2002. By early 2002, the CIA had dispersed 767 tons of supplies (including hundreds of tons of ammunition) and $\$ 70$ million, which by some estimates was enough to equip and fund 50,000 militiamen. ${ }^{84}$ The CIA's interest in funding these individuals, and other tribal strongmen, continued unabated in the years that followed. This allowed those warlords

82 Andrew Bacevich, The Limits of Power: The End of American Exceptionalism, 5 and 90; David Wise and Thomas Ross, The Invisible Government (New York: Random House, 1964).

83 Gary Schroen, First in: An Insiders Account of How the CIA Spearheaded the War on Terror in Afghanistan (New York: Random House, 2005).

84 Dana Priest, The Mission: Waging War and Keeping Peace with America's Military (New York: W.W. Norton, 2003), 171. 
who had the backing of the CIA to forge powerful armies to challenge their rivals and control vast territories. One CIA operative asserts that the NA 'provided us with a native army to work with and an extremely valuable intelligence network to link into', 85

Alongside the warlords who were ensconced within the dubious framework of the Northern Alliance, the CIA established diplomatic ties with other local power brokers in Afghanistan's Central and Northern provinces. The agency also approached Pushtun leaders in the south. In each case, monetary bribes were used to win support for its efforts to locate Al Qaeda leaders. This contributed to the propagation of over 200,000 militiamen by the end of the first term of the Bush Administration. ${ }^{86}$

George Tenet, the CIA Director, plainly informed the White House that Afghanistan's 'pro-US' warlords were 'getting a lot of money'. 'Tenet wanted the gloves off, he was going to "rent" every warlord necessary in Afghanistan', Moens observes. ${ }^{87}$ But these overtures were more than just bribes. The CIA pursued a myopic yet resolute strategy to shape the political future of Afghanistan. In order to satisfy his agency's interests, Tenet perceived that it was necessary to modify Afghanistan's political geography:

We had a counterterrorism strategy, now we need a political strategy. We need to tell the southern tribes what the political scenario is. We need the vision. We need to make it clear that we're there for the long term. ${ }^{88}$

This approach was what Ahmed Rashid called the 'warlord strategy', a term that encapsulates the CIA's strategy to portray Afghanistan's warlords as liberators and unifiers. ${ }^{89}$ If the target had strong democratic credentials he was considered to be more acceptable, but that was by no means a requirement.

Although the CIA operates outside the strict confines of foreign policy bureaucracy, it retains close ties with the military establishment. Rather than discouraging the CIA's warlord strategy, the Pentagon perceived it to be in its interests. A report conducted by the Council on Foreign Relations asserts that the US military 'excluded from their mandate either security enhancement or support for central government efforts to bring unruly warlords under its sway'. ${ }^{90}$ Instead, senior military officials visited regional despots such as Atta, Dostum, Shirazi,

85 Gary Berntsen and Ralph Pezzullo, Jawbreaker: The Attack on Bin Laden and Al-Qaeda (New York: Three Rivers Press, 2005), 313.

86 Antonio Giustozzi, Empires of Mud: War and Warlords in Afghanistan (London: Hurst \& Company, 2009).

87 Bob Woodward, Bush at War (New York: Simon \& Schuster, 2005), 192; Alexander Moens, The Foreign Policy of George W. Bush: Values, Strategy and Loyalty (London: Ashgate, 2003), 136.

88 Robert Draper, Dead Certain: The Presidency of George W. Bush (New York: Free Press, 2007), 226.

89 Rashid, Descent into Chaos, 132.

90 Independent Task Force, Are We Losing the Peace? (New York: Council on Foreign Relations, June 2003), 9. 
and Khan on multiple occasions, which helped consolidate each leader's power. Through CIA brokerage, the Pentagon recognized the warlords' militias as proUS ground forces that substituted for US soldiers and an ANA/ANP presence. Rumsfeld described Afghanistan's warlords as an integral part of the country's security apparatus:

How ought security to evolve in that country depends on really two things; one is what the interim government decides they think ought to happen, [the other is] what the warlord forces in the country decide they think ought to happen, and the interaction between those two. ${ }^{91}$

The Pentagon also assisted CIA agents in their efforts to fashion alliances based on a choice between the United States and Al Qaeda. Tenet recalls that when his operatives questioned tribal leaders on whether or not they would support the US, 'if the answer was yes, goods, medical supplies, military equipment, and weapons would soon be air dropped to them'. But if the answer was no, they would receive 'a two-thousand-pound bomb courtesy of the US Military'. ${ }^{92}$

While senior officials at the Pentagon accepted the warlord strategy, many military officials in the field did not. Zakheim argues that some warlords were a stabilizing presence while others undermined security, but the CIA did not attempt to make a distinction between the two. ${ }^{93}$ In hindsight, he admits that the Pentagon's blanket acceptance of the CIA's strategy, especially in the first few years of the US occupation, was problematic. But although the military establishment expressed less enthusiasm for the CIA's tactics in Afghanistan during the second Bush Administration, this may have been due to its preoccupation with fighting a worsening insurgency, rather than a realization of how harmful the warlord strategy was to Afghanistan's security. ${ }^{94}$

Many US soldiers in the field, meanwhile, were against the warlord strategy from the beginning. They were frustrated by the fact that they could not cultivate a lasting relationship with Afghan villagers who blamed the US for the warlords' rapacious behaviour. A number of polls conducted by the US military confirmed this. One US Army Officer, for example, asserts that Afghanistan's warlords ruled by 'force and fear'. He characterizes them as 'no more than boorish gangsters', who controlled 'gangs of bandits'. ${ }^{95}$

91 Donald Rumsfeld, Department of Defence News Briefing, April 22, 2002 http://www.Defence. gov/transcripts/transcript.aspx?transcriptid=3410 (accessed 22/06/2011).

92 Tenet, At the Center of the Storm, 210.

93 Zakheim, A Vulcan's Tale, 181.

94 Author Interview with a US Military Commander, Washington DC, April 29, 2012; Author Interview with a Senior Defence Department Official, via telephone, Sydney to Colorado, July 15, 2013.

95 Abdulkader H. Sinno, Organizations at War in Afghanistan and Beyond (Ithaca: Cornell University Press, 2008, 267. 
Some officials within the US civilian agencies considered the warlord strategy to be a harbinger of insecurity. ${ }^{96}$ The State Department was also aggravated by the CIA's encroachment into the realm of diplomacy. The CIA collaborated with the Pakistani intelligence service (the ISI), for example, in an attempt to forge an anti-Taliban, Pushtun alliance. In 2010, the agency conducted meetings in Pakistan toward that end. These meetings were completely removed from the Rome talks, where the US delegation was headed by the State Department. Furthermore, by refusing to pressure favoured tribal leaders to disband their private militias, the CIA circumscribed the State Department's efforts at disarmament. USAID, meanwhile, believed that CIA teams compromised its development projects by supporting a range of local power brokers without consideration of their developmental record. ${ }^{97}$

By supporting the CIA in its vendetta against Al Qaeda, Afghanistan's warlords adopted Abraham Lincoln's adage: 'If you would win a man to your cause, first convince him that you are his friend'. Their cause, however, was no more than a hunger for power resting on a foundation of self-interest. A sycophantic show of support represented a crude mask worn in order to carve out zones of influence and authority, backed by the CIA's money and resources.

Many warlords made fraudulent claims regarding the location of Taliban fighters, in thinly veiled attempts to cement authority over their rivals. In Kandahar, for example, Gul Agha Shirazi acquired an intelligence monopoly, which he used to feed the CIA information that suited his own ends. According to a humanitarian worker in the province, he 'had learned how to exploit the CIA's blind faith in his judgment and their knee-jerk sensitivity to anything that could be described as a terrorist threat, to neutralize people he didn't care for'. In another case, Pacha Khan Zadran, a southern commander, successfully called in airstrikes on rival tribal authorities, or to terrorize Afghan villages, under the contrivance that they were Taliban targets. ${ }^{98}$ Other warlords openly opposed the Karzai regime and provincial governments, with which the civilian agencies had established a working relationship. The Afghan government's candidate for governor in Khost, for example, was successfully removed from contention by a CIA-backed strongman. CIA representatives also simultaneously supported rival factions with weaponry and resources. ${ }^{99}$

In summary, the warlord strategy proved to be antithetical to nation-building in Afghanistan. Each CIA-backed warlord had powerful ambitions and was prepared

96 This was an opinion put forward by many of the officials who were interviewed for this study.

97 Rashid, Descent into Chaos, 136; Author Interview with a Senior USAID Official, Washington DC, April 19, 2012.

98 Sarah Chayes, The Punishment of Virtue, Inside Afghanistan After the Taliban (New York: Penguin, 2006), 309; Amy Waldman, “Afghan Warlord's Rival links him to US attacks”, New York Times, January 3, 2002.

99 Rangin Spanta, "Afghanistan: Nation-Building in the Shadow of the Warlords and the "War on Terror'", in Jochen Hippler (ed.), Nation-building, A Key Concept for Peaceful Conflict Transformation? (London: Pluto Press, 2004), 73; Giustozzi, Empires of Mud. 
to use any means to see them fulfilled. They were corrupt, mercenary and violent strongmen, who engaged in torture and drug production. Across Afghanistan, warlords intimidated and suppressed the Afghan populace, which built further resentment toward the US occupation and helped strengthen the Taliban-led insurgency. As well as circumscribing the security efforts of the international community, the warlord strategy prevented the establishment of an effective legal apparatus and an authoritative national government.

\section{Conclusion}

Efforts to promote security in Afghanistan were plagued with problems related to divisions within the US state machinery. The State Department and the military establishment argued over US policy toward the ISAF, due to different interests and perceptions of its value as a mechanism for internationally generated security. The military displayed its power by ensuring that there would be no US contribution to the force in the first four years of nation-building. The Pentagon had emerged victorious in its first skirmish with the State Department, though this only served to fan the flames of conflict between the two organizations.

By comparison, the development of Afghanistan's National Army proved to be a relatively successful venture. It is an example of the difference a solid US commitment makes when not hampered by waves of discord. Placed under the exclusive jurisdiction of the military establishment, it was the only aspect of nation-building that harmonized with US military culture. The Afghan National Police programme, meanwhile, was subjected to blurred lines of authority and divergent interests. Efforts from the civilian and military realms to establish Afghanistan's police force failed to transcend bureaucratic boundaries. Within the US government, there were simply too many different captains attempting to steer the ANP ship. Primary responsibility for the ANP's training was divided between the INL and the Pentagon. The former failed to manage Dyncorp, the company to which it outsourced much of the training, while the latter inappropriately prepared the ANP for fighting the insurgency. US officials and soldiers in the field were aware of the problems that shadowed the ANP and their thoughts were relayed to Washington. Such opinions were either ignored, or were unacknowledged, which created more turmoil within their respective agencies.

Finally, the CIA's interests in Afghanistan were not only disconnected from other US agencies, but also highly damaging to Afghanistan's political future. By pursuing the warlord strategy, the agency stepped beyond the bounds of intelligence gathering and into the realm of nation-building. The Pentagon supported the CIA, while the civilian agencies and many US soldiers in the field perceived it to be highly damaging to the nation-building mission. All of this spoke of a disunited US approach to security in Afghanistan, at an inter- and intra-agency level. The United States failed to generate a whole-of-government approach, which when combined with already difficult domestic circumstances, and discord within the NATO alliance, meant that nationwide security for the Afghan people never materialized. 


\section{Infrastructure Development}

Much like security, infrastructure development in Afghanistan was a significant challenge for the United States. In 2004, the US allocated \$1.76 billion for reconstruction, and funding increased considerably each year thereafter. From 2001 to $2010, \$ 26$ billion was invested in infrastructure projects across the country. Despite this spending, in December 2010 the Human Development Index, which orders countries in relation to their state of development, ranked Afghanistan at 155 out of 169 countries. Nearly half of Afghans still lived in poverty, two-thirds were without adequate sanitation, and most did not have access to safe drinking water. $^{1}$

Notwithstanding its lack of experience, the military establishment controlled a substantial portion of the funds dispersed by the US Government. Its approach to development has been widely criticized. The Special Inspector General for Afghanistan (SIGAR) argues that in some areas close to half of its projects 'were at risk or have questionable outcomes'. ${ }^{2}$ USAID implemented the majority of civilian infrastructure projects, but its approach was also problematic, albeit for different reasons, which are outlined below. The State Department controlled the remainder of the money allocated for reconstruction. Although the Department of Agriculture and the Department of Treasury were involved, it was usually only in an advisory capacity.

This chapter discusses the chaotic nature of US efforts to pursue reconstruction in Afghanistan. First it examines the US military's approach to infrastructure development. Second, it explores USAID's leadership on the civilian side and the controversy that this generated. Third, specific infrastructure projects in three areas - road-building, agriculture and education - are inspected. Finally, the impact that regulation and oversight from the counter-bureaucracy and Congress had on reconstruction projects is assessed.

1 United States Government Accountability Office, Afghanistan Reconstruction: Deteriorating Security and Limited Resources have Impeded Progress; Improvements in US Strategy needed, GAO, Washington DC, 2004; Special Inspector General for Afghanistan Reconstruction (SIGAR), Quarterly Report to the United States Congress, January 30, 2011, i; United Nations Development Program (UNDP), Human Development Report, April, 2010, 50.

2 SIGAR, Quarterly Report to the United States Congress, i. 


\section{The Military Establishment's Programme}

From 2001 to 2003, the military establishment was not interested in infrastructure development. It restricted itself, in the main, to military affairs. The intensification of the insurgency, however, led the Pentagon to perceive development as an important weapon in its counter-insurgency arsenal. After his appointment in 2006, the new Secretary of Defence, Robert Gates, was forced to respond to mounting military casualties in Afghanistan, which had triggered criticism of the occupation from Congress and the US media. He did so, in part, by arguing that the US military now recognized the significance of roads, medical clinics, schools and agricultural projects for winning the 'hearts and minds' of the Afghan populace. With this shift in attitude from the military leadership, at least rhetorically, some US soldiers in the field came to accept that they had broader interests in Afghanistan than simply combat operations. ${ }^{3}$

To implement an effective nation-wide strategy, Gates and other senior US officials called for a whole-of-government approach to infrastructure development, which blended civilian expertise with military strength. Yet in practice the military leadership eschewed involvement in civilian projects if it perceived them to be disconnected from the war against the Taliban-led insurgency. This contrasted with Kosovo and Bosnia, where civilian officials, who had been deployed to organize reconstruction efforts in volatile conflict regions, were supported by the US military. In Afghanistan, the military did not want to subordinate itself to playing a support role to the civilian agencies. The consequence was that the Pentagon sought to avoid providing security for civilian reconstruction projects. A Senior State Department Official contends that,

The Defence Department couldn't understand the argument that you needed some degree of security before you could expand reconstruction. They simply weren't inclined to provide the security and, therefore, were inclined to find whatever argument they could against it. ${ }^{4}$

Despite a substantial increase in US troop numbers from 2006 to 2010 the military failed to stop the Taliban's disruption of development projects undertaken by the State Department and USAID. Consequently, USAID officials and contractors were murdered by the Taliban in increasing numbers and, as the conflict in Afghanistan deepened, civilian projects were shelved in key areas such as agriculture, roads, schools, hospitals, water supplies and power. The US military also destroyed infrastructure projects in bombing campaigns and combat operations, but then refused to help rebuild or even provide financial compensation

3 Robert Gates, "A Balanced Strategy: Reprogramming the Pentagon for a New Age", Foreign Affairs 88:1 (2009); Scott Peterson, "In Afghanistan, Troops Tackle Aid Projects - and Skepticism", Christian Science Monitor, October 2, 2006.

4 Author Interview with a Senior State Department Official, Washington DC, April 15, 2012. 
for what was lost. This drew fierce protest from both the civilian branches of the foreign policy bureaucracy and from the Afghani Government. ${ }^{5}$ A collaborative approach to infrastructure development clearly remained unimportant to the military establishment when juxtaposed with combat operations against the Taliban.

A lack of faith in the civilian branches, combined with an increased emphasis on counter-insurgency as the Taliban-led resistance to the international presence in Afghanistan intensified, led to the creation of the Commanders' Emergency Response Program (CERP). CERP gave US soldiers a new role to fulfil in combination with war fighting. From 2004 to 2010, the programme allocated \$2 billion worth of funds to low-level US commanders to undertake small-scale infrastructure development projects. Around 16,000 of these 'quick impact projects' were completed by 2011 , the costs of which ranged from $\$ 5,000$ to $\$ 500,000$. Dov Zakheim, the Undersecretary of Defence from 2001 to 2004, argued that CERP was 'a very powerful tool for the military commanders in carrying out their current security and stabilization mission'. The military establishment had branded CERP as a comprehensive and far-reaching programme that responded 'to urgent humanitarian relief and reconstruction requirements'. ${ }^{6}$ Such rhetoric, however, was a veneer that disguised its true purpose.

Despite the diversity of the projects that were undertaken using CERP, the motive behind them all was to counter-balance the influence of the Taliban. Rather than being an aspect of nation-building, CERP, and also the larger infrastructure projects initiated by the Pentagon, were tools for winning a war. General David Petraeus, the most prominent advocate of COIN within the US military, bluntly stated that 'money is our ammunition'. Official military documents applied this description to their training regime. A US Forces Manual, which explained CERP to military officers, was titled 'Money as a Weapons System in Afghanistan'. 'Funding initiatives to win hearts and minds', according to another military report, complemented a priority to 'hunt enemies', both of which fell within the paradigm of 'an unorthodox phase of war'?

By adhering to this paradigm, the military perceived infrastructure projects outside conflict-ridden provinces to be unwarranted. Moreover, as the battlefront against the Taliban-led insurgency was amorphous, US soldiers were rarely a lasting presence in any given area of Afghanistan, which truncated the military's

5 Carlotta Gall, "NATO’s Afghan Struggle: Build, and Fight Taliban”, New York Times, January 13, 2007.

6 SIGAR, Quarterly Report to the United States Congress; United States Armed Forces (USAF), Commanders Emergency Response Program: Money as a Weapons System in Afghanistan, December, 2009, 12; Mark Martins, "No Small Change of Soldiering: The Commander's Emergency Response Program in Afghanistan and Iraq", The Army Lawyer, February 2004, 12.

7 Dennis Steele, "The Race to Win", ARMY, November, 2003, 10-11; Joshua Hersh, "Afghanistan: The Long and Winding Roads", Huffington Post, October 9, 2012, http:/www.huffingtonpost. com/2012/10/12/afghanistan_n_1951668.html (accessed 20/2/2012); Martins, "No Small Change of Soldiering: The Commanders Emergency Response Program in Afghanistan and Iraq", 2. 
reconstruction efforts. Two medics from New Hampshire who served with the Alabama National Guard, for example, gained the trust of the locals through the construction of a medical clinic. But the clinic did not outlive their departure. Lt David Patton, who was involved in a bridge building project in the village of Solan, noted that 'everyone believes in the mission', but admitted with resignation that 'there's an underlying thought that when we leave, it'll go back to the way it was'. ${ }^{8}$

CERP was not without its critics in the Pentagon. A DoD official criticized the ability of US soldiers to appraise infrastructure projects: 'Let's say the project is not working', he stated, 'why would we want to fund that project again the next year? Very little evaluation was done to decide what we fund next'. ${ }^{9}$ Another Pentagon staffer came to the realization that there was a disconnect between the overall strategic objective and what was being done on the ground and 'a lot of overlap because you could have a CERP project essentially duplicating an AID project in the same village'. In other cases, US commanders used CERP funds to provide military equipment to local leaders in return for their support of operations against the Taliban. Ironically, such actions sometimes resulted in the US augmenting Taliban units by giving money to their tribal associates and allies. ${ }^{10}$

Not content with abandoning the civilian agencies, the Pentagon attempted to modify the civilian programmes so that they reflected the priorities of COIN. The Afghanistan Reconstruction Group (ARG), which consisted of DoD bureaucrats, was created to oversee development projects. Each of its business-minded officials monitored an area of infrastructure development. Although forged by the Pentagon, these officials were ensconced within the State Department, and had a direct line of communication with the US Ambassador. This, according to one USAID contractor, made them more influential than the agencies they advised. ${ }^{11}$

The ARG formed a new and unwelcome faction within the State Department's bureaucracy, which rejected the perceived encroachment of the military establishment. A former US Ambassador recalled that planning meetings between civilian officials were subject to bickering and infighting: 'Within my embassy, the Afghan Reconstruction Group and USAID experts had differences of opinion, which were magnified by disputes over who should lead', he observed. ${ }^{12}$ The ARG claimed that the civilian agencies had mismanaged education and health

8 Larry Minear, The US Citizen-Soldier and the Global War on Terror: The National Guard Experience (Meford: Tufts University, 2007), 44; Elizabeth Rubin, "Taking the Fight to the Taliban", New York Times, October 29, 2006.

9 Josh Boak, "US Funded Infrastructure Deteriorates Once Under Afghan Control, Report Says", Washington Post, January 4, 2011.

10 Author Interview with a Senior Defence Department Official, via telephone, Sydney to Colorado, July 15, 2013; Abdulkader H. Sinno, Organizations At War in Afghanistan and Beyond (Ithaca: Cornell University Press, 2008), 264.

11 Joel Hafvenstein, Opium Season: A Year on the Afghan Frontier (Guildford: Lyons Press, 2007), 64.

12 Author Interview with a former US Ambassador to Afghanistan, Washington DC, April 18, 2012. 
programmes, and that projects were behind the quarterly indicators. This rationale was used as an excuse to steer projects toward Afghan provinces where the insurgency was strongest. The ARG also admonished USAID's preference for Afghan construction companies - a standard widely adopted by the development community, but one that inevitably caused delays. A Senior USAID Official considered this to be 'completely dysfunctional . . . which distorted what we were doing'. He claimed that it increased the animosity between civilian agencies and the military establishment, and witnessed clashes between the State Department and ARG in Kabul and acrimonious battles between USAID and the ARG in Washington during NSC meetings. ${ }^{13}$ The ARG then declared that USAID was misusing resources and manipulating reports, and related this discovery to the DoD and State Department. A USAID official observed that 'we found ourselves in friendly fire bureaucratically'. ${ }^{14}$ Clearly, the military's attempts to navigate development toward COIN only increased the tension between the USAID, the ARG and the State Department.

While the Pentagon was quick to shift US resources toward the counterinsurgency campaign, it often failed to consider the opinions of soldiers in the field. Many of these soldiers had, through their on-the-ground experience, attuned themselves to the needs of the Afghan populace. Special Forces Captain Rusty Bradley filled the role of 'diplomat, peace-maker [and] teacher' and argues that Afghanistan 'needed security, education, organization, honest political representation, and civil infrastructure'. Army Sergeant Jeff Courter contends that security, roads and education were crucial for winning the hearts and minds of the Afghans. 'I can't count the number of times villagers would express their need for roads, wells, seeds and animal medical services to us', another soldier stressed, describing medical clinics as 'the most powerful weapon in winning this war'. In Karawaddin, a US officer organized the distribution of winter coats and gloves to children, which were much needed items to fight a particularly harsh winter in 2007, while an army unit in another part of the country exhorted the US populace to ship school supplies to Afghanistan. ${ }^{15}$

Some soldiers with experience in the field argued that the absence of long-term planning and support from Washington hampered progress. Captain Leo Docherty, for example, believed that there had been no coherent plan beyond combat operations in Helmand, after which he received 'disjointed ill-considered directives from headquarters'. He considered the Pentagon's reconstruction plans to be nothing more than a mirage. In another case, a shipment of computers to Afghan civilians and translators was halted by the Pentagon under the justification that they would either sell or steal them. This was a claim which Lieutenant Benjamin

13 Author Interview with a Senior USAID Official, Washington DC, April 19, 2012.

14 Strimling Yodsampa, No One in Charge: A New Theory of Coordination and Analysis of US CivilMilitary Coordination in Afghanistan (Unpublished Dissertation, Tufts University, 2009), 169.

15 Rusty Bradley, Lions of Kandahar, 9; Courter, Afghan Journal, 135 and 277; C.J. Chivers, "On Taliban Turf, Lines of Ailing Children". New York Times, December 12, 2007. 
Tupper, a soldier in the field, rejected. He believed that the real reason behind the Pentagon's lack of support was that it was not interested in infrastructure development in peaceful areas, which it considered to interfere with the primary goal of vanquishing the enemy. Tupper resented the mentality of a military leadership who were unable to recognize that the Afghans were capable of progress. ${ }^{16}$

Not all US soldiers were sensitive to the benefits of local infrastructure development. An Afghan translator recalled one incident where US soldiers 'while trying to level a training area, decided to dump dirt inside a hole that belonged to local irrigation systems', which had a punitive effect on the quality of life of the local populace. There were also procedural problems that came with this unfamiliarity. In Kandahar, Lt. Col. Brian Stoll struggled to make sense of the database for infrastructure projects that had been left by his predecessors: 'We never got it all cleaned up', he stated, 'it was like a Hydra, you get part of it cleaned up and you find some more along the way'. ${ }^{17} \mathrm{COIN}$ failed to adequately promote the ideas of soldiers who perceived development to be important, nor did that strategy sufficiently consider the impact that other soldiers, who were unable to recognize a role beyond war fighting, had on nation-building.

\section{USAID's Programme}

Infrastructure development abroad is well within USAID's area of expertise. Hence, the agency appeared to be the natural choice to head the civilian reconstruction programme in Afghanistan. The scale of the challenge, however, was not something which USAID typically had to deal with. In 1977, 100 of its officials managed an annual budget of $\$ 25$ million, monitoring roughly $\$ 250,000$ worth of projects each. But in 2004, 60 officials managed over $\$ 500$ million, which amounted to $\$ 8$ million per official. USAID endeavoured to embrace this drastic increase in responsibility. In Helmand province, it oversaw the completion of an airport, doubled the electricity output and, through agriculture projects, reduced poppy production by one-third. In 2010, it completed 780 cash-for-work projects, employed 103,000 labourers and injected \$27 million in wages into the Afghan economy, which was the equivalent of 225,000 full-time jobs. ${ }^{18}$ Yet for every successful project, there were many more failures, not all of which can be blamed on USAID alone.

Progress in the first few years of nation-building was slow, but in 2005, with the support of the State Department, USAID vowed to increase power access from 6 per cent to 40 per cent of Afghanistan's population, and implement a national

16 David Loyn, In Afghanistan: Two Hundred Years of British, Russian and American Occupation (New York: Palgrave Macmillan, 2009), 223; Tupper, Greetings from Afghanistan: Send More Ammo, 136-137.

17 Chayes, The Punishment of Virtue, 142; Boak, "US Funded Infrastructure Deteriorates Once Under Afghan Control, Report Says".

18 David Rohde, "Little America: An Afghan Town, an American Dream and the Folly of For-Profit War”, Reuters, June 1, 2012; SIGAR, Quarterly Report to the United States Congress, 89. 
programme that employed young Afghans to improve the rural economy. ${ }^{19}$ Yet these and other ambitious commitments involved no solid or achievable plan through which to channel US resources or collaborate with other agencies toward common objectives. James Dobbins, the US Special Representative to Afghanistan, remembers that from the beginning, blurred lines of authority between USAID and the State Department resulted in conflict as the two agencies jostled for power in Washington:

The situation turned into a classic Washington turf battle, all about status and prerogative. When Armitage proved unwilling to overrule Natsios, responsibility for overseeing Afghan reconstruction remained divided among half a dozen State Department and USAID fiefdoms. ${ }^{20}$

For example, the decision as to whether the US should prioritize roads or agriculture involved months of debate.

Over the preceding decades, USAID's culture had regressed to focus on small, long-term projects. The agency did not have the capacity or the structural mechanisms to handle the number of requests its officers were making from the field. As a consequence, they went through the US Embassy in Kabul, with State Department officials closely monitoring USAID officers and often having the final say on many of their project proposals. This determined that the autonomy that USAID so desperately craved to fulfil its developmental mandate was severely compromised. One USAID official remembers that, 'everything had to go through Kabul in terms of decision-making . . . no discretion was given to the field program officer' ${ }^{21}$

Both agencies blamed each other for the mistakes and lack of judgement that their discord generated. In 2005, Phillip Bell, an official from the State Department, admonished USAID in an internal memo. He argued that because of poor management and planning, many development programmes were in trouble. The health programme, especially, was a disaster. Alternatively, Larry Sampler, a Senior USAID Official who operated in Afghanistan from 2001 to 2009, argued that the pressure the State Department placed on USAID for immediate results caused this 'disaster'. Such pressure meant that USAID did not have 'as robust a focus on sustainability as we would like'. Sampler maintained that sustainability was a core value of development. In so doing, he implied that this key consideration was something that the State Department did not understand. ${ }^{22}$

A new development initiative was put forward in 2008 by the United States Army Corps of Engineers. It revolved around the needed for a 'construction

19 Committee on Armed Services, Assessment of Security and Stability in Afghanistan and Development in US Strategy and Operations, House of Representatives, One Hundred Tenth Congress Hearing, February 13, 2007, 20.

20 Dobbins, After the Taliban.

21 Yodsampa, No One in Charge, 104.

22 Joe Stephens and David Ottaway, "A Rebuilding Plan Full of Cracks", Washington Post, November 20, 2005; Hersh, "Afghanistan: The Long and Winding Roads". 
surge' in Afghanistan, encapsulating a broader philosophy that quick-impact development was what the country required. The idea of front-line development appealed to Ambassador Inderfurth, the Assistant Secretary of State for South Asia, India and Pakistan, who considered this 'the right kind of surge right now in Afghanistan'. ${ }^{23}$ The State Department's support for the surge was a testament to its disconnect from USAID, and also another example of the military establishment's power to shape the course of Washington politics in order to complement its counter-insurgency strategy.

USAID, meanwhile, resisted shifting development to suit the military's interests. USAID preferred long-term nation-building befitting the target country's absorptive capacity. It did not support the faster and arguably more efficient projects that the State Department and military establishment deemed to be suitable for Afghanistan: 'I call it hijacking', one USAID official stated, 'aid as a weapons system has never been tested - and they are putting it into the field with no evidence that it works'. USAID's culture, moreover, did not prepare it for such an unorthodox approach to development. Patrick Fine, the agency's Mission Director in Afghanistan from 2004 to 2005, argued that it did not have the capacity or expertise to pursue the quick-impact projects that the construction surge called for. To support his assertion, Fine sited a problematic example in 2004 where the goal of 1,000 schools and clinics 'gained traction in Washington and soon became the number that USAID was required to build'. ${ }^{24}$ A USAID staffer who worked with Fine was similarly unconvinced that the rearrangement of developmental priorities to suit counter-insurgency would bear fruit. ${ }^{25}$

Although USAID continuously emphasized the need for a national development strategy, it was commanded by the White House, State Department and the military establishment to focus on areas that were the major battlefronts in the war against the Taliban-led insurgency. Consequently, from 2006 onwards USAID spent approximately three quarters of its budget a year in the southern provinces, such as Helmand and Kandahar. In 2010, it allocated \$250 million for infrastructure projects in those two provinces alone. In Helmand's Nawa district, the agency spent over $\$ 30$ million within nine months, in what was described as '[the] carpet bombing of Nawa with cash'. The substance of this spending was often 'quick impact' projects that complemented the military's counter-insurgency strategy. Programmes such as the District Delivery Program and the District Stabilization Framework were USAID's version of CERP. Similarly, the Regional Afghan Municipalities Program for Urban Populations (RAMP), an initiative by Zalmay Khalilzad, the US Ambassador to Afghanistan from 2003 to 2005, was 'a sort of reconstruction slush

23 Committee on Armed Services, Assessment of Security and Stability in Afghanistan and Development in US Strategy and Operations, House of Representatives, One Hundred Tenth Congress, Second session, January 23, 2008, p. 23.

24 Dion Nissenbaum, "Roads to Nowhere: Program to Win Over Afghans Fails", Wall Street Journal, February 10, 2012. http://online.wsj.com/news/articles/SB1000142405297020355410457665528 0219991322 (accessed 02/02/2013); Stephens and Ottaway, "A Rebuilding Plan Full of Cracks".

25 Author Interview with a Senior USAID Official, Washington DC, April 23, 2012. 
fund'. Khalilzad, a powerful figure with close ties to the White House, demanded that USAID undertake what he considered a politically essential project immediately, such as the Helmand cash-for-work project. These and other cash-for-work programmes lasted but a few weeks and usually failed to have a lasting impact. ${ }^{26}$

Nonetheless, projects like cash-for-work were popular among high-ranking State Department and Pentagon officials because, regardless of how effective they actually proved to be, they demonstrated a US commitment to development in Afghanistan's conflict-ridden southern provinces. USAID officials, however, had no experience of operating in such hostile conditions and often found it impossible to monitor their projects, let alone address their long-term development implications. Fine stated in a confidential memo that his agency's attempts to conduct these quick-impact projects in Afghanistan were 'marked by a series of missteps and miscalculations that resulted in a flawed business model, inadequate supervision and poor execution'. Pressure from outside forces also determined that USAID pursued grandly ambitious projects, even though, as Fine confirmed, it did not have 'a quality assurance plan or adequate staff to monitor performance' ${ }^{27}$

The most prominent of these projects was the repair and upgrade of the Kajaki Dam in Northern Helmand, at an estimated cost of \$500 million. The dam project, which began in 2004, ostensibly became the jewel of USAID's infrastructure development programme, although some of its officials shared Fine's reservations and questioned whether it made financial or strategic sense. Upon completion it was claimed that the dam had the ability to create enough power to light 1.7 million Afghan homes. An agency spokesperson described it as a 'critical element in our support for Afghanistan because it will provide the electricity to drive privatesector growth in Helmand and Kandahar'. But it was a massive and unrealistic undertaking that involved little coordination with the rest of the US government. Nor did USAID adequately account for the security environment in an area littered with drug lords and Taliban insurgents. The idea of building the dam was reasonable, but implementation was always going to prove costly, risky and time consuming. It was also well beyond the USAID's power to construct the dam without assistance. Eight years later, the Kajaki dam had still not been completed. Taliban attacks blocked the delivery of 900 tons of cement needed to complete the job, and the $\$ 5$ million turbine remained uninstalled. If there had been consultation with the State Department, in order to construct a realistic timetable for the dam's completion, and coordination with the military establishment to provide security for contractors and Afghan workers, the vast resources dedicated to the dam project could have been more wisely utilized. ${ }^{28}$

26 Vanda Felbab-Brown, "Afghanistan Trip Report VI: Counternarcotics Policy in Afghanistan: A Good Strategy Poorly Implemented”, Brookings Institute, Foreign Policy Trip Reports 41-58, May 10, 2012 http://www.brookings.edu/research/opinions/2012/05/10-counternarcoticsfelbabbrown (accessed 8/7/2013); Hafvenstein, Opium Season: A Year on the Afghan Frontier, 62.

27 Stephens and Ottaway, "A Rebuilding Plan Full of Cracks".

28 Jon Boone, "US Cuts Put British-Backed Afghan Hydropower Project in Doubt", Guardian, December 13, 2011; Aryn Baker, "A Dam Shame: What a Stalled Hydropower Project Says About 
In the face of mounting pressure to conform, USAID protected resources and independence and still endeavoured to apply some of its cultural norms. When a military commander asked a USAID officer, 'What is your strategy for province $\mathrm{X}$ ?', for example, he replied: 'We don't have a strategy for each province. That's not how USAID works. USAID has a strategy for the whole country':

They - the military - need specific activities - geographic-specific plans that they can help facilitate or participate in ... They would ask: 'What is your goal for Afghanistan?' [USAID would reply]: 'A healthy, stable Afghanistan that is no longer a threat'... . The military would rub their eyes and say, 'Great, but what do we do in the morning?' It required a big cultural bridge between the two organizations. ${ }^{29}$

It was 'a debate which had become quite polemical', according to Stuart Gordon, a British researcher: 'Development practitioners didn't like the military being involved in the quick-impact projects, and the military thought the development community had failed to deliver, and lives were being lost as a consequence', he states. $^{30}$

USAID relied heavily on contractors to implement its infrastructure development programme - for three reasons. First, unlike the military establishment, it did not have the power, in terms of resources and staff, to undertake large-scale development. Second, the use of contractors had been standard practice for USAID and was a key component of its activities globally. Third, the quick-impact projects that the State Department and military establishment craved were antithetical to the agency's culture. To fulfil them it appealed to US, international and Afghan companies, each of which recognized that USAID had deep pockets. Hence, they voraciously competed for lucrative, short-term contracts. ${ }^{31}$

Ironically, although USAID resisted the encroachment of other agencies into its traditional realm of responsibility, it depended on outsourcing. The agency had little control over its contractors, many of which had no substantial experience or expertise in implementing infrastructure projects - especially ones that would be appropriate for Afghanistan. USAID contractors left a graveyard of unfinished schools, roads, power supplies and medical clinics. They also managed to spend a lot of money on subcontracting in a way that was generally considered by those on the ground to be extremely wasteful. One particularly damning report stated that outsourcing resulted in large sums of aid money being transformed into

Failures in Afghanistan" Time, December 15, 2011; Carlotta Gall, "Building a Dam in a Bid to End Afghan Instability", New York Times, September 18, 2007; Rohde, "Little America: An Afghan Town, an American Dream and the Folly of For-Profit War".

29 Yodsampa, No One in Charge, 265.

30 Hersh, "Afghanistan: The Long and Winding Roads".

31 Hafvenstein, Opium Season, 240. 
corporate profits. ${ }^{32}$ An observer in the field revealed that an engineer hired by one of USAID's contractors to implement a $\$ 700,000$ project to construct 19 small irrigation dams 'was incompetent, did not understand English and submitted an initial design that was "a crappy little drawing", During a five-year contract, another of the agency's contractors spent $\$ 4$ million just on the salaries of foreign agents. $^{33}$

USAID's primary contractor for infrastructure development was the US Company Louis Berger Group Incorporated (Berger), which had contracts worth over $\$ 665$ million. Most of the money it had received was mismanaged. Marshall F. Perry, a construction manager at Berger, stated that his company 'didn't have the staff to read the reports, let alone respond with site visits'. He admitted that the entire program was 'a calamity'. Berger's subcontractors were found to have used poor materials and substandard methods, but still charged exorbitant fees for their work. One such subcontractor had the temerity to steal $\$ 141,000$ worth of materials. Eventually, USAID realized its misplaced faith and outsourced much of Berger's responsibility to a number of non-profit relief organizations. A diplomatic cable revealed that USAID 'always had doubts about the ability of the single original contractor . . . to complete all schools and clinics on the former schedule'. ${ }^{34}$

Chemonics replaced Berger as USAID's largest private contractor, aided (allegedly) by its ability to cut corners and manipulate figures. ${ }^{35}$ Joel Halfeinstein, a developmental expert working for USAID and Chemonics, ${ }^{36}$ argues that his company's subcontracting problems were similar to Berger's. ${ }^{37}$ In Kandahar, USAID gave millions of dollars to Chemonics, which then hired a series of subcontractors to carry out infrastructure development projects. But neither USAID nor Chemonics had sufficient oversight capacity to monitor their activities in the province. Meanwhile, in Lashkargah, USAID subjected Chemonics' subcontractors to more scrutiny. This generated a dispute between the agency and a subcontractor, which delayed the construction of a number of infrastructure projects. ${ }^{38}$

USAID was severely criticized for outsourcing projects to Berger, Chemonics and other contractors, but then failing to sufficiently monitor their activities. Incredibly, due to staff shortages within the agency, former contractors morphed into USAID representatives: 'the agency was so short on personnel that it hired contractors to monitor its contractors'. According to a report from the Office of the Inspector General, many USAID officials could not identify the locations of

32 Author Interview with a Senior State Department Official, Washington DC, April 30, 2012; Carlotta Gall, "Afghanistan Lacks \$10 billion in Aid Report Says”, New York Times, March 26, 2008.

33 Rohde, "Little America: An Afghan Town, an American Dream and the Folly of For-Profit War"; Sarah Chayes, "A Voice From Kandahar: Tangled in Red tape”, New York Times, July 30, 2006.

34 Stephens and Ottaway, "A Rebuilding Plan Full of Cracks".

35 Pratap Chatterjee, "Paying off the Warlords: Anatomy of a Culture of Corruption", in Nick Turse (ed.), The Case for Withdrawal from Afghanistan (New York: Verso, 2010), 82.

36 Confusingly, many development workers wore these two hats simultaneously.

37 Hafvenstein, Opium Season, 62.

38 Chayes, "A Voice From Kandahar: Tangled in Redtape". 
their infrastructure projects. Some of them, such as Catherine Mallay, were not even aware of which contractors were financing which projects. In other cases, contractors were directed by USAID to build at locations that were dry riverbeds, graveyards or sheer mountain slopes. ${ }^{39}$

Clearly, USAID was out of its depth in Afghanistan, yet it aggressively protected its interests. Its officers tenaciously clung to the conviction that they were the development experts and, consequently, the most appropriately qualified to oversee infrastructure development. But USAID did not have the power to manage and monitor the contractors that it hired. These contractors, which existed in the porous border region between the private sphere and the foreign policy bureaucracy, added another layer of conflict and confusion to an already divided nation-building effort.

\section{Infrastructure Development Projects}

Specific development projects illustrate the depth of bureaucratic divisions discussed above. In 2001, Afghanistan had less than 80 kilometres of paved roads. A major component of US nation-building was to create a road network that would help ensure security, facilitate trade and augment other infrastructure projects. The importance of road-building was promoted by officials within the State Department and the military establishment. Daniel Dunleavy, a member of the United States Army Corps of Engineers (USACE), stated that, 'if you give people mobility, you bring in prosperity'. Collaborative projects, such as the Khost-Gardez road, were perceived by William Wood, the US Ambassador to Afghanistan from 2007 to 2009 , to be as 'fully-integrated a civ-mil project you can find'. Similarly, James McConville, a US general who served in Afghanistan in 2009, claimed that road-building was a 'flagship program with interagency results'. ${ }^{40}$

The apparent agreement on the importance of road-building, however, concealed differences in approaches to the task, particularly between the military and the State Department on the one hand, and USAID on the other. Andrew Natsios, the USAID Administrator from 2001 to 2006, argued for the need to prioritize road-building projects as a necessary foundation for other infrastructure projects, citing his agency's activities in Northern Thailand in the 1970s as an example of

39 Joel Brinkley, "Money Pit: The Monstrous Failure of US Aid to Afghanistan”, World Affairs, January/February, 2013; Rohde, "Little America: An Afghan Town, an American Dream and the Folly of For-Profit War"; Michael Carroll, Most Serious Management and Performance Challenges for the US Agency for International Development, Office of the Inspector General, 2013; Stephens and Ottaway, "A Rebuilding Plan Full of Cracks".

40 Kevin Sieff, "After Billions in US Investment, Afghan Roads are Falling Apart", Washington Post, January 21, 2014. http://www.washingtonpost.com/world/asia_pacific/after-billions-inus-investment-afghan-roads-are-falling-apart/2014/01/30/9bd07764-7986-11e3-b1c5739e63e9c9a7_story.html (accessed 21/01/2014); Tony Wickman, "New Afghan Roads Promote Peace, Prosperity", United States Department of Defence, September 23, 2009; Yodsampa, No One in Charge, 256-257. 
where this had previously been successful. ${ }^{41}$ But the agency resisted when the State Department and the military establishment foisted responsibility for large road-building projects onto USAID. Grand and ambitious highways, which stretched across Afghanistan's wild and barren rural landscape, were beyond its area of interest and its capability. USAID's culture did not prepare it for the creation of these sprawling arteries, and it lacked the resources, manpower and expertise that such projects required.

The type of road-building that the State Department and military establishment advocated was a far cry from the gradual and localized road-building initiatives USAID had previously pursued in Thailand and elsewhere. They were also out of step with USAID's preference for community-based, locally driven enterprises. To attune road-building to its interests, therefore, it initiated the Strategic Provincial Roads Project (SPRP) in November 2007, which helped build wells, small soap factories, sewing clinics and reading programmes for illiterate villagers. ${ }^{42}$ Through SPRP and other similar initiatives, USAID officials in the field infused their perception of best practice into US road-building projects, in order to suit the agency's broader nation-building agenda. Jeff Grieco, a USAID official, recalls one instance that encapsulated USAID's mentality:

This was never intended to be a major road construction project. It was intended to be a capacity building program. We have dramatically improved Afghan capacity to build roads and to do community development work. ${ }^{43}$

Adhering to these preconceived perceptions was often problematic and was indicative of what Strachan dubbed 'the lost meaning of strategy', whereby a lack of strategic clarity determined that agency culture and interests shaped policy, rather than any broader intragovernment conception of developmental priorities. ${ }^{44}$ Many inappropriate projects were undertaken that did not reflect the situation on the ground. In 2005, for example, USAID hired 11 Bolivian cobblestoners to teach locals in Helmand. The locals, however, had driven on asphalt roads for three decades and the project left them, and US military officials operating in the area, bewildered. In another example, USAID distributed 300 solar panels to shopkeepers in Kandahar, but ignored the fact that none of their shops were wired to use electricity. ${ }^{45}$

41 Andrew Natsios, "Time Lag and Sequencing Dilemmas of Post-conflict Reconstruction", PRISM, $1: 1(2009), 72$.

42 USAID, Fact Sheet: Strategic Provincial Road-Southern and Eastern Afghanistan, Kabul, June, 2011.

43 Nissenbaum, "Roads to Nowhere: Program to Win Over Afghans Fails".

44 Hew Strachan, "The Lost Meaning of Strategy", Survival, 47:3 (2005), 52.

45 Rohde, "Little America: An Afghan Town, an American Dream and the Folly of For-Profit War"; Joel Brinkley, "Millions More Squandered by USAID in Afghanistan", World Affairs Journal, Online Blog, June 28, 2013 http://www.worldaffairsjournal.org/blog/joel-brinkley/millions-moresquandered-usaid-afghanistan (accessed 28/6/2013). 
When USAID did attempt to engage in more ambitious road-building projects it often failed to complete them. In 2009, it was given $\$ 400$ million to construct 2,000 kilometres of roads in Afghanistan's conflict-ridden southern provinces. But after three years and with $\$ 270$ spent, it had completed less than 160 kilometres of roads. The termination of failing projects, meanwhile, proved to be difficult due to the complicated network of contractors and subcontractors to which it had outsourced road-building projects. A handful of USAID officials were spread across more than half-a-million square kilometres, and they struggled to engage in oversight without compromising the projects themselves: 'How quickly can you stop a dump truck?' one agency official asked; 'You get the momentum going and one thing we committed to doing isn't stopping it and creating a wreck' ${ }^{46}$

According to a GAO report, USAID lacked the funding, data collection capabilities and an assessment framework to evaluate projects and monitor its contracts. ${ }^{47}$ USAID 'cannot conduct serious oversight', one military officer claimed after witnessing the sorry state of one of its road-building projects. He described it as 'a shell of its former self', and 'just a big contracting mechanism'. USAID's approach ensured that roads moved 'at a pace that made a snail's gait look like a greyhound's'. It also allowed contractor's to put their profits before all else. In 2007, the Khost-Gardez highway was contracted to two US companies, the aforementioned Louis Berger Group and Black \& Veatch. Berger hired a cheap but inexperienced Indian subcontractor to handle the construction, and another private security contractor, ISS-Safenet, to provide security for the project. Both of these subcontractors in turn employed Afghan strongmen and militia to accrue influence in the region and enforce order. Much like the CIA's warlord strategy, all this did was empower forces that sowed disorder and turmoil. In November 2010, Berger was tried by the Commission on Wartime Contracting and forced to pay one of the largest fines ever to the US government for overbilling. ${ }^{48}$

Roads were another important component of the US programme. For the military establishment, roads enhanced troop mobility, shifted the influence in a given area from the Taliban to the United States, and reduced the potency of Improvised Explosive Devices (IEDs). ${ }^{49}$ All three of these factors improved its combat operations. Accordingly, the Pentagon often funnelled funds from USAID or the State Department infrastructure projects, in pursuit of what it considered to be a

46 House of Representatives, Proceedings and Debates of the 112th Congress, Second Session, Vol. 128, No. 26, Washington DC, February 16, 2012; Nissenbaum, "Roads to Nowhere: Program to Win Over Afghans Fails".

47 Government Accountability Office, Afghanistan Reconstruction: Progress Made in Constructing Roads but Assessments for Determining Impact and a Suitable Maintenance Program Are Needed, GAO, Report to Congressional Committees, July, 2008.

48 Allissa Rubin and James Risen, "Costly Afghanistan Road Project is Marred by Unsavory Alliances", New York Times, May 1, 2011; Zakheim, A Vulcan's Tale, 267; Rubin and Risen, "Costly Afghanistan Road Project is Marred by Unsavory Alliances".

49 Tony Wickman, "New Afghan Roads Promote Peace, Prosperity", American Forces Press Service, United States Department of Defence, September 23, 2009. 
more important allocation of US resources: highways. One example of this was its demand for the construction of a highway in the insurgency-ridden province of Urugan, in early 2005. This led a USAID official to contend that the 'the reason USAID builds roads is economic growth or employment', but 'the reason the military builds roads is to penetrate enemy territory'. ${ }^{50}$ Another of the agency's officials complained that due to the influence of COIN, road-building was driven by

military or politically driven timelines and locations which make no sense, or which force us into alliances with the very same malign actors that are powerfully part of the broader battles we are fighting. No one steps back and looks at the whole picture. ${ }^{51}$

The military perceived its obligation to be over once a road was completed, and it failed to monitor the roads that had been constructed: 'There was such an urgent need to build highways', a US official recalls, 'maintenance was not the issue at the time'. ${ }^{2}$ Despite committing CERP funds to build 16,000 kilometres of roads by the end of 2010, the DoD did not report any data to USAID or Congress on the details of their construction, nor did the Pentagon conduct proper project evaluations. $^{53}$

Eikenberry points out that 'whenever the roads end, that's where the Taliban begins'. ${ }^{54}$ This was not quite accurate. Due to poor security, roads became prime targets for the Taliban. Nonetheless, rather than securing roads the US military used them (almost) exclusively as a way of moving between conflict-ridden provinces. When a plan was announced in September 2002 to rebuild the highway between Kabul and Kandahar, the State Department successfully lobbied the Japanese government to contribute to its reconstruction. The Pentagon, however, refused to deploy any of the 3,000 troops it maintained in Kandahar to protect Japanese engineers. Thereafter, to the State Department's dismay, a large number of international engineers with expertise to significantly improve Afghanistan's horrid road system were forbidden by their respective governments from being deployed. ${ }^{55}$

The US military did little to prevent insurgent attacks on USAID's road construction sites, which destroyed vehicles and killed workers. By March 2008, 162 USAID contractors engaged in road-building projects had been killed. This forced USAID to shut down many of its road-building projects. The Khost-Gardez highway cost significantly more because USAID was obliged to spend $\$ 43.5$ million

50 Hafvenstein, Opium Season, 163; Yodsampa, No One in Charge, 198.

51 Rubin and Risen, "Costly Afghanistan Road Project is Marred by Unsavory Alliances".

52 Sieff, "After Billions in US Investment, Afghan Roads are Falling Apart".

53 Government Accountability Office, Afghanistan Reconstruction July 8, 2008, http://www.gao. gov/assets/280/278015.pdf

54 Peter Bergen, Defeating the Attempted Global Jihadist Insurgency, New America Foundation, July 2008. http://newamerica.net/node/8924 (accessed 17/03/2013).

55 Barnett Rubin and Ahmed Rashid, "SOS from Afghanistan”, Wall Street Journal, May 29, 2003. 
on security contractors and local strongmen who, it turned out, were powerless to prevent Taliban attacks. ${ }^{56}$ Regardless, the military placed the blame on USAID and its contractors for Afghanistan's crumbling highways and roads, without reflecting on its own contribution to their degradation and insecurity.

US efforts at agricultural development were similarly controversial. Compared to the rest of the US government, USAID had an alternative perception of what agricultural reform required in Afghanistan. The agency planned 150 programmes, from 2001 to 2010 , that focused on approximately 13 fertile agricultural areas. ${ }^{57}$ They involved the extension of agricultural services, land-grants, university programmes, partnerships with the private sector, and access to capital for agribusiness, through loan-guarantee schemes. USAID wanted to provide access to material and technology as well as deliver expertise to help produce high value commodities such as fruits, vegetables and tree crops. In other words, it wanted to facilitate what it considered to be the best methods for promoting commercial agricultural growth, in order to improve the economy and increase opportunities for employment. Concentrating US funds and resources on stable and productive areas in the middle of Afghanistan was, USAID argued, the most effective conduit for US funds. Those geographical locations had a long tradition of bountiful harvests, and already had large agrarian systems in place. Yet despite its commitment to agricultural reform, USAID essentially ignored traditional land rights and patterns of tenure, much as the Soviets had done in the 1980s. Overtime, this brought about resistance from local landholders, and impeded the implementation of many USAID agricultural projects. ${ }^{58}$

The agency's agricultural projects also came up against State Department and military interests. The State Department prioritized a narrowly focused, counternarcotic strategy. The military, meanwhile, demanded that agriculture projects be focused on the southern provinces, where the Taliban-led insurgency was strongest. When these competing interpretations were expressed simultaneously in a National Security Council (NSC) meeting, they frustrated one Senior USAID Official:

Do you want to defeat the insurgency? Do you want to stop poppy production? Or do you want us to pursue development that counts? Because they are not the same thing... ${ }^{59}$

56 Mohammad Abi Amiri, "Road Reconstruction in Post-Conflict Afghanistan: A Cure or a Curse?", International Affairs Review, 11:2 (2013), 9.

57 Author Interview with a Senior USAID Official, Washington DC, April 19, 2012.

58 Curt Tarnoff, Afghanistan: US Foreign Assistance, Congressional Research Service, Washington DC, August 12, 2010, 6; Liz Wily, Land Rights in Crisis: Restoring Tenure Security in Afghanistan, Afghanistan Research and Evaluation Unit, 26 February, 2009; Liz Wily, Looking for Peace on the Pastures: Rural Land Relations in Afghanistan, Afghanistan Research and Evaluation Unit, 26 February, 2009.

59 Author Interview with a Senior USAID Official, Washington DC, April 19, 2012. 
In a subsequent NSC meeting, he sardonically quipped that the only way he could envisage these inter-departmental goals coalescing would be to move the geographical location of Afghanistan. ${ }^{60}$

As his experience illustrates, powerful bureaucratic forces attempted to sway the course of USAID's agricultural programme. The State Department, along with many congressmen, pressured USAID to link agriculture to counter-narcotics. In order to placate them, USAID initiated the Alternative Livelihood Program (ALP) in 2004, which allocated US funds to certain provinces to reduce poppy production. Ambassador Neumann considered the ALP to be part of a broader national strategy that used 'agricultural success to counter poppy production'. ${ }^{61}$ While he addressed the long-term nature of the enterprise, however, many of his colleagues in Washington and many in Congress perceived it to be an immediate panacea. This ignored the fact that, as a senior member of the United Nations Office on Drugs and Crime stated, 'the Afghan farmer will not switch to alternative crops as long as there is a market for his opium'. ${ }^{62}$

The State Department ensured that it was supported by the Afghan government, which called for the US to 'provide Afghan farmers with financial, material and technical resources for alternative crop production'. ${ }^{63}$ Although the US and NATO committed $\$ 119$ million toward the ALP in its first year alone, according to some estimates a mere $\$ 4$ million had actually been spent by $2005 \cdot{ }^{64}$ Nonetheless, funds did increase as the poppy problem worsened. In Helmand and Kandahar, in particular, larger sums of money were committed to ALP projects. The fact that the soil quality in these regions was poor and that the arid climate prevented effective crop production, was perceived by the State Department to be less important than the impact the ALP would have on the drug trade. ${ }^{65}$

USAID, however, resisted being typecast in a role with which it was unfamiliar. Its officials in the field decided to repel what they perceived to be the perversion of development, driven by the State Department's counter-narcotics obsession. Instead, influenced by the same culture that had provoked Natsios to upbraid his State Department and DoD colleagues in NSC meetings, they modified the ALP programmes to create small-scale economic projects for Afghans that were usually not linked to curtailing drug production. In this way, USAID incorporated the ALP under the banner of agricultural and economic development, a strategy that went beyond planting orchards and other licit crops to replace poppy fields. These projects involved cash-for-work-programmes, the distribution of fertilizer

60 Ibid.

61 Neumann, The Other War.

62 Donald D. McNeil, "Could Afghan Poppies be Pain Killers for the Poor?”, New York Times, October 14, 2007.

63 Alfred McCoy, The Politics of Heroin, CIA Complicity in the Global Drug Trade (Chicago: Lawrence Hill, 2003), 522.

64 Rashid, Descent into Chaos, p. 323.

65 Natsios, "Time Lag and Sequencing Dilemmas of Post-conflict Reconstruction", p. 65. 
and seed for crops, better irrigation and storage, a credit network and business platforms. USAID also considered economic conditions, market credit lines and the state of agriculture across the country, as well as technology, infrastructure and domestic and international markets for Afghan products. ${ }^{66}$

Predictably, USAID relied on contractors and neglected to closely monitor its agriculture projects. USAID 'did not make sufficient site visits to properly monitor the program and did not analyze progress reports or confirm their accuracy', the US Inspector General confirmed. ${ }^{67}$ Notwithstanding its laudable ambitions, the ALP programme not only failed to have a significant impact on Afghanistan's opium production, but also left a slew of unfinished ventures that languished among burgeoning poppy fields. When the agency hired contractors to build 370 kilometres of irrigation canals, for example, they managed only 40 . Another contractor was criticized by the US special Inspector General for spending tens of millions of dollars on 'foolish projects that accomplished nothing'. Appallingly, some USAID contractors reputedly rented their premises to major drug traffickers. These and other problems were scrutinized by Congress, which blamed USAID for 'putting in large contractors in Kabul who have limited connection with the people on the ground and the communities where the poppies are being produced in the largest numbers' ${ }^{68}$

A final issue was that the military establishment's lack of involvement in the ALP determined that many projects were plagued by insecurity. Successful projects that employed a large number of Afghans and helped promote growth, according to Hafvenstein, were hampered by a lack of security, resulting in the deaths of a number of USAID workers. He contended that the ALP 'cannot foster alternatives to opium while under fire' ${ }^{69}$ Indeed, in the absence of security measures, the programme was always going to have a limited chance of success. Yet neither USAID nor the military attempted to cooperate to produce a strategy that linked the ALP to COIN operations within Afghanistan's rural sphere. The comically named 'IDEA-NEW' programme replaced the ALP in March 2009. It was a five year, $\$ 150$ million enterprise that, once again, centred on the creation of economic opportunities as an alternative to poppy production, but did little to address the problems that had beset its former iteration. ${ }^{70}$

66 Brinkley, "Money Pit: The Monstrous Failure of US Aid to Afghanistan"; Author Interview with Miklaucic; Author Interview with Natsios.

67 Brinkley, "Money Pit: The Monstrous Failure of US Aid to Afghanistan".

68 Senate Caucus on International Narcotics Control, US Counter-Narcotics Strategy in Afghanistan, Washington DC, July 2010, 41; Office of Inspector General, Audit of USAID/Afghanistan's Incentives Driving Economic Alternatives For the North, East, and West Program, USAID, Kabul, June 29, 2012, 2; Committee on Armed Services, Assessment of US Strategy and Operations in Afghanistan and the way ahead, House of Representatives, One Hundred Tenth Congress, Second Session Hearing, January 23, 2008; Committee on Armed Services, Security and Stability, Challenges and Opportunities, 3-4; Assessment of Security and Stability in Afghanistan and Development in US Strategy and Operations, House of Representatives, One Hundred Tenth Congress Hearing, February 13, 2007.

69 Joel Hafvenstein, “Afghanistan's Drug Habit”, New York Times, September 20, 2006.

70 Brinkley, "Money Pit: The Monstrous Failure of US Aid to Afghanistan". 
Other USAID initiatives advocated the manufacture of textiles and oilseeds as a way to improve the economy of Southern Afghanistan, but were unworkable as they violated the Foreign Operations Appropriations Law. Specifically, the Bumpers Amendment prohibited government funding of anything that might compete with US companies in world markets. Through the Amendment, USAID was prevented from assisting Afghanistan to grow a variety of cash crops. In Kunduz, for example, it stopped the agency from implementing a suitable agricultural programme. Rubin acknowledged this to be 'a remarkable example of the failure to align our tools with our strategy'. ${ }^{71}$ The Bumpers Amendment was clearly anathema to USAID's efforts at nation-building in Afghanistan. It was an obscure regulatory instrument of which most officials within the State Department and military establishment were unaware. This ignorance frequently led them to place the blame for project failings at the feet of USAID. If USAID had had more power in Washington, it may have overcome this obscure bureaucratic hurdle. But it did not have meaningful connections in the White House or any significant influence in Congress. Hence the Bumpers Amendment remained a hindrance.

USAID's agricultural projects were also compromised by blurred lines of authority between Washington and Kabul. In 2005, USAID announced 23 agriculture development projects in the Nad Ali District of Kandahar Province. Care and consideration had gone into their planning by USAID officials, who perceived these projects to be a helpful stepping stone to the district's development. Yet these plans never evolved beyond an embryonic form, due to poor communication with civilian officials in Washington, whose interests and priorities did not correlate with that of their colleagues in the field. As the projects were not linked to either counter-narcotics or COIN, they never gained traction in the US capital. ${ }^{72}$

Due to its frustration with the civilian agencies, the military establishment devised the Agribusiness Development Teams (ADTs). ADTs were developed in 2007 as 'an idea to deploy soldiers with agricultural expertise and organic security capabilities to Afghanistan'. ${ }^{73}$ They consisted of US infantry units, such as the Missouri Army National Guard, which was deployed to Afghanistan's Nangarhar province. According to the DoD, the Nangarhar ADT provided 'a complete array of expertise in agriculture, horticulture, pest management hydrology, soil science agricultural processing, and veterinary science' ${ }^{74}$ One would have assumed that the teams included agricultural experts from the United States Department of Agriculture (USDA), development experts from USAID and planners from the State Department. But this was not the case, even though the military argued that

71 Hafvenstein, Opium Season, 145; Committee on Armed Services, Assessment of US Strategy and Operations in Afghanistan and the Way Ahead.

72 Nick Turse, The Case For Withdrawal From Afghanistan (London, Verso, 2010), xlv.

73 Center for Army, Lessons Learned, Agribusiness Teams in Afghanistan: Tactics, Techniques and Procedures (Kansas: United States Combine Arms Center, 2009), 1.

74 Department of Defence, Toward Security and Stability in Afghanistan: Report on Progress, June, $2008,47$. 
ADT projects were undertaken in close coordination with USAID and USDA. ${ }^{75}$ There was no evidence to support that assertion. ${ }^{76}$

Through the ADTs, the military establishment unilaterally pursued another nation-building task to complement its counter-insurgency strategy. Nonetheless, it resented the predicament that a lack of civilian capability had placed it in, as agriculture development projects were alien to its culture. But as the USDA, like USAID, was particularly ill-prepared for development in Afghanistan, the military was compelled to pursue them to augment COIN. A Senior Defence Department Official recalled that the USDA never met its quota of personnel and 'those who they sent really weren't agricultural experts at all in the sense of being farmers'. Rather, 'they were bureaucrats from the foreign agricultural service who knew how to move papers, but they didn't know how to plant anything'. ${ }^{77}$

As a result of this perception, projects were conducted exclusively by soldiers. According to senior military officials, the US National Guard, which took the lead on most ADT projects, brought civilian skills to the table. Civilian officials, however, claimed that the guard was unfamiliar with the theoretical and practical dimensions of Afghanistan's agricultural equation. ${ }^{78}$ Accounts of the activities undertaken by ADTs generally supported the latter group, although the ADT's effectiveness varied dramatically.

ADTs continued to operate in the most conflict-ridden provinces in order to best complement the military's interest in combating the Taliban-led insurgency. As these performed the dual purpose of combat units and agricultural development vessels, there was no place for civilians. Soldiers, like their superiors at the Pentagon, perceived the military to be more experienced than USDA or USAID officials, and believed that they had sufficient expertise to manage the agriculture sector programming without their assistance. The ADT commanders were a higher authority than the civilian officials and, according to USDA officials, overturned decisions made by civilian officials. ${ }^{79}$

Lt Colonel Beckley, who headed one ADT, stated that 'there is no army or air force skill for agriculture', so they looked for soldiers who had farming experience. The Pentagon placed its faith in military reserves who came from farming states like Iowa and Nebraska and were thus more likely to help Afghan farmers improve their crop production. The 'major accomplishment' of Beckley's ADT, however, was the development of a five year agricultural plan, which was hauntingly reminiscent of the Soviet attempts to reform Afghanistan's agricultural system. This simply added to the plethora of ideas on how best to develop Afghanistan's rural environment, while ignoring Afghanistan's traditional land

75 Department of Defence, Toward Security and Stability in Afghanistan, Report on Progress, June, $2009,53$.

76 Bernard Barreua, "Lessons from USDA in Iraq and Afghanistan", PRISM, 1:3 (2010), 139-150.

77 Author Interview with a Senior Defence Department Official, via telephone, Sydney to Colorado, July 15, 2013.

78 This is something that many of the civilian officials interviewed for this study commented on.

79 Barreua, "Lessons from USDA in Iraq and Afghanistan", 146. 
rights and tenure. Beckley admitted that the primary focus of his ADT had become 'government-building', not development. By involving local bureaucrats in the projects, the ADTs pursued the counter-insurgency strategy of winning 'hearts and minds', rather than the most appropriate avenue toward an improvement in Afghanistan's agricultural productivity. ${ }^{80}$

Education did not receive as much attention as road-building and agriculture, but was considered to be the final piece of the developmental triangle by parts of the US government. President Bush was influence by his wife's crusade in Afghanistan for women's rights, so when he spoke of education he was always careful to link this to the empowerment of women. He placed school-building near the top of the US nation-building agenda. Congress, meanwhile, was quick to approve funds for school-building projects, and impatient to see evidence that Afghanistan was progressing from an illiterate backwater to an advanced democratic country. ${ }^{81}$

The Pentagon considered the construction of schools to be a primary indicator of the advancement of Afghanistan's education programme. It also perceived school-building to be an activity that could lure young Afghan males away from joining extremist madrassas in Pakistan. For this reason, David Kilcullen, a senior advisor to General Stanley McChrystal, the Commander of the Combined Forces in Afghanistan from 2009 to 2010, stated that 'local education is critical'. ${ }^{82}$ Schoolbuilding projects undertaken by the military were usually done at the request of favoured Afghan tribal chiefs, and were built quickly and efficiently. USAID officials, however, said that these projects were in violation of the best principles of development practice, and failed to account for factors such as the number of children in Afghan schools, the proportion of girls in the student body, the number of textbooks in the classrooms, and the number of trained teachers being paid and reporting for work. ${ }^{83}$ With these considerations in mind, USAID insisted that school-building proposals were vetted with community groups and linked to building the Afghan Ministry of Education's capacity to staff, equip, and meet the recurrent costs of the education system. But the Pentagon did not share USAID's development philosophy, and dismissed those conditions as needlessly time consuming. Military officials, both in the field and in Washington, branded the agency as 'an incompetent, liberal organization that didn't know what they were doing', ${ }^{84}$

80 Interview with Lieutenant Colonel Beckley, Daily Motion. March 24, 2012. http://www.daily motion.com/video/xpne3d_agribusiness-development-team-commander-interview_news (accessed 13/4/2013).

81 David Wood, "Building Schools in Afghanistan: Not as Simple as ABC", Politics Daily, June 22, 2009 http://www.politicsdaily.com/2009/08/13/building-schools-in-afghanistan-not-as-simple-asa-b-c/ (accessed 12/3/2013).

82 Ibid.

83 Author Interview with a Senior USAID Official, Washington DC, April 19, 2012.

84 Natsios, The Clash of the Counter-Bureaucracy and Development, 17; Author Interview with Andrew Natsios. 
Unfortunately, USAID's record only strengthened these accusations. Despite the call to prioritize education projects from the State Department and the Pentagon, in 2007 USAID devoted only 5 per cent of its budget to improving Afghanistan's education system. As a consequence, of the 286 schools that were planned for refurbishment by the end of 2004, less than half had been completed by 2007 . Problems with school-building projects continued after this. The construction of one school took five years to complete and still had, according to SIGAR, 'a leaking roof, defective electrical wiring, and an improperly sloped terrace roof' ${ }^{85}$

\section{Regulation and Oversight}

Anthony Cordesman, from the Center of Strategic and International Studies, became a spokesperson in Washington for the problem of squandered funds in Afghanistan. In a congressional hearing in 2007, he stated that 'we are spending money without accomplishing things'. 'We have people who are performing symbolic projects at local levels that do not reach the country', Cordesman argued. This amounted to 'showpiece projects in a few isolated areas' rather than 'a campaign or systematic effort'. ${ }^{86}$ The findings of this chapter lend credence to these accusations. Cordesman's admonishment of the US development programme also appealed to the counter-bureaucracy and Congress, albeit for different reasons.

Due to the increased spending that was prompted by the emergence of the Taliban-led insurgency, the Office of Management and Budget (OMB), the Government Accountability Office (GAO), the Office of the Special Inspector General for Afghanistan Reconstruction (SIGAR), and Congress, began to take an active interest in infrastructure development in Afghanistan. Washington's regulatory bodies and various Congressional committees drew the same conclusions: that the US reconstruction effort was wasteful and mismanaged, and that spending for infrastructure projects lacked effective oversight. ${ }^{87}$

The OMB was stringently opposed to any projects that could not produce immediate, noticeable results. It was determined to cut costs, without further deliberation on how this would impact on Afghanistan's development. It endeavoured to limit funds for infrastructure projects and, in 2006, decided that money

85 Barry Bearak, “As War Enters Classrooms, Fear Grips Afghans”, New York Times, July 10, 2007; "US Tax-payers Pour Billions of Dollars Down the Drain in Afghanistan", Washington Times, January 22, 2014, http://www.washingtontimes.com/news/2014/jan/22/WASTE/?page=all (accessed 22/01/2014).

86 Committee on Armed Services, Assessment of Security and Stability in Afghanistan and Development in US Strategy and Operations, House of Representatives, One Hundred Tenth Congress Hearing, February 13, 2007.

87 Michael Thibault and Christopher Shays, At What Cost? Contingency Contracting in Afghanistan and Iraq: Preliminary Findings, Conflict Management, Commission on Wartime Contracting in Afghanistan and Iraq, April 2010, 20-28; Government Accountability Office, Actions Needed to Better Guide Project Selection for Commander's Emergency Response Program and Improve Oversight, Washington DC, June 23, 2008. 
for both roads and electricity did not qualify as emergency aid. ${ }^{88}$ Other bureaucratic barriers, such as the Federal Acquisition Regulation System, aligned with the OMB's culture. Indeed, it appeared that infrastructure projects were diametrically opposed to the appropriations and regulatory process, which reinforced the interests of the OMB at the expense of nation-building in Afghanistan.

The OMB expected US agencies to do more with less. Requests for additional funding by the State Department and USAID were continuously rejected under the rationale that, as Neumann put it, 'the money in the pipeline was sufficient for our needs'. That mentality was espoused by fiscally minded officials at the OMB. Their perception of nation-building was neither based on an accurate assessment of Afghanistan's needs, nor a consideration of the opinions of each agency. Moreover, the OMB did not consult with US officials in Afghanistan before making its decisions. Neumann argues that this circumscribed his ability to implement infrastructure projects. He explained his frustration at the road-block the OMB erected against the State Department's plans:

I argued the urgency of the situation. They replied with explanations of budget procedures. To my mind we were dealing with a war and that ought to demand a different kind of consideration. The answers I received seemed to focus on the rules governing 'normal' economic development. ${ }^{89}$

Neumann encouraged Condoleezza Rice, the Secretary of State, to intervene and approve the funding he requested, but she ignored his advice. ${ }^{90}$ Rice, it seemed, was beholden to the OMB, rather than the State Department's foremost representative in Afghanistan. Furthermore, a lack of effective communication between Kabul and Washington combined with competing spheres of authority within the State Department, and conflict between it and USAID, to strengthen the more united, and thus powerful, OMB's hold over funding for infrastructure projects in Afghanistan.

The OMB also encroached on the military establishment's infrastructure development programme. A Pentagon Official dismissed the GAO and SIGAR, but he claims that the OMB proved to be a significant road-block for funding: 'The OMB was the not just $a$ problem, but the problem', he contended..$^{91}$ Despite the fact that the CERP program had become what one US auditor describes as a 'sacred cow' in Washington, the OMB criticized it and other Pentagon-driven infrastructure development projects. ${ }^{92}$

88 An interview with Richard Armitage, PRISM, 1:1, 107.

89 Neumann, The Other War: Winning and Losing Afghanistan.

90 Ibid.

91 Author Interview with a Senior Defence Department Official, via telephone, Sydney to Colorado, July 15, 2013.

92 Dana Hedgpeth and Sarah Cohen, "Money as a Weapon”, Washington Post, August 11, 2008. http:/www.washingtonpost.com/wp-dyn/content/story/2008/08/10/ST2008081002653.html (accessed 3/2/2013). 
Although the various agencies in Afghanistan failed to agree on most issues, they were all equally resentful of the OMB's attitude toward infrastructure development. Officials at the State Department, USAID and the Pentagon were united in their hostility toward the OMB, which created unnecessary road blocks and made it difficult to move ahead with all kinds of operations. A Senior Defence Department Official recalls that it 'became an independent power centre that withheld reconstruction funds for reasons many of us still don't understand' ${ }^{93}$

Much like the OMB, the GAO and SIGAR judged US agencies on how fast and efficiently they spent money and produced results, rather than the long-term benefits the reconstruction projects may have had. ${ }^{94}$ They highlighted staff shortages and inconsistent financing to determine that US infrastructure development projects suffered from a lack of oversight. Neither of them possessed the power of the OMB, but they were still able to pressure US agencies by taking their findings to Congressional Committees. SIGAR's anti-corruption initiative, for example, which was launched in 2010, focused primarily on assessing the US government's funds and their effective use. Backed by Congress, it pressured US agencies to allocate money immediately to prove that it was engaging efficiently in reconstruction..$^{95}$

There were similar examples of this behaviour from the GAO. Multiple reports by the Government Accountability Office criticized the lack of monitoring and oversight by the military establishment. In July 2004, the GAO argued that the Pentagon did not have an adequate number of personnel to supervise its infrastructure development projects. Two years later, it highlighted the same problem and stated that without a sufficient number of oversight personnel the DoD could not monitor its contractors. Subsequent reports argued that the monitoring of military projects stopped once they had been completed, complaining that the military establishment was not interested in how such projects were maintained. ${ }^{96}$

The DoD Contracting Officer's Representatives (COR) were, 'responsible for insuring that contractors meet the requirements set forth in the contract'. But the GAO discovered that only a small number of them had any background in contracting or oversight, and that all of them were under-trained, but overworked. Most CORs, moreover, could only oversee contracts in their spare time as the

93 Author Interview with a Senior Defence Department Official, via telephone, Sydney to Colorado, July 15, 2013.

94 Author Interview with a Senior USAID Official, Washington DC, April 19, 2012.

95 Commission on Wartime Contracting, An Urgent Need: Coordinating Reconstruction and Stabilization in Contingency Operations, 2010, 6.

96 Government Accountability Office, Afghanistan Reconstruction: Progress Made in Constructing Roads but Assessments for Determining Impact and a Suitable Maintenance Program Are Needed, Report to Congressional Committees, July, 2008; Government Accountability Office, Military Operations: DOD's Extensive Use of Logistics Support Contracts Requires Strengthened Oversight, Washington, DC, July, 2004; Government Accountability Office, Military Operations: High-Level DOD Action Needed to Address Long-standing Problems with Management and Oversight of Contractors Supporting Deployed Forces, Washington, DC, December 18, 2006. 
other duties they performed for the military were perceived to be more important. In response to the GAO's criticism, the Pentagon simply stated that it did not have the information to provide an answer. CERP guidelines were reviewed and revised in December 2009, but there was still no requirement for US troops to inspect projects once they had been transferred to Afghan control. ${ }^{97}$

Although the GAO and SIGAR's analysis of the situation in Afghanistan was more detailed, sophisticated and credible that the OMB's, therefore, they had less power to influence the behaviour of US agencies - especially the military establishment. In the opinion of officials from USAID, the State Department and the military establishment, the methods chosen for assessment by the GAO and SIGAR were naïve and inappropriate. The GAO and SIGAR, they argued, warped many programmes so that money was thrown about haphazardly to produce statistics that would placate the counter-bureaucracy and its allies in Congress. ${ }^{98}$

\section{Congress}

As the previous section suggests, the interests of some elements in Congress mirrored those of the counter-bureaucracy, while others propounded unique development initiatives. The interests of most congressmen and women in infrastructure projects were centred on Afghanistan's drug problem, the Taliban-led insurgency, or both. Curbing illicit crop production was perceived to be an urgent priority, and the US House of Representatives voted to implement a pilot programme 'regardless of the level of success'. Congress also latched on to initiatives that had been successful elsewhere in the world, such as the Roots of Peace project, which took out landmines and replaced them with trees, an idea that one State Department official dismissed as little more than a flight of fancy. ${ }^{99}$

Duncan Hunter, a member of the Committee on Armed Services, railed against the programmes of US agencies, instead suggesting 'substituting orchards for poppies', and 'tough old practical farmers' in order to 'replace a legion of our bureaucracy personnel'. ${ }^{100}$ Orchards, in principle, seemed like a viable suggestion. US government agencies in the field, however, were aware that the idea was an oversimplification of a complex and difficult problem, and that such strategies were unsuited to the barren environment that characterized Afghanistan's southern poppy-ridden provinces. Hunter's perception that such a programme could work in an arid environment seemed viable from his seat at Congress in the US

97 Brinkley, "Money Pit: The Monstrous Failure of US Aid to Afghanistan"; Boak, "US Funded Infrastructure Deteriorates Once Under Afghan Control, Report Says".

98 That opinion was repeated time and time again in the interviews with US officials from State, USAID and the DoD that were conducted by the author.

99 United States Congress Afghanistan Freedom and Security Support Act of 2007, Report 110-170, Section 104, Subsection B, 2007-2009; Committee on Armed Services, Assessment of Security and Stability in Afghanistan and Development in US Challenges and Opportunities, 23.

100 Ibid., 3. 
Capital, but would undoubtedly have changed had he experienced the political, security and ecological conditions in those provinces firsthand.

In other areas of infrastructure development, Richard Armitage, the Deputy Secretary of State from 2001 to 2005, lamented Congress's want of 'feel good' items that proved that the US was engaged in development, such as medical clinics and schools. He contrasted this sharply with the legislative branch's aversion to less glamorous infrastructure development programmes, such as sewerage plants and electricity grids, and highlighted the difficulty that the State Department faced in Afghanistan when trying to balance practical solutions with congressional musings. ${ }^{101}$ This was a valid point but, as we have discovered, the State Department and the military establishment were also guilty of promoting their interests to prioritize road-building, agriculture and education over less desirable infrastructure projects.

\section{Conclusion}

Different interests, cultures, perceptions and power between and within agencies determined that for the United States, a united, inter-agency approach to infrastructure development was never realized. The military establishment, with its vast resources, influence and manpower, dismissed the civilian branches as impotent and unqualified. Instead of supplementing their efforts, it approached reconstruction unilaterally and contrived to adapt its culture to incorporate a developmental mandate. The US military conducted combat missions with clarity and cohesion, but such uniformity was not so easily transferred to its infrastructure development programme.

The civilian agencies, meanwhile, resented the military's domineering approach to reconstruction. USAID, especially, considered its tactics to be inappropriate and unfeasible. USAID's approach to development, however, was no better for nation-building. Within the foreign policy bureaucracy the agency remained a minnow, but the prominence of its activities in Afghanistan drew the attention of the State Department and the military establishment. USAID thus faced a dilemma: it could adhere to its cultural traditions and pursue a distinctive development strategy, or it could adjust its approach to reflect the interests of the State Department, the military establishment, or both. This chapter has demonstrated that although USAID sometimes asserted its independence, more often than not it demurred and accepted the preferences of the more powerful bureaucratic forces. But regardless, USAID's lack of capacity meant that it was incapable of conducting the quick-impact projects that the State Department, the military and other factions in Washington desired. This combined with the agency's inability to control or monitor its contractors, which further tarnished its reputation in the eyes of other branches of government. Even its attempts to pursue the small-scale long-term projects that it was more accustomed to, were plagued by mistakes and 
poor judgement, and the agency was criticized just as much for this as it was for its other failures.

The machinations of the foreign policy bureaucracy prevented the US from constructing a sustainable road network, an economically beneficial agricultural programme or an effective education system. Other, arguably more suitable areas of development, such as sewerage and electricity, remained a less attractive prospect. Although the agencies tasked with reconstruction were uncoordinated and disorganized, they coalesced to resist the encroachment of the OMB. An ignorance of the situation in Afghanistan did nothing to temper the OMB's determination to intervene in the US development programme, which added another strand to an already complicated web of competing bureaucratic factions. The GAO and SIGAR, meanwhile, proved to be more of an irritation than a hindrance to the other agencies. Despite rhetorical platitudes to the contrary, they endeavoured to ignore the GAO and SIGAR's recommendations, even when it was obvious that they may have improved the US approach to infrastructure development. The interests of Congress, meanwhile, were mercurial; at times it sided with the counter-bureaucracy, at other times it reinforced policies that prioritized roadbuilding and agriculture. It also put forward its own divergent initiates. Given all this, it is little wonder that nation-building in Afghanistan encountered the problems that it did. 


\section{Counter-Narcotics, Law and Governance*}

Counter-narcotics, law and governance constitute the final three nation-building issues examined in this book. These are all related and interconnected, but the US generally approached them separately and haphazardly, with damaging consequences. Of particular concern for US government officials was the heroin trade. After 2001, Afghanistan regained its former position as the world's largest global supplier of heroin. Funds from the sale of heroin were used to bolster the position of autocratic figures, drug barons and, by some accounts, the Taliban-led insurgency. ${ }^{1}$

While Afghanistan's drug trade thrived, the country's legal system was stillborn. In 2007, according to the World Bank, Afghanistan ranked in the top 99.5 per cent of ineffective and corrupt justice systems worldwide, and ranked 172 out of 179 countries on Transparency International's Corruption Index. ${ }^{2}$ Mechanisms to promote democratic government fared little better. Elections were characterized by violence, corruption and intimidation, and were unreflective of the will of the people at both the local and national level. The 2004 Afghan Constitution, moreover, was a vague document that formally empowered the President, while being ignored by Afghanistan's ubiquitous tribal rulers and religious authorities beyond Kabul. ${ }^{3}$ The Karzai government did little to ingratiate itself with the Afghan people. Karzai himself, although charismatic, was perceived to be incompetent and dishonest. ${ }^{4}$

* Some sections of Chapter 7 appeared in "Divided We Stand: The US Foreign Policy Bureaucracy and Nation-Building in Afghanistan”, International Peacekeeping 22:3 2015, pp. 205-229. Reprinted by permission of Taylor and Francis group - http://tandf.co.uk. Parts of the Chapter are also utilized in a forthcoming (as of 2016) article in Foreign Policy Analysis, titled 'The impact of bureaucratic conflict on US counter-narcotics efforts in Afghanistan.

1 Fariba Nawa, Opium Nation: Child Brides, Drug Lords, and One Woman's Journey through Afghanistan (New York: Harper, 2011), 149-168. Eric Schmitt, "Many Sources Feed Taliban's War Chest", New York Times, October 18, 2009.

2 World Bank, Governance Matters 2007: Worldwide Governance Indicators, 1996-2006 (Washington DC: World Bank, 2007); Transparency International, Corruption Perceptions Index (Berlin: Transparency International, 2007).

3 James Ingalls, "The New Afghan Constitution: A Step Backwards for Democracy", Foreign Policy in Focus, March 13, 2004, 1-32.

4 Jon Boone, "WikiLeaks Cable Portrays Karzai as Corrupt and Erratic", The Guardian, December 3, 2010; Robert Blackwell, "Plan B in Afghanistan: Why De Facto Partition is the Least Bad Option", 
This chapter reveals the impact that US policy and bureaucratic politics had on enabling such circumstances. First, it examines the US's approach to combating Afghanistan's drug trade (counter-narcotics), which centred on eradication and interdiction. Second, it assesses US efforts to construct Afghanistan's legal system. Finally, there is a discussion of the vexed issue of democracy promotion in Afghanistan, which includes US attempts to facilitate a centralized model of national governance.

\section{Counter-Narcotics Programme}

Narcotics have been a significant presence in Afghanistan since the 1500s. ${ }^{5}$ Insecurity, favourable geography, poor economic circumstances and a weak state combined to facilitate a lucrative drug trade. ${ }^{6}$ The cultivation of opium poppy proliferated when the Soviet Union ravaged the Afghan countryside during the 1980s, destroying crops and irrigation channels in an attempt to force the rural population into urban centres, in order to expose and defeat the Mujahedeen-led insurgency. This tactic, coupled with the Soviets' ill-conceived land-reforms, crippled Afghanistan's agricultural infrastructure. A tough and drought-resistant crop, opium poppy became a popular alternative to licit farming. Afghanistan's porous borders also made it easy for narcotics traffickers to move their product, and for drug syndicates to develop a lasting presence in the country. Under the Taliban, Afghanistan became the world's largest opium producer, until it banned poppy farming in 2001 . $^{7}$

In 2002, despite a ban on the cultivation and trade of opium from the nascent Karzai government, the opium trade expanded exponentially. Poppy production involved vast networks, which stretched from the individual farmer to the upper echelons of government. Warlords, corrupt government officials, tribal authority figures and drug barons established a 'thriving criminal layer' which coerced the rural population to grow, store and process drugs. Often, however, farmers did not need to be forced to grow poppy. Without desirable agricultural alternatives they coveted the lucrative profits poppy farming ensured. On a more basic level, as a majority of the population lived below the poverty line, opium poppy provided a stable and reliable source of income. ${ }^{8}$

The scale of Afghanistan's drug problem in the twenty-first century is wellknown: "no other country had such a dominant position in the global supply of

Foreign Affairs, 90 (20110, 43. Mills, Karzai: The Failing American Intervention and the Struggle for Afghanistan.

5 David MacDonald, Drugs in Afghanistan: Opium, Outlaws and Scorpion Tales (London: Pluto Press, 2007), 137.

6 Jonathan Goodhand, "Corrupting or Consolidating the Peace? The Drugs Economy and Postconflict Peace-building in Afghanistan", International Peacekeeping, 15:3 (2008), 408.

7 William Maley, The Foreign Policy of the Taliban (New York: Council on Foreign Relations, 2000).

8 Tariq Ali, "Mirage of a Good War", in Nick Turse (ed.), The Case for Withdrawal from Afghanistan (London: Verso, 2010), 54; United Nations Office on Drugs and Crime (UNODC), Afghanistan Farmer's Intentions Survey 2003/2004, February, 2004, 5; UNODC, World Drug Report, June, 2005; Vanda Felbab-Brown, "Afghanistan: When Counternarcotics Undermines Counterterrorism”, Washington Quarterly, 28:4 (2005), 57. 
Opiates'. ${ }^{9}$ The export of opium surpassed 8,000 tons in 2006, with a value of $\$ 3.1$ billion. Opium poppy directly provided income for more than 2.3 million Afghans, with a third of the population employed in some part of the drug industry. By 2010, Afghanistan produced over 90 per cent of the world's heroin, and the drug trade pumped $\$ 2.8$ billion dollars into its economy, which equated to more than 30 per cent of GDP. ${ }^{10}$

How had this occurred under the auspices of the US-led nation-building mission? To be sure, the drug trade was an entrenched feature of the Afghan environment prior to the arrival of US and NATO troops. As such, it was perhaps beyond the capacity of any external force to completely repress. The Afghan State's attempts to address the problem were lacklustre. The Karzai government's counter-narcotics strategy has been heavily criticized, and corrupt government officials were often a conduit for the drug trade. The Afghan National Police, furthermore, did not have the capacity to win the 'war on drugs', because it suffered from corruption and drug addiction that were exacerbated by the ineffective US training programme. The United Nations Office on Drugs and Crime Task Force lacked sufficient resources to implement comprehensive prevention mechanisms. Countries within the NATO alliance, as well as other parties such as Russia, also failed to undertake a coordinated approach. The British, who were placed in charge of counter-narcotics as a result of the Bonn Process, had neither the expertise nor the influence to successfully spearhead the international response, and their eradication and buy-back strategies were an abject failure. ${ }^{11}$

The United States, however, must also share a portion of the blame for Afghanistan's drug problem, due to its inappropriate and defective counter-narcotics strategy. Three US agencies were involved in counter-narcotics: the military establishment, the State Department and the Justice Department. Additionally, two organs within State and Justice, the Bureau of International Narcotics and Law Enforcement Affairs (INL) and the Drug Enforcement Administration (DEA), functioned as relatively independent power centres. Each of these factions had a different perception of how to approach Afghanistan's drug problem, which was somewhat dictated by their area of interest and their culture. Additionally, the perceptions of certain officials within the US bureaucracy muddied the waters of US counter-narcotics policy.

Unfortunately, the military establishment did not react to the revival of opium production immediately after the fall of the Taliban, at a time 'when the target

9 Goodhand, "Corrupting or Consolidating the Peace?"

10 UNODC, Afghanistan Opium Survey 2004; UNODC, Afghanistan Farmer's Intentions Survey 2003/2004, 5; Carlotta Gall, "Opium Harvest at Record Level in Afghanistan”, New York Times, May 24, 2006.

11 Darryl Arfsten et al., "Drug use Among the Afghan National Police: A National Assessment", Military Medicine, 177:1, 2012, 85-90; Committee on Armed Services, Assessment of US Strategy and Operations in Afghanistan and the Way Ahead, House Of Representatives, One Hundred Tenth Congress, Second Session Hearing, January 23, 2008, 12; Felbab-Brown, "Afghanistan: When Counternarcotics Undermines Counterterrorism", 61. 
was small and the signal sent would have been effective'. ${ }^{12}$ Doug Feith, the Under Secretary of Defence from 2001 to 2005, contended that Afghanistan's opium production was not a serious concern for the United States. Rumsfeld had informed his senior staff that the drug issue was an unwelcome distraction from capturing the remnants of Al Qaeda's leadership. Even as the Taliban-led insurgency worsened, the Pentagon dismissed the idea of military involvement in drug prevention, as it feared that this would compromise its war-fighting mission. ${ }^{13}$

In the field, US commanders such as Karl Eikenberry, the Commander of the Combined Forces from 2005 to 2007, made no attempt to mobilize the military for counter-narcotics, nor did he aid the civilian agencies in their efforts. As one senior official observed, 'Eikenberry was adamant that the (military) command didn't do counter-narcotics, so it died away'. ${ }^{14}$ An insider contends that much the same mentality afflicted senior Defence Department officials:

When I was there, the military were not particularly prominent in drug prevention. We weren't particularly effective, [and] the Defence Department had no idea what the Department of Justice, the Department of State or USAID were doing. ${ }^{15}$

Part of the reason behind the military establishment's reluctance to engage in counter-narcotics was that it believed that such activities compromised its interests, which centred on combat operations. The Pentagon assumed that a forceful counter-narcotics drive would alienate potential informants, many of whom were embroiled in the opium trade, but who also provided credible intelligence on the Taliban and Al Qaeda. Indeed, military officials often met with individuals who were known as the godfathers of drug-trafficking. As Risen observes, 'for Afghanistan's drug lords, business was very good under the United States Central Command'. ${ }^{16}$ In addition, the military establishment argued that counternarcotics would compromise the safety of US soldiers. In Jalalabad, for example, a strongman named Hazrat Ali sheltered US troops in his area of control, 'under the understanding that they left his drug business intact'. ${ }^{17}$

As the opium trade escalated during the second term of the Bush Administration, however, voices within the US government called for immediate, comprehensive prevention measures. By 2007, drugs had become an important issue for both Congress and the media. This prompted Defence Secretary Robert Gates to acknowledge that 'the drug trade continues to threaten the foundations of Afghan

12 Maley, The Afghanistan Wars, 249.

13 James Risen, State of War: The Secret History of the CIA and the Bush Administration (New York: Free Press, 2006), 157-158.

14 Yodsampa, No-one in Charge, 203.

15 Author Interview with a Senior Defence Department Official, via telephone, Sydney to Colorado, July 15, 2013.

16 Risen, State of War, 154-56 and 162.

17 Felbab-Brown, "Afghanistan: When Counternarcotics Undermines Counterterrorism", 65. 
society and [the] young government [of Afghanistan]'. ${ }^{18}$ General James Jones, the Commander of the United States European Command, claimed that the drug trade was extremely harmful to nation-building and worried that Afghanistan was on the brink of becoming a narco-state. In 2008, General David Petraeus, the Commander of the United States Central Command, described drug money as 'the oxygen in the air' that helped the Taliban-led insurgency to prosper. ${ }^{19}$ Notwithstanding this rhetoric, no action was initially taken by the military, which prompted Richard Holbrooke, the US Special Envoy for Afghanistan and Pakistan from 2009 to 2010, to criticize the 'strict limits' imposed by the Pentagon on a US drug-prevention role. Without a change in US policy, he warned, Afghanistan would be held to ransom by its rampant drug barons. ${ }^{20}$ But the Pentagon assumed a commitment to counter-narcotics would inculcate "mission creep" and compromise COIN and thus remained opposed to the commitment of any significant military resources toward the endeavour. A Congressional Committee report revealed that even by 2010 , 'the correlation between the war effort and counternarcotics effort was not fully recognized'. ${ }^{21}$

The State Department was more concerned than the military with the threat that opium poppy production presented. It was attuned to the opinions of Western Europe, Russia and the United Nations, who worried about the impact that Afghanistan's poppy production would have on Europe's heroin trade. From 2003, US officials at the Embassy in Kabul and in Washington viewed opium production as a nation-building issue, which required a comprehensive and far-reaching solution. This perspective gained momentum as Afghanistan's drug trade increased. Thomas Schweich, the Coordinator for Counter-narcotics and Justice Reform in Afghanistan, averred that 'it's all related . . . It's no longer just a drug problem. It is an economic problem, a political problem and a security problem' ${ }^{22}$ According to a 2006 State Department report to Congress, 'Afghanistan's huge drug trade severely impacts efforts to rebuild the economy, [and] develop a strong democratic government based on the rule of law'. ${ }^{23} \mathrm{~A}$ DoD official stated that whereas the US military was not interested in the broader implications of the drug trade, the State Department 'pushed hard for a comprehensive counter-narcotics plan'. ${ }^{24}$

The INL proved to be the most active faction within the State Department. In 2002, a prescient report conducted by the Bureau argued that there was 'virtually

18 Department of Defence, Report on Progress Toward Security and Stability in Afghanistan, June, $2008,6$.

19 General David Petraeus, Commander of US Central Command, Testimony, before the Senate Armed Service Committee, March 16, 2010.

20 McCoy, The Politics of Heroin, 523.

21 Senate Caucus on International Narcotics Control, US Counter-Narcotics Strategy in Afghanistan, Washington DC, July 2010, 20.

22 James Risen, "Poppy Fields are now a Front Line in Afghan War", New York Times, May 16, 2007.

23 Judy Dempsey, "General Calls Drugs Biggest Test for Afghans", International Herald Tribune, May 22, 2006.

24 Yodsampa, No-one in Charge 138. 
no counter-narcotics enforcement in Afghanistan', predicting that 'the drug trade will continue to flourish in the absence of concerted enforcement efforts'. ${ }^{25}$ When it came to counter-narcotics, the INL considered itself the most powerful and experienced agency within the US government. With this in mind, it believed that the remainder of the government should not only support its actions, but should also follow its lead. One US Military Commander says this left little room for amiable collaboration with other agencies: 'The military had some pretty bright lines that we couldn't go too far into that particular arena as it was viewed as an INL mission', he recalls. ${ }^{26}$ It was not until 2010 that the INL finally realized that the narcotics trade required an inter-agency strategy.

The Justice Department's Drug Enforcement Administration (DEA) was another faction that considered counter-narcotics in Afghanistan to fit within its range of interests, which were 'to disrupt and dismantle the most significant drug trafficking organizations posing the greatest threat to the United States'. ${ }^{27}$ From 2004, the DEA had small teams embedded in US military bases, but became frustrated when the security situation in many provinces prevented such teams from fulfilling their mandate. Much like the State Department, the DEA promoted a comprehensive programme that included tracking narcotics activity, training counter-narcotics police, and deploying teams that conducted counter-narcotics operations to destroy opium crops and processing labs. ${ }^{28}$ To successfully pursue these activities, it advocated involvement on the part of the military establishment. For Doug Wankel, the DEA's Chief of Operations in Afghanistan, combating Afghanistan's drug problem required the coordination of counter-narcotics and counter-insurgency to provide a suitable and sustainable long-term solution. The DEA nonetheless operated with relative autonomy from other government agencies, and did not actively seek to foster a whole-of-government strategy. ${ }^{29}$

In much the same fashion as the INL, the DEA's culture meant that it portrayed itself as the US government's flagship agency for counter-narcotics. It wished to define the US strategy in Afghanistan, rather than act as a component within a broader effort. ${ }^{30}$ While the INL may have marked counter-narcotics as its turf, the DEA did not acknowledge that claim. Its Drug Flow Attack Strategy and Special Operation Division were independent programmes and they essentially cloned previous drug strategies in Mexico and Columbia. However, because those

25 Department of State, Bureau for International Narcotics and Law Enforcement Affairs, International Narcotics Control Strategy Report - 2001 Southwest Asia, Washington DC, 2002, 4.

26 Author Interview with a Senior US Military Commander, Washington DC, April 29, 2012.

27 Statement of James Capra, Chief of Operations, Drug Enforcement Administration, Caucus on International Narcotics Control, "Future US Counter-Narcotics Efforts in Afghanistan", United States Senate Hearing, January 15, 2014, 1.

28 Ali Jalali, Robert Oakley and Zoe Hunter, Combating Opium in Afghanistan, Institute for National Strategic Studies, National Defence University, November 2006, 3; John Glaze, Opium in Afghanistan: Reassessing US Counter-Narcotics Strategy, Strategic Studies Institute, October 2007, 9.

29 Author Interview with a Senior State Department Official, Washington DC, April 18, 2012.

30 Capra, "Future US Counter-Narcotics Efforts in Afghanistan". 
programmes relied on the resources of the military establishment, it proved difficult for them to have a substantial impact.

Influential voices in Congress, meanwhile, claimed that 'the success of the military effort in Afghanistan depends on the success of the counter-narcotics strategy'. ${ }^{31}$ These same voices identified the Taliban as the world's most eminent and dangerous drug cartel, even though this judgment went against the opinion of most experts, who claimed that the connection was 'rather murky' ${ }^{32}$ Indeed, the UNODC estimated that of the $\$ 3$ billion generated by Afghanistan's drug industry in 2010 , only $\$ 90-160$ million was used to support the insurgency. ${ }^{33}$

Instead of promoting clarity, Congressional interest only complicated the matter of how to pursue a strategy against drugs in Afghanistan. Prominent congressmen criticized the US government's inability to coordinate a comprehensive plan to tackle the drug problem through 'practical initiatives to target major drug kingpins and warlords' ${ }^{34}$ In the wake of a Congressional search for tangible results which had been supported by many State and DoD officials in Washington long-term solutions advocated by those in the field were ignored. A former US Ambassador to Afghanistan viewed Congressional pressure as a significant problem, which spurred a quick-fix solution where, 'you get this screaming pressure that something must be done about this and you have to solve the problem now'. ${ }^{35}$ Yet there was no concerted effort to get to the heart of the drug issue by targeting traffickers and the corrupt officials they were associated with, nor was there a chain linking the drug problem to education, security, law and development.

Clearly, the US approach to counter-narcotics was complex and disorganized. But an overarching programme did emerge in 2005. It revolved around five main elements: judicial reform, public awareness campaigns, poppy eradication, drug interdiction and agricultural development. On initial impressions this 'pillared approach' embraced a comprehensive, multilayered strategy. But this proved to be an illusion: 'The failure had been in implementation rather than conceptualization', Neumann states. ${ }^{36}$ Only in 2007 did an inter-agency plan for counterinsurgency and counter-narcotics become manifest. However engagement through bodies such as the Eradication Working Group, Counter-Narcotics Sync Group in Kabul, and Interagency Counter-narcotics Working Group in Washington, did not overcome the entrenched problems of agency culture and interests: 'When we

31 Senate Caucus on International Narcotics Control, US Counter-Narcotics Strategy in Afghanistan, 5.

32 Felbab-Brown, “Afghanistan: When Counternarcotics Undermines Counterterrorism”, 59.

33 Government Accountability Office, Afghanistan Drug Control: Strategy Evolving and Progress Reported, but Interim Performance Targets and Evaluation of Justice Reform Efforts Needed, Washington D.C., March 2010, 3.

34 Congresswoman Ileana Ros-Lehtinen of Florida, Sheryl Stolberg, "Pressing Allies, President Warns of Afghan Battle", New York Times, February 16, 2007.

35 Author Interview with a Senior State Department Official, Washington DC, April 18, 2012.

36 Neumann, The Other War: Winning and Losing Afghanistan. 
started developing this interagency plan, everybody knew the narcotics numbers would be bad' a sceptical Pentagon official groused. ${ }^{37}$

There was no move by the US government to conduct drug demand reduction programmes that targeted the ANP. Neither the State Department nor the military establishment had attempted to cooperate toward that end. When the GAO urged the two agencies to do so, the Department of Defence rejected this suggestion. 'The scope of mission does not include branching into drug rehabilitation programmes, nor do we believe that we have the expertise in DoD to take on such an additional mission', Michael Vickers the Assistant Secretary for Defence claimed in 2010. The DoD instead requested that the civilian agencies take responsibility for such a programme. Although the State Department was more willing to pay the idea lip-service, its posture was practically identical to the military's. ${ }^{38}$

Given the reluctance of the DoD and the State Department to cooperate on a whole-of-government approach to counter-narcotics, it is little wonder that the blunt instruments of eradication and interdiction remained the most important pillars of the US's counter-narcotics strategy. From 2005 to 2010, the US spent a total of $\$ 2,504$ million on counter-narcotics. Of this money, $\$ 992$ million was spent on eradication and $\$ 966$ million on interdiction, thereby eclipsing all other areas of counter-narcotics prevention.

Eradication was the more controversial of the two strategies. Afghans across the country complained of its pernicious impact on their livestock and health. Studies also found that by decreasing supply relative to demand, eradication functioned as 'a price- support program that benefits traders'. Both Goodhand and Felbab-Brown described eradication in Afghanistan as counter-productive because it targeted farmers and undermined the capacity of the State vis-à-vis strongmen, warlords and the Taliban. Eradication, for these two critics was a myopic solution to a complicated problem. ${ }^{39}$

Within the US government, heated debate arose as to whether eradication was appropriate or effective. Civilian officials in the field, who had experienced Afghanistan's political and environmental nuances, were less inclined to support the strategy. Many at the US Embassy in Kabul were convinced that eradication fuelled Taliban propaganda and destroyed food crops. Even if one were to ignore these harmful effects, some officials made the more basic point that all evidence suggested that eradication simply did not work. Ambassador Neumann, for

37 New York Times, "Pentagon Sees Aggressive Antidrug Effort in Afghanistan”, March 25, 2005.

38 Michael Vickers, Assistant Secretary of Defence, Appendix III: Comments from the Department of Defence in Afghanistan Drug Control: Strategy Evolving and Progress Reported, but Interim Performance Targets and Evaluation of Justice Reform Efforts Needed, Government Accountability Office, Washington DC, March 2010, 47.

39 Carlotta Gall, "Afghans Accuse US of Secret Spraying to Kill Poppies", New York Times, February 27, 2005; Goodhand, "Corrupting or Consolidating the Peace? The Drugs Economy and Post-conflict Peace-building in Afghanistan", 408-417. Felbab-Brown, "Afghanistan: When Counternarcotics Undermines Counterterrorism”, 61. 
example, described it as 'like trying to fill up a bucket by spitting in it, it was just not going to inherently produce results people wanted'. He wrote a cable opposing the eradication and argued that it 'will make narcotics worse ... and make the Taliban's role easier'. Similarly, once DEA officials gained an understanding of the situation in Afghanistan their perception changed. Afghan drug traffickers, they realized, collaborated with the population often to the benefit of the latter: 'They'll share land. They'll share labs and chemists. It was surprising to those of us who came from areas where that was a problem', one DEA official remarked. ${ }^{40}$

The INL, meanwhile, favoured the more tangible results that eradication promised. Bobby Charles, the Associate Secretary of State for International Narcotics and Law enforcement, believed that the US had the ability to destroy much of Afghanistan's opium production capacity if it focused on eradication. Charles's perceptions and opinions were shaped by his agency's culture. For him, the DEA's experiences in Mexico and Colombia showed that 'you can't win against terrorism funded by an indigenous drug trade' and that 'heroin was the fuel running the engine of Taliban terrorism'. ${ }^{41}$ The INL was supported by some members of Congress and a number of White House officials, who perceived the use of herbicide to be critical to the prevention of poppy production. As these powerful forces coalesced, eradication became a central component of the State Department's interests in Afghanistan.

Following the departure of Colin Powell the INL faced a power struggle with his replacement as Secretary of State, Condoleezza Rice, who openly challenged the Bureau on the importance of eradication. In response to this encroachment, Charles, who spearheaded the State Department's eradication strategy, moved outside of his department and exhorted Congress to intervene. In his opinion, the INL needed to have an even stronger mandate to head a comprehensive eradication campaign, which required further Congressional support. A turf-conscious State Department, however, took issue with this apparently seditious approach and this forced his resignation. Even without Charles, the INL and its supporters continued to fund eradication initiatives based upon the agency's previous experience with cartels in Colombia and Southeast Asia. But when applied to Afghanistan, these programmes targeted poor farmers, rather than the drug barons and actually drove many farmers to support the Taliban.

The INL also had a powerful supporter in Kabul. William Wood, Ambassador to Afghanistan from 2007 to 2009, was unpopular outside the INL due to his interest in poppy eradication. Wood relied on the INL, which drew the ire of other factions within the State Department, and the military. The new Secretary of Defence, Robert Gates, concluded that 'spraying is not a long-term strategy'.

40 Neumann, The Other War: Winning and Losing Afghanistan; Ernesto Londoño, "As US Withdraws from Afghanistan, Poppy Trade it Spent Billions Fighting Still Flourishes", Washington Post, November 13, 2013.

41 Dane Smith. US Peacefare: Organizing American Peace-Building Operations (Washington DC: Center for Strategic and International Studies, 2010), 80-81. 
Instead, Gates advocated two plans. The first of these provided Afghan farmers with alternatives to poppy production, which was embodied in the Alternative Livelihoods Program (ALP), and the second centred on preventing corruption, in partnership with the Department of Justice. Spraying in Colombia failed to diminish the flow of drugs there, he argued. ${ }^{42}$ Ambassador Wood saw it differently. He was heavily influenced by his previous experience as Ambassador to Columbia, where he had been exposed to the INL's unique culture. According to a surprised United States Embassy official in Kabul, he even offered to bathe in the chemicals used for spraying in order to prove their safety. This resulted in his staff adopting the moniker 'Chemical Bill' to describe their superior. ${ }^{43}$

Wood circumvented normal State Department channels and employed private contractors such as AmorGroup to undertake eradication missions. He also avoided collaboration with the DEA. The latter claimed that Wood's stance undermined inter-governmental programmes that mentored specialist ANP units and trained Afghan lawyers and judges in prosecuting narcotics cases - both of which had shown tentative progress. Finally, notwithstanding some minor exceptions, the military establishment believed that Wood's eradication plan deeply alienated rural Afghans who depended on poppy production for their families' subsistence. The US Ambassador nonetheless stepped up his campaign, even as the military distanced itself from destroying poppy crops. ${ }^{44}$

When Richard Holbrooke became aware of this he acted on the matter. A diplomat of the more traditional mould, he did not perceive eradication to be an appropriate solution to Afghanistan's drug problem. In 2009, the Special Envoy to Afghanistan and Pakistan campaigned against eradication: 'Eradication is a waste of money', he argued, 'it might destroy some acreage, but it didn't reduce the amount of money the Taliban got by one dollar. It just helped the Taliban. So we're going to phase out eradication' ${ }^{45}$ Holbrooke's influence would subsequently help to redirect counter-narcotics more toward interdiction and the ALP. But despite his powerful position, eradication continued to be a feature of State Department policy. In $2009, \$ 237$ million was spent on eradication, considerably more than the previous three years. In 2010, the INL sustained a Poppy Eradication Force that consisted of over 600 ANP officers. ${ }^{46}$ The matter of eradication, therefore, was yet another illustration of parochial divisions within the State Department, deepened by factional interests, cultural predispositions and personal experience.

42 Jim Hoagland, "Poppies vs Power in Afghanistan", Washington Post, December 23, 2007.

43 Kirk Semple and Tim Golden, “Afghans Pressured By US on Plan to Spray Poppies', New York Times, October 8, 2007. Allisa Rubin and Matthew Rosenberg, "US Efforts Fail to Curtail Trade in Afghan Opium”, New York Times, May 26, 2012; Pierre Chouvy, Opium: Uncovering the Politics of Poppy (London: IB Tauris, 2009), 203.

44 Ibid.

45 Associated Press, "US to Shift Approach to Afghanistan Drug Trade", LA Times, June 28, 2009.

46 Senate Caucus on International Narcotics Control, US Counter-Narcotics Strategy in Afghanistan, 11-28. 
In contrast to the ambivalence of the civilian agencies, eradication was something that the military establishment refused to countenance. A more powerful force in Washington than its civilian counterparts, the military weathered criticism from Congress, the media and the White House that it had observed poppy production and opium sales from the sidelines, thereby emboldening participants in the trade. Despite the criticisms, the military continued to eschew involvement in the State Department's eradication strategy. This was because of its cultural aversion to a task outside of its traditional role, but also because its experiences in Afghanistan had exposed the flaws of eradication.

The gulf of understanding between soldiers and commanders that emerged with regard to infrastructure development was absent around the issue of eradication. In an impressive display of solidarity, senior military and DoD officials supported the opinions of US soldiers and vice versa: 'This is not about burning crops or destroying labs. Eventually it is about finding a better option for Afghans who have to feed their families', a Pentagon official declared.$^{47}$ A US General agreed:

I thought eradication was hugely counter-productive because it put the entire weight of the counter-narcotics effort on the farmers - the people you're trying to get on your side and secure from the enemy. Folks that had only that single line of interest were oblivious to that. ${ }^{48}$

Despite protests from the INL and other civilian factions, eradication never featured as a part of US military operations. As Jeffery Eggers, a senior military commander in Afghanistan remarked after a mission in Marja: 'we don't trample the livelihood of those we're trying to win over' ${ }^{49}$ Beyond 2010, the military instead protected poppy fields from the Taliban. When images of this improbable scenario generated media attention, more controversy in Washington ensued: 'It's kind of weird', Lt Adam Lynch, a soldier serving in Afghanistan, states, 'we're coming over here to fight the Taliban. We see this. We know it's bad. But at the same time we know it's the only way locals can make money'. ${ }^{50}$

Given the division within the State Department, and between it and the military, it was hardly surprising that a Senate Committee on International Narcotics control discovered a lack of clarity regarding the US government's policy on eradication. ${ }^{51}$ But rather than taking on board the opposition from the military establishment, and the growing realization by State and Justice Department officials of

47 Thomas Shanker, "Pentagon Sees Aggressive Anti-drug Effort in Afghanistan", New York Times, March 25, 2005.

48 Author Interview with a US Military Commander, Washington DC, April 29, 2012.

49 New York Times, "Fearful of Alienating Afghans, US Turns a Blind Eye to Opium", March 21, 2010.

50 Paul Williams, "US Marines Protect Afghanistan's Poppy Fields", Canada Free Press, July 8, 2009.

51 Senate Caucus on International Narcotics Control, US Counter-Narcotics Strategy in Afghanistan, 4. 
eradication's ineffectiveness, Congress continued to argue that 'crop eradication is a viable tool for narcotics suppression, and as such, should be incorporated into the overall counter-narcotics strategy'. ${ }^{52}$

There was considerably less controversy surrounding the viability of interdiction, but the strategy still generated its own bureaucratic problems. The DEA was considered to be primarily responsible for interdiction operations and the gradual expansion of its presence in Afghanistan was directed toward that purpose ${ }^{53}$ The DEA collaborated with local law enforcement, usually the Counter-Narcotics Police where it trained and monitored a National Interdiction Unit. The DEA, however, lacked air assets and therefore did not have the capacity to conduct the helicopter lifts that were crucial for drug raids. This was compounded by the fact that it had little understanding of operational procedures or collaborative mechanisms that would have helped it to obtain such assets from other agencies. Instead, it called for its own helicopter fleet, under the justification that, according to one DEA official, missions were 'routinely delayed' without 'organic helicopter assets' ${ }^{54}$ This preference to operate autonomously was widely dismissed as unrealistic, unsustainable and costly. The DEA gradually realized the necessity to rely logistically on the military, but there was still difficulty obtaining its support. Much of this was due to poor organization and complicated bureaucratic mechanisms, which hampered cooperation. But as a wing of the Justice Department the DEA also stood outside the broader nation-building mission, and the military did not consider the facilitation of DEA-led interdiction operations to be a priority. ${ }^{55}$

The State Department was more united in its support for interdiction than eradication. Embassy officials and those in Washington continuously advocated the bombing of drug labs in Afghanistan. Holbrooke, whilst strongly against eradication, encouraged aggressive interdiction. The INL and DEA both maintained that US combat units needed to destroy narcotics labs and that the full weight of military resources should be applied to that task. ${ }^{56}$ Yet capturing high-level drug traffickers proved difficult, as the State Department, whose interests still centred on diplomacy, was reluctant to pressure Afghan officials linked to the Karzai government. This, combined with a different understanding of how to approach drug traffickers between the DEA and INL, precluded any agreement on how to establish criteria for low-, mid- and high-level targets. When questioned on the matter, the State Department was reluctant to take the leadership role and instead deferred to the Department of Justice. The GAO rejected this position, arguing

52 Ibid., 8.

53 Government Accountability Office, Afghanistan Drug Control: Strategy Evolving and Progress Reported, but Interim Performance Targets and Evaluation of Justice Reform Efforts Needed, 20.

54 Senate Caucus on International Narcotics Control, US Counter-Narcotics Strategy in Afghanistan, $7-30$.

55 Author Interview with a Senior Defence Department Official, via telephone, Sydney to Colorado, July 15, 2013.

56 Associated Press, "US to Shift Approach to Afghanistan Drug Trade"; Smith, US Peacefare: Organizing American Peace-Building Operations, 80-81. 
that 'State holds the primary responsibility for ensuring that measures to gauge progress exist'. ${ }^{57}$ Still, the State Department had forged strong diplomatic ties with the Karzai regime and it perceived this relationship to be more important than the GAO's demands.

While the military establishment did not actively oppose interdiction, it was still reluctant to embrace it. US forces often did not destroy drugs when they were uncovered, and opium shipments were overlooked if they were attributed to be the property of domestic allies in the War on Terror. Soldiers were criticized for turning a blind eye to drug production. ${ }^{58}$ The main drivers of such a policy were Pentagon and CIA officials, who had embraced the 'warlord strategy'.

In 2005, the military was charged with providing what one Pentagon official described as 'transportation, planning assistance, intelligence and targeting packages' for the DEA. But in drug-ridden provinces such as Helmand, counterinsurgency was inevitably prioritized over support for interdiction. The INL also engaged in interdiction operations. But according to one Pentagon source, the military was disinclined to engage with that agency due to its posture toward eradication. ${ }^{59}$

By 2007, the military had formally acknowledged the link between counternarcotics and counter-insurgency, but the Pentagon took no significant measures to enable interdiction. It was only during an October 2008 meeting that the DoD identified opium traders as military targets, thus strategically linking the insurgency to the drug trade. US forces subsequently engaged with the DEA in jointoperations, although even then military personnel were ordered not to directly participate in arrests. The establishment of the Combined Joint Interagency Task Force-Nexus in Kandahar in 2009 was an organ to coordinate military support for DEA interdiction missions. It too failed to produce a more comprehensive attempt to facilitate a whole-of-government interdiction plan that was linked to an overarching counter-narcotics strategy. By the end of 2010, no inter-agency plan for interdiction existed, which as the Pentagon admitted, created difficulties and compromised mission objectives. ${ }^{60}$

In summary, counter-narcotics stood outside the area of the military establishment's interests, while the efforts of the civilian branches were disorganized and

57 Government Accountability Office, Afghanistan Drug Control: Strategy Evolving and Progress Reported, but Interim Performance Targets and Evaluation of Justice Reform Efforts Needed, $38-39$.

58 Rod Nordland, "US Turns a Blind Eye to Opium in Afghan Town”, New York Times, March 20, 2010.

59 Interview with a Senior Defence Department Official, Washington, DC, April 18, 2012.

60 Government Accountability Office, Afghanistan Drug Control: Strategy Evolving and Progress Reported, but Interim Performance Targets and Evaluation of Justice Reform Efforts Needed, 10; Department of Defence, Report on Progress Toward Security and Stability in Afghanistan, 6; Senate Caucus on International Narcotics Control, US Counter-Narcotics Strategy in Afghanistan, 2; Special Inspector General for Afghanistan Reconstruction (SIGAR), Quarterly Report the United States Congress, 103. 
lacked cohesion. Within the US government there were voices of reason who advocated the implementation of a comprehensive strategy to combat the drug problem, but due to rivalry and parochialism within the State Department, pressure from Congress, and the military establishment's unwillingness to become involved, priorities for the counter-narcotics strategy were varied and coordination was largely absent. Many of the same problems reproduced themselves in efforts to create a functional legal system.

\section{The Legal System}

Without a functioning justice system, individuals and groups take matters into their own hands, which leads to chaos and violence that is redolent of Thomas Hobbes's state of nature. ${ }^{61}$ Much of the reason behind the stability of the Taliban government was its ability to promote and enforce order. Based on an interpretation of Sharia law that fused Pushtun tribal traditions with a fundamentalist Islamic creed, the Taliban imposed a brutal but effective form of justice. ${ }^{62}$

In 2002, an appropriate, functioning legal apparatus may have enhanced the ability of the international community to facilitate a peaceful transition to stable governance in Afghanistan. Achieving this required planning, mentoring, oversight, vetting and training judges and lawyers, constructing legal infrastructure, and providing equipment and expertise. Even then, much like the other nationbuilding issue areas that have been discussed, an overhaul of Afghanistan's legal system needed to overcome embedded challenges. Afghanistan's judicial traditions bear little resemble to western conceptions of Jurisprudence. They have been characterized by a conservative interpretation of Islam that is dispensed at the local level. Religion and justice, although intertwined, still differ between ethnicities (Pushtuns, Harazas, Uzbeks, and Turkmen) and also between tribes. ${ }^{63}$ Consequently, previous efforts to form an equitable justice system could not be harmonized with Afghan tribal practices and religious beliefs. Attempts to enforce a western-style justice system have tended to accentuate conflict rather than overcome it, because they ignored customary traditions and Islamic principles. ${ }^{64}$

This had little bearing on the Bonn Agreement, through which Italy assumed responsibility for the construction of a new, western-style legal order in Afghanistan. But the Italians lacked experience, expertise and resources, which coalesced

61 Thomas Hobbes, Leviathan (Lexington: Seven Treasures, 2009).

62 Ahmed Rashid, Taliban: Militant Islam, Oil and Fundamentalism in Central Asia (London: IB Tauris), 2010, 82-105.

63 Peter Marsden, The Taliban: War and Religion in Afghanistan (London: Zed Books, 2002), 78-87; Thomas Barfield, "An Islamic State is a State Run by Good Muslims: Religion as a Way of Life and not Ideology in Afghanistan", in Robert Hefner, Remaking Muslim Politics: Pluralism, Contestation, Democratization (Princeton: Princeton University Press, 2005), 215-221.

64 Sirat, "The Modern Legal System of Afghanistan", 563-569; Astri Suhrke and Kaja Borchgrevink, "Negotiating Justice System Reform in Afghanistan", Crime, Law and Social Change, $1: 2,211-230$. 
with other problems to create formidable obstacles to the creation of an effective legal system. These problems included the influence of powerful religious factions within the Karzai regime, the relative ignorance of the international community about the distinctive challenges within Afghanistan, and 'pitfalls and contradictions' of the 2004 constitution. As a result, Afghanistan's legal system adopted a fundamentalist bent, embodied by the conservative Supreme Court and antithetical to the international community's aspirations of freedom and equality ${ }^{65}$

In the absence of suitable legal mechanisms, much of the populace relied on local power brokers, tribal authorities and, increasingly from 2005, the Taliban: 'There is no government to deal with cases. The judges, even the lowest civil servants, are corrupt and they want bribes. People go to the Taliban and tribal elders instead to sort out their problems', a farmer from Wardak stated. A foreign aid worker situated in Kandahar agreed, claiming that it was 'no surprise that ordinary people began to seek out the sharia courts of the Taliban rather than those established by the Kabul regime'. ${ }^{66}$

A popular embracing of the Taliban was exactly what the US feared. So why had it not prioritized the construction of Afghanistan's legal system? The US commitment, both in terms of money and labour, compared poorly to the other issues addressed in this book. A 2008 report conducted by the GAO claimed that the justice system 'lagged behind' other US nation-building efforts, while a 2010 report by the DoD admitted that there had been 'little enduring progress despite significant investment toward reform, infrastructure and training'. The Justice Sector Support Program, the largest Rule of Law (ROL) initiative, was allocated $\$ 47.3$ million in 2010, which was much less than projects in other nation-building areas. Other projects, such as the Anti-Corruption and Bribery Office (ACBO), were severely understaffed. After two years of operation the ACBO failed to achieve a single conviction. US projects to build suitable detention facilities were lacklustre and Afghanistan's prisons remained drastically over-crowded. In 2010, most were filled to over four-times their capacity and some as much as ten-times. ${ }^{67}$

The US agencies most involved in the construction of Afghanistan's legal system were the Department of Justice, USAID, the State Department (primarily through the INL), and the military establishment. Unlike the drug issue, which dominated media headlines and was the subject of various governmental

65 Matteo Tondini, “Justice Sector Reform in Afghanistan: From a 'Lead Nation' Approach to a 'Mixed Ownership Regime'?”, Transitional Studies Review, 15 (2009), 665; Thomas Barfield, "Culture and Custom in Nation-Building: Law in Afghanistan", Maine Law Review, 6:2, 369.

66 Loyn, In Afghanistan: Two Hundred Years of British, Russian and American Occupation, 207; Giradet, Killing the Cranes, 332.

67 Department of Defence, Report on Progress Toward Security and Stability in Afghanistan and United States Plans for Sustaining the Afghan National Security Forces, April 2010, 52; Special Inspector General for Afghanistan Reconstruction (SIGAR), Quarterly Report the United States Congress, 80; James Risen, "Poppy Fields are now a Front Line in Afghan War", New York Times, May 16, 2007; Special Inspector General for Afghanistan Reconstruction (SIGAR), Quarterly Report the United States Congress, 83. 
committees, Afghanistan's legal system was essentially ignored in Washington. Although Congress and the White House were aware of the problems that a legal vacuum raised, they put it near the bottom of their list of priorities.

National Security Presidential Directive 44 tasked the Secretaries of State and Defence with coordinating justice sector reform. But the various agencies operating in Afghanistan were placed under no significant pressure to actually initiate rule of law projects. Agency neglect arose from the fact that the construction of a legal system did not sit within the area of expertise of any of the agencies involved, nor was it in their interests to lead the US ROL programme, given the array of other responsibilities that they had already accepted.

Reports by various parties within the US bureaucracy associated ROL projects with a broader nation-building programme. A 2006 report, for example, described the justice system as 'critical to the success of implementing rule of law, protecting human rights, and gaining public confidence in government'. But four years later there remained no estimate of the cost or method by which to develop Afghanistan's legal system, and no significant attempts to coordinate a cohesive approach. ${ }^{68}$

Afghanistan's security forces were tied to the legal system in a 2009 by the United States Institute for Peace, which stated that 'the best trained police are of minimal utility in securing public safety if the attorney general's office and judiciary are not adequately functional'. ${ }^{69}$ Chapter 4 showed that the Pentagon and the State Department dedicated significant resources, man-power and money to the ANP. It is astounding, therefore, that neither agency perceived a link between their efforts to strengthen the ANP, on the one hand, and the need to develop an appropriate legal system on the other. Such obliviousness is a testament to the impact that agency culture can have on the behaviour of its officials, and more specifically their inability to integrate an unfamiliar issue within a broader policy framework. ${ }^{70}$

Simply identifying which agency had been allocated funding proved to be extremely difficult due to blurred lines of authority and disorganization, both within the civilian realm and between the civilian branches and the military establishment. In 2008, the State Department's Office of the Inspector General lamented that 'there is currently no way to readily identify ROL funding and subsequently identify duplicate programs, overlapping programs, or programs conflicting with each other'. Funding estimates differed between agencies and the

68 Inspectors General, US Department of State and US Department of Defence, Interagency Assessment of Afghanistan Police Training and Readiness, November 2006, 52; Eric Jensen and Amy Pomeroy, "Afghanistan Lessons Learned: Army Rule of Law Operations", in Michael Schmitt (ed.), The War in Afghanistan: A Legal Analysis, International Law Studies, Volume 85, 470.

69 Seth Jones and Christine Fair, Securing Afghanistan, Getting on Track. United States Institute of Peace Working Paper, January 23, 2009, 16.

70 United States Department of State and Board of Broadcasting Governors, Report of Inspection Rule of Law Programs in Afghanistan, Office of the Inspector General, January 20, 2008, 2. 
military, and no faction within the US bureaucracy could provide 'a clear picture' of US expenditures. ${ }^{71}$

In contrast to other areas such as security, infrastructure development and counter-narcotics, moreover, there was no self-evaluation by the agencies involved in justice sector reform. The State Department, Department of Justice and Department of Defence failed to conduct formally documented performance evaluations of Afghanistan's justice programme. According to the GAO, a lack of data or exchange of information between agencies prevented projects such as the Justice Officials Tribunal, Criminal Task Force and the Justice Center from achieving their, admittedly vague, goals. ${ }^{72}$

The Congressional Research Service (CRS) estimated that spending for ROL projects by civilian agencies increased from $\$ 7$ million in 2002, to $\$ 411$ in 2010. Overall, the CRS found that the State Department and USAID had access to $\$ 904$ million in funds for these purposes from 2002 to 2010. A number of bureaucratic factions were involved in a fractious assortment of initiatives. The INL was allocated the lion's share of the money, $\$ 684$ million, for justice system and corrections system development. ${ }^{73}$ Although these two areas were purported to be its main focus, the INL was also involved in enterprises such as the United Nations' Afghan Criminal Justice Task Force and the Afghan Central Narcotics Tribunal. These two projects were more compatible with its culture, which, as we have learned, centred on combating the international narcotics trade while placing the rule of law as a secondary concern.

The INL's devotion to counter-narcotics helped to sway the US decision to construct the Counter-Narcotics Justice Center (CNJC), which opened in 2009, at the cost of $\$ 11$ million. The CNJC was monitored by the State Department and the Department of Justice and it housed Afghanistan's Criminal Justice Task Force. Despite forming a united front when the CNJC was criticized by the US media, ${ }^{74}$ the INL and the Justice Department bickered over its effectiveness. INL officials argued that its detention centre was filled with low profile drug criminals, who were irrelevant characters who had no connection to the international operations of Afghanistan's drug barons. Alternatively the Department of Justice claimed

71 Francis Ward, Deputy Assistance Inspector General for Inspections, Oversight of US Efforts to Train and Equip Police and Enhance Justice Sector Reform in Afghanistan, Committee on Oversight and Government Reform, June 18, 2008; Inspector General, United States Department of State, Rule of Law Programs in Afghanistan: Report of Inspection, United States Department of State, January 2008, 1.

72 Government Accountability Office, Afghanistan Drug Control: Strategy Evolving and Progress Reported, but Interim Performance Targets and Evaluation of Justice Reform Efforts Needed, 6-35.

73 Liana Wyler and Kenneth Katzman, Afghanistan: US Rule of Law and Justice Sector Assistance, Congressional Research Service, November 9, 2010, 27.

74 Joshua Hersh, “Afghanistan's US funded Counter-Narcotics Tribunal Convicts Nearly All Defendants, Records Show", Huffington Post, June 10, 2012, http://www.huffingtonpost.com/2012/06/09/ afghanistan-counter-narcotics-tribunal_n_1580855.html (accessed 10/06/2012). 
that low-level drug traffickers would help the United States gain access to higher value targets. ${ }^{75}$

Setting this bickering aside, the Department of Justice prima facie seemed to be the more appropriate agency to spearhead the development of Afghanistan's new legal order. But it was unsuitable for that assignment for three reasons. First, it had no access to separate funds. Second, constructing an entire legal system in an alien environment was something for which the Department of Justice was unprepared. Third, as the case of the CNJC exemplifies, when it comes to overseas activities, the DEA is the most prominent force within the department, and its interests centre on combating illicit drug production and trafficking, and prosecuting criminals and drug gangs, rather than ROL projects. ${ }^{76}$

Unlike the Department of Justice, USAID did have access to separate funding, which it used to pursue its own Rule of Law Project from 2004 to 2009. In total, USAID spent approximately $\$ 67$ million on justice reform, but its projects overlapped with those conducted by the INL. Other enterprises such as the High Office of Oversight and the Anti-Corruption, Control and Audit Office, and the Major Crimes Task Force, were loosely supported by a complex and varying amalgam of agencies, which included the INL, USAID, State Department, Justice Department, the Department of Treasury and the FBI. These and other ROL programmes were coordinated in Kabul through a Special Committee on the Rule of Law, and in Washington by the Afghanistan Justice Coordination group. But each of the two bodies had different mission platforms and goals. Thus neither functioned as an overarching coordination mechanism: 'Our plunge into judicial assistance was chaotic', Neumann states; 'USAID ran some programs through contractors, State had its own contracts but was also paying for several experienced prosecutors on loan from the Department of Justice, who often seemed to operate independently' ${ }^{77}$ One Senior State Department Official was quite candid in his admission that the State Department had mishandled the reconstruction of Afghanistan's legal system and acknowledged that it had other interests that took priority:

In fairness to others, it took me a while to understand I could not supervise this myself. Even when I had some ideas and knew where I wanted to be and where I wanted to go, I was constantly drawn off by a military crisis, a drug crisis, or a political crisis, and so supervision would lapse for a period of time until I could come back to it. $^{78}$

75 Special Inspector General for Afghan Reconstruction (SIGAR), Documenting Detention Procedures Will Help Ensure Counter-Narcotics Justice Center is Utilized as Intended, SIGAR Report, December 30, 2009, 3.

76 Wyler and Katzman, Afghanistan: US Rule of Law and Justice Sector Assistance, 32; Greg Lee, Global Drug Enforcement (London: CRC Press, 2004, 3), 13-15; Drug Enforcement Administration, Mission Statement at http://www.justice.gov/dea/about/mission.shtml (accessed 25/09/2013)

77 Ronald Neumann The Other War: Winning and Losing Afghanistan.

78 Author Interview with a Senior State Department Official, Washington DC, April 18, 2012. 
Eventually, he overcame the problem by appointing someone to control and oversee the justice programme, which integrated the State Department's activities in Kabul, but did nothing to address the blurred lines of authority between it and other agencies. Realistically, the appointment had no power outside of the US Ambassador's narrow sphere of authority. From an idea initially conceptualized by Neumann, the position of Coordinating Director for Rule of Law and Law Enforcement evolved in 2010. But there is little evidence that the position carried weight outside of the State Department. ${ }^{79}$

A final problem with the civilian approach to legal reform in Afghanistan was that civilian advisors were corralled in Kabul, because their agencies did not have the power or capability to reliably operate outside of Afghanistan's capital. The Assistant Secretary of State, David Johnson, admitted that justice sector reform outside Kabul was in 2008 'fairly rudimentary'. Thus civilian ROL officials were absent from approximately 90 per cent of Afghanistan. ${ }^{80}$

The amount of funding that the military dedicated to ROL projects proved to be even more difficult to ascertain than the expenditures of the civilian branch. A 2008 OIG report, for example, contended that there was "no way to determine what the many different elements of the DoD were spending specifically on ROL' ${ }^{81}$ In contrast to civilian efforts, which were restricted to Kabul, the military took an approach that focused on ROL projects in Afghanistan's conflict-ridden southern provinces. Naturally, it did this in adherence to the all-encompassing strategy of COIN. CERP funds were used to construct judicial systems at the provincial and local level, while another programme centred on securing transport for judges and prosecutors in dangerous areas. The military establishment looked to the Judge Advocate General's Corps (JAG) to organize many of these projects, but JAG officers had no experience in constructing a legal system and they were deployed 'without guidance or training' ${ }^{82}$

Notwithstanding the fact that it incorporated ROL projects within the auspices of COIN, however, the military proclaimed that it was unsuited to justice sector reform because its culture was, according to a report conducted by the US Army, 'different from the rest of the interagency'. 'The military skill sets', the report argued, were 'better suited to restore economic and industrial power'. An Army Handbook, meanwhile, argued that creating a secure environment 'may

79 Thomas Nachbar, "Counter-Insurgency, Legitimacy and the Rule of Law”, Parameters, Spring, 2012, 27-38.

80 David Johnson, Assistant Secretary of State, Testimony for Oversight of US Efforts to Train and Equip Police and Enhance Justice Sector Reform in Afghanistan, Committee on Oversight and Government Reform, United States Department of State, International Narcotics Bureau, June 18, 2008.

81 United States Department of State and Board of Broadcasting Governors, Report of Inspection Rule of Law Programs in Afghanistan, 2.

82 Wyler and Katzman, Afghanistan: US Rule of Law and Justice Sector Assistance, 33; Jensen and Pomeroy, “Afghanistan Lessons Learned: Army Rule of Law Operations”, 467. 
be the only real contribution that US forces can make towards implementing the rule of law', ${ }^{83}$

Despite recognizing that it was unqualified, and indeed uninterested, in conducting justice sector reform outside of the parameters of COIN, the military claimed that civilian agencies would not accept military leadership and that the civilian branches had no perception of how to operate under unity of command. This incompatibility determined that coordination among elements was weak and relations were strained. Even more so than with counter-narcotics, the military and civilian spheres operated in separation. ${ }^{84}$

An example of this disharmony was the construction of the Counter-Narcotics Justice Center. The project was used as an illustration of effective civilian-military collaboration ${ }^{85}$ but upon closer inspection this was not the case. The State Department had contracted the United States Army Corps of Engineers (USACE) to construct the CNJC. But the USACE refused to conduct the recommended utility upgrades, because 'funds provided under the interagency agreement were no longer valid'. The State Department assured the USACE that the funding was indeed still valid, but they would not listen. ${ }^{86}$ We can speculate that the USACE was frustrated by the slowness of the State Department to act, which highlights the incompatibility of the two agencies' procedural norms.

The fight against the Taliban-led insurgency had a pernicious effect on all attempts to construct a fair and equitable legal order. US combat operations, according to a long-standing tenet established first in FM31-15, must be 'conducted in consonance with specified civil rights, liberties, and objectives ${ }^{97}$ A legal void, however, existed within the orbit of combat operations, as the military establishment ferociously pursued a war-fighting mandate. In prosecuting the GWOT, the Pentagon and the CIA blatantly ignored Afghanistan's laws. Although civilians were often targeted, tortured and killed, US troops were not called to account for their actions. Afghan prisoners were perceived to be military property, while US citizens who committed crimes in Afghanistan did so with impunity.

83 United States Army, Leader Challenges: Operation Enduring Freedom and Operation Iraqi Freedom, Center for Army Lessons Learned, Fort Leavenworth, Kansas, December 2005, 18; United States Army, Rule of Law Handbook: A Practitioners Guide for Judge Advocates (Virginia: Center for Law and Military Operations, 2010), 12.

84 Author Interview with a Senior State Department Official, Washington DC, April 18, 2012; Author Interview with a Senior Defence Department Official, via telephone, Sydney to Colorado, July 15, 2013.

85 Government Accountability Office, Afghanistan Drug Control: Strategy Evolving and Progress Reported, but Interim Performance Targets and Evaluation of Justice Reform Efforts Needed, 6

86 Special Inspector General, Afghanistan Reconstruction (SIGAR), Action Needed to Resolve Construction Delays at the Counter-narcotics Center, SIGAR Report, August 27, 2009, 3-4.

87 FM 31-15, Operations Against Irregular Forces, Department of the Army, May, 1961, 4. This was then implanted as part of COIN in Afghanistan in October 2006; United States Army, Southern Afghanistan COIN Operations Handbook: Tactics, Techniques and Procedures, Center for Army Lessons Learned, October, 2006, 24. 
One report found that 'despite several homicides by US officials and contractors . . none of the guilty have received significant sanctions' ${ }^{88}$

Interrogations were conducted at Bagram airbase. One such interrogation resulted in an Afghan prisoner being brutally beaten to death by a CIA operative. Other prisoners were subject to noise torture. An Afghan translator revealed that US Special Forces 'punish those who would not confess with a very terrible kind of "music" . As the military's primary focus was on defeating the enemy, Bagram and other military bases across Afghanistan became 'ransomed by bounty hunters seeking compensation or by personal foes who, pursuing vendettas unrelated to real crimes, denounced them to the Americans as "al-Qaeda" and "Taliban", 89 Thus, although the US military had not deliberately set out to topple Afghanistan's justice system, its actions contributed to the failure to build a functioning legal system in Afghanistan. This alienated many of the hearts and minds the Pentagon claimed to be cultivating.

\section{Governance}

Along with a legal system, governments are required for a functioning society and are essential for order, and, ultimately, prosperity. But since the misadventures of the Soviet Union, Afghanistan has been wrecked by institutional illegitimacy, fractured community trust, and a depletion of social capital. Nation-building in 2001 was supposedly a panacea for these problems, 'a short-cut to the Weberian state', that skips the 'long, conflictual and often brutal evolution that historically underlies the formation of states'. ${ }^{90}$

The responsibility for constructing a new political order in Afghanistan was firmly in the hands of the United States and its allies. The US, above all, had the power to shape the country's government, institutions and bureaucracy into a form that would be beneficial for the Afghan people. When asked what the US role in Afghanistan would be after the invasion, however, Donald Rumsfeld responded with: 'I don't think that leaves us with a responsibility to try to figure out what kind of government that country ought to have'. Rumsfeld, a staunch realist, was not convinced that a 'democratic tsunami' could engulf Afghanistan. ${ }^{91}$ Yet others within the Bush Administration had ambitions to transform the country

88 Ti Golen and Eric Schmitt, "A Growing Afghan Prison Rivals Bleak Guantanamo", New York Times, February 26, 2006; Barnett, Afghanistan's Uncertain Transition From Turmoil to Normalcy, 19.

89 Scott Shane, "CIA Interrogator's Defence to Cite Bush at Brutality Trial”, New York Times, February 11, 2005; Farhad, Zabih (pseudonym) quoted in Nick Turse (ed.), The Case for Withdrawal in Afghanistan (London: Verso, 2010), 143. Atiq Sarwari and Robert Crews, "Afghanistan and the Pax Americana", 342.

90 Alley, International Conflict and the International Community: Wars Without End?, 165; Ottaway, "Rebuilding State Institutions in Collapsed States", 1004.

91 Ivo Daalder and I.M. Destler, In the Shadow of the Oval Office: Profiles of the National Security Advisers and the Presidents They Served - from JFK to George W Bush (New York: Simon and 
into a thriving liberal state, to buttress its quest for global democracy: 'Liberating the suffering people of Afghanistan was necessary and just' rejoiced President George W. Bush, who claimed that he was 'overjoyed by the scenes of liberation' in Afghanistan, and that the United States was committed to 'helping a democratic government emerge'. Dick Cheney, the Vice President, also emphasized the US commitment: 'in this journey of freedom and progress, they will continue to have the full support of America'. The President's wife, Laura Bush, on a 2005 visit to Afghanistan was convinced 'that tyranny has been replaced by a young democracy and the power of freedom is on display'. Recently appointed Secretary of State, Condoleezza Rice, made a similar observation during her visit to the country in March 2006, concluding that there was "no better story of democratic development'.92

The tsunami, however, was mostly in the form of rhetoric, rather than practical commitment. Some US sources criticized the US approach as myopic, and called for a systematic overhaul to reflect disparate tribal power structures in Afghanistan. ${ }^{93}$ But the White House was unmoved, and continued to support centralized government justified by some sort of vague democratic mandate. This ignored the fact that Afghanistan had formidable cultural, political, geographical and historical barriers to the crystallization of democracy. As Johnson and Jolyom state, the country was not 'a blank canvas on which the outside world could paint the colors of its choice'. ${ }^{94}$ Diverse tribal hierarchies jostled for power in Afghanistan's nebulous political landscape, and the hostility between Pushtuns and Afghans of other ethnic stripes continued unabated.

Traditionally, the State Department's interests centre on diplomacy. It was the logical choice, therefore, to help establish and subsequently interact with the Afghan government. The State Department dominated US involvement in Afghan politics at the national level, which left little room for USAID and other civilian agencies to accrue favour with, or influence the behaviour of, Afghanistan's government. The military, meanwhile, allowed the State Department this power, under the condition that it pressured the Afghan government to maintain constant support for the war effort.

The US approach to governance was deeply problematic from the outset. Zahir Shah, the former Afghan monarch, was sidelined from the political process to perform a ceremonial role. Instead it was pro-US Afghan exiles who were brought

Schuster, 2011), 270; Mark Danner, "Rumsfeld's War and its Consequences Now", New York Review of Books, December 19, 2013, 4.

92 Bush, Decision Points, 194-200; Carlotta Gall, "Cheney and Afghan Milestone", New York Times, December 20, 2005; New York Times, "Laura Bush Carries Pet Causes to Afghans", March 31, 2005; Joel Brinkley and Carlotta Gall, "Rice Calls Afghans Inspiring, but Election is Delayed Again", New York Times, March 18, 2005.

93 Mark Mazzetti and Eric Schmitt, "US Study Is Said to Warn of Crisis in Afghanistan", New York Times, October 8, 2008.

94 Johnson and Jolyom. Afghanistan: The Mirage of Peace, 176. 
into government with US support. Foremost among these figures was Hamid Karzai, Afghanistan's long-standing President (2004-2014). Karzai was in many respects a US puppet, of the same breed as the Afghan rulers whom the British and Soviets had placed on the throne in Kabul. The State Department convinced Afghan delegates at the Bonn Conference to vote for Karzai, despite the fact that many of them had never heard of him..$^{95}$

Following an attempt on his life, the Afghan President was placed under constant guard by American Special Forces. He was perceived by his countrymen to be 'just the mayor of ISAF-policed Kabul, nothing more'. ${ }^{96}$ Karzai's influence never stretched much beyond Kabul, and although Afghanistan's capital was depicted by the State Department as a beacon for democracy, it was, at best, a lighthouse in a storm. ${ }^{97}$ Conditions in Kabul bore no reflection of the political conflict and turmoil that roiled beyond its outer limits.

The weight of the State Department's power over Karzai's regime was reinforced by the fact that Zalmay Khalizad, the US Ambassador to Afghanistan from 2003 to 2005, was often described as the second President of Afghanistan. The country's 'first President' often submitted to the US Ambassador while other State Department officials were even responsible for structuring his major speeches. ${ }^{98}$ Within the State Department, however, there were rumblings indicating that support for Karzai was not unanimous. An internal memo in May 2005 warned that part of the reason behind the growth of Afghanistan's heroin trade was that Karzai 'has been unwilling to assert strong leadership'. By contrast, State Department spokesman Richard A. Boucher described the Afghan President as 'a strong partner', saying 'we have every confidence in him' to correctly address the drug problem in concert with the US. For the most part, therefore, the State Department presented a united front to the public and was reluctant to defy the White House, which had given it clear orders to support the Karzai government, regardless of its many flaws. ${ }^{99}$

The rampant corruption embedded within the Afghan national government was thus tolerated by the United States. Karzai functioned as 'a nineteenth-century Durrani nobleman, refined by the warlord ethics of the late twentieth century'. ${ }^{100}$ His relatives won most of the lucrative infrastructure development contracts that they applied for, and the President's inner circle was widely considered to be crooked and autocratic. In 2007, Craig Murray, Britain's Ambassador to Uzbekistan from 2002 to 2004, contended that 'the four largest players in the heroin

95 Dorronsoro, Revolution Unending, 330; Peter Maas, "Gul Agha Gets His Province Back”, New York Times, January 6, 2002.

96 Wawro, Quicksand: America's Pursuit of Power in the Middle East, 507.

97 Carlotta Gall, "From the Rubble: A City of Old? Or All Shiny and New?" New York Times, June 27, 2005.

98 Sinno, Organizations At War, 259-60.

99 David Cloud and Carlotta Gall, "US Memo Faults Afghan Leader on Heroin Fight", New York Times, May 22, 2005.

100 Loyn, In Afghanistan: Two Hundred Years of British, Russian and American Occupation, 304. 
business are all senior members of the Afghan government'. There is evidence to suggest that the United States was well aware of Karzai's corruption, but it still failed to take substantive action besides sporadic rhetorical pressure. ${ }^{101}$

In the eyes of many Afghans, the Karzai government and the US were one and the same. 'The Americans are very powerful and they can control the government... but if the people don't like them, they will have to leave', one Afghan observed during an anti-government protest. In 2007, protests became more emotive, with frustrated Afghans throwing rocks at the police and chanting, 'Death to America! Death to Karzai!' 102 The military establishment was oblivious to the fact that the unpopularity of the Afghan government directly contributed to the strength of the Taliban-led insurgency, which provided the only substantive domestic alternative to Karzai's incorrigible ruling clique.

The military establishment was elated by its swift victory over the Taliban in 2001, which prompted Tommy Franks, the Commander of US Central Command from 2000 to 2003 , to claim that the US had 'liberated not conquered their nation' ${ }^{103}$ But once victory had been achieved the US military was nonplussed as to the form of government that was erected. Ryan Crocker, the interim chargé d'affaires to the government of Afghanistan from 2002 to 2004, highlighted the different interests between the State Department and the Pentagon:

We were asking how can central authority be established ... The Pentagon's view was our job is done and let's get out of here. We got rid of the evil and we should not get stuck. ${ }^{104}$

While the State Department held sway over US policy in Kabul, the military was the only actor with a significant presence throughout the remainder of the country. It alone within the US foreign policy bureaucracy, therefore, had the power to influence the shape and nature of governance in Afghanistan's rural sphere.

Once the Taliban-led insurgency emerged to challenge the Karzai regime in 2004, the US military presence in Afghanistan strengthened and its attitude seemingly shifted. Eikenberry acknowledged that 'the longer term threat is the loss of legitimacy of the government of Afghanistan', arguing that 'we need more urgency to build Afghan government capacity and help connect it to the Afghan people'. A DoD report in 2008 stated that 'effective governance is crucial to achieving US

101 Chatterjee, "Paying off the Warlords", 86; Fitzgerald and Gould, Invisible History, 295; Jonathan Steele, "US Convinced Karzai Half-Brother is Corrupt, Wikileaks Cables Say", The Guardian, December 3, 2010; http://www.theguardian.com/world/2010/dec/02/us-karzai-half-brotherwikileaks (accessed 3/3/2013); Helene Cooper and Jeff Zeleny, "Obama warns Karzai to focus on Tackling Corruption", New York Times, November 2, 2009.

102 Carlotta Gall, "Mood of Anxiety Engulfs Afghans as Violence Rises", New York Times, June 30, 2005; Carlotta Gall, "16 Civilians Die as US Troops Fire on Afghan Road”, New York Times, March 5, 2005.

103 Franks, American Soldier, 325.

104 Rashid, Descent into Chaos, 136. 
objectives in Afghanistan and facilitating the country's independence'. ${ }^{105}$ Many US soldiers seemed attuned to the importance of governance for nation-building: 'Victory, however you define it, will come when the Afghan government is capable of providing security and some semblance of prosperity and welfare for the people', Lt Benjamin Tupper stated. ${ }^{106}$ Another soldier astutely recognized why government is important, in a New York Times opinion piece:

When ordinary people lose their faith in their government, then they also lose faith in the foreigners who prop it up. The day that happens across Afghanistan is the day we lose the war. ${ }^{107}$

Such awareness did not translate into a nationwide policy that encouraged grassroots, popular governance. As with each other nation-building issue discussed in this book, the Pentagon based its approach on how Afghanistan's political environment would affect its combat operations and complement COIN. It failed to prevent corruption at the provincial and local level if the corrupted supported, or at least pretended to support, the war against the Taliban-led insurgency, and did little to assist US soldiers in the field who attempted to do more. In Kandahar, public office was for sale to the highest bidder, who then quickly became rich thanks to bribes and other criminal activities. District and provincial governors, moreover, were often able to convince the US military to attack their rivals. In mid-2006, when fighting broke out between Rashid Dostum and Abdul Malik, two of the most notorious warlords, they continued to be treated as 'linchpins of local security' ${ }^{108}$ An unwillingness to mediate this and other conflicts directly contradicted the pretence of 'winning hearts and minds', and lent further weight to the hypothesis that the military was far more interested in war-fighting than genuine nation-building. The military also failed to recognize how its tolerance of corruption and violence from pro-US authority figures hampered infrastructure development. As one Afghan civil society representative expostulated: 'schools or clinics are useless if people hate the district level administration. What can you build so that a community will accept a corrupt or brutal leader?' ${ }^{109}$ At the same time as turning its back on good governance at the provincial and local level, however, the military establishment hypocritically supported elections.

Elections are perhaps the most significant hallmark of democracy. Pei and Kasper, however, view elections as 'a challenge beyond the capacity of even

105 Committee on Armed Services, Assessment of Security and Stability in Afghanistan and Development in US Strategy and Operations, 8; Department of Defence, Report on Progress Toward Security and Stability in Afghanistan, 41.

106 Tupper, Greetings from Afghanistan: Send More Ammo, 58.

107 Nathaniel Fick and Vikram Singh, "Winning the Battle, Losing the Faith", New York Times, October 4, 2008.

108 Ali, "Mirage of a Good War", 56; Sarwari and Crews, "Afghanistan and the Pax Americana", 337.

109 Sarah Chayes, "Care and Feeding of the Taliban”, New York Times, July 9, 2006. 
the most well-intentioned and determined outsiders', while Maley considers them to be 'logistically the most complicated events that can be undertaken in peacetime'. ${ }^{110}$ Nonetheless, in Afghanistan the US argued that Presidential and Parliamentary elections were the presuppositions for democracy and all of the beneficial effects that flow from it. For the White House, which neglected other nation-building issues, elections were the main nation-building priority. In the lead-up to the first Presidential elections in 2004, it pressured USAID contractors to push ahead with nation-building projects, notwithstanding that they required more time or reassessment. Patrick Fine, USAID's Mission Director from 2004 to 2005 , experienced 'intense pressure to get work underway immediately and to deliver finished school proper to the scheduled June (2004) presidential election'. 'It was a political timeline', one contractor noted, 'that has created all of the problems'. The 2004 presidential elections were hailed by President Bush as a democratic milestone. Yet the support of the White House did not reflect a US interest in Afghanistan's political future, but rather a way to erect a chimera that presented the country as a success story to domestic US constituents and the US media. ${ }^{11}$

Parliamentary elections, which were slated by the Bonn Agreement to coincide with the Presidential elections, were not held until mid-September 2005. The Afghan people's discontent was more conspicuous than during the Presidential elections, and so was the intimidation of those that chose to participate. On 25 June, 2004, 16 recently returned refugees were killed by the Taliban for carrying voter registration cards. Many Afghans simply did not turn out to vote. One village elder said that if he were to vote, 'I won't stay alive for very long', remarking to American soldiers that 'you guys are very nice, but you only come around once in a while. The Taliban will come here as soon as you are gone'. ${ }^{112}$ Without a reliable security presence, candidates relied on militias and armed assistance to rise to power.

Once again, the White House was concerned that the Parliamentary elections progressed smoothly, and ignored both the security problems and a lack of faith from Afghans in the ability of the elections to produce candidates who reflected the will of their constituents. During her visit to Afghanistan, Rice's main concern was to prevent the elections from being further delayed. She remained staunchly unwilling to criticize the Afghan government, instead parroting the narrow message of her administration that presented elections as the embodiment of democracy. Similarly, General Barno claimed that COIN was having 'positive and dramatic' results because it helped to ensure that Presidential and Parliamentary elections were held. ${ }^{113}$ The US perspective, however, is described by Fitz and

110 Pei and Kasper, "Lessons from the Past", 5; Maley, Rescuing Afghanistan, 46.

111 O'Hanlan and Hassina, Toughing It Out in Afghanistan, 2.

112 Robichaud, "Remember Afghanistan? A Glass Half Full, On the Titanic", 17.

113 Joel Brinkley and Khapalwak Ruhulah, "Rice, Visiting Violent Afghanistan, Still Finds Political Progress", New York Times, October 13, 2005; Barno, "Fighting 'The Other War': Counterinsurgency Strategy in Afghanistan, 2003-2005”, 42. 
Gould as 'a frightening self-delusion' and many Afghans perceived the results of the two elections to be 'a negative symbol of US influence'. ${ }^{114}$

Female politicians, who according to US rhetoric had been empowered by Afghanistan's new democratic order, remained impotent and beset by prejudice. One female MP claimed that she had almost become a prisoner in her own home again, and stated that 'for all this I blame America'. 'Equal rights for women [were] illusory ... a polite feel-good fiction that helped to sell the American enterprise at home', Jones observes. ${ }^{115}$

The Presidential and Provincial Council Elections in 2009, and the Parliamentary elections in 2010, were similarly problematic. Violence and the discontent of the Afghan people increased, and vote tampering was common. But US support for the elections, and by extension the Karzai regime, remained the same. The most tangible indication of US involvement in the 2009 and 2010 elections was USAID's Afghanistan Presidential and Provincial Elections Observation Program. USAID - with the help of the International Foundation for Electoral Systems (IFES) and the Consortium for Election and Political Process Strengthening (CEPPS) - engaged in civil education, anti-fraud and electoral observation. Although the agency claimed it had spent $\$ 124.5$ million in total from 2008 to 2011, this number is misleading. Half of the funds were contracted to outside parties, while another portion of the funds were managed by the IFES. Again, we can see that USAID's culture and lack of power prompted it to outsource, and once again it failed to conduct contractor performance reviews. The agency argued that 'the lack of security was the greatest challenge to observing these elections', but this precipitated no attempt to collaborate with the military establishment to overcome that problem. ${ }^{116}$ For these reasons, USAID's fleeting commitment to electoral monitoring and reform had little impact on the elections, which caused destabilization, reactivated or exacerbated tribal and ethnic grievances, and reinforced the authority of regional and local autocrats. ${ }^{117}$

Although they were few and far between, there were other mechanisms to promote governance devised by the US, based around civil servant training and local governance and community development. These were promoted through district community councils, in order to 'improve basic governance and public service

114 Fitzgerald and Gould, Invisible History, 273; Rashid, Descent into Chaos, 140.

115 Chris Sands, "Chaos Central", in Nick Turse (ed.), The Case for Withdrawal from Afghanistan, 68; Jones, In the graveyard of Empires, 97.

116 Office of the Inspector General, Audit of USAID/Afghanistan's Support to the Electoral Process and Support for Increased Electoral Participation in Afghanistan's Programs, Kabul, June 19, 2011, 1-11; Special Inspector General for Afghanistan Reconstruction (SIGAR), Quarterly Report the United States Congress, 69.

117 Noah Coburn and Anna Larson, Derailing Democracy in Afghanistan, Elections in an Unstable Political Landscape (New York: Columbia University Press, 2013). 
delivery'. ${ }^{118}$ But because they lacked the capacity to operate in rural Afghanistan, the civilian agencies outsourced the projects and often lacked the power or will to monitor them. Robert Finn, the US Ambassador to Afghanistan from 2002 to 2003, also points to fundamentally different interests between the State Department and USAID in respect of the importance of governance for nation-building:

I was trying to get USAID to train civil servants, but . . . USAID was focused on building schools, not training Afghans how to manage the system to build the school ... They said they couldn't do both . . . USAID said, 'We don't do physical construction, we do long-term projects like irrigation' . . But longterm didn't mean training bureaucrats. ${ }^{119}$

This observation supports the findings of the previous two chapters, which demonstrated that USAID's interests, culture and perceptions were far removed from those of the State Department.

\section{Conclusion}

An examination of counter-narcotics and the justice system both revealed divisions within the US foreign policy bureaucracy. While there was not as much conflict as there was in respect to security and infrastructure development, counter-narcotics still provoked debate over the appropriate policy. Eradication was considered to be the most attractive strategy by the INL and some individuals within the State Department. The military, however, did not share that assessment and refused to participate in US-driven eradication. The Pentagon showed similar reluctance to engage in interdiction, while the DEA struggled to implement its policies and programmes, primarily due to a lack of resources and influence, both in Washington and Afghanistan. The justice system, meanwhile, was essentially ignored by all of the relevant US agencies because it sat well beyond their areas of interest and expertise. The military also refused to adapt its behaviour to conform to Afghanistan's laws, and no US agency could unite the elements of the bureaucracy to construct an overarching policy platform for legal reform.

What separates the US approach to governance from all of the other nationbuilding issues discussed was the interest of the White House. The executive branch, led by President George W. Bush, insisted that democracy, and by extension, elections, were the main priority of the US in Afghanistan. The ambitions of the White House were presented as a means to ensure better circumstances for the Afghan people, but were more realistically a cloak to hide a more base

118 Department of Defence, Report on Progress Toward Security and Stability in Afghanistan, 34. Special Inspector General for Afghanistan Reconstruction, Quarterly Report the United States Congress, 75.

119 Yodsampa, No-one in Charge, p. 105. 
interest - presenting the country as a successful case of US intervention, in contrast to Iraq. A centralized model of governance and elections failed to promote stability and egalitarianism, despite the more genuine, but perhaps similarly deluded, efforts of the United Nations. Ironically, while the US was considered to be the veritable power behind the throne, it left most of the practical preparation for elections, and other mechanisms of governance, to the rest of the international community. There was little in the way of inter-agency conflict due to the fact that the State Department dominated diplomatic relations with the Afghan regime, and developed a rapport with Afghan President Karzai. Outside of the capital, however, the State department was essentially non-existent and the military's approach to provincial and local government centred on the myopic understanding that autocratic figures promoted stability. The more practical endeavours of constructing a civil service, mechanisms for local governance and anti-corruption initiatives were given much less attention, even at the height of COIN. ${ }^{120}$ Counter-narcotics, justice sector reform and governance, therefore, joined security and infrastructure development as failed aspects of US nation-building in Afghanistan.

120 Ernesto Londoño, "Survey of Afghans Points to Rampant Corruption in Government", Washington Post, July 8, 2011; T.S. Allen, "Addressing an Ignored Imperative, Rural Corruption in Afghanistan”, Small Wars Journal, February 19, 2013. 


\section{Part III}

\section{Avenues for Inter-Agency Cooperation}





\section{The Failure of Collaborative Mechanisms}

Part II of this book examined the ways in which inter- and intra-agency disorder was spread across multiple areas of nation-building in Afghanistan. This arose from the failings of political leadership on the one hand, and differences in bureaucratic interests, perception, culture and power, on the other. Part III now turns to the mechanisms that were devised to bridge divisions between and within agencies, and assesses their effectiveness. As we have seen in some of the earlier examples, US agencies, and indeed factions within agencies, are aggressively territorial and resistant to change. Consequently, any institutional mechanisms designed to improve cooperation were always going to struggle to impact upon ingrained norms and behaviour. As Wilson observes, 'no agency head is willing to subordinate his or her organization to a procedure that allows other agencies to define its tasks or allocate its resources'. ${ }^{1}$ This statement distils one of the central problems confronting US nation-building in Afghanistan, and relates to one of the main reasons for institutional innovations that sought to overcome bureaucratic incoherence and discord. ${ }^{2}$

This chapter examines these collaborative mechanisms, which were contrived to promote a whole-of-government approach. I commence with a consideration of US government attempts to institutionalize cooperation through programmes within agencies and by empowering individuals. The impact of a less formalized instrument for collaboration - personal relationships - is also assessed. This is followed by a comparison of ideas drawn from academic articles and think-tanks with those devised by the US government. Finally, I discuss an issue that has often been overlooked when analysing the reasons for nation-building failings in Afghanistan - the shortness of staff postings in Afghanistan. By discussing these issues in their totality, a more complete picture emerges of the problems associated with establishing functional mechanisms to overcome bureaucratic hurdles.

\section{Government-Based Mechanisms for Cooperation}

As the disorganization of US nation-building in Afghanistan received increased scrutiny from Congress, the Media and the White House, agencies were 
encouraged to explore mechanisms for facilitating a whole-of-government approach. Ironically, the initiatives that resulted were typically hatched in bureaucratic isolation. The State Department, USAID, the military establishment, the counter-bureaucracy and the National Security Council (NSC) all developed their own solutions to the problems of inter-agency incoherence. But the 'solutions' proffered simply expressed and exacerbated the original problem, as becomes clear when considering a few of the more notable examples.

Arguably, the most promising hub for the promotion of bureaucratic cohesion was the Office of Coordination for Reconstruction and Stabilization (S/CRS). S/ CRS was established in 2004 when the Bush administration became frustrated with the inability of civilian agencies to mobilize and organize nation-building operations in Afghanistan and Iraq. It was mandated to provide streamlined civilian expertise while overcoming the bureaucratic divisions. Positioning the new office within the State Department, however, severely restricted its capacity to influence other agencies and turf-conscious factions within the department itself. Although S/CRS put forward a number of innovative solutions for intragovernmental cooperation - such as the Civilian Response Corps (CRC) and the Country Reconstruction and Stabilization Group - these and other ideas did not transcend the confines of its small office in Washington. Its mandated authority, therefore, was juxtaposed with what Stewart describes as 'a beleaguered, understaffed and under-resourced entity operating from a single government department'. S/CRS lacked power and credibility, which relegated it to 'offering conflict management consultancy services to skeptical regional bureaus'. ${ }^{3}$ In 2007, opposition from within the State Department resulted in the S/CRS administrator being demoted to the position of Deputy Director of Foreign Assistance, which further marginalized the office within the department's 'turf-conscious bureaucracy' ${ }^{4}$ A Senior Defence Department Official explained the regulatory and funding problems associated with its location:

S/CRS turned out not to be very successful, partly because they couldn't get resources from the Hill and partly because they couldn't build up the cadre of folks that they wanted to build up. I think that the reason for these problems was that it was formed in the wrong place. It shouldn't have been at State, it should have been at the White House level. Or, if it had to have been at State, it should have had a direct reporting capability to the White House. The National Security Council and the Office of Management and Budget should

3 Patrick Stewart, "The US Response to Precarious States: Tentative Progress and Remaining Obstacles to Coherence", in Stefani Weiss (ed.), International Responses to Precarious States: A Comparative Analysis of International Strategies with Recommendations for Action by European Institutions and Member States (Washington, DC: Center for Global Development, 2007), 7; Miles, "The State Department, USAID, and the Flawed Mandate for Stabilization and Reconstruction", 40; Stewart and Brown, Greater than the Sum of its Parts?, 39.

4 Bowen, "No More Adhocracies Reforming the Management of Stabilization and Reconstruction Operations". 
have had a stake. A higher level would have helped get resources from the Hill. It just didn't work out of State. The State Department interacted with the Foreign Relations and Foreign Operations Committees and those guys didn't give $\mathrm{S} / \mathrm{CRS}$ a lot of money. ${ }^{5}$

USAID, meanwhile, viewed S/CRS as an attempt by the State Department to overrule its decisions. A Senior USAID Official was candid in his response to such an encroachment: 'I told them to go screw themselves, I don't want them telling me what to do'. In explaining his response he said, 'We didn't want another layer of oversight, because more oversight actually slows everything down - everything, it doesn't improve things' ${ }^{6}$ Although S/CRS had no association with the counter-bureaucracy, USAID asserted its independence where it could. USAID may not have been able to shake off the encroachments of the OMB, State Department or the military establishment, but it easily dismissed the nascent S/CRS.

The military establishment was more accommodating of S/CRS programmes, and indeed can be seen as a supporter. Ambassador John Herbst, the Coordinator for Reconstruction and Stabilization, who headed S/CRS in 2006, claimed that the military establishment was in fact a 'big' supporter of his office. At the request of the Pentagon in 2007, S/CRS put together civil operational plans for US Provincial Reconstruction Teams (PRTs) in Afghanistan. The plan drew a favourable response from the military, all the way up to Defence Secretary Robert Gates and the Chairman of the Joint Chiefs of Staff, Michael Mullen. The reason for the military's support was because PRTs (which we will examine in more detail in the next chapter) were designed as quick-impact units that aligned with COIN. PRTs were successfully implemented when other S/CRS initiatives were not, principally because of the military's involvement. Herbst argued that if the civil operational plans had come from S/CRS alone, the State Department and USAID would have simply dismissed them. Notwithstanding the PRTs and other small projects, nation-building in Afghanistan was too large an operation for $\mathrm{S}$ / CRS to influence. $\mathrm{S} / \mathrm{CRS}$ staff members admitted that the role it played there was minor. $^{7}$

In 2011, S/CRS was replaced by the Bureau for Conflict and Stabilization Operations (CSO). Essentially the same office with a different name, CSO inherited its predecessor's limitations. Again, the most damage occurred with the decision to shackle CSO to the State Department, which crippled the new Bureau's capacity to function autonomously. According to a report by the Commission on Wartime Contracting, stove-piping, and other internal machinations within State, prevented it from gaining 'sufficient authority or bureaucratic heft to enforce accountability'. Ambassador Inderfurth adds that CSO was never well funded nor

5 Author Interview with a Senior Defence Department Official, via telephone, Sydney to Colorado, July $15,2013$.

6 Author Interview with a Senior USAID Official, Washington DC, April 19, 2012.

7 Author interview with a Senior State Department Official, Washington DC, April 30, 2012. 
was it given adequate attention. ${ }^{8}$ Both these enterprising initiatives, therefore, came off second best in the US's bureaucratic turf wars.

Another initiative that attempted to empower the State Department was the National Security Presidential Directive 44 (NSPD-44). In 2005, NSPD-44 made the Secretary of State responsible for coordinating the inter-agency process. The Secretary was directed to lead inter-agency efforts, mitigate conflict between agencies, and develop integrated plans that wedded civilian and military programmes. NSPD-44 was subject to significant delays, however, and failed to impact on nation-building in Afghanistan. According to a report by the US House of Representatives Committee on Armed Services, it provided 'unclear and inconsistent guidance' on agency roles and responsibilities. ${ }^{9}$ The directive, moreover, was disconnected from other inter-agency strategies, such as S/CRS and CSO, and it failed to clarify how the military establishment would support civilian efforts.

After becoming Secretary of State, Condoleezza Rice tried another approach. She highlighted the importance of improving civilian capacity for nation-building and advocated 'Transformational Diplomacy' that would facilitate discussion between US agencies. ${ }^{10}$ Transformational Diplomacy emphasized democracy through development and gave the USAID director full authority to manage the State Department's foreign aid programme. Predictably, USAID supported it, but Rice's commitment to democratic governance through nation-building proved to be neither effective nor long lasting. The strategy suffered from many of the same afflictions as NSPD-44 and was quickly overturned when the Obama Administration came to power. USAID's new powers were usurped by Hillary Clinton's State Department, and the agency's autonomy became compromised when a Deputy Secretary of State was appointed to manage its budget.

USAID fared no better in its relatively insignificant attempts to promote cooperation. The agency's previously mentioned marginalization, which partly resulted from its unique interests and culture, made it less likely that other agencies would embrace its proposals. The Office of budgeting and personnel systems and programming was created to address state fragility and failure. ${ }^{11}$ Similarly, the Office of Military Affairs was created to enhance cooperation with the Pentagon. Realistically, however, they functioned as a loudspeaker for incorporating a particular conception of development into a whole-of-government strategy. Both initiatives were the brainchild of Natsios when he was USAID administrator. ${ }^{12}$

8 Commission on Wartime Contracting, An Urgent Need: Coordinating Reconstruction and Stabilization in Contingency Operations (Washington DC: 2010); Assessment of US Strategy and Operations in Afghanistan and the Way Ahead, Committee on Armed Services, House Of Representatives, One Hundred Tenth Congress Hearing, January 23, 2008, 23.

9 House of Representatives, Agency Stovepipes vs. Strategic Agility: Lessons We Need to Learn from Provincial Reconstruction Teams in Iraq and Afghanistan, United States House of Representatives Committee on Armed Services, Subcommittee on Oversight \& Investigations, April 2008, 41.

10 "Bush a Convert to Nation-building", Washington Times, April 7, 2008.

11 Natsios, "USAID in the Post-Cold War World", 21.

12 Natsios, The Clash of the Counter-Bureaucracy and Development, 43. 
Each of them made perfect sense from his standpoint, but their narrow developmental premise was antithetical to the interests of the rest of the US government. More generally, while USAID believed its voice resonated with experience and skill, officials at the Pentagon and State Department perceived the agency's proposals to be unrealistic and inappropriate. ${ }^{13}$

Meanwhile, the military's mechanisms for cooperation revolved around warping the agenda of other agencies to suit its interest in counter-insurgency. The 2004 Counter-insurgency Strategy for Afghanistan was hailed by its advocates as 'a powerful tool for explaining the basics of our strategy to civilians'. It was 'circulated down to the very lowest tactical levels' in the hope of facilitating both inter- and intra-agency cohesion. ${ }^{14}$ The more frequently cited Counter Insurgency Doctrine (COIN) was described by Lieutenant Colonel John Nagal as promoting 'economic development, good governance, and the provision of essential services, all occurring within a matrix of effective information operations'. According to a new breed of military leadership, led by David Petraeus and Stanley McChrystal, this mantra 'displaced fire and maneuver atop the pyramid of soldierly priorities'. ${ }^{15}$ Petraeus, in particular, was credited with successfully applying COIN Iraq, and his counter-insurgency-based solutions were embraced by the military establishment in Afghanistan as a panacea for agency divisions within the US nationbuilding mission.

The wealth of resources and manpower at the disposal of the military establishment, however, did not ensure a better chance of success. ${ }^{16}$ It failed to balance the interests and cultures of the various agencies involved in nation-building, nor was the COIN strategy as well funded as the comparable effort in Iraq. While the United States Army Field Manual 3-24 made brief allusions to inter-governmental cooperation, it encouraged military forces to perform tasks traditionally allocated to civilian agencies, the consequence of which was to drive a wedge between the military and civilian agencies.

Programmes such as CERP, the PRT's J-10 and Army Civil Affairs Teams buttressed the military's interests in counter-insurgency, rather than incorporating counter-insurgency into complementing a wider nation-building strategy that blended military resources with civilian expertise. The ability of these programmes to operate outside the counter-insurgency bubble relied on the military commander's ability to overcome embedded cultural norms. But more often than not military commanders were unable to divorce themselves from preconceived perceptions about nation-building that permeated the military. This may explain why some US Army Civil Affairs Teams were considered 'refreshingly enterprising and practical',

13 Author Interview with a Senior Defence Department Official, via telephone, Sydney to Colorado, July 15, 2013.

14 Barno, "Fighting 'The Other War'”, 34.

15 John Nagal, Counterinsurgency Field Manual (Chicago: University of Chicago Press, 2007), xix; Bacevich, Washington Rules, 188.

16 Thomas Ricks, The Gamble: General Petraeus and the American Military Adventure in Iraq (London: Penguin, 2009). 
while most were marked as ineffective. ${ }^{17}$ Other initiatives by the military seemed to be platitudes that proved to Washington that it was providing an inter-agency platform. The Civilian Management Crisis Corps, Joint Coordination Groups, Combatant Commanders Integrated Collaboration Team, the Government Counterinsurgency Guide and the Center for Complex Operations, were neglected or ignored. Meanwhile, the State Department's major attempt to embrace COIN, the Government Counterinsurgency Guide, reached across various government agencies, creating a set of broad principles for nation-building. Yet the guide, Cohen states, 'languished in relative obscurity with little apparent impact on interagency planning, strategy, or operations in Iraq and Afghanistan or elsewhere'. ${ }^{18}$

While agencies claimed to support the Center for Complex Operations, attempts to disseminate data were stifled by the bureaucracy. Indeed, the various agencies involved struggled even to fulfil requirements 'for sharing personal data, protecting the identity of the personnel who provide information, competing claims on the ownership of the information itself, and appropriately using and disseminating interview data' ${ }^{19}$ The Center's move from the DoD to the National Defence University in less than a year signified the minimal impact it had had on influencing nation-building operations.

Solutions were also proffered by fiscally minded officials in Washington, who perceived the State Department to be the most suitable agency to allocate, manage and monitor nation-building enterprises. Those who filled the ranks of the Wartime Contracting opined that, 'without good planning, visibility, and coordination among agencies and nations, the risk of waste, unwanted duplication or unsustainable projects is high' ${ }^{20}$ The Office of Foreign Assistance (OFA) was formed to track, classify and monitor foreign assistance, but as it was jointly managed by the State Department and USAID, it developed close to 1,000 complex and confusing indicators for such a purpose. The OFA was criticized for adding a new layer of obfuscation similar to that created by the OMB. From the perspective of many US developmental professionals, State officials and military commanders, instead of streamlining operations it had had the opposite effect. ${ }^{21}$

Similar ideas did not go beyond the planning stages. Stuart Bowen, the former Special Inspector General for Iraq Reconstruction (SIGIR), advocated the creation of a US Office for Contingency Operations (UOCO) to oversee nation-building and allow 'many of the lessons learned from Iraq and Afghanistan to be applied vigorously'. He offered UOCO as an 'executive authority below the President to ensure the effectiveness of contingency relief and reconstruction operations',

17 Chayes, The Punishment of Virtue, 150.

18 Raphael Cohen, “A Tale of Two Manuals", PRISM, 2:1 (2010), 87.

19 Melanne Civic and Bernard Carreau, "Building a Civilian Lessons Learned System", PRISM, 1:2 (2010), 138-139.

20 Commission on Wartime Contracting, An Urgent Need: Coordinating Reconstruction and Stabilization in Contingency Operations, 3-5.

21 Natsios, "The Clash of the Counter-Bureaucracy and Development", 33; Author Interview with a Senior Defence Department Official, Washington DC April 18, 2012. 
which would avoid waste and provide 'effective oversight through audits and investigations of all funds'. However even the fundamental question of UOCO's location could not be determined. National Security Council Advisor Brent Scowcroft claimed that UOCO should be independent; Dobbins said it should be placed within USAID; and former US Central Command General Anthony Zinni wanted it stationed within the DoD. None, however, wanted UOCO to be run through the OMB. ${ }^{22}$ This lack of agreement, underpinned by the incompatible interests of the various officials, determined that the UOCO never effectively performed the functions for which it was intended.

Finally, collaboration was encouraged by the National Security Council (NSC). Since it was created in 1947 by President Truman, the NSC has been utilized on an ad hoc basis. Fashioned to advise the President on how best to integrate domestic, foreign, and military policies relating to national security, the NSC is considered by some to be the most powerful committee in the world. That power is often able to breach institutional barriers and facilitate inter-agency cooperation. But it is as famous for its failures as it has been for its successes. The officials who make up the NSC, moreover, all carry the baggage of interests, perceptions and agency culture to the negotiating table, which compromise their ability to transcend parochial boundaries and construct a whole-of-government response. ${ }^{23}$

The NSC was hugely influential in determining the shape and nature of the GWOT, but less involved in organizing agencies for nation-building in Afghanistan. Nonetheless, in March 2007, the NSC-initiated Interagency Management System (IMS) was created in coordination with S/CRS to 'provide policy-makers in Washington, Chiefs of Mission, and military commanders with flexible tools to achieve integrated planning processes for unified US government strategic and implementation plans, including: funding requests, joint-interagency field deployment, and a joint civilian operations capacity'. ${ }^{24}$ It included the Advanced Civilian Teams and Integration Planning Cell. As these initiatives were implemented by S/CRS rather than the NSC itself, however, they had little impact on the behaviour of the foreign policy bureaucracy. Furthermore, the IMS was ignored by the Pentagon, most likely because it did not include a military representative as a cochair. The lack of attention devoted by NSC to Afghanistan meant that it played a relatively minor role in nation-building. ${ }^{25}$

22 Bowen, "No More Adhocracies: Reforming the Management of Stabilization and Reconstruction Operations", 3-42.

23 Karl Inderfurth and Loch Johnson (eds), Fateful Decisions, Inside the National Security Council (New York: Oxford University Press, 2004); Roger George and Harvey Rishikof (eds), The National Security Enterprise, Navigating the Labyrinth (Washington DC: Georgetown University Press, 2011).

24 Department of State Archive, Frequently Asked Questions About the Office of the Coordinator for Reconstruction and Stabilization, July 15, 2008, http://2001-2009.state.gov/s/crs/66427.htm (accessed 20/4/2013).

25 Commission on Wartime Contracting, An Urgent Need: Coordinating Reconstruction and Stabilization in Contingency Operations, 11; Dan Caldwell, Vortex of Conflict: US Policy Toward Afghanistan, Pakistan and Iraq (Stanford University Press: California, 2011), 187-207. 


\section{Individuals as a Conduit for Cooperation}

The other approach for overcoming inter-agency obstacles to nation-building programmes involved the empowerment of particular individuals. The Afghanistan Freedom and Security Support Act, 2007, adopted by the US House of Representatives, was offered by Congress as a solution to Afghanistan's much publicized drug problem. The act presented a coordinated US counter-narcotics strategy, but had more general implications for the nation-building mission. It required the President to appoint 'a coordinator' whose duty was 'to work across all United States government departments and agencies'. This coordinator was to ensure 'interagency policy coordination on assistance and counter-narcotics activities', by resolving inter-agency disputes and 'coordinating interagency implementation and oversight assistance' ${ }^{26}$

But the empowerment of some sort of inter-agency overseer was also fraught with problems. It failed to consider where the coordinator would have come from the civilian or military realm - or what authority the position would have had with respect to various agencies and their respective leaders. Prima facie, there did not seem to be any means of compelling any of the agencies to obey this mysterious figure. The 'counter-narcotics chief' would have been simply another layer of bureaucracy that added to an already confusing network of competing hierarchies. A senior State Department official lambasts the suggestion as 'a pipe dream':

You are asking for a second President. I'm very skeptical. We don't coordinate well, but is the coordinator going to be able to order the resources of the Secretary of Defence and Secretary of State? Are they going to roll over and say yes sir? Dubious. And then when you try to apply it to the Afghan experience it's total bull and ignores the huge systemic barriers.

Other congressional attempts to apply new strands of authority to Afghanistan were similarly delusional, because they failed to understand the human element or how individuals interact with the bureaucratic machine. ${ }^{27}$ Congress's distance from and inexperience of the bureaucratic machine that oversaw nation-building in Afghanistan predisposed it to provide simplistic solutions to complex problems. In so doing, its 'solutions' were typically abject failures.

While Congress's plans never came to fruition, a White House plan for a new position of authority did see the light of day. In January 2009, career diplomat and international statesman Richard Holbrooke was appointed as the US Special Envoy to Pakistan and Afghanistan. He thereby gained nominal authority over the US mission. Placed outside of the direct chain of command, Holbrooke derived his authority from new President Barack Obama, and was mandated with

26 Afghanistan Freedom and Security Support Act of 2007, May 30, 2007, Report 110-170, Section 106.

27 Author Interview with a Senior State Department Official, Washington DC, April 18, 2012. 
the power to act on his behalf. His position was similar to that which Nelson Rockefeller had proposed in 1960 when he had called for a 'First Secretary of the Government'. Holbrooke's position, however, was exclusively to deal with the problems of nation-building in Afghanistan. He would be 'a special agent who does not have commitments to a particular bureaucratic organization and is free to cut across the concerns of various departments', ${ }^{28}$ The position that he would occupy would elevate 'one official above factious departments', as Destler puts it. Nevertheless, it would also create 'a welter of internal political problems for those above him and those below, even if the job he is supposed to do clearly needs doing'. Wilson claims that this is due to the fact that 'our form of government, to say nothing of our political culture, does not lend itself to czars' ${ }^{29}$

Before accepting the position, Holbrooke was a prominent figure within the State Department and the US Democratic Party. His Foreign Policy article 'The Machine That Fails', displayed an acute awareness of how bureaucratic problems can prevent the US government from uniting behind an agreed plan..$^{30}$ Decades later, one of Holbrooke's staff argued that he still understood the 'daunting complexity of Washington'. He also recognized the long-term implications of the conflict in Afghanistan before others within the US government. He claimed that it would be 'far more costly and much, much longer than Americans realize . . . This war, already in its seventh year, will eventually become the longest in American history'. ${ }^{31}$

Holbrooke - who was praised as an exemplary civil servant, skilled statesman and 'a model for aspiring diplomats' - stepped into the breach with typical vigour, ready to implement immediate reforms. He appointed young officials who were comparable with McNamara's 'whiz kids' or those whom Bundy and Kissinger recruited to the White House. These and others members of his team compared their office to an Internet start-up, where each person was treated as an equal partner. ${ }^{32}$ Such a new and innovative approach, however, was not welcomed within the State Department, which had deep cultural traditions and established hierarchies that resisted Holbrooke's innovations.

Factions within State resented what they viewed as his somewhat arbitrary appointments, because they circumvented established procedural norms. Many State Department officials, moreover, were confused as to whether the US Embassy in Afghanistan was under the control of Holbrooke and his team or the US Ambassador. An additional problem was that he only had budget authority

28 Morton Halperin, Bureaucratic Politics and Foreign Policy (Washington DC: The Brookings Institution, 1974, 287).

29 Destler, Presidents, Bureaucrats and Foreign Policy, 26 and 39; Wilson, Bureaucracy, What Government Agencies Do and Why They Do It, 272.

30 Holbrooke, "The Machine That Fails".

31 David Rohde, "Richard Holbrooke's Last Mission in Afghanistan", The Daily Beast, November 26, 2011; George Packer, "The Last Mission: Richard Holbrooke's Plan to Avoid the Mistakes of Vietnam and Afghanistan", The New Yorker, September 28, 2009.

32 David Rohde, "The Lost Mission", in Derek Challet and Samantha Power, The Unquiet American (New York: Perseus Books, 2011), 282-296. 
over State and USAID funds, which left almost half of US foreign assistance outside of his purview. ${ }^{33}$

Holbrooke's attitude only fortified bureaucratic resistance and 'his rivals in Washington looked for the slightest indication of his famed ego or misbehaviour'. He had a reputation for competitiveness and speaking out against perceived threats. Even Hillary Clinton, his ardent supporter, acknowledged Holbrooke's 'flair for the dramatic'. He was perceived by others to be bullying, abrasive, ego-centric and confrontational, which found expression in the nickname of 'Bulldozer'. All of these characteristics compounded to form a problematic personality, which alienated many of those around him, so that his 'enemies nearly outnumbered his friends'. ${ }^{34}$ Douglas Lute, the White House 'war czar', for example, shared Holbrooke's opinion on the need to 'fix' US nation-building in Afghanistan, but personal animosity prevented the two from cooperating: 'Lute found Holbrooke too much of a block on creative thinking, while Holbrooke thought Lute's ideas were not grounded in reality', a Washington official observed. ${ }^{35}$

The twin issues of position and personality combined to alienate many personnel in USAID, who resented the contrarian policies emanating from Holbrooke's office. He railed against USAID officials and soldiers engaged in programmes that failed to involve local actors, believing that these programmes created a 'destructive dependency . . . that delegitimizes local government' ${ }^{36}$ As a result, his policies were viewed by USAID officials as arbitrary, capricious and exclusionary, and Holbrooke's staff were dismissed as having no knowledge of development practices. Holbrooke's chief of staff, for example, had no diplomatic or developmental experience, while others were young and untested. Overall, USAID believed that Holbrooke's policies would be disastrous for development in Afghanistan.

In particular, USAID Director Andrew Natsios considered Holbrooke's agricultural policies, 'illegal, stupid from a developmental standpoint and a massive waste of money'. Dubbed 'farmer Holbrooke' by Hillary Clinton, due to his intense interest in US agricultural projects in Afghanistan, he increased funding to the Pushtun areas in the South and East by 80 per cent, which was perceived by one USAID official as a political stunt: 'how can you spend 2 billion dollars for 2 million people in remote areas who don't want to be developed? ${ }^{37}$ According to

33 Jodi Kandor, "Hoolbrooke: A Larger Than Life Statesman", World Security Network, February 19, 2009, http://www.worldsecuritynetwork.com/United-States-Afghanistan/Kantor-Jodi/HolbrookeA-larger-than-life-statesman (accessed 22/05/2013); Stewart and Brown, Greater than the Sum of its Parts?, 52.

34 Packer, "The Last Mission: Richard Holbrooke's Plan to Avoid the Mistakes of Vietnam and Afghanistan"; Hillary Clinton, Remarks at the Launch of the Asia Society's Series of Richard C. Holbrooke Memorial Addresses, New York, February 18, 2010; "Richard Holbrooke, Bullish and Bullying: The Rise of an American Diplomat", The Economist, December 3, 2011”.

35 Julian Borger, "New Direction for US in Afghanistan Following Richard Holbrooke Death", The Guardian, December 15, 2010.

36 Rohde, "Richard Holbrooke's Last Mission in Afghanistan".

37 Author Interview with a Senior USAID Official, Washington DC, April 19, 2012. 
Chandrasekaran, Holbrooke provided a 'tsunami of money' for agriculture in Helmand even though the funds were not sustainable. As a result, teachers in Nawa stopped showing up to schools, because digging ditches for agriculture projects paid more money. Animosity between USAID and Holbrooke's staff reached such heights that there was purportedly a physical fistfight between Holbrooke and a senior USAID official. The proposition that his personality spurred such conflict is supported by the fate of his successor, Mark Grossman, who developed a rapport with USAID and assuaged their past grievances. ${ }^{38}$

Holbrooke's appointment was also resented by many at the military establishment, and his staff had difficulty convincing more seasoned Pentagon officials of the merit of their plans. He opposed the military surge and was deeply sceptical about the suitability of the NATO campaign in Afghanistan. Instead, he advocated a peace deal with the Taliban. Vali Nasr, a member of Holbrooke's staff, claimed that 'he understood from his experience that every conflict has to end at the negotiating table'. ${ }^{39}$ With this in mind, his team secretly engaged in talks with prominent figures linked to the Taliban, outside of official diplomatic channels.

To make matters worse, Holbrooke was more than willing to point out the power asymmetry between the civilian and military realms. When he was described as the civilian counterpart to General David Petraeus, for example, he laughed and quipped that 'he has more airplanes than I have telephones'. On another occasion, Holbrooke exclaimed to the media that he was bemused at the juxtaposition of his arrival to a 2010 meeting in a taxi with that of Petraeus, by then the Commander of the Combined Forces in Afghanistan, who was escorted by a battalion of aides. During the meeting he flinched when Petraeus referred to him as his 'wingman'. While the military commander may have meant this as a compliment, Hoolbrooke perceived it as inferring that the civilian side of the US government was simply an adjunct to the military establishment, even in the realm of diplomacy. ${ }^{40}$ Additionally, he was quoted as saying that Karzai was impossible to work with, which drew further ire from the military. As one of McChrystal's aides remarked, his errant behaviour 'undercuts our ability to work with him'. McChrystal's team also described the Special Envoy as 'a wounded animal; terrified of losing his job, ready to lash out and screw up the entire plan' ${ }^{41}$ Gates and Petraeus, who continued to move forward with the counter-insurgency drive regardless, interpreted Holbrooke's behaviour as seditious and damaging, allegedly calling for his removal. Although Clinton supported the military's strategy, she continued to protect him out of respect for his loyalty to her during the presidential primary

38 Rajiv Chandrasekaran, Little America: The War Within the War for Afghanistan (London: Vintage, 2013); Author Interview with a Senior USAID Official, Washington DC, April 19, 2012.

39 Nicholas Kristof, "What Holbrooke Knew”, New York Times, May 14, 2001.

40 Packer, "The Last Mission: Richard Holbrooke's Plan to Avoid the Mistakes of Vietnam and Afghanistan".

41 Michael Hastings, The Operators, The Wild and Terrifying Inside Story of America's War in Afghanistan (London: Orion Books, 2012), 5-34. 
campaign. Holbrooke's tragic death during a meeting in December 2010 put a premature end to a brilliant, but controversial, diplomatic career.

An examination of Holbrooke's role in Afghanistan points to the importance of relationship-building. Lieutenant General Frank Kearney, a former Deputy Commander of US Special Operations Command, went so far as to say that 'it's about trust and relationships. It has nothing to do with knowledge'. In the field, US officials, both military and civilian, considered outside-the-box thinking beneficial, and observed that certain personalities were better adapted to the unprecedented situations that arose in nation-building. ${ }^{42}$ This is borne out when comparing and contrasting the relationships between different combinations of US Ambassadors and Commanders of the Combined Forces in Afghanistan.

In late 2003, the appointment of David Barno and Zalmay Khalilzad to the posts of US Commander of the Armed forces and US Ambassador respectively, was emblematic of an enhanced US commitment in Afghanistan. Both men recognized the need to do something to buttress the US mission though a realignment of tactics and resources, a large part of which involved the promotion of better relations within the US government. Barno insisted that change must emanate from senior staff, who 'have got to ask those hard questions and have got to dig to get to the answers and not take the pabulum that's going to be pushed up by the bureaucracy'. In achieving this, relationships were,

... hugely important in bridging divisions. You can have all the doctrine, rules, procedures and processes in the world, but if the two people in charge of the two elements of policy don't get along, none of these are going to work or make any difference.

When senior figures develop a fraternal relationship, he argues, bureaucratic obstacles and inertia can be overcome. Barno applied this thinking to forge a strong bond with Khalilzad that helped bind the civilian and military realms together. Both men realized that personality matters and that their personal relationship would 'set the tone for embassy and military teams across Afghanistan' ${ }^{43}$ The rapport they cultivated was considered by senior US officials from a number of different agencies to be unequivocally beneficial to the nation-building mission. ${ }^{44}$ With Barno at the helm, the military often stepped outside the confines of a war-fighting role. While military forces continued to be the largest US presence in Afghanistan, Khalilzad and Barno's relationship encouraged a more level playing field. Common policy objectives and a joint deployment of resources ensured that the military, at least in the field, used its vastly superior resources to augment civilian capacity. The Embassy Interagency Planning Group was created to funnel military assets into under-resourced sections of the US Embassy, and to provide teams of strategic planners and military officers to supplement civilian offices in

42 Markel et al., Developing US Army Officers', 30-34.

43 Author Interview with a US Military Commander, Washington DC, April 29, 2012.

44 This was confirmed during interviews with a number of US officials. 
Kabul. Unlike previous efforts, which had involved 'pulling the rope in different directions, one team was using resources for the overall policy effort'. According to Lloyd Austin, the Commander of Combined Joint Task Force, Barno and Khalilzad were 'very close' and 'complemented each other'. 'I'm not sure they could have worked better together', he avers. ${ }^{45}$

Small and seemingly obvious changes were applied that had eluded their predecessors. Barno stood down the three-star headquarters in Bagram and re-erected it in Kabul. He and Khalilzad had adjacent offices and both resided at the Embassy compound: 'I had an office twenty feet from his office', Barno states. The Ambassador and Commander were in constant communication and country-team and core security group meetings were held daily, where they 'very much saw each other as an interagency team' ${ }^{46}$ The duo attended over 300 country team meetings, which included senior officials from the State Department, USAID, the DoD and the Armed Forces. David Lamm, Barno's chief of staff, recalls a 'tight knit' community, which presented Afghan President Hamid Karzai and his Cabinet with a united governmental front and prevented those Machiavellian Afghan politicians from exploiting divergent agency cultures in Afghanistan. One military official who served under them noted that the military's command apparatus became fully integrated with the US Embassy, which meant that no cable left the Embassy without review or comment from the military. As Crocker and Petraeus did with Iraqi Prime Minister Nouri al-Maliki, Barno and Khalilzad almost always saw Karzai together. When they did meet with him alone they briefed each other before and after. When conflict erupted between two rival powerbrokers in Herat, Barno and Khalilzad synchronized a combined military and diplomatic response to prevent hostilities from intensifying. ${ }^{47}$

To augment their harmonious relationship, Khalilzad's reputation in Washington streamlined funding. Moulded from the same intellectual and philosophical bent as prominent figures within the Bush administration, he used personal connections to obtain funding for the nation-building mission in Afghanistan. The Ambassador was often able to influence normally reticent officials, such as Donald Rumsfeld, to overcome governmental hurdles and work outside of the formal institutional structures. When combined with a united military/civilian front, this helped Khalilzad and Barno to raise US assistance to \$2.2 billion in 2004. Upon finishing their tours of duty the two men expressed satisfaction and believed a 'close personal relationship . . . cemented the unity of our effort' and paid 'immense dividends'. ${ }^{4}$

45 Barno, "Fighting "The Other War", Counter-insurgency Strategy in Afghanistan, 2003-2005", 37; Author Interview with General Barno; Yodsampa, No One in Charge, 146.

46 Christopher N. Koontz, Enduring Voices: Oral Histories of the US Army Experience in Afghanistan 2003-2005 (Washington DC: Center of Military History, 2008), 23; Author Interview with a US Military Commander, Washington DC, April 29, 2012.

47 Yodsampa, No One in Charge, 157; Jason Motlagh, “\$5 Billion For Afghans Still Unspent”, Washington Times, March 25, 2009.

48 Dobbins, After the Taliban: Nation-Building in Afghanistan; Barno, "Fighting "The Other War", 37. 
But following their departure the bureaucracy regained its natural rhythm. While relations between Barno and Khalilzad's successors, Karl Eikenberry and Ronald Neumann were not openly hostile, each retained separate spheres of authority. Neumann acknowledged that the cumbersome bureaucracy needed to be challenged by 'a person who really wants to make decisions'. ${ }^{49}$ Neumann, however, was unable to influence Eikenberry to adopt a similar attitude. A senior military official observed that inter-agency relations deteriorated under their partnership and that much progress was lost: Eikenberry 'put new fingerprints [on the mission] and changed things right away'. The Commander of the Armed Forces immediately moved his operational headquarters from the Embassy at Kabul back to Bagram airbase, and appointed a deputy to represent him in Kabul. Additionally, both the Interagency Planning Group and the Interagency Resources Cell were marginalized and then phased out. This represented a startling shift, which unshackled the military from the rest of the government and, as Colonel Lamm said, fostered the impression that 'the US military was going its own way': 'Eikenberry didn't seem to want to spend as much time at the Embassy', one State Department official said, while another noted that there was 'a bad relationship between Eikenberry and everybody who wasn't wearing a green uniform'. ${ }^{50}$

Each man had strong opinions about the various aspects of nation-building, but although there was a common understanding that their jurisdictions overlapped, rarely did they pursue common goals together. Realistically, cooperation between Neumann and Eikenberry was never more than 'strong discussions on either side of the fence', which often resulted in a 'refusal to reach agreement' ${ }^{51}$ Personality prevented the two from taking steps to surmount systemic obstacles by forging an informal bond. Although neither man actively set out to erect barriers between the civilian and military realms, their reversion to standard practices and procedures meant that those barriers were re-erected. Eikenberry, especially, was keenly aware of his agency's interests in Afghanistan as the insurgency intensified. He considered the US mission in Afghanistan to revolve around 'the defeat of al Qaeda and their Taliban militant allies' and to prevent international terrorism from finding 'support and sanctuary' within the country's borders. He often referred to State Department officials as his 'teammates', but that team was not wearing the same coloured jerseys. ${ }^{52}$

Instead, Eikenberry approached policy separately from Neumann who had a different opinion on operational military strategy and other matters. Eikenberry had an obsession with one aspect of reconstruction: roads. He was convinced that 'where the roads ended the insurgency begins'. This resulted in almost 70 per cent of CERP funding being directed to road building projects. One senior

49 Interview with Jim Webb, PRISM, 1:2 (2010); Author Interview with Ronald Neumann.

50 Motlagh, "\$5 Billion in Afghanistan still Unspent”; Yodsampa, No One in Charge, 214-216.

51 Author Interview with a Senior State Department Official, Washington DC, April 18, 2012.

52 Committee on Armed Services, Assessment of Security and Stability in Afghanistan and Development in US Strategy and Operations, 5. 
military official revealed that this far exceeded the capacity of the Army Corps of Engineers, and resulted in an 18-month backlog. As he continued to prioritize roads, Eikenberry's relationship with USAID's acting administrator James Kunder became strained. For example, he remarked before a House Armed Service Committee meeting that roads had created better access to markets and more income for Afghan farmers. This was disputed by Kunder who said that roads did not help farmers as no sufficient markets had been developed for them to sell their goods. Neumann and Eikenberry's relationship is comparable to that of Dan McNeil, the Commander of the Combined Forces from 2002 to 2003, and Robert Finn, the US Ambassador at the time. When McNeil arrived and proposed a cooperative partnership, Finn informed him that he [McNeil] was there to fight a war: 'If we collaborated on anything that looked like US policy other than building the ANA, I can't recall it', McNeil remembers. ${ }^{53}$

Eikenberry's role in Afghanistan was not finished when he stepped down as Commander of the Armed Forces. Following the disastrous appointment of William Wood, he returned to the country as US Ambassador. He was partnered with Stanley McChrystal, a close associate of David Petraeus, the aforementioned brains behind the surge in Iraq. McChrystal's appointment had its own controversies, which centred on the abrupt dismissal of his predecessor, David McKiernan.

A meeting in March 2009 with Admiral Michael Mullen, the Chairman of the Joint Chiefs, and Gates was claimed to be the catalyst for McKiernan's sacking. One military official, however, disagreed. He said that Gates and Mullen's decision was based on his personality: 'he wasn't high energy . . . McKiernan had some of the right concepts, but he didn't have the creativity and energy'. There seemed to be no other reason for McKiernan's fall from grace. Strategically, politically and diplomatically he made no errors. Indeed, suggestions that he was slow to adapt and failed to understand the counter-insurgency drive was considered by another senior military official to be 'laughable'. 'McKiernan did his best - he was just the wrong guy', added military analyst Ralph Peters. ${ }^{54}$

Gates's justification for 'fresh eyes' and 'fresh thinking', was based on a political and personal rationalization. He and Mullen wished for more favourable media headlines in addition to which McChrystal was well liked by David Petraeus, the mastermind behind the counter-insurgency strategy. Although Petraeus was absent when Gates and Mullen 'wielded the knife', it was no secret that he and McKiernan did not get along and he most likely played a part in the decision. ${ }^{55}$ 'The issue', Hastings observed, 'was not ability but rather likability, and being connected to the right people . . . it's bureaucratic infighting and office politics' ${ }^{56}$

53 Motlagh, "\$5 Billion For Afghans Still Unspent”; Yodsampa, No One in Charge, 99.

54 Hastings, The Operators; Mark Thompson, "Why the Pentagon Axed its Afghanistan Warlord", Time, May 12, 2009.

55 Ann Tyson, "General David McKiernan Ousted as Top US Commander in Afghanistan, Washington Post, May 12, 2009; Simon Tisdall, "The Curious Sacking of Gen. McKiernan”, The Guardian, May 13, 2009.

56 Hastings, The Operators, 34-39. 
That, combined with his Special Forces pedigree, made him the 'right man' to spearhead COIN in Afghanistan.

It was expected that Eikenberry and McChrystal could re-create the partnership that Petraeus and Ambassador Ryan C. Crocker had leading the mission in Iraq. In August 2009, they implemented the Integrated Civil-Military Campaign Plan (ICCP) - ironically, almost a carbon copy of the mechanism devised by Barno and Khalilzad, which Eikenberry had removed during his time as Commander of the Combined Forces. The ICCP attempted to develop a model for civil-military relations. Through that initiative and other methods, 'I think that both of us are very proud of the degree of civil-military integration we've been able to achieve', Eikenberry asserted. ${ }^{57}$ But this was misleading. The two men did not get along and their relationship was marked by controversy and conflict.

Eikenberry was far from the career diplomat that his predecessors Khalilzad and Neumann had been. Rather, he was a prominent figure in the competitive military establishment, and thus found it difficult to adapt to the set of interests and culture that he was confronted with at the State Department. Placed opposite him was a similarly ambitious military counterpart, McChrystal, who had a particular perception of how the military's interests were best served. Tensions between the two had previously become evident in Afghanistan. In 2005, one of McChrystal's task forces angered Eikenberry. This resulted in McChrystal and Eikenberry exchanging heated words that expressed mutual mistrust. State Department and military officials found that this led to 'unnecessary clashes and battles of ego': 'You have two generals of similar rank who don't agree on the policy, who apparently don't like each other. It makes for a difficult relationship', remarked Deputy UN Special Representative for Afghanistan, Robert Galbraith. Crocker advised at the time that 'they need to resolve any differences among themselves or take it back to Washington because the stakes in Afghanistan are too great not to have a unified effort' ${ }^{58}$

Yet his advice went unheeded and the two men attempted to do all they could to prevent each other's plans from coming to fruition. McChrystal's platform for nation-building rested on a counter-insurgency drive and the rapid deployment of additional troops. He overhauled the US war strategy, but much of the legacy he was undoing was Eikenberry's. According to government sources at the time, Eikenberry 'can't stand that his former subordinate is now calling the shots'. In November he contributed to the policy debate through two reports in which he argued against McChrystal's counter-insurgency strategy: 'Sending additional forces will delay the day when Afghans will take over, and make it difficult, if not impossible, to bring our people home on a reasonable timetable', Eikenberry

57 Joshua Partlow, "Tensions Between Eikenberry, McChrystal will be Focus of their Washington Visit", Washington Post, May 9, 2010.

58 Marc Ambinder, "The Night Beat: What the Heck Was McChrystal Thinking?", The Atlantic, June 21, 2010. Partlow, "Tensions Between Eikenberry, McChrystal will be Focus of their Washington Visit". 
wrote. It was no surprise, therefore, that when Eikenberry sought the role of NATO's senior civilian representative, in addition to Ambassador, McChrystal recommended against it. Eikenberry was furious that McChrystal refused to support him and many considered it to be 'a move that effectively increased McChrystal's influence over diplomacy by shutting out a powerful rival'. Meanwhile, Karzai exploited their troubled relationship by forging a close bond with McChrystal while ignoring Eikenberry. ${ }^{59}$

Matters worsened when diplomatic cables were leaked to the New York Times. This correspondence derided McChrystal's counter-insurgency plan and revealed that Eikenberry believed the mission in Afghanistan 'cannot be won by military means'. Deploying additional US soldiers involved 'astronomical costs', tens of billions of dollars, he stated on one of those cables: 'We will become more deeply engaged here with no way to extricate ourselves, short of allowing the country to descend again into lawlessness and chaos' ${ }^{60}$

In a subsequent House Armed Services Committee Hearing, Eikenberry expressed full support for McChrystal and the move to send extra troops, stating that he was 'unequivocally in support of this mission' and was 'moving forward now to vigorously implement the assigned mission'. During the hearing the two described themselves as 'old friends'. But their appearance before Congress, 'was one of the most awkward in recent years', according to one observer. ${ }^{61}$ Following the hearing, Embassy spokeswoman, Caitlin M. Hayden, claimed that the Ambassador and military commander were united in their approach to Afghanistan. But McChrystal's staff members were particularly irked by the fact that they were not made aware of Eikenberry's position before he sent the cables. McChrystal himself blamed Eikenberry for 'betraying' him by subversively attempting to influence policy by leaking information. ${ }^{62}$ These and other revelations of intergovernmental disunity were uncovered in an article in Rolling Stone magazine, which resulted in McChrystal's resignation, thus ending a dramatic relationship more befitting of soap opera than the management of US foreign policy.

\section{Non-Governmental Ideas on Inter-Agency Collaboration in Afghanistan}

An interest in promoting intra-governmental collaboration was not restricted to the US government. Spurred on by the GWOT, academics and think-tanks put forward their own models. Some dismissed official attempts to assuage inter-agency

59 Michael Hastings, “The Runaway General”, Rolling Stone, June 22, 2010; Nicholas Graham, "Karl Eikenberry Papers: US Afghan Ambassador's Report Warned Against Troop Escalation", Huffingtonpost, April 5, 2010.

60 Eric Schmitt, "US Envoy's Cables Show Worries on Afghan Plans", New York Times, January 25, 2010.

61 Ewen Macaskill, "McChrystal and Eikenberry Present United Front After Troop Surge Row", The Guardian, December 9, 2009.

62 Ambinder, "The Night Beat: What the Heck Was McChrystal Thinking?" 
tensions because of the gulf between rhetoric and action, while others argued that government-based solutions failed to acknowledge the divergent interests of the agencies involved. ${ }^{63}$ Solutions to overcome these and other problems stemmed from a variety of sources, and ranged from the theoretical to the practical. Often drawn from literature that focused on best practice in corporations, a disparate collection of terms was applied to produce a lexicon for collaboration during nation-building. This included 'harmonization', 'coherence', 'policy integration', 'synergistic engagement', 'whole-of-government approaches', 'team-building', 'multi-sectorial strategies', 'unity of effort', '3-D (Development, Diplomacy, and Defence) approaches', 'strategic planning', 'resource mobilization', 'maintaining workable relations', 'unified leadership' and 'common accountability frameworks'.

Some commentators considered a change in methodology pivotal for US agencies to 'improve the way their efforts link up and support peace'. They argued that planning and execution mechanisms were outdated and required major revision, and that shared objectives promoted unity. ${ }^{64}$ Broad themes such as harmony, understanding and trust were identified as cornerstones for cooperation. Stewart, for example, maintained that a lack of coherence could be addressed through the promotion of harmony within government. However, he promoted the same maxims as the US bureaucrats he criticized, such as 'Clarify Interagency Roles and Coordination in Washington and in the Field', 'Agree on a Common Strategic Vision' and 'Improve Civil-Military Planning and Coordination' ${ }^{65}$ Baumann, who dismissed the viability of a cure-all, nonetheless suggested a strategy focused on the need for 'mutual understanding of the different meanings that different organizations attach to commonly employed terms' in order 'to integrate an understanding of cultural differences' ${ }^{66}$ A number of other commentators insisted that fostering trust was the key to unlocking intra-governmental collaboration. ${ }^{67}$

Some suggestions involved comparative analysis. Orton and Lamb, for example, created ten overarching principles that included 'team empowerment', 'team

63 Andrea Baumann, "Clash of Organizational Cultures? The Challenge of Integrating Civilian and Military Efforts in Stabilization Operations", Rusi, 153:6 (2008), 70; Max Stephenson, "Making Humanitarian Relief Networks More Effective: Operational Coordination, Trust and Sense Making", Disasters, 24:5, 29; Olson and Gregorian, "Civil-Military Coordination: Challenges and Opportunities in Afghanistan and Beyond".

64 Olson and Gregorian, "Civil-Military Coordination: Challenges and Opportunities in Afghanistan and Beyond", 11; Nicholas Stockton, Strategic Coordination in Afghanistan (Washington DC: Afghanistan Research and Evaluation Unit, 2002).

65 Stewart, "The US Response to Precarious States: Tentative Progress and Remaining Obstacles to Coherence".

66 Baumann, "Clash of Organizational Cultures? The Challenge of Integrating Civilian and Military Efforts in Stabilization Operations", 70-72.

67 Hans Binnendijk and Stuart E. Johnson (eds), Transforming for Stabilization and Reconstruction Operations (Washington DC: National Defence University Press, 2004); Stephenson, "Making Humanitarian Relief Networks More Effective: Operational Coordination, Trust and Sense Making”, 29. 
support' and 'team structure'. They argued that 'imposing some definitional rigor, methodological clarity, and plausible categorization on the literature' provided 'a solid platform for interagency team research' that produced immediate benefits. Previous success stories were cited to enhance the credibility of their idea. But Orton and Lamb's assertion - that certain principles for cooperation can be universally applied - is questionable. Nation-building in Afghanistan was far more complex than domestic cardio surgical teams, national parks fire-fighting teams or anti-narcotics operations in Columbia. ${ }^{68}$

Mirroring the US government, think-tanks posited that a central processing hub was required. ${ }^{69}$ A National Defence University (NDU) report advocated the creation of a National Interagency Contingency Coordinating Group, which would incorporate representatives from all the relevant agencies, in order to provide 'strategic guidance', 'coordinate planning' and 'review lessons learned'. This included the creation of two joint 'stability and reconstruction divisions' (S\&R divisions), which functioned as 'substantial assets in such categories as military police, construction engineers and civil affairs'. These assets were essentially the same as PRTs, and contained little in the way of intergovernmental collaboration. Moreover, they required, as the NDU report itself admitted, a significant and abrupt shift in military culture. ${ }^{70}$ NDU's publication PRISM was a sounding board for dramatic reorganizational theories. In one volume, for example, Baker acknowledged the lack of an 'institutional home for developing a US strategy for fragile states', which determined that there was 'no shared methodology, conceptual framework or analytical approach that integrates lessons'. She canvassed a 'Directorate for Conflict Prevention and Sustainable Security' as a conceptual foundation to unite the agencies in a way that was 'predictable, repeatable and efficient', in order to facilitate 'operational principles and procedures for a whole-of-society approach'. ${ }^{71}$ Burke, meanwhile, argued that civilians should have 'unequivocal authority' in nation-building. He promoted the virtues of a 'single civil-military agency with a pooled budget to take a clear lead on humanitarian aid and reconstruction in the areas worst affected by insurgency'. ${ }^{72}$ But how the two initiatives could have succeeded, where similar government programmes failed, was not explained by either of the authors.

Jorgensen, on the other hand, advocated a reorganization of the executive branch 'in order to put the "inter" into interagency'. He believed that this could be achieved with a 'statutory, structural, operational and human adjustment' through legislation. This involved birthing Regional Interagency Directorates (RIDs) to 'build a common global operating picture'. Specifically, using a military

68 James Douglas Orton and Christopher Lamb, "Interagency National Security Teams: Can Social Science Contribute?" PRISM, 2:2 (2010).

69 Commission on Wartime Contracting, An Urgent Need: Coordinating Reconstruction and Stabilization in Contingency Operations, 2.

70 Binnendijk and Johnson, Transforming for Stabilization and Reconstruction Operations, 110.

71 Baker, "Forging a US Policy Toward Fragile States", 72-80.

72 Burke, "Leaving the Civilians behind: The Soldier-diplomat in Afghanistan and Iraq", 42. 
command model, a 'vertical reorganization' would facilitate the 'reinvention of the Cabinet' by connecting RIDs to the President. He even invented a 'President's Security Council' and positions such as the 'Senior Secretary of Domestic Policy' and 'a Department of Foreign Policy', as a vanguard for his reforms. ${ }^{73}$ Ironically, his ambitious plan was constructed at precisely the same time that Holbrooke was struggling to make any headway in a similar role that included authority over just one of the two nation-building fronts.

Instead of pursuing a top-down approach, some tackled the issue at the ground level. Etzioni dismissed the viability of cooperation efforts in alien environments, advocating a Spartan response centred on small-scale projects at the local level, such as roads and other practical programmes, which he claimed had a flow on effects. Yet Etzioni failed to account for the inherent fragmentation of the US government. For example, while he argued that security sector reform should be prioritized by all agencies, he failed to account for the fact that this precipitated military domination, which as Part II showed, was resisted by the civilian branches. ${ }^{74}$ Olson and Gregorian suggested that mechanisms should have been applied to prevent NGO agendas from being warped by the military. ${ }^{75}$ This may have been valid in an international context, but when applied to the United States it ignored both the problem of inter-agency machinations and more specifically the gulf between Washington and the field.

Part of the reason for the broad and sweeping assumptions that permeated academia was the lack of quantitative data. Surveys that identified bureaucratic failures and successes were, for the most part, inadequate in size and scope. Those that did draw on more than just a few first-hand accounts were usually restricted to one department. RAND's 2011 study on the army's role in inter-agency operations, for example, surveyed approximately 100 individuals, only 16 of whom were civilian officials. The study asked military men about their developmental experience and skills, but that was hardly a useful gauge for enhancing intragovernmental cooperation. The designers of the survey admitted as much themselves, cautioning against using their findings, and even questioning its ability to predict clear trends and results. ${ }^{76}$

Overall, the recipes for harmonizing agency priorities and actions were not realistic given the structural impediments that any such plans faced. This led Kapstein to argue that rather than hanging to the false hope that objectives can be harmonized, it would be better to simply speak in 'the hard language of priorities, requirements, trade-offs and limitations'. As Cohen summarizes, 'no matter how

73 Eric Jorgensen, "Greater than the Sum of its Parts: Putting Inter into inter-agency", PRISM, 2:2 (2011), 29-41.

74 Amitai Etzioni, “A Self-Restrained Approach to Nation-Building By Foreign Powers", International Affairs, 80:1 (2004).

75 Olson and Gregorian, "Civil-Military Coordination: Challenges and Opportunities in Afghanistan and Beyond", 28.

76 Markel et al., Developing US Army Officers' Capabilities for Joint Interagency, Intergovernmental, and Multinational Environments, 7-8. 
much guidance is given and how many documents are published . . . reforming the interagency process to account for these operations has proven even more challenging'. ${ }^{77}$

\section{The Shortness of Staff Postings}

A final matter that hampered the capacity of mechanisms and individuals to organize nation-building was the shortness staff postings to Afghanistan. The US foreign policy bureaucracy ensures that military and civilian officials move through a conveyer-belt system of appointments. From 2001 to 2012 there were 10 US military commanders and 7 different ambassadors, which compromised the potential for a united leadership. ${ }^{78}$ More generally, civilian deployments usually lasted from three to six months, and although military tours of duty were longer they were nomadic. Neither of these two situations was satisfactory for fostering inter-agency relations that could overcome entrenched behavioural norms.

The fact that the experiences of each official who served in Afghanistan were not captured is a connected problem. One insider claimed that it 'was almost impossible to have a learning organization when you change people all the time'. Short tours were endemic to all Embassy staff, which resulted in an 'institutional frontal lobotomy of lost experience'.$^{79}$ In order to operate effectively in an environment like Afghanistan, another US official contended, time was required to familiarize oneself with the local culture and environment. But once that was achieved civilian officials were already set for rotation. US officials, from Ambassadors to USAID contractors, left assignments before their successor arrived. There was no established transition period, nor was there debriefing upon rotation. As a consequence, gaps were left after each departure and 'people's experience travelled with them'. ${ }^{80}$ When Ambassador Finn left his posting in July 2003, for example, the deputy chief of mission became acting Ambassador for four months. Meanwhile, Finn's successor, Zalmay Khalilzad, moved sporadically between Kabul and Washington. After Khalilzad left, the disconnect between him and his successors was responsible for a number of high-profile projects, such as an agricultural school, languishing or being cancelled.

'There wasn't a learning curve', a Senior Defence Department Official explained. Three problems resulted. In the field the learning curve had to begin again each time as did personal relationships. By the time an official developed an understanding of how divergent agency interests and culture could be harmonized they were rotated. Moreover, military commanders in Afghanistan had 'an endemic habit that "well I'm doing something different to the previous guy".

77 Ethan B. Kapstein, “Do Three D’s Make An F?: The Limits of Defence, Diplomacy and Development", PRISM, 1:3 (2010), 22; Cohen, "A Tale of Two Manuals", 93.

78 Author Interview with a US Military Commander, Washington DC, April 29, 2012.

79 Author Interview with a Senior State Department Official, Washington DC, April 18, 2012.

80 Author Interview with a Senior USAID Official, Washington DC, April 23, 2012. 
So each time you'd get a shift in emphasis' ${ }^{81}$ Another Senior State Department Official shared the opinion of his colleague from the Department of Defence, but centred his analysis of staff appointments on the President. Bush had the ability to effect staff appointments, but an absence of effort made it difficult for Dobbins to obtain even a skeletal staff cadre. As a consequence of 'the system not being energized from the top', moving 15 staff members from existing jobs was successfully resisted by the hierarchical State Department bureaucracy. He cited this as another example in which White House neglect facilitated bureaucratic torpor. ${ }^{82}$

Measures were undertaken to prevent the loss of experience, but they crashed against the cliffs of the bureaucracy in Washington. Reforming the staff rotation system was Sisyphean: 'at the fundamental level you're trying to get a piece of the bureaucracy to move in a direction that is antithetical to the way the rest of the bureaucracy is moving' ${ }^{83}$ When Dobbins attempted the smaller task of increasing the number of staff at the US Embassy, he still 'waged a losing battle against bureaucratic inertia' ${ }^{84}$ Moreover, officials who expressed a willingness to extend a tour in Afghanistan provoked resistance from agencies that proved unwilling to accommodate such a move, which supposedly would circumvent its cultural traditions and standard procedures. For that reason, USDA officials were unable to prolong their commitment beyond a year.

The fleeting nature of such deployments also heightened tension between the civilian and military realms. Civilian officials typically undertook four separate tours, often moving between Afghanistan and Iraq within the space of a year. This resulted in a dichotomous influx and exodus that frustrated military commanders: 'Washington sent State and USAID officers where they were most needed and left other positions empty', but those empty positions 'helped fuel the military's perception that the civilian branches were emaciated and disorganized'. ${ }^{85}$ Alternatively, one USAID staffer remained in Helmand province for 3.5 years, making him the longest-serving civilian official in Afghanistan. He was respected by military and civilian officials alike for his rapport with the locals and his ability to understand the best way forward for US reconstruction projects. But this was an exception rather than the norm. In 2009, 40 per cent of civilian officials in Helmand stayed for less than 6 months. ${ }^{86}$

Within the military establishment, meanwhile, US soldiers were rotated at the very moment that they came to understand the intricacies of local politics and culture. New troops, who were prepared for war-fighting and little else, would then 'come in and start making the same dumb mistakes and doing the same

81 Author Interview with a Senior Defence Department Official, via telephone, Sydney to Colorado, July 15, 2013.

82 Author Interview with a Senior State Department Official, Washington DC, April 15, 2012.

83 Author Interview with a Senior State Department Official, Washington DC, April 18, 2012.

84 Dobbins, After the Taliban: Nation-Building in Afghanistan.

85 Author Interview with a Senior State Department Official, Washington DC, April 18, 2012.

86 Rohde, "Little America: An Afghan Town, an American Dream and the Folly of For-Profit War"; Hersh, "Afghanistan: The Long and Winding Roads". 
dumb things'. Nor was the problem limited to the experiences of regular soldiers. Regional headquarters moved on a full block rotation model so when the flag left so did all senior staff, who were replaced by a different unit with completely new officers: 'It was the first day of school for everyone all the time'. Moreover, the rotation of troops on such a swift basis was a catalyst for domestic Afghan opportunists to behave capriciously without repercussion. Each month, 'a lot of players started to change their bets on the table' ${ }^{87}$ As staff rotated and collaboration between US agencies dissipated, strongmen and tribal leaders exploited the ensuing disorganization, at the expense of the Afghan State and its people. Civilian projects that did continue were hampered by the constant rotation of military units, which forced State Department and USAID officials to explain the merits of their projects anew every few months.

\section{Conclusion}

Discordant approaches to nation-building in Afghanistan resulted in the proliferation of many mechanisms that were devised to facilitate cooperation. Agencies such as the State Department, USAID and the military establishment were, at various times, empowered to steer governmental cooperation. Another strategy centred on the creation of new authority figures to bridge divisions, while a less formal avenue involved personal relations between the US Ambassador to Afghanistan and the Commander of the Combined Forces. None of these efforts was effective in overcoming dysfunctions within the US foreign policy bureaucracy.

$\mathrm{S} / \mathrm{CRS}$, in theory, seemed an appropriate solution to the intra-governmental problems created by the ambiguities of nation-building, but it underestimated the tenacity of different agency interests, culture, perceptions and power. S/CRS and the other mechanisms devised by the US government were fragmented and over-lapping. Many were warped to suit a specific agency's interests, while others reflected a certain agency's culture. Proposals from academics and think-tanks were, for the most part, similarly delusional because they ignored the behavioural nuances of agencies, factions and individuals, and the realities of structured divisions between agencies.

Meanwhile, individuals such as Holbrooke and Eikenberry maintained particular perceptions of how to approach nation-building in Afghanistan. Holbrooke, who was tasked with the overarching responsibility of organizing the nationbuilding mission, was derided as an official who embodied State Department interests and exemplified its culture. At the same time he faced opposition within the State Department for attempting to construct a power-base that threatened established procedures and factions. Despite his credentials, experience and expertise, therefore, Holbrooke failed to surmount the bureaucratic obstacles that prevented a whole-of-government approach. Eikenberry, meanwhile, could not form a perception that sat outside the narrow agenda of the military establishment, 
even when he was US Ambassador to Afghanistan. Alternatively, the amiable relationship between Barno and Khalilzad offers a sliver of hope that commitment and empathy between two powerful figures can overcome bureaucratic problems. But although the two men worked together in Kabul, factions from State and the military in Washington remained at loggerheads. Even though personal relations could overcome formalized procedures and entrenched behavioural norms, moreover, the issue of staff terms proves that any progress made is lost once US officials and soldiers rotate. With this in mind, we will now turn to what has been perceived to be the most successful vessel for a whole-of-government approach to nation-building in Afghanistan: Provincial Reconstruction Teams. 


\title{
9 Provincial Reconstruction Teams
}

\author{
A Microcosm of US \\ Nation-Building in Afghanistan*
}

Following the fall of the Taliban regime, the US created Coalition Humanitarian Liaison Cells (CHLC), consisting of five to twelve soldiers who engaged in small-scale state-building activity. Some early success encouraged the expansion of CHLCs into PRTs, which represented a nimbler alternative to an International Security Assistance Force (ISAF) presence outside Kabul. PRTs implemented quick-impact projects to win the 'hearts and minds' of the Afghan populace, years before the trumpeted shift to such a strategy occurred. ${ }^{1}$ By the end of the Bush Administration's second term, 12 US-led PRTs, mandated to promote security, reconstruction and good governance, were in operation. PRTs implemented quick-impact projects, comprising business, agriculture, public health and infrastructure. PRT commanders were responsible for security and inter-agency coordination, and received policy guidance from an Executive Steering Committee based in Kabul. The State Department, USAID and the Department of Agriculture (USDA) had leading civilian roles. ${ }^{2}$ In contrast to initiatives centred in Washington and ideas that were presented outside of the government, PRTs nominally involved practical cooperation between agencies in the field.

PRTs married the military and security aspects with the civilian and development aspects. ${ }^{3}$ Condoleezza Rice called them 'a model of civil-military relations for the future'. ${ }^{4}$ The Department of Defence (DoD) stated that PRT's

* Some sections of Chapter 9 appeared in "Bureaucratic Politics, Role Conflict and the Internal Dynamics of US Provincial Reconstruction Teams", Armed Forces and Society 42:1 (2016), 99-118. Reprinted by permission of Sage publications - www.sagepublications.com.

1 Andrew Enterline, Emily Stull and Joseph Magagnoli, "Reversal of Fortune? Strategy Change and Counterinsurgency Success by Foreign Powers in the Twentieth Century", International Studies Perspectives, 14:1 (2013), 176-198; Greg Mills and Ewen Mclay, "A Path to Peace in Afghanistan: Revitalizing Linkage in Development, Diplomacy and Security”, Orbis 55:4 (2011), 600-612.

2 Government Accountability Office, Provincial Reconstruction Teams in Afghanistan and Iraq, Washington, October 1, 2008.

3 Author Interview with a Senior State Department Official, Washington, April 21, 2012.

4 Condoleezza Rice, "Rethinking the National Interest: American Realism for a New World", Foreign Affairs, 87:4 (2008), 2-27. 
combined key features of US national power in support of nation-building, while a USAID report declared the programme 'an effective tool for stabilization in Afghanistan'. ${ }^{5}$ In a word, PRTs were presented as a panacea for the inter-agency conflicts and infighting that had bedevilled nation-building in Afghanistan.

This chapter delves beneath this rhetoric to argue that PRTs, like all of the other proposed solutions to bureaucratic incoherence, were compromised by agency interests, culture, perceptions and power. In fact, they were nothing less than a microcosm of the US nation-building effort in Afghanistan. I proceed with a comparison of some laudatory and critical accounts of the programme and then continue with a comparative evaluation of military and civilian agency roles. Finally, I make some brief remarks about the relationship between the counterbureaucracy and PRTs.

\section{Praise and Critique}

In some policymaking circles, PRTs were acclaimed as a 'missing link' that successfully integrated the US agencies involved in Afghanistan. Several of these accounts depicted PRTs as a pioneering approach to intragovernmental cooperation. Cobane argued that PRTs represented 'a unique and successful solution' to Afghanistan's many problems. For McNerney, they fulfilled a number of important tasks such as school building, election support, security, reconstruction, community empowerment, disarmament and mediation. In government circles it was accepted that reconstruction projects benefited from the support of PRT units due to their capacity to conduct needs assessment, mobilization of local partners, and a comprehensive knowledge of localities in which they were stationed. A senior USAID official described PRTs as 'an innovative response to an extremely challenging environment'. ${ }^{6}$

Others who witnessed them in action were also impressed. Dobbins described PRTs as 'substantial organizations' that successfully implemented development in rural areas. PRTs 'had a significant effect', symbolic and practical, by providing resources where there were major security challenges. At ground level, a lieutenant experienced 'a quality programme'. Another viewed PRTs as the 'cutting edge of military transformation'. ' The nation-building credentials of specific PRTs

5 USAID, Provincial Reconstruction Teams in Afghanistan: An Interagency Assessment, Washington DC, June 2006; Department of Defence, Report on Progress Toward Security and Stability in Afghanistan, Washington DC June 2009.

6 Craig Cobane, "Provincial Reconstruction Teams and Security Assistance: Comments on an Evolving Concept", Journal of International Security Assistance Management, 27:4, 2005, 91-98; Michael McNerney, "Stabilization and Reconstruction in Afghanistan: Are PRTs a Model or a Muddle?" Parameters, 35:4 (2006), 32-46; Author Interview with a Senior USAID Official, Washington DC, April 19, 2012; Author Interview with a Senior USAID Official Washington DC, April 23, 2012.

7 Dobbins, After the Taliban: Nation-Building in Afghanistan; Independent Task Force co-sponsored by the Council on Foreign Relations and the Asia Society, "Are We Losing the Peace?" (New York: Council 
were applauded in Washington. PRT Gardez was praised on multiple occasions for implementing successful economic and social projects, enabled by collaboration between military and civilian members. Others were extolled for the reconstruction of schools and a university. ${ }^{8}$

Yet overall, the evidence relied upon to talk up PRTs was tenuous and selective. Assumptions about performance were sometimes based on the amount of money that had been spent. Complimentary descriptions were frequently broad and sweeping and ignored failings. While the concept of PRTs was lauded by the White House, USAID, the State Department and the Pentagon, their performance in practice was beset with problems. According to Schirch, PRTs actually 'inhibited development of military relationships with civil society'. Joel Hafvenstein, a USAID contractor, dismissed the idea that PRTs created a nucleus of security and development. The most useful thing that Hafvenstein witnessed was the PRTs' provision of ice for his company's drinks. Stapleton argued that PRTs functioned more as a political tool than an effective bridge between security and development. Luehrs found there was a failure to communicate and share information, exacerbated by the geographic distance between Washington and Afghanistan. ${ }^{9}$

US Government sources identified similar problems. GAO reports recounted a fragmented approach where policy was divided up between agencies. According to the US House of Representatives Committee on Armed Services, there was 'no clear definition of the PRT mission, no concept of operations or doctrine, no standard operating procedures'. The committee uncovered 'complicated, disjointed and, at times, unclear chain(s) of command' that received direction from multiple sources, which in turn resulted in a 'confusing array of pots of money with differing authorities and limitations', ${ }^{10}$

\section{The US Military}

For the PRTs, the presence of diverse - and divergent - interests, perceptions, culture and power hindered cooperation and exacerbated bureaucratic problems. There were various influences on the goals and methods of these small joint-civil military teams, but because they were predominantly staffed by soldiers, PRTs

on Foreign Relations, 2003), 11; Vince Crawley, "Rumsfeld Wants Soldiers Off Afghanistan Rebuilding Teams", Army Times, March 15, 2004.

8 Rashid, Descent into Chaos, 199; Zakheim, A Vulcan's Tale, 265.

9 Lisa Schirch, Civil Society-Military Relations in Afghanistan (Washington DC: United States Institute of Peace, 2010), 56; Hafvenstein, Opium Season: A Year on the Afghan Frontier, 96-122; Barbara Stapleton, "A Means to an End? Why PRTs are Peripheral to the Bigger Political Challenges in Afghanistan”, Journal of Military and Strategic Studies, 10:1 (2007), 1-49; Christoff Luehrs, "Provincial Reconstruction Teams: A Literature Review", PRISM, 1:1 (2009), 100.

10 Government Accountability Office, Provincial Reconstruction Teams in Afghanistan and Iraq; United States House of Representatives, Agency Stovepipes vs. Strategic Agility: Lessons We Need to Learn from Provincial Reconstruction Teams in Iraq and Afghanistan, 18-35. 
remained rigid units that adhered to the operational paradigm and lexicon of the military. Some considered that to be beneficial. In a conflict-ridden environment the ability to call upon combat units for 'over-the-horizon firepower through the use of close air support and quick reaction forces', was 'used to good effect'. ${ }^{11}$ However, on balance the pervasiveness of military culture and interests that were centred on counter-insurgency had a detrimental impact on intragovernmental collaboration and the implementation of projects.

The first problem was the military's emphasis on security. Security was a key pillar of PRT operations, but the priority given by the military to protecting themselves and their PRT contingent far exceeded that accorded to any interests of the Afghan populace or to development projects. Hafvenstein recalled that soldiers from the PRT in Helmand 'spent their time behind their formidable walls and barbed wire moat on the outskirts of Lashkaragah'. Even on the rare occasions they did leave their base 'it was in full body armour, riding Humvees with gun turrets'.$^{12}$ In another example involving a meeting with local Afghan authority figures, the State Department's PRT representative was accompanied by a group of 16 soldiers in heavily armoured vehicles. Such a hostile party hardly conveyed the impression necessary to win the trust of sceptical tribal authorities with a history of animosity toward foreigners. In battleground regions, Special Forces operated out of PRT compounds, which they used as holding grounds for suspected terrorists or places to interrogate prisoners of war.

Military mentality also adversely affected reconstruction. Due to the resources at its disposal, the military was in charge of planning and executing PRT projects. But its command apparatus was not ideal for that purpose. PRTs reported directly to military task forces, which would then report to regional and central commands. They received instructions from brigade headquarters and the PRT commander dispersed funds. These were readily available through the Commanders' Emergency Response Program (CERP), which, as we discovered in Chapter 5, enabled them to allocate funds 'for the rapid implementation of small-scale projects, such as providing latrines for a school or a generator for a hospital'. CERP funds, however, were used without consulting the State Department, USAID or USDA, each of which had more experience and expertise in nation-building than their military counterparts. ${ }^{13}$ A senior military officer contrasted the military's objectives with those of USAID:

In almost every PRT, there is this friction that develops between folks from USAID who want to go into the big projects, fix things for the long term,

11 Michael Dziedzic and Michael Seidl, Provincial Reconstruction Teams and Military Relations with International and Non-governmental Organizations in Afghanistan (Washington DC: United States Institute of Peace, 2005), 4.

12 Hafvenstein, Opium Season, 207; Stapleton, “A Means to an End?”, 43.

13 Government Accountability Office, Afghanistan Reconstruction: Despite some Progress, Deteriorating Security and Other Obstacles Continue to Threaten Achievement of US Goals, Washington D.C., July 2005, 18; Rubin, Afghanistan's Uncertain Transition From Turmoil to Normalcy, 6. 
while the unit commanders are looking for things that can create conditions that provide immediate results. ${ }^{14}$

While the main currents of agency culture permeated military operations, there was some latitude for individual initiative. But the style and mentality of commanders reflected military interests. Colonel Augustine, commander of the Helmand PRT, for example, cajoled USAID contractors into operating in dangerous areas. He had no patience with the argument that this was unfeasible in the absence of cooperative local powerbrokers or a reliable police force. Fast spending and high visibility were prioritized to meet counter-insurgency objectives. The military favoured endeavours that displayed tangible if transient indications of progress, even where these were unsustainable and not supported by the population. ${ }^{15}$

As with USAID's approach to reconstruction projects, PRT commanders would outsource to contractors. A reluctance to leave the comfort zone of their bases to monitor activities contributed to funds being lost to fraud, neglect and human error. Schools were built without teachers, clinics without medics, and infrastructure projects had insufficient materiel or manpower. A soldier from Gardez described as 'uniformly poor' the results of a project in the Paktika provinces, where 'you could put your feet through the sidewalk' ${ }^{16}$ At most, PRTs conducted sporadic visits to monitor project sites, but these were to collect photos and statistics, which were then presented to the Pentagon as evidence that they had delivered results. When a new PRT commander was appointed, he was usually unaware of what had been implemented by his predecessor. Consequently, each tried to reinvent the wheel at the beginning of their tour.

Some still lauded PRTs as a model for inter-agency collaboration involving equal levels of input. But as with the broader nation-building mission, PRTs displayed a power discrepancy, with the civilians having no independent funds until 2004. Even after that, the military retained control over most resources and manpower. The composition of PRTs confirms that they were essentially a creature of the military rather than an authentic fusion of governmental agencies. On average, only two civilian representatives were ensconced in a PRT at any time. Even the largest contained a mere three or four. By 2009, there were 1,021 military personnel in PRTs compared with 34 from the DoS, USAID and USDA combined. This equated to one civilian for every 30 military personnel. A Senior State Department Official lamented the asymmetry, noting 'we had one AID officer in each PRT with very little project money and with no local staff' ${ }^{17}$

Many problems were directly linked to the differences in capacity between the military and civilian spheres. In most PRTs, the military eschewed guidance

14 Yodsampa, No One in Charge, 144.

15 Hafvenstein, Opium Season, 207.

16 Stapleton, “A Means to an End?”, 24; Hafvenstein, Opium Season, 312.

17 GAO, Provincial Reconstruction Teams in Afghanistan and Iraq, 2; Author Interview with Ronald Neumann, Washington, April 18, 2012. 
from civilian representatives. An inter-agency assessment by USAID found that PRT commanders failed to incorporate non-military components into leadership decisions. A common complaint voiced by former civilian personnel was that they were treated like outsiders. In Gardez, the State Department representative requested that the PRT undertake police training assistance, but the military commander dismissed his concerns. One former PRT member noted that 'this also really confused Afghans and aid agencies who didn't understand why the military part of a PRT was building schools and clinics when the local police have no uniforms, vehicles or facilities'. Another opined that there had been 'no real understanding of how civilians could contribute to the team'. A State Department official summarized the gulf of understanding caused by different cultural norms: 'there are a lot of acronyms that fly around and a lot of things that are just common language for everybody involved with the military and really alien for people who aren't'. ${ }^{18}$

Frictions between civilian and military elements were exacerbated by the PRTs being answerable to numerous chains of command. A survey conducted on the experiences of USDA officials found that this prevented some from fulfilling their role as agricultural advisors. Relationships with task forces, brigades, and regional commanders were often disorganized or conflicting. Yet despite their subordination to military culture - virtually functioning as combat units under a different name - some military officials perceived the PRTs to be interlopers, even dismissing them as civilian entities. Task Force Saber, for example, pursued its own political mandate and refused to cooperate with the local PRT. Saber's commander actively supported Ismael Khan, a local warlord widely considered to be brutal and corrupt. When PRT representatives informed the commander of this he blatantly ignored their counsel. Other reconstruction projects spearheaded by the military were undertaken without input from the local PRT. ${ }^{19}$

There was also a lack of coordination between the US Army National Guard's Agribusiness Development Team (ADT) activities and PRT agriculture projects. ADTs operated separately from the PRT command structure and were considered by the military to be more experienced than USDA. Therefore, they tended to implement projects without drawing on USDA officers for assistance or advice. From the perspective of USDA this was a sub-optimal way to approach agricultural reform in Afghanistan. Officials at the Pentagon, however, disagreed. They considered the USDA representatives to be 'bureaucrats from the foreign

18 Author Interview with a US Military Commander, Washington DC, April 29, 2012; USAID, Provincial Reconstruction Teams in Afghanistan: An Interagency Assessment; McNerney, "Stabilization and Reconstruction", 36-40; Agency Stovepipes vs Agility, 22-73; Carlos Hernandorena, "US Provincial Reconstruction Teams in Afghanistan, 2003-2006: Obstacles to Interagency Cooperation", in Joseph Cerami and Jay Boggs (eds), The Interagency Counterinsurgency Warfare: Stability, Security, Transition, and Reconstruction Roles (Washington DC: Strategic Studies Institute, 2007), 121-171.

19 Bernard Carreua, "Lessons From USDA in Iraq and Afghanistan”, PRISM 1:3 (2010), 139-150; Robert Perito, "The US Experience with Provincial Reconstruction Teams in Afghanistan", United States Institute of Peace Special Report, No. 152, October, 2005, 8. 
agricultural service who knew how to move papers but that didn't know how to plant anything', ${ }^{20}$

Meanwhile, in Washington it was the regional bureau within the Office of the Under Secretary of Defence for Policy (USDP) that provided guidance for the military wing of the PRTs, rather than the Deputy Assistant Secretary of Defence for Stability Operations Capabilities, a position created expressly with nationbuilding in mind. DoD organs did not want the new Secretary to encroach on their traditional sphere of responsibility. But the bureau had little comprehension of how the PRTs should approach reconstruction. PRT Helmand greeted Afghan elders with PowerPoint presentations that advocated freedom of speech and demonstrated plans for luxurious hotels and the establishment of a free press. These ideas were the brainchild of Pentagon bureaucrats who had no accurate conception of the wants and needs of a populace whose country had been devastated by more than three decades of war. They were alien to the tribal leaders. PRT commanders found it hard to articulate and justify their own policies, but adherence to the priority to obey orders determined that they did little to redress the problem.

\section{Civilian Agencies}

Military interests, perceptions and culture had a pervasive influence on PRTs. But that did not entirely explain why civilian representatives were less effective than they could have been. The clash of agency cultures was one of a combination of factors including incompatible interests, personnel issues, bureaucratic delays and inadequate training. These issues not only widened the cleavage between civilian and military branches, but also exposed conflict and discord within the civilian realm.

The lack of coordination between the State Department, USAID and USDA manifested very different priorities. Civilian members were beholden to the DoD regional bureau or the Director of Foreign Assistance, who, confusingly, was also the Administrator of USAID in Kabul. Moreover, this 'system' undermined the State Coordinator for Reconstruction and Stability (S/CRS), an office that was created to mediate relations between departments. Instead, each agency pursued its own myopic strategy and officials reported separately to their superiors at the US embassy. In Washington, competing visions of how best to organize the PRTs emerged from the DoS, USAID and USDA. As a result, the civilian element of Afghanistan's PRTs comprised an incoherent assortment of diplomats, political advisors, development advocates and agricultural experts. Deployment was approached arbitrarily and reflected agency interests rather than the specific needs of the individual PRTs, which operated in regions that presented their own unique challenges. But 'because it was voluntary, you didn't get the people you needed'. ${ }^{21}$

20 Carreua, "Lessons From USDA in Iraq and Afghanistan", 145; Author Interview with a Senior Defence Department Official, via telephone, Sydney to Colorado, July 15, 2013.

21 Author interview with a Senior State Department Official, Washington, April 30, 2012; Author Interview with a Senior Defence Department Official, via telephone, Sydney to Colorado, July 15, 2013. 
In some instances, civilian PRT members had no knowledge of the expertise possessed by those outside their agency. An official stationed at the Parwan PRT said he had been given no operational instructions: 'Nobody really gave me any guidance', he remembered. 'I was just basically cut loose and told, "Okay, you're at the PRT" and that was about it. Nobody told me anything. I had no idea of my function, or what my role was going to be'. Another despaired that his PRT was akin to a 'Sunday pick up team' rather than 'a cohesive unit'. ${ }^{22}$

Coordination problems were entwined with personnel issues. From the beginning of 2007 until mid-2008, the number of civilian officials serving in PRTs increased by just four and at the end of 2008 USAID had fewer personnel in Afghanistan PRTs than was authorized. Although there were nominally at least two USAID officials in each PRT, due to the haphazard nature of the agency's rotation system there was sometimes only one or none. Meagre civilian manpower circumscribed the PRTs' capacity to undertake projects because they 'were limited by the availability of US government civilians'. The US military attributed this to issues within the State Department, USAID and USDA where there was 'a tremendous tug of war to get those civilians out there and then keep the pipeline filled with those people and not have gas as time went on'. Similarly, State Department sources confirmed that it was a significant effort to provide even a small civilian presence for each PRT. ${ }^{23}$ Moreover, there were gaps between deployments. When civilians left it would often be months before they were replaced and each time a new person joined, the relationship-building process had to start again. One former commander remembered that 'there was no consultation about which State officers would be posted at what PRTs, and on what schedule', resulting in 'gaps at critical times'. A member of the Herat PRT recalled that,

Every PRT is supposed to have one civilian each from the Department of State, USAID, and the Department of Agriculture . . . My PRT didn't have any of those people, so USAID, in the absence of any of their employees, would delegate their duties to State, so the whole time I was there I was also wearing a USAID hat. ${ }^{24}$

Regular tours of duty lasted for a maximum of 6 months, and it was extremely difficult to find civilians who were willing to spend more than the minimum 3 months stationed with a PRT. A State Department representative who served two 90-day tours in Tarin Kowt and Jalalabad said that he 'basically went to places

22 Carreua, "Lessons From USDA in Iraq and Afghanistan", 145; Perito, The US Experience with Provincial Reconstruction Teams in Afghanistan, p. 11, Agency Stovepipes vs Agility, 73.

23 Special Inspector General for Afghanistan Reconstruction, Provincial Reconstruction Teams in Afghanistan and Iraq, Quarterly Report, p. 11, Author, January 2009, 10; Author Interview with a US Military Commander, Washington DC, April 29, 2012; Author Interview with a Senior State Department Official, Washington DC April 21, 2012.

24 Hernandorena, "US Provincial Reconstruction Teams", 140; Perito, The US Experience with Provincial Reconstruction Teams in Afghanistan, 14. 
that nobody else wanted to go'. ${ }^{25}$ Staff shortages were a major problem. Not only did that difficulty exacerbate tensions between soldiers and civilian officials, it sowed discord between civilian branches of government. Other bureaucratic and funding issues were also divisive. USAID had access to the Quick Impact Program (QIP) funding mechanism. Nominally, its personnel reported to USAID headquarters in Kabul on the viability of local infrastructure projects and collaborated with NGOs, Army Civil Affairs teams and their fellow civilian representatives. In comparison to the CERP, QIP funds were difficult to obtain, partly due to poor communication and disorganization within USAID's skeletal staff structure.

The situation in Washington further complicated matters. While it was relatively easy for the military to obtain funds from Congress, for civilian officials it was difficult. Because the US was engaged in a counter-insurgency effort rhetorically and practically - Congress determined that the military's needs were more urgent and important. That could be interpreted as the victory of one party in an otherwise mundane bureaucratic power struggle over resources. But the gravity of the situation where those resources were to be ultimately deployed affects the perspective. According to Michelle Parker, a former PRT representative, PRT commanders used 'CERP funds to initiate projects, because they could obligate those funds quickly, while USAID would go through normal budget processes'. USAID's people lamented delays and that they had little power when it came to decision-making. Everything had to be first run by the mission headquarters in Kabul and then Washington. One official posted in a PRT said that during his deployment 'not one red cent' of QIP money was actually spent. Reforms were slow and it was not until 2009 that USAID officers in PRTs received authorization to spend up to $\$ 25,000$, without approval from both Kabul and Washington. ${ }^{26}$

At least USAID had access to separate funding mechanisms; USDA did not. USAID exploited this advantage to overrule USDA when it came to project direction and implementation. Access to funding strengthened USAID's own 'we know best when it comes to development' mindset. Rather than include other civilian officials, USAID jealously guarded funds it had obtained and took the credit in Washington for completed projects. This behaviour was affirmed when PRTs came under scrutiny from congressional committees toward the end of the Bush administration's second term. An additional consequence of USAID's 'power of the purse' was that commanders paid greater attention to the opinions of USAID officials than those of the DoS and USDA. One USDA representative recalled that his military superior 'listened to USAID officers because they had funding, but he barely tolerated USDA advisors'. ${ }^{27}$

25 Robert Perito, Oral Histories Project on Stability Operations: Provincial Reconstruction Teams (Washington DC: United States Institute of Peace, 2006).

26 Markel et al., Developing US Army Officers' Capabilities for Joint, Interagency, Intergovernmental and Multinational Environments (Washington DC: RAND, 2011), 36; GAO, Provincial Reconstruction Teams in Afghanistan and Iraq, 11; USAID, Provincial Reconstruction Teams in Afghanistan: An Interagency Assessment, 5-16.

27 Carreua, "Lessons From USDA in Iraq and Afghanistan", 144. 
While experience cannot be bought, a major factor hampering cooperation was the absence of a comprehensive training programme to prepare officials for deployment. This was a massive omission as civilians had little understanding of the military's culture, including functions, procedures and nomenclature. The State Department, USAID and USDA were intent on having their officials parrot departmental policy and procedures. The three agencies' inadequate training programmes made little attempt to promote solidarity, instead simply reinforcing predominant agency interests and cultural norms. Consequently, agency representatives were often suspicious of anyone from 'outside'. Nonetheless, junior officials who had no experience in dealing with differing agency cultures were thrust into the field, where they encountered commanders reluctant to take advice from these fledglings. Already wary of the civilian branches of government, commanders perceived these officials to be more of a hindrance than a help, and hence excluded them from decision-making processes. ${ }^{28}$

\section{The Counter-Bureaucracy, USDA and PRTs}

Two further issues warrant some brief remarks. First is the impact on PRT operations of GAO, OMB and congressional committees, all of which had oversight mandates. What PRTs needed was performance-monitoring systems that measured effectiveness along with better management and clearly defined objectives. But Congress displayed a vague understanding of the details and seemed to think solutions to embedded problems would come fast and easy. The oversight agencies fed off congressional interest. The GAO, OMB and SIGAR advocated more scrutiny in respect to funding used by PRTs, and detailed cost and data analysis. PRT members, who were frustrated at the amount of paperwork, resented that. Many questioned whether the metrics used were an appropriate determinant of performance. ${ }^{29}$ The implication was that Congress and Washington's regulatory bodies caused further discord in an already fractious mission.

The second issue is USDA, the forgotten actor in the PRTs. Available data on the department's involvement is scarce and it was neglected in intergovernmental and GAO reports, which focused on the State Department, USAID and the military. There is also little coverage of USDA in think-tank reports or academic studies. Carreua's is the only article that focused exclusively on it. He revealed that USDA members believed they should define the agricultural strategy within the PRTs, regardless of their lack of numbers. USDA's approach was a reflection of their departmental culture, which prioritized certain farming projects and methods and mirrored, in regard to agriculture rather than development, USAID's 'we know best' attitude. Unfortunately for USDA, in the hierarchical structure of the PRTs the US military was on top, followed by USAID and the DoS, and USDA

28 Hernandorena, "US Provincial Reconstruction Teams", 144; McNerney, "Stabilization and Reconstruction", 39.

29 Government Accountability Office, Securing, Stabilizing and Reconstructing Afghanistan: Key Issues for Congressional Oversight, Washington DC, May 2007, 22; Agency Stovepipes vs. Strategic Agility, 73. 
was relegated to the bottom. USDA advisors were perceived to be a burden and a nuisance and the small-scale projects they advocated clashed with both USAID's and the military's philosophies on agricultural development. ${ }^{30}$

Most accounts exploring the impact of PRTs in Afghanistan acknowledge that the programme required improvement. A clear and coherent strategy, better targeted and deployed funding, and a substantial increase in civilian involvement and authority were considered necessary reforms. The most reasonable suggestion was that comprehensive inter-agency training was needed to overcome a lack of cohesion. There has been debate on how a training regime could be successfully directed. Hernandorena suggested that leadership opportunities for civilians could act as a balancing factor and that specific guidelines combined with joint predeployment training would be beneficial. Yodsampa was more specific, outlining an inclusionary mechanism for co-location and methods to instil joint decisionmaking. Carreua proposed that relationship-building between the civilian and military realms was the key to a more effective PRT programme, while Luehrs argued that the purpose of training must be to establish an effective chain of command, a view that was also expressed in US governmental reports. ${ }^{31}$

None of these proposals included a guide on how all reforms could be effectively implemented to overcome entrenched behavioural norms. Past analysis on PRTs often correctly identified a problem, but each solution would fail to bridge the substantial barriers of interests, perceptions, culture and power that the programme in Afghanistan crashed against. PRT members supported this appraisal, with many believing their tours were not valued by their departments, and that they had a negative impact on career progression.

\section{Conclusion}

US PRTs in Afghanistan underperformed as the nation-building outfits that some envisaged. Their generally positive reception in political terms was offset by practical problems, primarily due to conflicting agency interests, an imbalance of power and the differential perceptions of the soldiers and civilians that made up the PRTs, which aligned with their agencies' behavioural norms rather than with an innovative, collaborative approach to nation-building. While there should be no excessive expectations about what PRTs could have achieved, serious shortcomings can be traced back to not getting things right at the start. No sui generis 'PRT culture' evolved, or was allowed to evolve. Instead, rival agency cultures prevailed. For these reasons, PRTs were microcosms of the US experience in Afghanistan, which was characterized by military dominance, insufficient civilian involvement, and blurred lines of responsibility.

30 Carreua, "Lessons From USDA in Iraq and Afghanistan".

31 Hernandorena, "US Provincial Reconstruction Teams", 144-147; Yodsampa, No One in Charge, 172-80; Carreua, "Lessons From USDA in Iraq and Afghanistan", 142; Luehrs, "Provincial Reconstruction Teams", 95-97. 


\section{Conclusion}

In mid-December 2001, US servicemen raised the Stars and Stripes over their new embassy in Kabul. James Dobbins, the US Special Envoy, remarked at the time that this 'symbolizes the return, after more than a decade of absence, of the US to Afghanistan ... we are here, and we are here to stay'. ${ }^{1}$ The euphoria generated by a successful invasion was short-lived. Liberal democracy, at least in the US sense, was always a fantasy, as it ignored Afghanistan's cultural, religious and political traditions, each of which has a rich, albeit troubled, history. Yet there were some achievements. The Taliban had prevented girls from obtaining an education. After a decade of nation-building, 2.5 million were now enrolled in schools across the country. More broadly, the number of children who received some sort of tutelage dramatically increased, from 900,000 to seven million. Death rates among adult males halved and access to clean water has helped to curb disease and improve life expectancy. ${ }^{2}$

Still, given the considerable expenditure of the United States and the international community, which by 2012 had reached $\$ 100$ billion, nation-building in Afghanistan has unequivocally failed. The drug trade accounts for over half of the country's GDP. While poppies abound, hunger is a constant concern and more than half of children under five are malnourished. Corruption continues to define politics at the national, provincial and local level. Afghanistan sits at the bottom of Transparency International's Corruption Perception Index and the Human Development Index ranks it at 175 of 187 countries. $^{3}$

Afghanistan's Security Forces number close to 300,000, but still suffer from illiteracy, drug addiction and frequent desertion. Many Afghan soldiers and policemen owe their loyalty to tribal authorities, drug barons and the Taliban rather than the Afghan State. The much-trumpeted emancipation of Afghan women belies

1 “Embassies Raise Flags in Kabul”, BBC, December 17, 2001.

2 Kevin Sieff, "In Afghanistan, Underground Girls School Defies Taliban Edicts, Threats", Washington Post, April 25, 2012.

3 Transparency International, Corruption Measurement Tools at http://www.transparency.org/ country\#AFG, and United Nations Development Report, Afghanistan, United Nations, 2013, 2. 
reality; most live in constant fear and 90 per cent are subjected to domestic abuse. ${ }^{4}$ Warlords continue to thrive and power is gained through violence and intimidation. The Taliban, meanwhile, have been reinvigorated. They are received in parts of Afghanistan as the protectors of the populace, while the Afghan government is treated with disdain. With the withdrawal of international forces, Afghanistan is likely to revert back to the lawless, conflict-ridden landscape that existed following the Soviet occupation in the 1980s. US-led nation-building will be remembered as another tombstone in the graveyard of empires.

Domestic conditions, cleavages within the international alliance, and unrealistic ambitions, among an array of other issues, contributed to Afghanistan's current circumstances. But this study has revealed and examined another contributing factor - bureaucratic conflict and incoherence within those US agencies that were charged with nation-building. It is impossible to say just how much this internal division contributed to US failure in Afghanistan - even a completely united state machinery faced huge obstacles - but it was a certainly a significant factor.

\section{Bureaucratic Politics and Nation-Building in Afghanistan}

The impact of bureaucratic politics on US foreign policy has been a neglected area of research. This is particularly evident in the case of nation-building in Afghanistan, with most studies failing to emphasize the contribution of bureaucratic conflict to its failure. By revealing, in detail, the machinations of the US foreign policy establishment, therefore, this study fills a significant gap in the literature.

It began by showing that the US foreign policy bureaucracy - despite sharing a broad ideology that rationalized the rights and prerogatives of the US to intervene abroad in its execution of the GWOT - is made up of a number of agencies, factions and individuals with competing interests, goals and ambitions. To explore these differences and what they meant in practice, I developed a framework centred on differing agency interests, perceptions, culture and power. These four variables, it must be stressed, were mutually constitutive and overlapping. No single one of them stood above the others as a factor that determined behaviour at the inter- or intra-agency level. This framework was not so much a unified theory as a set of conceptual tools for thinking about and examining the inner workings of the US foreign policy bureaucracy. By applying it to the case of nation-building in Afghanistan, I have demonstrated that the US and its foreign policy bureaucracy does not act as a monolithic, rational actor entity, but is instead internally differentiated and often seemingly at war with itself. In particular, the dynamics driving policy implementation can be overwhelmingly internal. With this in mind, the model may be used to extrapolate the US bureaucracies' impact on foreign policy outside of the paradigm of nation-building in Afghanistan.

4 Noorjahan Akbar, "Raped Afghan Women Have No Hope of Justice", Al-Jazeera, July 8, 2011, http://www.aljazeera.com/indepth/opinion/2011/07/2011751254689887.html (accessed 10/1/2014). 
The argument that the United States approached nation-building with a united will and purpose overlooks the fact that bureaucratic forces often defined its approach. Nation-building, a complex and equivocal process, lay outside the orthodox paradigm of any agency's responsibility. The cumulative results of each chapter identified an amalgam of agencies, factions and individuals with a very different understanding of what was required.

If a cohesive approach to nation-building was ever to be realized it would have to have been through the efforts of the President and other top decision-makers. There was little capacity within the relevant agencies to effectively pursue nationbuilding without firm political guidance. Ironically, many of the constraints that US nation-building faced can be levelled at the disinterest of those who were purported to be its architects. The White House, for the most part, allowed the bureaucracy to run its own race. The one partial exception was in respect to governance and democracy. President George W. Bush made it clear to the foreign policy bureaucracy that the ultimate goal of US nation-building was centralized, democratic governance based on elections. Aside from this objective, the White House offered little assistance to harmonize goals and ambitions, besides rhetorical platitudes. Bush himself completely neglected the management of interand intra-agency relations, which enabled the military establishment to dominate proceedings.

The overarching objective of the US military, at least from 2004 onwards, was to roll back the Taliban-led insurgency. It emphasized the extreme nature of the threat and contrived to situate nation-building within the paradigm of counterinsurgency. Yet counter-insurgency was simply another method of warfare, albeit with a new twist, rather than an authentic attempt to reconstruct Afghanistan and assist its peoples. The military willingly subordinated infrastructure development, counter-narcotics and legal reform to the exigencies of its interest in war-fighting. Although combating the insurgency was necessary for effective nation-building, a broader security mandate that stretched beyond simply the war against the Taliban would have better aided the Afghan people and helped promote cooperation with US civilian agencies. Projects such as the Commanders Emergency Response Program (CERP), the Agribusiness Development Teams (ADTs), and the military's Afghan National Police (ANP) and Afghan National Army (ANA) training programmes diverged from the rest of the government. Each of them blended military culture into nation-building activities - usually unsuccessfully. The Pentagon also attempted to use its power and influence in Washington to warp the agenda of the civilian agencies to suit its interests, especially in respect of infrastructure development. Meanwhile, it ignored other initiatives, such as the International Security Assistance Force (ISAF), counternarcotics, and legal reform, because they were perceived to compromise, or neglect, war-fighting objectives.

Attempts to pursue a strategy that did not directly reinforce counter-insurgency were rejected as dangerous developments that were antithetical to military interests. This rationale led the Pentagon to throw its support behind the CIA's warlord strategy, irrespective of the damage it did to Afghanistan's political order. More 
generally, the military's tolerance of Afghan political figures was premised on their assistance with its vendetta against $\mathrm{Al}$ Qaeda and the Taliban-led insurgency. Clearly, the pretence of winning hearts and minds was disingenuous. It came secondary to predominant interests and embedded cultural norms.

The military's attitude is emblematic of a severe imbalance of power between the military and civilian realms, which was a consistent theme that resonated throughout the years of occupation. The economic funds, manpower and other resources at the disposal of the military establishment dwarfed those available to the civilian branches. Civilian agencies, for the most part, were restricted to Kabul, while the military operated throughout the country.

Thus, the two sides of the foreign policy spectrum, military and civilian, were never equal partners. Although military dominance cast a veil of solidarity over the invasion, once nation-building began conflict erupted across a wide range of policies and projects. According to the considerably more powerful military establishment, the civilian branches were inept and disorganized. Comparatively, the civilian branches characterized the military as domineering and ignorant. In general, neither party could see past these perspectives. This diluted the potential of infrastructure development projects, eviscerated the ANP training programme, and compromised feasible nation-building objectives that pooled resources and expertise. Bureaucratic conflict was, however, by no means restricted to the civil/ military dichotomy.

The State Department, to a point, was united in its opposition to the abrasive approach taken by the military establishment. But it was similarly hostile to new authority figures, mechanisms and goals that were perceived to be incompatible with its cultural norms, which have produced complex hierarchies with longstanding traditions of diplomacy and statesmanship. For this reason, organizations, such as S/CRS, and individuals, such as Richard Holbrooke, were treated as intruders. Consequently, they failed to surmount the hurdles that the State Department bureaucracy presented.

Notwithstanding its overarching interest in diplomacy, the State Department is a complex, fragmented and factionalized organization. The US Embassy in Kabul and the Bureaus operated relatively autonomously from their headquarters in Washington. The Bureau of International Narcotics and Law Enforcement (INL), for example, unshackled itself from the rest of the department to undertake a controversial counter-narcotics strategy based on eradication and interdiction. Such disunity obfuscated policy and made it difficult for the State Department to play an effective leadership role. Duplication, redundancy and other management problems combined to disrupt its policies and projects in Afghanistan.

Other civilian agencies, such as the United States Department of Agriculture (USDA) and the Drug Enforcement Administration (DEA), received no coherent guidance from the State Department. As a result, they were free to pursue their own agendas. In the USDA's case, this reflected a particular understanding of agricultural best practice. The DEA, meanwhile, fashioned its approach to counter-narcotics and justice reform in alignment with its previous experiences. By adhering to their cultural traditions, the USDA and the DEA followed narrow 
sectional interests that prevented collaboration. Instead, the two agencies continually clashed with the US Embassy and the INL over policy priorities.

USAID is technically under the purview of the State Department, but more realistically it functions as an independent agency with a unique culture that centres on long-term development. Its capacities have been eroded over the past decades, in terms of staff, resources and the less measurable, but equally important, considerations of influence and prestige. In Afghanistan, there was a disconnect between the agency's paltry staff-base and the vast funds it controlled. USAID's interests in Afghanistan both shaped and reflected its culture. The agency consistently referred to its past experience with long-term, small-scale development in other countries around the world, in order to justify its approach to nation-building in Afghanistan. Despite some plausible ideas, a reliance on outsourcing and poor oversight negated any enthusiasm for its approach in Washington and Kabul.

The self-perception that it had a superior understanding of the right way to approach nation-building was criticized by the military establishment, the State Department and the counter-bureaucracy. These agencies desired immediate results. They coerced USAID to prioritize road-building and agriculture projects in certain regions of Afghanistan that were either the most prominent poppy producers and/ or where the insurgency was strongest. Congress added to the pressure placed upon USAID. It wanted the agency to plant orchards and build schools in Afghanistan's most dangerous and drought-ridden provinces, Helmand and Kandahar. USAID yielded to the pressure of more powerful bureaucratic forces and grudgingly implemented projects that it perceived to be cosmetic. The Kajaki Dam venture, meanwhile, best exemplifies the agency's inability to conduct large-scale nation-building. From the evidence cited in this study, therefore, it is clear that the contemporary USAID is in crisis. Worryingly, its ignominious performance in Afghanistan may well precipitate an even steeper quantitative and qualitative decline.

USAID's reliance on outsourcing was particularly problematic. Contractors such as Berger and Chemtronics were more concerned with profits than best practice, and were entirely different creatures from the smaller, localized contractors that the agency employed elsewhere in the world. In Afghanistan, US contractors sat in a nebulous area between the private and public sphere. It was often unclear as to where the contractor ended and USAID began. The agency lacked the capacity to control or even monitor the projects it outsourced, and the contractors, in turn, failed to manage their sub-contractors. Such blatant mismanagement left a graveyard of unfinished infrastructure projects that stretched across all areas of nation-building.

USAID may have been the main culprit, but a reliance on contracting was not restricted to that agency alone. The State Department outsourced a significant portion of its funds, the most prominent example of which was its employment of Dyncorp. Dyncorp, like Berger, Chemtronics, and other US companies underperformed and the company drastically reduced the capacity of the ANP to function as an effective force. Even the military establishment, with its superior resources, expertise and manpower, employed contractors to implement ADT, CERP and PRT projects. 
Contractors are a legitimate aspect of nation-building, but they played an inordinate part in shaping the US reconstruction programme. This was because each US agency, for different reasons, willingly shifted responsibility to the private sphere. USAID did not have enough officials to pursue its own projects, or the time to find and train suitable domestic companies. Alternatively, the State Department and military encouraged their officials and soldiers to focus on what were perceived to be their more important interests: politics/diplomacy and war-fighting.

The poor performance of contractors contributed to the counter-bureaucracy's involvement in Afghanistan. The counter-bureaucracy is a loose association of regulatory bodies, which are interested in monitoring, regulation oversight and accountability. The military establishment, State Department and USAID were unwelcoming of its encroachment. Mutual opprobrium united them in a way that no formal mechanism for collaboration could. The OMB in particular was perceived to be a significant obstruction due to its power to withhold funds. There is no doubt that its involvement in Afghanistan was harmful, as it circumscribed the development of the ANP and hampered reconstruction projects. But the OMB was not the reason for nation-building failure, despite what officials such as Natsios, Neumann and Zakheim would sometimes imply.

The GAO and SIGAR, meanwhile, were tolerated as a nuisance that could be ignored. Their recommendations were often accepted by the agencies involved in nation-building, more to placate their powerful but unpredictable ally, Congress, than because of a genuine belief that the GAO and SIGAR's suggestions were helpful. Hence, year after year, GAO and SIGAR reports highlighted the same problems and mistakes. The two agencies became increasingly frustrated by the lack of progress they witnessed from the State Department, USAID and the military establishment.

The rational actor model also overlooks the extent to which individuals can influence foreign policy, for better or worse. Senior officials can promote or impede cooperation, when set rules for intragovernmental engagement are not readily apparent. The evidence in this study, however, would suggest that more often than not individuals reinforce cleavages between agencies.

Donald Rumsfeld stands first among the senior US officials who had a detrimental impact on nation-building. His perception of the military's role in Afghanistan left no room for anything besides eliminating the remnants of $\mathrm{Al}$ Qaeda. He ignored or derided the civilian agencies and anyone in the military establishment who thought differently from him. For Rumsfeld, nation-building was merely a nuisance that compromised the Global War on Terror. Channelling this spirit was General Tommy Franks, who observed that he would 'pay any price, bear any burden . . . support any friend, oppose any foe ... [and] shaken hands with the devil if it had furthered our goals in the War on Terrorism'.

Prominent figures such as William Wood and Karl Eikenberry failed to detach themselves from their agency's values. Wood's loyalties lay with the INL. The 
Bureau's culture fed his obsession with counter-narcotics, which provoked conflict within the State Department and between it and the military establishment. Eikenberry, who perceived road-building to be a panacea for insecurity, could not unshackle himself from the interests, perception and culture of the military, even when he was employed as US Ambassador to Afghanistan. Other agency officials may not have actively stifled intragovernmental cooperation, but they still rallied under the banner of their agency when battle lines were drawn.

It is all the more surprising, therefore, that David Barno and Zalmay Khalilzad overcame bureaucratic problems to steer their respective ships toward the same shore. Yet their relationship represented but a temporary and exceptional calm within a storm of disunity. The storm intensified when their predecessors took office, with the one-upmanship that went back and forth between McChrystal and Eikenberry being unsettlingly reminiscent of a soap opera.

Nation-building in Afghanistan also revealed a substantial gap between Washington and the field. A lack of understanding or empathy from factions in the US capital left officials and soldiers - from the US ambassador and the Commander of the Combined forces to regular infantrymen and State Department representatives - demoralized and unappreciated. Those who challenged agency interests and cultures to agitate for a balanced approach to security, infrastructure development and legal reform were usually ignored or resented. The rigid and hierarchical military establishment, especially, ignored the perspectives of soldiers who were interested in more than just counter-insurgency.

Additionally, the shortness of staff terms was unsuited to the long-term nature of the nation-building enterprise. The shortness of deployments prevented a learning curve and institutional memory, which widened bureaucratic rifts between and within agencies. When personnel arrived and departed, progress toward shared goals and common objectives was lost. Meanwhile, dominant agency interests and customary cultural narratives reasserted themselves. The issue was not restricted to any single agency. Steps were not taken to overcome this entrenched phenomenon and it is destined to compromise any foreign policy issue that puts US boots (and suits) on the ground.

\section{Collaborative Mechanisms}

Although no steps were taken to change the lengths of US deployments, a range of collaborative mechanisms were proposed in pursuit of a more effective wholeof-government approach. These had mixed results but on balance proved to be relatively ineffective in combating entrenched agency interests, perception and culture, and differential power. Indeed, in some ways these mechanisms simply reproduced the very problems that they were designed to overcome. Consequently, inter-agency collaboration remained elusive.

The prospect that a new and alien institution could be grafted onto the State Department without opposition from its turf-conscious bureaucracy, for example, was always utopian. Alternatively, military-based solutions did not look beyond its interest in counter-insurgency. As a result, initiatives from the military 
establishment aimed to replace rather than work with civilian agencies. The Provincial Reconstruction Teams epitomized the military's tendency to dominate proceedings, rather than cooperate with the civilian branches. Other governmentbased enterprises initiated by counter-bureaucracy, Congress and the National Security Council, became conduits for the pursuit of narrow sectional interests, thus undermining whatever improvements in inter-agency coherence they may have first promised.

Individuals who extolled the benefits of cooperation were often insincere. Those who genuinely believed in the necessity of intra-agency collaboration were treated as pariahs. Meanwhile, solutions for intragovernmental discord that were devised in academia and think-tanks underestimated the complex and entrenched barriers the US bureaucracy erected against an integrated approach to nation-building.

These barriers continue to be felt today. While this study has only covered the period up until 2010, there is little evidence to suggest that much has changed over the intervening four years. President Barrack Obama implemented the surge in 2009 , which resulted in an increase in resources, funding and manpower for what he called 'the good war'. But the surge did not lead to a more concerted whole-ofgovernment approach. Criticism of US nation-building in Afghanistan continued unabated in the media and academia, and no feasible plan has been devised for its continuation in the wake of the US withdrawal. ${ }^{6}$ In fact, it is no exaggeration to say that the US public, and by extension its politicians, bureaucrats and soldiers, would rather forget the fiasco of Afghanistan than learn from it. Nowhere is this more salient than in the foreign policy bureaucracy itself. The same fractured interests, conflicting perceptions, incompatible cultures and differential powers that made effective nation-building all but impossible in Afghanistan, now make understanding the experience even more conflicted and opaque than it otherwise would be, as bureaucratic factions try to pass the blame for collective failings.

Bureaucratic politics was not the cause of nation-building failure and it must be considered within the context of the broader range of problems that were mentioned at the beginning of this study. Up till now, much of the scholarly and media attention has been focused on the role of the Bush Administration, strategic ambiguity, the fragmented policies of the international community and Afghanistan's historical, cultural and political nuances as factors in US shortcomings there. By contrast, this study has sought to provide an account of the Afghanistan nationbuilding experience that highlights the divisions within the US state itself. It can be concluded that bureaucratic conflict significantly hampered the capability of the US to engage in effective nation-building. The lessons of this experience, unfortunately, are likely to be applicable in other foreign policy situations. 


\section{Bibliography}

\section{Books and Journal Articles}

Abi Amiri, Mohammad. "Road Reconstruction in Post-Conflict Afghanistan: A Cure or a Curse?", International Affairs Review, 11:2 (2013), 9.

Adams, Gordon. "The Office of Management and Budget: The President's Policy Tool", in Roger George and Harvey Rishikof, The National Security Enterprise: Navigating the Labyrinth, Washington DC: Georgetown University Press, 2001.

Ali, Tariq. Bush in Babylon: The Recolonization of Iraq, London: Verso, 2004.

- "Mirage of a Good War", in Nick Turse (ed.), The Case for Withdrawal from Afghanistan, London: Verso, 2010, 45-59.

Allen, T.S. "Addressing an Ignored Imperative, Rural Corruption in Afghanistan", Small Wars Journal, February 19, 2013.

Alley, Roderic. International Conflict and the International Community: Wars without End? London: Ashgate, 2004.

Allison, Graham and Halperin, Morton. "Bureaucratic Politics: A Paradigm and Some Policy Implications", in Raymond Tanter and Richard H. Ullmann, Theory and Policy in International Relations, Princeton: Princeton University Press, 1972.

Allison, Graham and Zelikow, Philip. Essence of Decision: Explaining the Cuban Missile Crisis, New York: Longman, 1999.

Anderson, Benedict. Imagined Communities: Reflections on the Origins and Spread of Nationalism, London: Verso, 1991, 1-9.

Arfsten, Darryl, et al. "Drug Use Among the Afghan National Police: A National Assessment", Military Medicine 177:1 (2012), 85-90.

Armitage, Richard, Interview with. PRISM, 1, 107.

Arreguin-Tofy, Ivan. "The Meaning of 'State Failure': Public service, public servants, and the contemporary Afghan State”, International Area Studies Review 15:3 (2012), 263-278.

Auerswald, David, and Saideman, Stephen. NATO in Afghanistan: Fighting Together, Fighting Alone, Princeton: Princeton University Press, 2014.

Bacevich, Andrew. American Empire: The Realities and Consequences of US Diplomacy, Cambridge: Harvard University Press, 2003. . (ed.) The Imperial Tense: Prospects and Problems of American Empire, Chicago: Ivan R. Dee, 2003.

—. The New American Militarism, New York: Oxford University Press, 2005.

- The Limits of Power: The End of American Exceptionalism, New York: Metropolitan Books, 2008. 
Washington Rules: America's Path to Permanent War, New York: Metropolitan books, 2010.

Baker, Pauline. "Forging a US Policy Toward Fragile States", PRISM 1:2 (2009), 69-84.

Barfield, Thomas. "An Islamic State is a State Run by Good Muslims: Religion as a Way of Life and not Ideology in Afghanistan", in Robert Hefner, Remaking Muslim Politics: Pluralism, Contestation, Democratization, Princeton: Princeton University Press, 2005, 215-221.

- "Culture and Custom in Nation-Building: Law in Afghanistan", Maine Law Review, 6:2 (2008), 348-373.

Barnard, Chester. The Functions of the Executive: 30th Anniversary Edition, Cambridge: Harvard University Press, 1971.

Barno, David. "Fighting the 'Other War', Counter-Insurgency Strategy in Afghanistan, 2003-2005”, Military Review, September-October (2007).

Barreua, Bernard. "Lessons from USDA in Iraq and Afghanistan", PRISM 1:3 (2010), $1-3$.

Bate, Robert. The Blind Hydra: USAID Policy Fails to Control Malaria, Washington DC: American Enterprise Institute for Public Policy Research, 2005.

Baumann, Andrea. "Clash of Organizational Cultures? The Challenge of Integrating Civilian and Military Efforts in Stabilization Operations", Rusi, 153:6 (2008), 70-73.

Beetham, David. The Legitimation of Power, London: Palgrave Macmillan, 1991.

Bendix, Reinhard. Nation-building and Citizenship: Studies of Our Changing Social Order, Berkeley: University of California Press, 1964.

Bendor, Jonathan and Hammond, Thomas. "Re-thinking Allison's model", American Political Science Review, 86:2 (1992), 301-322.

Benjamin, Mark and Slavin, Barbara. 'Ghost Soldiers: The Pentagon's Decade-Long Struggle to Win Hearts and Minds through Civil Affairs', The Center for Public Integrity, February 6, 2011.

Bennis, Phyllis. US Foreign Policy and the War on Terrorism, New York: Arris Books, 2003.

Berger, Mark. "From Nation-Building to State-Building: The Geo-Politics of Development, the Nation-State System and the Changing Global Order", Third World Quarterly, 27:1 (2006), 5-25.

Berntsen, Gary and Pezzullo, Ralph. Jawbreaker: The Attack on Bin Laden and Al-Qaeda, New York: Three Rivers Press, 2005.

Binnendijk, Hans and Johnson, Stuart (eds). Transforming for Stabilization and Reconstruction Operations, Washington DC: National Defence University Press, 2004.

Blackwell, Robert. "Plan B in Afghanistan: Why De Facto Partition is the Least Bad Option”, Foreign Affairs, January/February, 2011.

Bloomfield, Lincoln. "From Ideology to Program to Policy: Tracking the Carter Human Rights Policy", Journal of Political Analysis and Management, 2:1 (1982).

Bonn, Scott A. Mass Deception: Moral Panic and the US War on Iraq, Piscataway: Rutgers University Press, 2010.

Bowen, Stuart. "No More Adhocracies Reforming the Management of Stabilization and Reconstruction Operations", PRISM, 3:2 (2011), 3-18.

Bradley, Rusty. Lions of Kandahar, New York: Bantam Books, 2011.

Breuilly, John. Nationalism and the State, Manchester: Manchester University Press, 1973. Briggs, Ellis. "Farewell to Foggy Bottom: The Recollection of A Career Diplomat", in Morton Halperin, Bureaucratic Politics and Foreign Policy (Washington DC: The Brookings Institution, 1974), 38. 


\section{Bibliography}

Brinkley, Joel. "Money Pit: The Monstrous Failure of US Aid to Afghanistan", World Affairs, January/February, 2013.

Burke, Edward. "Leaving the Civilians Behind: The Soldier-Diplomat in Afghanistan and Iraq", PRISM, 1:2 (2010), 30-32.

Bush, George, Decision Points, New York: Random House, 2010.

Caldwell, Dan. Vortex of Conflict: US Policy Toward Afghanistan, Pakistan and Iraq, Stanford: Stanford University Press, 2011.

Campbell, John. The Foreign Affairs Fudge Factory, New York: Basic Books, 1971.

Carafano, James. "Five Missteps in Interagency Reform - And What to Do About Them", PRISM, 2:3 (2011), 115-124.

Carreua, Bernard. "Lessons From USDA in Iraq and Afghanistan", PRISM, 1:3 (2010), $139-150$.

Carter, James. Inventing Vietnam: The United States and State-Building, 1954-1968, Cambridge: Cambridge University Press, 2008.

Chatterjee, Pratap. "Paying off the Warlords: Anatomy of a Culture of Corruption", in Nick Turse (ed.), The Case for Withdrawal from Afghanistan, New York: Verso, 2010.

Chandrasekaran, Rajiv. Little America: The War Within the War for Afghanistan, London: Vintage, 2013.

Chayes, Sarah. The Punishment of Virtue: Inside Afghanistan After the Taliban, New York: Penguin Books, 2007.

Chesterman, Simon. You, The People; The United Nations, Transitional Administration and State-Building, New York: Oxford University Press, 2004.

Chouvy, Pierre. Opium: Uncovering the Politics of Poppy, London: IB Tauris, 2009.

Civic, Melanne and Carreau, Bernard. "Building a Civilian Lessons Learned System", PRISM, 1:2 (2010), 138-139.

Clifford, Garry. "Bureaucratic Politics", in Michael Hogan and Thomas Paterson, Explaining the History of American Foreign Relations, New York: Cambridge University Press, 2004.

Cobane, Craig. "Provincial Reconstruction Teams and Security Assistance: Comments on an Evolving Concept", Journal of International Security Assistance Management, 27:4 (2005), 91-98.

Coburn, Noah and Larson, Anna. Derailing Democracy in Afghanistan, Elections in an Unstable Political Landscape, New York: Columbia University Press, 2014.

Cohen, Raphael. “A Tale of Two Manuals”, PRISM, 2:1 (2011), 87-100.

Cohen, Warren. The Cambridge History of American Foreign Relations, Volume IV: America in the Age of Soviet Power 1945-1991, Cambridge: Cambridge University Press, 1993.

Cordesman, Anthony. The War after the War: Strategic Lessons of Iraq and Afghanistan, Santa Monica: RAND Corporation, 2003.

- The Ongoing Lessons of Afghanistan: Warfighting, Intelligence, Force Transformation, and Nation Building, Washington DC: Center for Strategic and International Studies, 2005.

- Afghan National Security Forces: What Will it Take to Implement the ISAF strategy, Washington DC: Center for Strategic and International Studies, 2010.

Courter, Jeff. Afghan Journal: A Soldier's Year in Afghanistan, Illinois: Independent Publishing Platform, 2008.

Crane, Conrad. "Draining Swamps and Transplanting Values: Nation-Building and the American Military", in David Forsythe, Patrice McMahon and Andrew Wedeman (eds), American Foreign Policy in a Globalized World, New York: Routledge, 2006. 
Crews, Robert and Tarzi, Amin (eds). The Taliban and the Crisis of Afghanistan, Cambridge: Harvard University Press, 2008.

Cummings, Bruce, Abrahamian, Ervand and Maoz, Moshe. Inventing the Axis of Evil: The Truth About Iran, North Korea and Syria, New York: New Press: 2004.

Daalder, Ivo and Destler, I.M. In the Shadow of the Oval Office: Profiles of the National Security Advisers and the Presidents They Served - from JFK to George W. Bush, New York: Simon and Schuster, 2011.

Daalder, Ivo and Lindsay, James. America Unbound: The Bush Revolution in Foreign Policy, New Jersey: Wiley, 2005.

Danner, Mark. "Rumsfeld's War and its Consequences Now", New York Review of Books, December 19, 2013.

Deutsch, Karl. "Nation-Building and National Development: Some Issues for Political Research", in Karl Deutsch and William Foltz, (eds), Nation-Building, New York: Atherton, 1963.

Dempsey, Gary. "Old Folly in a New Disguise: Nation-Building to Combat Terrorism", Policy Analysis, Report 429 (2002), 1-22.

_. "Fool's Errands: America's Recent Encounters with Nation-Building", Mediterranean Quarterly, 12:1 (2001), 57-80.

Destler, I.M. Presidents, Bureaucrats and Foreign Policy: The Politics of Organizational Reform, Princeton: Princeton University Press, 1974.

—. "How National Security Advisors See Their Role", in James McCormack (ed), The Domestic Sources of American Foreign Policy: Insights and Evidence, Maryland: Rowman \& Littlefield, 2012, 209-223.

Dobbins, James. "America's Role in Nation-Building: From Germany to Iraq", Survival, 45:4, 2003, 87-110.

. After the Taliban: Nation-Building in Afghanistan, Washington DC: Potomac Books, 2008.

Dobbins, James, et al. America's Role in Nation-Building: From Germany to Iraq, New York: RAND, 2003.

Dobbins, James et al. The Beginners Guide to Nation-Building, Santa Monica: RAND Corporation, 2007.

Dorronsoro, Gilles. Revolution Unending: Afghanistan 1979 to Present, New York: Colombia University Press, 2005.

Draper, Robert. Dead Certain: The Presidency of George W. Bush, New York: Free Press, 2007.

Drezner, Daniel. "Ideas, Bureaucratic Politics, and the Crafting of Foreign Policy", American Journal of Political Science, 44:4 (2000), 733-749.

Dupree, Louis. Afghanistan, Princeton: Princeton University, 1973.

Dziedzic, Michael and Seidl, Michael, Provincial Reconstruction Teams and Military Relations with International and Non-Governmental Organizations in Afghanistan, Washington DC: United States Institute of Peace, 2005.

Eccles, M.S. Beckoning Frontiers, New York: Knopf, 1951.

Eckstein, Harry. Internal War: Problems and Approaches, Glencoe: Free Press, 1964.

Eikenberry, Karl. "The Limits of Counter-Insurgency Doctrine in Afghanistan", Foreign Affairs, September/October (2013). http://www.foreignaffairs.com/articles/139645/karl-weikenberry/the-limits-of-counterinsurgency-doctrine-in-afghanistan (accessed 1/09/2014)

Einhorn, Jessica, Expropriation Politics, Washington DC: Lexington Books, 1974.

Elphinstone, Mountstuart, An Account of the Kingdom of Caubul, 2 Vols, Karachi, Oxford: Oxford University Press, 1972. 


\section{Bibliography}

Enterline, Andrew, Stull, Emily and Magagnoli, Joseph. "Reversal of Fortune? Strategy Change and Counterinsurgency Success by Foreign Powers in the Twentieth Century", International Studies Perspectives, 14:1 (2013), 176-198.

Epstein, Jason. "Leviathan”, New York Review of Books, May 1, 2003, 12.

Etzioni, Amitai, "A Self-Restrained Approach to Nation-Building by Foreign Powers", International Affairs, 80:1 (2004), 1-17.

Farrell, Graham and Thorne, John, "Where have all the Flowers Gone?: Evaluation of Taliban Crackdown against Opium Poppy Cultivation in Afghanistan", International Journal of Drug Policy, 16:2 (2005), 81-91.

Feith, Douglas. War and Decision: Inside the Pentagon at the Dawn of the War on Terrorism, New York: Harper, 2008.

Felbab-Brown, Vanda. "Afghanistan: When Counternarcotics Undermines Counterterrorism”, Washington Quarterly, 28:4 (2005), 55-72.

—. "Afghanistan Trip Report VI: Counternarcotics Policy in Afghanistan: A Good Strategy Poorly Implemented", Brookings Institute, Foreign Policy Trip Reports, May 10, 2012.

Feldman, Noah. What We Owe Iraq: War and Ethics of Nation-Building, Princeton: Princeton University Press, 2006.

Fenopetov, Vladamir. "The Drug Crime Threat to Countries Located on the Silk Road, China and Eurasia", Forum Quarterly, 4:1 (2006), 5-13.

Fitzgerald, Paul and Gould, Elizabeth. Invisible History: Afghanistan's Untold Story, San Francisco: City Light Books, 2009.

Frankel, Charles. High on Foggy Bottom: An Outsider's Inside View of the Government, New York: Harper \& Row, 1969.

Franks, Tommy. American Soldier, New York: Harper Collins, 2004.

Freeman, Lawrence. "Logic, Politics and Foreign Policy Processors: A Critique of the Bureaucratic Politics Model", International Affairs, 52 (1976), 434-449.

Fukuyama, Francis. State Building, Governance and World Order in the Twenty-First Century, London: Profile Books, 2004.

- "Nation-Building 101", The Atlantic Monthly, January-February, 2004, 159-162. (ed.) Nation-Building: Beyond Afghanistan and Iraq, Baltimore: John Hopkins University Press, 2006.

Gall, Carlotta, The Wrong Enemy: America in Afghanistan, 2001-2014, New York: Houghton Mifflin, 2014.

Gates, Robert, “A Balanced Strategy: Reprogramming the Pentagon for a New Age”, Foreign Affairs 88:1 (2009) 1-15.

- Duty: Memoirs of a Secretary of War, Croydon: WH Allen, 2014.

Gellner, Ernest. Nations and Nationalism, Oxford: Blackwell, 1983.

Gentile, Gian. "Misreading the Surge Threatens US Army's Conventional Capabilities", World Politics Review, March 4, 2008, http:/www.worldpoliticsreview.com/ articles/1715/misreading-the-surge-threatens-u-s-armys-conventional-capabilities

- Wrong Turn: America's Deadly Embrace of Counter-Insurgency, New York: Perseus, 2013.

George, Roger and Rishikof, Harvey (eds). The National Security Enterprise, Navigating the Labyrinth, Washington DC: Georgetown University Press, 2011.

Ghufran, Nasreen, “Afghanistan in 2007, A Bleeding Wound”, Asian Survey, 48:1 (2007), $154-160$.

Girardet, Edward. Killing the Cranes: A Reporter's Journey Through Three Decades of War in Afghanistan, Vermont: Chelsea Green, 2011. 
Giustozzi, Antonio. "Privatizing War and Security in Afghanistan: Future or Dead End?", Economics of Peace and Security Journal, 1:2 (2007).

Koran, Kalashnikov, and Laptop: The Neo-Taliban Insurgency in Afghanistan, New York: Columbia University, 2008. 2009 .

Glaze, John. Opium in Afghanistan: Reassessing US Counter-Narcotics Strategy, Carlisle: Strategic Studies Institute, 2007.

Goodhand, Jonathan. "Corrupting or Consolidating the Peace? The Drugs Economy and Post-conflict Peace-building in Afghanistan”, International Peacekeeping, 15:3 (2008), 405-423.

Goodson, Larry. Afghanistan's Endless War: State Failure, Regional Politics and the Rise of the Taliban, Seattle: University of Washington Press, 2001.

Gormley, William. "Counter-bureaucracies in Theory and Practice", Administration \& Society, 28:3 (1996), 275-298.

- Bureaucracy and Democracy: Accountability and Performance, Washington, DC: CQ Press College, 2013.

Gregorian, Vartan. The Emergence of Modern Afghanistan: Politics of Reform and Modernization, 1880-1946, Stanford: Stanford University Press, 1969.

Grote, Rainer. "Separation of Powers in the New Afghan Constitution", Heidelberg Journal of International Law, (2004), 897-915.

Hafvenstein, Joel. Opium Season: A Year on the Afghan Frontier, Guildford: Lyons Press, 2007.

Halperin, Morton. Bureaucratic Politics and Foreign Policy, Washington DC: The Brookings Institution, 1974.

Halperin, Morton, and Clapp, Priscilla, with Kanter, Arnold. Bureaucratic Politics and Foreign Policy, Washington DC: The Brookings Institution, 2006.

Halperin, Morton and Kanter, Arnold. "The Bureaucratic Perspective: A Preliminary Perspective', in Halperin and Kanter (eds), Readings in American Foreign Policy: A Bureaucratic Perspective, Boston: Little, Brown, 1973.

Hammond, Thomas. Red Flag Over Afghanistan: The Communist Coup, the Soviet Invasion, and the Consequences, Boulder: Westview Press, 1984.

Hammond, Thomas and Knott, Jack. "Who Controls the Bureaucracy?: Presidential Power, Congressional Dominance, Legal Constraints, and Bureaucratic Autonomy in a Model of Multi-Institutional Policy-Making", The Journal of Law, Economics and Organization, 12:1 (1996), 119-166.

Hardesty, Michael and Ellis, Jason. Training for Peace Operations: The U.S. Army Adapts to the Post-Cold War World, Washington DC: US Institute of Peace, 1997.

Harr, John. The Professional Diplomat, Princeton: Princeton University Press, 1969.

Hastings, Michael. The Operators, The Wild and Terrifying Inside Story of America's War in Afghanistan, London: Orion Books, 2012.

Hernandorena, Carlos. "US Provincial Reconstruction Teams in Afghanistan, 2003-2006: Obstacles to Interagency Cooperation", in Joseph Cerami and Jay Boggs (eds), The Interagency Counterinsurgency Warfare: Stability, Security, Transition, and Reconstruction Roles, Washington DC: Strategic Studies Institute, 2007, 121-171.

Hilsman, Roger. "The Foreign-Policy Consensus: An Interim Research Report”, Journal of Conflict Resolution, 3:4 (1959).

- The Politics of Policy Making in Defence and Foreign Affairs, Saddle River: Prentice Hall, 1990. 


\section{Bibliography}

Hobbes, Thomas. Leviathan, Lexington: Seven Treasures, 2009.

Holbrooke, Richard. "The Machine that Fails”, Foreign Policy, January 1, 1971.

Hosmer, Stephen. The Army's Role in Counterinsurgency and Insurgency, Santa Monica: RAND Corporation, 1990.

Hudson, Valerie. "Foreign Policy Analysis: Actor-Specific Theory and the Ground of International Relations", Foreign Policy Analysis, 1:1 (2005), 1-30.

Huma, Ahmed-Ghosh, "A History of Women in Afghanistan: Lessons Learnt for the Future or Yesterdays and Tomorrow: Women in Afghanistan", Journal of International Women's Studies, 4:3 (2003), 1-14.

Huntington, Samuel. The Soldier and the State: The Theory and Politics of Civil-Military Relations, Cambridge: Harvard University Press, 1957.

- The Common Defence: Strategic programs in national politics, New York: Columbia University Press, 1991.

Ignatieff, Michael. Empire Lite: Nation-building in Bosnia, Kosovo and Afghanistan, London: Vintage, 2003.

Inderfurth, Karl and Johnson, Loch (eds). Fateful Decisions, Inside the National Security Council, New York: Oxford University Press, 2004.

Ingalls, James. "The New Afghan Constitution: A Step Backwards for Democracy", Foreign Policy in Focus, March 13, 2004, 1-32.

Ingalls, Jim and Kolhatkar, Sonali. US Solution to a US Problem, Common Dreams, October 7, 2004.

Jalali, Ali, Oakley, Robert and Hunter, Zoe, Combating Opium in Afghanistan, Washington DC: National Defence University, 2006.

Jankowski, Jacob E. Corruption, Contractors and Warlords in Afghanistan, New York: Nova, 2011.

Jenkins, Kate and Plowden, William. Governance and Nation-building: The Failure of International Intervention, Cheltenham: Edward Elgar, 2006.

Jennings, Ray Salvatore. The Road Ahead: Lessons in Nation Building from Japan, Germany, and Afghanistan, for Postwar Iraq, Washington DC: United States Institute of Peace, 2003.

Jensen, Eric and Pomeroy, Amy. "Afghanistan Lessons Learned: Army Rule of Law Operations", in Michael Schmitt (ed.), The War in Afghanistan: A Legal Analysis, International Law Studies, 85, 470.

Jervis, Robert. "Why Intelligence and Policy-makers Clash", in James McCormack (ed.), The Domestic Sources of American Foreign Policy: Insights and Evidence, Maryland: Rowman \& Littlefield, 2012, 267-285.

Johnson, Chalmers. The Sorrows of Empire: Militarism, Secrecy and the End of the Republic, New York: Metropolitan Books, 2004.

- Dismantling the Empire: America's Last Best Hope, New York: Metropolitan Books, 2010.

Johnson, Chris and Jolyom, Leslie. Afghanistan: The Mirage of Peace, London: Zed Books, 2005.

Johnson, Thomas. "The Taliban Insurgency and an Analysis of Shabnamah (night letters)", Small Wars and Insurgencies, 18:3 (2007), 317-344.

Jones, Seth. In the Graveyard of Empires: America's War in Afghanistan, New York: W.W. Norton \& Company, 2010.

Jorgensen, Eric. "Greater than the Sum of its Parts: Putting Inter into Inter-Agency" PRISM, 2:2 (2011), 29-41. 
Kaarbo, Juliet. "Power Politics in Foreign Policy: The Influence of Bureaucratic Minorities", European Journal of International Relations, 4:1 (1998), 67-97.

Kandor, Jodi. "Hoolbrooke: A Larger Than Life Statesman", World Security Network, February 19, 2009.

Kane, Tim. Bleeding Talent: How the US Military Mismanages Great Leaders and Why it's Time for a Revolution, New York: Palgrave Macmillan, 2012.

Kaplan, Fred, The End of the Age of Petraeus: The Rise and Fall of Counterinsurgency, Washington DC: Council of Foreign Relations, 2013.

Kapstein, Ethan. "Do Three D's Make An F?: The Limits of Defence, Diplomacy and Development", PRISM, 1:3 (2010), 21-26.

Katz, Richard. Democracy and Elections, New York: Oxford University Press, 1997.

Katzman, Kenneth. "Afghanistan: Elections, Constitution and Government", in Carey Gladstone, Afghanistan Issues: Security, Narcotics and Political Currents, New York: Nova Science Publishers, 2007.

Kaufman, Herbert. The Administrative Behavior of Federal Bureaucracies, New York: Brookings Institution Press, 1981.

Kilcullen, David. The Accidental Guerrilla: Fighting Small Wars in the Midst of a Big One, New York: Oxford University Press, 2009.

Kinzer, Stephen. Overthrow: America's Century of Regime Change from Hawaii to Iraq, New York: Times Books, 2010.

Koontz, Christopher N. Enduring Voices: Oral Histories of the US Army Experience in Afghanistan 2003-2005, Washington DC: Center of Military History, 2008.

Kopp, Harry and Gillespie, Charles. Career Diplomacy: Life and Work in the Foreign Service, Washington DC: Georgetown University Press, 2011.

Kozak, David. "The Bureaucratic Politics Approach: The Evolution of the Paradigm", in David Kozak and James Keagle (eds), Bureaucratic Politics and National Security: Theory and Practice, New York: Lynne Rienner, 1988.

Kralev, Nicholas. America's Other Army: The US Foreign Service and 21st Century Diplomacy, CreateSpace Independent Publishing Platform, 2012.

Krasner, Stephen. "Are Bureaucracies Important? (Or Allisson Wonderland)", Foreign Policy, 7 Summer, 1972, 1917-1959.

Latham, Michael. Modernization as Ideology: American Social Science and "Nationbuilding” in the Kennedy Era, Chapel Hill: University of North Carolina Press, 2000.

Lawson, Stephanie. International Relations, Cambridge: Polity, 2003.

Lee, Greg. Global Drug Enforcement, London: CRC Press, 2004.

LeoGrande, William, Our Own Backyard: The United States in Central America, 19771992, Chapel Hill: University of North Carolina Press, 1998.

Levi, Margaret. "A Model, a Method, and a Map: Rational Choice in Comparative and Historical Analysis", in Mark Irving Lichbach and Alan Zuckerman, Comparative Politics: Rationality, Culture and Structure, New York: Cambridge University Press, 1997, $19-42$.

Lewis, David. The Politics of Presidential Appointments: Political Control and Bureaucratic Performance, Princeton: Princeton University Press, 2008.

Lindenberg, Siegwart. "The Method of Decreasing Abstraction", in James Coleman and Thomas Fararo (eds), Rational Choice Theory: Advocacy and Critique, London: Sage, 1992.

Lipson, Charles. Standing Guard: Protecting Foreign Capital in the Nineteenth and Twentieth Centuries, Berkeley: University of California Press, 1985. 
Lombardi, Clark. The Challenges and Opportunities of Islamic Review: Lessons for Afghanistan from the Experiences of other Muslim Countries, Washington DC: United States Institute of Peace, 2011.

Loyn, David. In Afghanistan: Two Hundred Years of British, Russian and American Occupation, New York: Palgrave Macmillan, 2009.

Luehrs, Christoff, "Provincial Reconstruction Teams: A Literature Review" PRISM, 1:1 (2009), 95-102.

MacDonald, David. Drugs in Afghanistan: Opium, Outlaws and Scorpion Tales, London: Pluto Press, 2007.

Maley, William. The Foreign Policy of the Taliban, New York: Council on Foreign Relations, 2000.

- Rescuing Afghanistan, Sydney: UNSW Press, 2006.

- Stabilizing Afghanistan: Threats and Challenges, Washington DC: Carnegie Endowment for International Peace, 2008.

- The Afghanistan Wars, New York: Palgrave Macmillan, 2009.

Mandel, Ruth, "Structural Adjustment and Soap Opera, A Case of a Development Project in Central Asia", Central Asian Survey, 18:4 (1998), 629-638.

Mann, James. Rise of the Vulcans: The History of Bush's War Cabinet, New York: Viking, 2004.

Markel, Wade, et al. Developing US Army Officers' Capabilities for Joint Interagency Intergovernmental and Multinational Environments, Washington DC: RAND, 2011.

Marsden, Peter. The Taliban: War and Religion in Afghanistan, London: Zed Books, 2002.

Marshal, Joshua. "Remaking the World: Bush and the Neoconservatives", Foreign Affairs, 82:6 (2003).

Martins, Mark. "No Small Change of Soldiering: The Commander's Emergency Response Program in Afghanistan and Iraq", The Army Lawyer, February, 2004, 1-20.

Maynard, Edwin. "The Bureaucracy and Implementation of US Human Rights Policy", Human Rights Quarterly, 11:2 (1989), 175-248.

McCoy, Alfred. The Politics of Heroin, CIA Complicity in the Global Drug Trade, Chicago: Lawrence Hill, 2003.

McKinlay, Alan and Starkey, Ken. "The Velvet Grip: Managing Managers in the Modern Corporation", in Alan McKinlay and Ken Starkey, Foucault, Management and Organization Theory, London: Sage, 1998.

McNerney, Michael. "Stabilization and Reconstruction in Afghanistan: Are PRTs a Model or a Muddle?" Parameters, 35:4, (2006), 32-46.

Meese, Michael and Wilson, Isaiah. "The Military: Forging a Joint Warrior Culture", in Roger George and Harvey Rishikof, The National Security Enterprise: Navigating the Labyrinth, Washington DC: Georgetown University Press, 2001, 117-139.

Miles, Renanah, "The State Department, USAID, and Flawed Mandate for Stabilization and Reconstruction", PRISM, 3:1 (2011), 37-46.

Miller, Paul. Armed State Building: Confronting State Failure 1898-2012, Cornell: Cornell University Press, 2013.

Mills, Greg and Mclay, Ewen. "A Path to Peace in Afghanistan: Revitalizing Linkage in Development, Diplomacy and Security", Orbis, 55:4 (2011), 600-612.

Mills, Nick. Karzai: The Failing American Intervention and the Struggle for Afghanistan, New Jersey: Jon Wiley \& Sons, 2007.

Minear, Larry. The US Citizen-Soldier and the Global War on Terror: The National Guard Experience, Medford: Feinstein International Center, 2007. 
Moens, Alexander. The Foreign Policy of George W. Bush: Values, Strategy and Loyalty, London: Ashgate, 2003.

Morrow, James. "A Rational Choice Approach to International Conflict", in Nehemia Geva and Alex Mintz (eds), Decision-Making on War and Peace: The Cognitive-Rational Debate, Boulder: Lynne Rienner, 1997, 12-18.

Muscate, Robert. "Lessons from Post-Conflict Aid Experience", in Montgomery and Rondinelli, Beyond Reconstruction in Afghanistan, New York: Palgrave Macmillan, 2004, 93-100.

Myers, Richard. Report of Interview in PRISM, 2:1 (2011), 152-59.

Nachbar, Thomas. "Counter-Insurgency, Legitimacy and the Rule of Law", Parameters, Spring (2012), 27-38.

Nagal, John. Counterinsurgency Field Manual, Chicago: University of Chicago Press, 2007.

Natsios, Andrew. "Five Debates on International Development: The US Perspective", Development Policy Review, 24:2 (2006), 131-139.

_ . "USAID in the Post-Cold War World", Foreign Service Journal, June, 2006.

. "Time Lag and Sequencing Dilemmas of Post-Conflict Reconstruction", PRISM, 1:1 (2009), 63-75.

The Clash of the Counter-Bureaucracy and Development, Washington DC: Center for Global Development, 2010.

- "The Nine Principles of Reconstruction and Development", Parameters, Autumn (2005), 4-20.

Nawa, Fariba. Opium Nation: Child Brides, Drug Lords, and One Woman's Journey through Afghanistan, New York: Harper, 2011.

Neumann, Ronald. The Other War: Winning and Losing Afghanistan, Washington DC: Potomac Books, 2009.

Neustadt, Richard. Presidential Power, New York: Free Press, 1991.

- "The President's Power to Persuade", in Peter Hays, Brenda Vallance and Alan Tassel. American Defence Policy, Maryland: John Hopkins University Press, 1997, 74-81.

Newell, Richard. The Politics of Afghanistan, New York: Cornell University Press, 1972.

Newell, Nancy and Newell, Richard. The Struggle for Afghanistan, New York: Cornell University Press, 1982.

O'Hanlon, Michael and Sherjan, Hassina. Toughing it Out in Afghanistan, Washington DC: Brookings Institution, 2010.

Olsen, Howard and Davis, John. Training U.S. Army Officers for Peace Operations: Lessons from Bosnia, Washington DC: US Institute of Peace Press, 1999.

Olson, Lara and Gregorian, Hrach. "Civil-Military Coordination: Challenges and Opportunities in Afghanistan and Beyond", Journal of Military and Strategic Studies, 10:1 (2007), 1-12.

Orton, James Douglas with Lamb, Christopher. "Interagency National Security Teams: Can Social Science Contribute?" PRISM, 2:2 (2010), 47-64.

Ottaway, Marina. "Nation-Building”, Foreign Policy, 132, Sept-Oct (2002), 16-24.

- "Rebuilding State Institutions in Collapsed States", Development and Change, 33:5 (2002), 1001-1023.

Oye, Kenneth, "Cooperation Under Anarchy: Hypothesis and Strategies", in Kenneth Oye (ed.), Cooperation Under Anarchy, Princeton: Princeton University Press, 1986.

Paris, Roland. "Peace Building and the Limits of Liberal Internationalism", International Security, 22:2 (1997), 54-89. 


\section{Bibliography}

. "Understanding the "Coordination Problem" in Postwar Statebuilding", in Roland Paris and Timothy Sisk. The Dilemmas of Statebuilding: Confronting the Contradictions of Postwar Peace Operations, New York: Routledge, 2009.

Perret, Geoffrey. Commander in Chief: How Truman, Johnson and Bush Turned a Presidential Power into a Threat to America's Future, New York: Straus and Giroux, 2007.

Perito, Robert. "The US Experience with Provincial Reconstruction Teams in Afghanistan", United States Institute of Peace Special Report, Special Report 152, October (2005).

- Oral Histories Project on Stability Operations: Provincial Reconstruction Teams, Washington DC: United States Institute of Peace, 2006.

Porch, Douglas. Counter-Insurgency: Exposing the Myths of the New Way of War, New York: Cambridge University Press, 2013.

Poullada, Leon. Reform and Rebellion in Afghanistan, 1919-1929: King Amanullah's Failure to Modernize a Tribal Society, New York: Cornell University Press, 1973.

Prestowitz, Clyde. Rogue Nation: American Unilateralism and the Failure of Good Intentions, New York: Basic Books, 2003.

Priest, Dana. The Mission: Waging War and Keeping Peace with America's Military, New York: WW Norton, 2003.

Pulparampil, John. Models of Nation-building: A Critical Appraisal, New Delhi: NV Publications, 1975.

Rashid, Ahmed. “The Taliban: Exporting Extremism”, Foreign Affairs, November/December, 1999.

- Descent into Chaos: The United States and the Failure of Nation-Building in Pakistan, Afghanistan and Central Asia, New York: Penguin, 2008.

- Taliban: Militant Islam, Oil and Fundamentalism in Central Asia, London: IB Tauris, 2010.

"A Path Paved with Pitfalls", Far East Economic Review, October 4, 2011.

Reiner, Robert. The Politics of the Police, Oxford: Oxford University Press, 2010.

Rhodes, Edward, "Do Bureaucratic Politics Matter? Some Discomfiting Findings from the Case of the U.S. Navy", World Politics, 47:1 (1994), 1-41.

Rice, Condoleezza. "Rethinking the National Interest: American Realism for a New World", Foreign Affairs 87:4 (2008), 2-27.

Ricks, Thomas. The Gamble: General Petraeus and the American Military Adventure in Iraq, London: Penguin, 2009.

Risen, James. State of War: The Secret History of the CIA and the Bush Administration, New York: Free Press, 2006.

Roberts, Jeffery. The Origins of Conflict in Afghanistan, Connecticut: Westport, 2003.

Robichaud, Carl, "Remember Afghanistan? A Glass Half Full, On the Titanic", World Policy Journal, 23:1 (2006), 17-24.

Rohde, David. "The lost mission", in Derek Challet and Samantha Power. The Unquiet American, New York: Perseus Books (2011), 282-296.

Rohrlich, Paul. "Economic Culture and Foreign Policy: The Cognitive Analysis of Economic Policy-making”, International Organization, 41:1 (1987), 61-92.

Rondinelli, Dennis. "Economic Growth and Development Policy in Afghanistan: Lessons from Experience in Developing Countries", in John Montgomery and Dennis Rondinelli (eds), Beyond Reconstruction in Afghanistan: Lessons from Development Experience, New York: Palgrave Macmillan, 2004, 115-130.

Rosati, Jerel. "Developing a Systematic Decision-making Framework: Bureaucratic Politics in Perspective", World Politics, 33:2 (1981), 234-52. 
Rothkopf, David. Running the World, The Inside Story of the National Security Council and the Architects of American Power, New York: Perseus, 2005.

Roy, Olivier. Islam and Resistance in Afghanistan, New York: Cambridge University Press, 1990.

Rubin, Barnett. Secrets of State: The State Department and the Struggle over Foreign Policy, New York: Oxford University Press, 1987.

—. "Crafting a Constitution for Afghanistan", Journal of Democracy, 15:3 (2004), $5-19$.

Afghanistan's Uncertain Transition from Turmoil to Normalcy, Washington DC: Council on Foreign Relations, 2006.

. Counter-Narcotics to Stabilize Afghanistan: The False Promise of Crop Eradication, New York: Center on International Cooperation, 2008.

Rupp, Richard. "High Hopes and Limited Prospects: Washington's Security and NationBuilding Aims in Afghanistan", Cambridge Review of International affairs, 19:2 (2006), 286-296.

Rynning, Sten. NATO in Afghanistan: The Liberal Disconnect, Stanford: Stanford University Press, 2012.

Saikal, Amin. Modern Afghanistan: A History of Struggle and Survival, New York: IB Tauris, 2004.

Sands, Chris. "Chaos Central", in Nick Turse (ed.), The Case for Withdrawal from Afghanistan, London: Verso, 2010, 63-70.

Sarwari, Atiq and Crews, Robert. "Afghanistan and the Pax Americana", in Robert Crews and Amin Tarzi (eds), The Taliban and the Crisis of Afghanistan, Cambridge: Harvard University Press, 2008.

Schake, Kori. State of Disrepair: Fixing the Cultures and Practices of the State Department, Stanford: Hoover Institution Press, 2012.

Schanaubelt, Christopher. "Complex Operations and Interagency Operational Art", PRISM, 1:1 (2009), 37-50.

Scharf, Michael and Williams, Paul. Shaping Foreign Policy in Times of Crisis: The Role of International Law and the State Department Legal Advisor, New York: Cambridge University Press, 2010.

Schilling, Walter. "The Politics of National Defence", in Thomas Hammond, Walter Schilling and Paul Snyder (eds), Strategy, Politics and Defence Budgets, New York: Columbia Press, 1962, 21-26.

Schirch, Lisa. Civil Society-Military Relations in Afghanistan, Washington DC: United States Institute of Peace, 2010.

Schlesinger, Arthur. The Imperial Presidency, Boston: Houghton Mifflin, 2004.

Schoemaker, Paul J.H. "Strategic Decisions in Organizations: Rational and Behavioral Views", Journal of Management Studies, 30: 1 (1993), 107-129.

Schroen, Gary. First In: An Insiders Account of how the CIA Spearheaded the War on Terror in Afghanistan, New York: Random House, 2005.

Scott, Andrew. "The Department of State: Formal Organization and Informal Culture", International Studies Quarterly, 13:1 (1969), 1-18.

Sedra, Mark. "Security Sector Reform in Afghanistan: The Slide Toward Expediency", International Peacekeeping, 13:1 (2006), 94-110.

Seidman, H. Politics, Position and Power: The Dynamics of Federal Organization, New York: Oxford University Press, 1970.

Serchuk, Vance. Cop Out: Why Afghanistan Has No Police, Washington DC: American Enterprise Institute for Public Policy Research, 2006. 


\section{Bibliography}

Simon, Herbert. Administrative Behavior: A Study of Decision-Making Processes in Administrative Organization, New York: Free Press, 1997.

Sinno, Abdulkader. Organizations At War in Afghanistan and Beyond, New York: Cornell University Press, 2008.

Smith. Anthony. Nationalism: Theory, Ideology, History, Cambridge: Polity Press, 2001.

Smith, Dane. US Peacefare: Organizing American Peace-Building Operations, Washington DC: Center for Strategic and International Studies, 2010, 80-81.

Smith, Fredrick and Miller, Franklin. "The Office of the Secretary of Defence: Civilian Masters?" in Roger George and Harvey Rishikof, The National Security Enterprise: Navigating the Labyrinth, Washington DC: Georgetown University Press, 2001, 97-117.

Sniegoski, Stephen. Transparent Cabal: The Neo-Conservative Agenda, War in the Middle East and the National Interest of Israel, Virginia: Enigma, 2008.

Somit, Albert and Peterson, Steven. The Failure of Democratic Nation-Building: Ideology Meets Evolution, New York: Palgrave Macmillan, 2005.

Sorensen, Ted. Kennedy, New York: Harper \& Row, 1965.

Spanta, Rangin. "Afghanistan: Nation-Building in the Shadow of the Warlords and the 'War on Terror'", in Jochen Hippler (ed.), Nation-building, A Key Concept for Peaceful Conflict Transformation? London: Pluto Press, 2004.

Stapleton, Barbara. "A Means to an End? Why PRTs are Peripheral to the Bigger Political Challenges in Afghanistan”, Journal of Military and Strategic Studies, 10:1 (2007), $1-49$.

Steele, Dennis. "The Race to Win", ARMY, November 2003, 10-11.

Stephenson, Carolyn. "Nation-Building”, Beyond Intractability, January 2005.

Stephenson, Max. "Making Humanitarian Relief Networks More Effective: Operational Coordination, Trust and Sense Making", Disasters, 29:4 (2005), 337-350.

Stewart, Patrick. "The U.S. Response to Precarious States: Tentative Progress and Remaining Obstacles to Coherence" in Stefani Weiss (ed.), International Responses to Precarious States: A Comparative Analysis of International Strategies with Recommendations for Action by European Institutions and Member States, Washington DC: Center for Global Development, 2007.

Stewart, Patrick and Brown, Kaysie. Greater than the Sum of its Parts? Assessing 'Whole of Government'Approaches to Fragile States, New York: International Peace Academy, 2007.

Stockton, Nicholas. Strategic Coordination in Afghanistan, Kabul: Afghanistan Research and Evaluation Unit, 2002.

Stone, Deborah. Policy Paradox: The Art of Political Decision Making, New York: Norton \& Company, 2012.

Strachan, Hew. "The Lost Meaning of Strategy", Survival: Global Politics and Strategy, 47:3, 33-54.

Streeten, Paul. The Frontiers of Development Studies, New York: Palgrave Macmillan, 1980.

Sirat, A.S. "The Modern Legal System of Afghanistan", The American Journal of Comparative Law, 16:4 (1968), 563-569.

Suhrke, Astri and Borchgrevink, Kaja. "Negotiating Justice System Reform in Afghanistan", Crime, Law and Social Change, 1:2 (2009), 211-230.

Tenet, George. At the Center of the Storm: My Years at the CIA, New York: Harper Collins, 2007.

Terry, Lynn. "The Hybrid Regimes of Central America", Journal of Democracy, 6:5 (1995), 73. 
Thomas, Lowell. Beyond Khyber Pass, Long Riders Guild Press, 2001.

Tondini, Matteo. "Justice Sector Reform in Afghanistan: From a 'Lead Nation' Approach to a 'Mixed Ownership Regime'?" Transitional Studies Review, 15:4 (2009), 660-673.

Tremblay, Rodrigue. The New American Empire: Causes and Consequences for the United States and for the World, Haverford: Infinity, 2004.

Tupper, Benjamin. Greetings from Afghanistan: Send More Ammo, New York: Penguin, 2011.

Turse, Nick (ed.). The Case for Withdrawal from Afghanistan, London: Verso, 2010.

- "The 700 Military Bases: Black Sites in the Empire of Bases", in Nick Turse (ed.). The Case for Withdrawal from Afghanistan, London: Verso, 2010, 135-140.

Vandenbrouke, Lucien. "Anatomy of a Failure: The Decision to Land at the Bay of Pigs", Political Science Quarterly, 99:3 (1984), 471-491.

Von Hippel, Karin. "Democracy by Force: A Renewed Commitment to Nation-Building”, Washington Quarterly, 23:1 (2000), 95-112.

Warwick, Donald. A Theory of Public Bureaucracy, Cambridge: Harvard University Press, 1975.

Wawro, Geoffrey. Quicksand, America's Pursuit of Power in the Middle East, New York: Penguin Press, 2010.

Weber, Max. The Theory of Social and Economic Organization, New York: The Free Press, 1964.

- Economy and Society, Berkeley: University of California Press, 1978.

Welch, David. "The Organizational Process and Bureaucratic Politics Paradigms: Retrospect and Prospect”, International Security, 17:2 (1992), 112-146.

West, Bing. The Wrong War: Grit, Strategy, and the Way Out of Afghanistan, New York: Random House, 2011.

Williams, Brian Glyn. Afghanistan Declassified, A Guide to America’s Longest War, Philadelphia: University of Pennsylvania Press, 2012.

Wilson, James. Bureaucracy, What Government Agencies Do and Why They Do It, New York: Basic Books, 1989.

Wily, Liz. Land Rights in Crisis: Restoring Tenure Security in Afghanistan, Kabul: Afghanistan Research and Evaluation Unit, 2009.

. Looking for Peace on the Pastures: Rural Land Relations in Afghanistan, Kabul: Afghanistan Research and Evaluation Unit, 2009.

Wise, David and Ross, Thomas. The Invisible Government, New York: Random House, 1964.

Wood, Bernard. Development Dimensions of Conflict Prevention and Peace-Building: An Independent Study Prepared for the Emergency Response Division, New York: United Nations Development Program, 2003.

Woodward, Bob, Bush at War, New York: Simon \& Schuster, 2005.

Yetiv, Steve, Explaining Foreign Policy, US Decision-making in the Gulf Wars, Baltimore: John Hopkins University Press, 2011.

Yodsampa, Strimling. No One in Charge: A New Theory of Coordination and Analysis of US Civil-Military Coordination in Afghanistan 2001-2009, PhD Dissertation, Tufts University, 2011.

Zakheim, Dov. A Vulcan's Tale: How the Bush Administration Mismanaged the Reconstruction of Afghanistan, Washington DC: Brookings Institution Press, 2013.

Zalmay, Khalizad. “Anarchy in Afghanistan”, Journal of International Affairs, 51:1 (1997).

Zelizer, Julian. Arsenal of Democracy: The Politics of National Security-From World War II to the War on Terrorism, New York: Basic Books, 2010. 


\section{Bibliography}

\section{Newspaper Articles and NGO Reports}

Ajami, Fouad. "Richard Holbrooke: Kennedy Democrat", Wall Street Journal, December $15,2010$.

Akbar, Noorjahan. "Raped Afghan Women Have No Hope of Justice", Al-Jazeera, July 8, 2011.

Ambinder, Mark. "The Night Beat: What the Heck Was McChrystal Thinking?" The Atlantic, June 21, 2010.

Annan, Kofi. The Situation in Afghanistan and Its Implications for Peace and Security, Report of the Secretary-General, United Nations (A/61/326-S/2006/727), September 11, 2006.

Associated Press, "US to shift approach to Afghanistan drug trade", LA Times, June 28, 2009.

_ , "High Level Talks Held in Rome", The Seattle Times, September 18, 2010.

Baker, Aryn. "A Dam Shame: What a Stalled Hydropower Project Says About Failures in Afghanistan", Time, December 15, 2011.

BBC. "Aid Drops Target Civilians", October 7, 2001, http://news.bbc.co.uk/2/hi/south asia/1585554.stm (accessed 26/06/2011).

- "Embassies Raise Flags in Kabul", December 17, 2001.

—. "Why Many Afghans Opt for Taliban Justice", BBC World News, December 2, 2013.

Bearak, Barry. “As War Enters Classrooms, Fear Grips Afghans”, New York Times, July 10, 2007.

Bergen, Peter. Defeating the Attempted Global Jihadist Insurgency, New America Foundation, July $2008 \mathrm{http}: / /$ newamerica.net/node/8924

Beckley, Lieutenant Colonel. "Interview with Tvnportal”, Daily Motion. March 24, 2012.

Bhatia et al. "Minimal Investment, Minimal Results: The Failure of Security Policy in Afghanistan", Afghanistan Research and Evaluation Unit, June, 2004.

Blank, Stephen. "Beyond Manas: Russia's Game in Afghanistan”, Central Asia Caucus Analyst, February 11, 2009.

Boak, Josh. "US Funded Infrastructure Deteriorates Once Under Afghan Control, Report Says", Washington Post, January 4, 2001.

Boone, Jon. "Taliban Hardliners Spread out to Undermine Afghan Election", The Guardian, August 18, 2009.

"WikiLeaks Cable Portrays Karzai as Corrupt and Erratic", The Guardian, December 3, 2010.

- "US Cuts Put British-backed Afghan Hydropower Project in Doubt", The Guardian, December 13, 2011.

Borger, Julian. "Powell Loses Power over Pentagon”, The Guardian, December 11, 2001.

—. "New Direction for US in Afghanistan Following Richard Holbrooke Death", The Guardian, December 15, 2010.

Brahimi, Lakhdar. "Briefing to the Security Council”, United Nations, 13 November, 2001.

Brinkley, Joel. "Millions More Squandered by USAID in Afghanistan", World Affairs Journal, online blog, June 28, 2013. http://www.worldaffairsjournal.org/blog/joel-brinkley/ millions-more-squandered-usaid-afghanistan (accessed 28/6/2013).

Brinkley, Joel and Gall, Carlotta. "Rice Calls Afghans Inspiring, but Election is Delayed Again”, New York Times, March 18, 2005.

Brinkley, Joel and Ruhullah, Khapalwak. "Rice, Visiting Violent Afghanistan, Still Finds Political Progress", New York Times, October 13, 2005. 
Chayes, Sarah. "Care and Feeding of the Taliban", New York Times, July 9, 2006.

_ , "A Voice From Kandahar: Tangled in Red tape", New York Times, July 30, 2006.

Chivers, CJ, "As Funding Increases, Afghan Forces Range From Ragtag to Ready", New York Times, May 2, 2007.

_. "On Taliban Turf, Lines of Ailing Children", New York Times, December 12, 2007. 2008 .

_. "Afghan Police Earn Poor Grade for Marja Mission", New York Times, June 1, 2010.

Cloud, David. "Rumsfeld in Tajikistan, Urges Tough Stand against Taliban", New York Times, July 11, 2006.

Cloud, David and Gall, Carlotta. "U.S. Memo Faults Afghan Leader on Heroin Fight", New York Times, May 22, 2005.

Cooper, Helen. "NATO Chief Says More Troops are Needed in Afghanistan", New York Times, September 22, 2006.

Cooper, Helene and Zeleny, Jeff. "Obama warns Karzai to focus on Tackling Corruption”, New York Times, November 2, 2009 http://www.nytimes.com/2009/11/03/world/ asia/03afghan.html

Crawley, Vince. "Rumsfeld Wants Soldiers Off Afghanistan Rebuilding Teams", Army Times, 15 March, 2004.

Crisis Group Asia, Countering Afghanistan's Insurgency: No Quick Fixes, Report No123, November 2, 2006.

—, Reforming Afghanistan's Police, Report No. 138, August 30, 2007.

- Policing in Afghanistan: Still Searching for a Strategy: Briefing No. 85, December $18,2008$.

Dao, James. "Bush Sets Role for U.S. in Afghan Rebuilding", New York Times, April 18, 2002.

Dempsey, Judy. "General Calls Drugs Biggest Test for Afghans", International Herald Tribune, May 22, 2006.

Dillard, Paul. “ANCOP Graduates 321 New Officers”, Blackanthem Military News, July 1, 2009.

Dobbs, Michael. "With Albright, Clinton Accepts New US Role", Washington Post, December 8, 1996.

Fick, Nathaniel and Singh, Vikram. "Winning the Battle, Losing the Faith", New York Times, October 4, 2008.

Gall, Carlotta. "Afghans Accuse U.S. of Secret Spraying to Kill Poppies”, New York Times, February 27, 2005.

_. "16 Civilians Die as U.S. Troops Fire on Afghan Road", New York Times, March 5, 2005.

. "From the Rubble: A City of Old? Or All Shiny and New?" New York Times, June 27, 2005.

_. "Mood of Anxiety Engulfs Afghans as Violence Rises", New York Times, June 30, 2005.

—_. "Cheney and Afghan Milestone", New York Times, December 20, 2005.

__. "Panel Faults US Trained Afghan Police", New York Times, December 4, 2006.

_. "NATO's Afghan Struggle: Build, and Fight Taliban", New York Times, January 13, 2007. 
. "Building a Dam in a Bid to End Afghan Instability", New York Times, September 18, 2007. 2008.

, "Afghanistan Lacks $\$ 10$ billion in Aid Report Says", New York Times, March 26,

, "Hunger and Food Prices Push Afghanistan to the Brink", New York Times, May 16, 2008.

Gertz, Bill. "Rumsfeld Takes Dim View of US Peace-Keeping Role", Washington Times, February 27, 2002.

Ghali, Boutrous Boutrous. "An Agenda For Peace", Report of the Secretary General, A/47/277-s/24111, June 17, 1992.

Glanz, James and Rohde, David. "Panel Faults US-Trained Afghan Police", New York Times, December 4, 2006.

Golen, Ti and Schmitt, Eric. "A Growing Afghan Prison Rivals Bleak Guantanamo”, New York Times, February 26, 2006.

Gordon, Michael. "Policy Divisions: CIA sees Threat, Afghan Factions May Bring Chaos", New York Times, February 21, 2002.

Gordon, Michael. "US Backs Increase in Peacekeepers for Afghanistan", New York Times, August 30, 2002.

Graham, Nicholas. "Karl Eikenberry Papers: US Afghan Ambassador's Report Warned Against Troop Escalation", Huffingtonpost, April 5, 2010.

Hafvenstein, Joel. “Afghanistan's Drug Habit”, New York Times, September 20, 2006.

Hastings, Michael. "The Runaway General”, Rolling Stone, June 22, 2010.

Hedgpeth, Dana and Cohen, Sarah. "Money as a Weapon", Washington Post, August 11, 2008.

Hersh, Joshua. “Afghanistan's US funded Counter-Narcotics Tribunal Convicts Nearly All Defendants, Records Show", Huffington Post, June 10, 2012.

_. "Afghanistan: The Long and Winding Roads", Huffington Post, October 9, 2012.

Hoagland, Jim. "Poppies vs Power in Afghanistan", Washington Post, December 23, 2007.

Human Rights Watch. Afghanistan: Return of the Warlords, Human Rights Watch Briefing Paper, June, 2002.

Independent Task Force Co-sponsored by the Council on Foreign Relations and the Asia Society, “Are We Losing the Peace?” Council on Foreign Relations, June 2003.

Johnson, Casey. "Afghan Islamic Courts: A Pre-Taliban System with Post-2014 Potential”, New York Times, April 17, 2013.

Jones, Seth and Fair, Christine. Securing Afghanistan, Getting on Track: United States Institute of Peace Working Paper, United States Institute of Peace, January 23, 2009.

King, Laura. "Change on Afghan Border", Los Angeles Times, July 2, 2009.

Koehler, J. and Zurcher, C. Conflict Processing and the Opium Poppy Economy in Afghanistan, Project for Alternative Livelihoods in Eastern Afghanistan, internal document No. 5. Jalalabad/ Berlin, August 2005.

Kreisler, Harry. "Interview with James Dobbins", Conversations with History, Institute of International Studies, UC Berkeley, May 5, 2005.

Kristof, Nicholas. "What Holbrooke Knew", New York Times, May 14, 2001.

Kurata, Phillip, Former US Envoy to Afghanistan Reviews Bonn Agreement Success, IIP Digital US Embassy, October 5, 2006.

Lander, Mark. "Post-Holbrooke Question: What Now?", New York Times, December 14, 2010.

Lau, Martin. Afghanistan's Legal System and its Compatibility with Human-Rights Standards, International Commission of Jurists, 2002. 
Londoño, Ernesto. "Survey of Afghans Points to Rampant Corruption in Government", Washington Post, July 8, 2011.

_. "As U.S. Withdraws from Afghanistan, Poppy Trade it Spent Billions Fighting Still Flourishes", Washington Post, November 13, 2013.

Lucia, Jeremie. "Thoughts of a Landlocked Sailor: Mission in Afghanistan, Dispatches from America's 'Other' War”, New York Times, November 21, 2006.

Lynch, Colum. "Annan Urges Cautious Response", Washington Post, September 25, 2001

Maas, Peter. "Gul Agha Gets his Province Back”, New York Times, January 6, 2002.

Macaskill, Ewan. "US Claims 45 Nations in "Coalition of Willing'", The Guardian, Wednesday, March 19, 2003.

_. "McChrystal and Eikenberry Present United Front After Troop Surge Row", The Guardian, December 9, 2009.

Mazzetti, Mark and Schmitt, Eric. "US Study Is Said to Warn of Crisis in Afghanistan', New York Times, October 8, 2008.

McGirk, Tim. "The Taliban on the Run", Time, March 28, 2005.

McNeil, Donald D. "Could Afghan Poppies be Pain Killers for the Poor?", New York Times, October 14, 2007.

Motlagh, Jason. "\$5 Billion For Afghans Still Unspent”, Washington Times, March 25, 2009.

New York Times, "Laura Bush Carries Pet Causes to Afghans”, March 31, 2005.

—. "Pentagon Sees Aggressive Antidrug Effort in Afghanistan", March 25, 2005.

. "Fearful of Alienating Afghans, US Turns a Blind Eye to Opium”, March 21, 2010.

Nissenbaum, Dion. "Roads to Nowhere: Program to Win Over Afghans Fails", Wall Street Journal, February 10, 2012.

Nordland, Rod. "US Turns a Blind Eye to Opium in Afghan Town", New York Times, March 20, 2010.

Packer, George. "The Last Mission: Richard Holbrooke's Plan to Avoid the Mistakes of Vietnam and Afghanistan", The New Yorker, September 28, 2009.

Partlow, Joshua. "Tensions Between Eikenberry, McChrystal will be Focus of their Washington Visit”, Washington Post, May 9, 2010.

Partlow, Joshua and Constable, Pamela. "Accusations of Vote Fraud Multiply in Afghanistan", Washington Post, August 28, 2009.

Paxman, Jeremy. Interview with Colin Powell, BBC, September 21, 2000.

Pei, Minxin and Kasper, Sara. "Lessons from the Past: The American Record on Nation Building", Policy Brief, Carnegie Endowment for International Peace 24 May 2003, Carnegie Endowment for International Peace, 2003.

Peterson, Scott. "In Afghanistan, Troops Tackle Aid Projects - and Skepticism", Christian Science Monitor, October 2, 2006.

Purdum, Todd. "Bush Offers Afghanistan U.S. Help for Training of Military and Police", New York Times, January 29, 2002.

Rice, Susan. "The New National Security Strategy: Focus on Failed States", Brookings Policy Brief Series, February, 2003.

Risen, James. "Poppy Fields are now a Front Line in Afghan War", New York Times, May 16, 2007.

Rohde, David. "Little America: An Afghan Town, an American Dream and the Folly of For-Profit War", Reuters, June 1, 2012.

Rohde, David and Gall, Carlotta. "Delays Hurting U.S. Rebuilding in Afghanistan", New York Times, November 5, 2005. 
Rohde, David and Sanger, David. "How a 'Good War' in Afghanistan Went Bad", New York Times, August 12, 2007.

Rohde, David. "Richard Holbrooke's Last Mission in Afghanistan", The Daily Beast, November 26, 2011.

Royal United Services Institute for Defence and Security Studies and the Foreign Policy Research Institute. Reforming Afghanistan's National Police, Royal United Services Institute for Defence and Security Studies (London) and the Foreign Policy Research Institute (Philadelphia), joint Report, November, 2009.

Rubin, Allisa and Gall, Carlotta. "Widespread Fraud seen in Latest Afghan Elections", New York Times, September 24, 2010.

Rubin, Allisa and Risen, James. "Costly Afghanistan Road Project is Marred by Unsavory Alliances”, New York Times, May 1, 2011.

Rubin, Allisa and Rosenberg, Matthew. "US Efforts Fail to Curtail Trade in Afghan Opium”, New York Times, May 26, 2012.

Rubin, Barnett and Rashid, Ahmed. "SOS from Afghanistan”, Wall Street Journal, May 29, 2003.

Rubin, Elizabeth. "Taking the Fight to the Taliban”, New York Times, October 29, 2006.

Rupert, James. "US Loses Ground as Afghanistan Erodes", The Seattle Times, September 20, 2007.

Schmitt, Eric. "Where Armies Must be Built, it's Slow (Iraq) and Even Slower (Afghanistan)", New York Times, September 25, 2005.

_. "Many Sources Feed Taliban's War Chest", New York Times, October 18, 2009.

- "US Envoy's Cables Show Worries on Afghan Plans", New York Times, January $25,2010$.

Scrutton, Alastair. "Attacks on Aid Challenge Afghan Reconstruction”, Reuters, September 18, 2008.

Semple, Kirk and Golden, Tim. "Afghans Pressured by U.S. on Plan to Spray Poppies", New York Times, October 8, 2007.

Shanker, Thom. "Pentagon Sees Aggressive Anti-Drug Effort in Afghanistan", New York Times, March 25, 2005.

Shanker, Thom. "Top Officials Greet Gates in Kabul with Pleas", New York Times, December 5, 2007.

Sieff, Kevin. "After Billions in US Investment, Afghan Roads are Falling Apart”, Washington Post, January 21, 2014.

Sieff, Kevin. "In Afghanistan, Underground Girls School Defies Taliban Edicts, Threats", Washington Post, April 25, 2012.

Shane, Scott. "CIA Interrogator's Defence to Cite Bush at Brutality Trial", New York Times, February 11, 2005.

Singh, Vikram. "Winning the Battle, Losing the Faith", New York Times, October 4, 2008.

Steele, Jonathan. "US Convinced Karzai Half-Brother is Corrupt, Wikileaks Cables Say", The Guardian, December 3, 2010.

Stephens, Joe and Ottaway, David. "A Rebuilding Plan Full of Cracks", Washington Post, November 20, 2005.

Stolberg, Sheryl. "Pressing Allies, President Warns of Afghan Battle", New York Times, February 16, 2007.

Surowiecki, James. "The Marshall Plan Myth”, The New Yorker, December, 2001.

The Economist, "Richard Holbrooke, Bullish and Bullying: The Rise of an American Diplomat", December 3, 2011.

Thompson, Mark. "Why the Pentagon Axed its Afghanistan Warlord", Time, May 12, 2009. 
Tisdall, Simon. "The Curious Sacking of Gen. McKiernan", The Guardian, May 13, 2009.

Totakhil, Habib and Abi-Habib, Maria. "US Winds Down Afghanistan Aid Program", Wall Street Journal, 10 October, 2012.

Transparency International, Corruption Perceptions Index, Berlin, 2007.

Tyson, Ann. "General David McKiernan Ousted as Top US Commander in Afghanistan", Washington Post, May 12, 2009.

United Nations. "Enhancing the Effectiveness of the Principle of Periodic and Genuine Elections: UN General Assembly Resolution 46/137, of December 17, 1991", reprinted in Yearbook of the United Nations 1991, Boston, 1992, 588-589.

- The Political Transition in Iraq: Report of the Fact-Finding Mission, New York, S/2004/140, 23 February 2004.

United Nations Assistance Mission in Afghanistan. Agreement on Provisional Arrangements in Afghanistan Pending the Re-establishment of Permanent Government Institutions, United Nations, December, 2001.

United Nations Development Program (UNDP). Human Development Report, April 2010.

United Nations Development Report, Afghanistan, 2013, 2.

United Nations Office on Drugs and Crime (UNODC). Afghanistan Farmer's Intentions Survey 2003/2004, February 2004, 5.

- Afghanistan Opium Survey, 2004.

- World Drug Report, June 2005.

- Corruption in Afghanistan, January 2010.

Waldman, Amy. “Afghan Leader Warily Backs US Bombing”, New York Times, January 2, 2002.

_ .Afghan Warlord's Rival Links Him to U.S. Attacks", New York Times, January 3, 2002.

Washington Times. "Nation-Building Elevated", December 14, 2005.

—. "Bush a Convert to Nation-building", April 7, 2008. ary 22, 2014. http://www.washingtontimes.com/news/2014/jan/22/WASTE/?page=all (accessed 22/01/2014).

Williams, Paul. "US Marines protect Afghanistan's poppy fields", Canada Free Press, July 8, 2009.

Wood, David. "Building Schools in Afghanistan: Not as Simple as ABC", Politics Daily, June 22, 2009.

World Bank. Governance Matters 2007: Worldwide Governance Indicators, 1996-2006, World Bank, Washington, DC, 2007.

\section{Government Documents}

Braun, Michael. Statement for the Record, US House of Representatives Foreign Affairs Committee, August 1, 2013.

Bush, George W. "Remarks at the 20th Anniversary of the National Endowment for Democracy", United States Chamber of Commerce, Washington DC, November 6, 2003.

- The Rights and Aspirations of the People of Afghanistan, The Whitehouse, July 8, 2004. http://georgewbushwhitehouse.archives.gov/infocus/afghanistan/20040708.html

Capra, James. Statement on "Future US Counter-Narcotics Efforts in Afghanistan", in his capacity as Chief of Operations, Drug Enforcement Administration, Before the Caucus on International Narcotics Control, United States Senate, Hearing, January 15, 2014. 


\section{Bibliography}

Carroll, Michael. Most Serious Management and Performance Challenges for the US Agency for International Development, Office of the Inspector General, 2013.

Center for Army. Lessons Learned, Agribusiness Teams in Afghanistan: Tactics, Techniques and Procedures, United States Combine Arms Center, Kansas, November, 2009.

Clinton, Hillary. Remarks at the Launch of the Asia Society's Series of Richard C. Holbrooke Memorial Addresses, New York, February 18, 2010.

Commission on Wartime Contracting. An Urgent Need: Coordinating Reconstruction and Stabilization in Contingency Operations, Washington DC, 2010.

Committee on Armed Services. Assessment of Security and Stability in Afghanistan and Development in U.S. Strategy and Operations, Author, House of Representatives, One Hundred Tenth Congress, Hearing, held February 13, 2007.

- Assessment of Security and Stability in Afghanistan and Development in U.S. Strategy and Operations, House of Representatives, One Hundred Tenth Congress, Second session, January 23, 2008.

- Assessment of U.S. Strategy and Operations in Afghanistan and the way ahead, House of Representatives, One Hundred Tenth Congress, Second Session Hearing, January 23, 2008.

Department of Justice, Mission Statement http://www.justice.gov/about/about.html Department of Defence. Quadrennial Defence Review Report, February 6, 2006,

- Report on Progress toward Security and Stability in Afghanistan, June 2008.

- News Briefing with Major General Cone from Afghanistan, November 12, 2008.

—. Toward Security and Stability in Afghanistan, Report on Progress, June 2009.

Report on Progress Toward Security and Stability in Afghanistan and United States Plans for Sustaining the Afghan National Security Forces, April, 2010.

Department of State. Frequently Asked Questions About the Office of the Coordinator for Reconstruction and Stabilization, July 15, 2008.

Department of State and Board of Broadcasting Governors. Report of Inspection Rule of Law Programs in Afghanistan, Office of the Inspector General, January 20, 2008

Department of State. Bureau for International Narcotics and Law Enforcement Affairs, International Narcotics Control Strategy Report - 2001 Southwest Asia, Washington DC, 2002.

- International Narcotics Control Strategy Volume 1 Drug and Chemical Control, March 2010.

Drug Enforcement Administration, Mission Statement, http://www.justice.gov/dea/about/ mission.shtml

FY2011 Performance Budget: Congressional Budget Submission, 2011, 3 and 10.

Feickert, Andrew. US Military Operations in the Global War on Terrorism: Afghanistan, Africa, the Philippines and Colombia, Congressional Research Service Report to Congress, Washington DC, The Library of Congress, 2005.

Government Accountability Office. Mission Statement, http://www.gao.gov/about/index. html

- Afghanistan Reconstruction: Deteriorating Security and Limited Resources Have Impeded Progress; Improvements in U.S. Strategy Needed, Washington DC, June 2004.

- Military Operations: Department of Defence Extensive Use of Logistics Support Contracts Requires Strengthened Oversight, Washington, DC, July 2004.

- Afghanistan Reconstruction: Despite some Progress, Deteriorating Security and Other Obstacles Continue to Threaten Achievement of U.S. Goals, Washington DC, July 2005. 
Securing, Stabilizing and Reconstructing Afghanistan: Key Issues for Congressional Oversight, Washington DC, May 2007.

Provincial Reconstruction Teams in Afghanistan and Iraq, Washington DC, October 2008.

- Military Operations: High-Level DOD Action Needed to Address Long-standing Problems with Management and Oversight of Contractors Supporting Deployed Forces, Washington DC, December 18, 2006.

—. Actions Needed to Better Guide Project Selection for Commander's Emergency Response Program and Improve Oversight, Washington DC, June 23, 2008.

- Afghanistan Reconstruction: Progress Made in Constructing Roads but Assessments for Determining Impact and a Suitable Maintenance Program Are Needed, Report to Congressional Committees, July 2008.

- Afghanistan Drug Control: Strategy Evolving and Progress Reported, but Interim Performance Targets and Evaluation of Justice Reform Efforts Needed, Washington DC, March 2010.

House of Representatives. Assessment of Security and Stability in Afghanistan and Development in U.S. One Hundred Tenth Congress, Hearing held on February 13, 2007.

- Agency Stovepipes vs. Strategic Agility: Lessons We Need to Learn from Provincial Reconstruction Teams in Iraq and Afghanistan; Report 41-409, April, 2008.

Proceedings and Debates of the 112th Congress, Second Session, 128: 26, Washington DC, February 16, 2012.

Inspectors General. U.S. Department of State and U.S. Department of Defence, Interagency Assessment of Afghanistan Police Training and Readiness, November 2006.

Inspector General. U.S. Department of State, Rule of Law Programs in Afghanistan: Report of Inspection, January 2008.

Johnson, Charles. "Reforming Afghanistan's National Police Force", Testimony Before the Subcommittee on National Security and Foreign Affairs, Committee on Oversight and Government Reform, House of Representatives, United States Government Accountability Office, June 18, 2008.

Johnson, Charles and Pickup, Sharon. Afghanistan Security: Long-standing Challenges May Affect Progress and Sustainment of Afghan National Security Forces, Testimony Before the Subcommittee on Oversight and Investigations, Armed Services Committee, House of Representatives, United States Government Accountability Office, 2012.

Johnson, David. Testimony for Oversight of US Efforts to Train and Equip Police and Enhance Justice Sector Reform in Afghanistan, Committee on Oversight and Government Reform, United States Department of State, International Narcotics Bureau, June 18, 2008.

Office of the Inspector General for Afghanistan Reconstruction (SIGAR). US Reconstruction Efforts in Afghanistan Would Benefit from a Finalized Comprehensive US AntiCorruption Strategy, August 5, 2010.

Office of Inspector General. Audit of USAID/Afghanistan's Incentives Driving Economic Alternatives For the North, East, and West Program, Kabul, June 29, 2012.

OMB, Mission Statement, http://www.whitehouse.gov/omb/organization_mission/

Petraeus, David. Testimony, before the Senate Armed Service Committee, Committee on Armed Services, March 16, 2010.

President's Committee on Government Organization. Dwight Eisenhower Library, August 23, 1966.

Ramon, Robert. Construction Program Improves Afghans Lives, American Forces Press Service, United States Department of Defence, April 14, 2006. 


\section{Bibliography}

Rennack, Dianne. Foreign Operations Appropriations, General Provisions, Congressional Research Service, Washington DC, August 12, 2011.

Rice, Condoleezza. Transformational Diplomacy, speech given at Georgetown University, Washington DC, January 18, 2006.

Rumsfeld, Donald. Department of Defence News Briefing, April 22, 2002.

Senate Caucus on International Narcotics Control. US Counter-Narcotics Strategy in Afghanistan, Author, Washington DC, July 2010.

Special Inspector General, Afghanistan Reconstruction (SIGAR). Action Needed to Resolve Construction Delays at the Counter-narcotics Center, August 27, 2009.

- Documenting Detention Procedures Will Help Ensure Counter-Narcotics Justice Center is Utilized as Intended, December 30, 2009.

- Quarterly Report to the United States Congress, Arlington, January 30, 2011.

Spevacek, Anne Marie. USAID Global Development Alliances (GDA) Predecessor Activity Inventory 1990-present, USAID Development Information Services, October 1, 2001.

Tarnoff, Curt. Afghanistan: US Foreign Assistance, Congressional Research Service, Washington DC, August 12, 2010.

The White House. National Security Presidential Directive 44, Washington DC, December 7, 2005.

Thibault, Michael and Shays, Christopher. At What Cost? Contingency Contracting in Afghanistan and Iraq: Preliminary Findings, Conflict Management, Commission on Wartime Contracting in Afghanistan and Iraq, April, 2010, 20-28.

United States Armed Forces (USAF). Commanders Emergency Response Program: Money as a Weapons System in Afghanistan, USAF, December, 2009

United States Army. Leader Challenges: Operation Enduring Freedom and Operation Iraqi Freedom, Center for Army Lessons Learned, Fort Leavenworth, Kansas, December, 2005.

- Southern Afghanistan COIN Operations Handbook: Tactics, Techniques and Procedures, Center for Army Lessons Learned, October, 2006.

- Rule of Law Handbook: A Practitioners Guide for Judge Advocates, The Judge Advocate General's Legal Center and School, Center for Law and Military Operations, Virginia, 2010.

United States Congress. Afghanistan Freedom and Security Support Act of 2007, Report 110-170, Section 104, Subsection B, 2007-2009.

United States Embassy Kabul (cable). "US-Afghan Partnership Creates New Institutions to Fight Corruption", December 2, 2009, https://www.wikileaks.org/plusd/ cables/09KABUL3853_a.html

United States Institute for Peace, Guiding Principles for Stabilization and Reconstruction, Author, Washington DC, 2009.

USAID. Fragile States Strategy, January 2005.

- Provincial Reconstruction Teams in Afghanistan: An Interagency Assessment, Washington DC, June 2006.

- Fact Sheet: Strategic Provincial Road - Southern and Eastern Afghanistan, USAID, Kabul, June 2011.

_.Hiring mechanisms, http://www.usaid.gov/work-usaid/careers/hiring-mechanisms/ personal-services-contractors

Vickers, Michael, Assistant Secretary of Defence. "Appendix III: Comments from the Department of Defence", in Afghanistan Drug Control: Strategy Evolving and Progress Reported, but Interim Performance Targets and Evaluation of Justice Reform Efforts Needed, Government Accountability Office, Washington DC, March 2010. 
Ward, Francis. Oversight of US Efforts to Train and Equip Police and Enhance Justice Sector Reform in Afghanistan, Committee on Oversight and Government Reform, June 18, 2008 .

Wickman, Tony. "New Afghan Roads Promote Peace, Prosperity", United States Department of Defence, September 23, 2009.

Wyler, Liana and Katzman, Kenneth. Afghanistan: US Rule of Law and Justice Sector Assistance, Congressional Research Service, November 9, 2010.

\section{Interviews}

Author Interview with a Senior State Department Official, Washington DC, April 15, 2012. Author Interview with a Senior Defence Department Official, Washington DC April 18, 2012.

Author Interview with a Senior State Department Official, Washington DC, April 18, 2012. Author Interview with a Senior USAID Official, Washington DC, April 19, 2012.

Author Interview with a Senior State Department Official, Washington DC April 21, 2012. Author Interview with a Senior USAID Official, Washington DC, April 23, 2012.

Author Interview with a US Military Commander, Washington DC, April 29, 2012.

Author Interview with a Senior State Department Official, Washington DC, April 30, 2012. Author Interview with a Senior Defence Department Official, via telephone, Sydney to Colorado, July 15, 2013. 



\section{Index}

Abzaid, John P. 81-2

Adams, Rick 99-100

Advanced Civilian Teams, usage 175

Afghan Auxiliary Police (AAP), creation

99; systemic problem, tactical solution 99

Afghan Border Police (ABP) 100

Afghan Constitution (2004), vagueness 138

Afghanistan: anarchy 33-4; Bush, impact (absence) 77; centralized authority, consolidation 31-2; civilian capacity, absence 80-1; common goals, establishment 73 ; communications framework, improvement 29; conflictridden southern provinces: roads, construction 124; U.S. commitment 119; constitution (1964), deficiencies 32; construction surge, requirement 117-18; counter-bureaucracy, involvement 72; Criminal Justice Task Force 154-5; cultural differences, impact 97; development strategy, problem 80; drug problem 139-40; drug trade 138; economic strategy, problem 80 ; European-style education, attempt 30 ; government, Northern Alliance positions 65-6; heroin trade, growth 160; Holbrooke role 180; illiterate villagers, reading programs 123 ; innovation, counter-bureaucracy (impact) 83-4; inter-agency collaboration, nongovernmental ideas 185-9; invasion, nation-building continuing 75 ; justice program, performance evaluations 154; legal mechanisms, absence 152; legal system: construction, U.S. agency involvement 152-3; problems 138-9; Liberal Parliament, creation 31; military/civilian divide, reason 81 ; military command, structure (impact) 81-2; military effort, success (claim) 144; military establishment access 81-2; Mujahedeen factions, impact 33; multilateral framework, discouragement (Rumsfeld) 78; national development strategy, requirement (USAID emphasis) 118-19; nation-building: Bush disinterest 56 ; priorities, perceptions (differences) 84-5; pursuit, USAID perspective 70; Rumsfeld avoidance 77-8; USAID efforts, problem 129; USAID opportunity 68-9; White House desire, expression 59; officials, experiences 189-90; operations, OMB reviews (problems) 84; perception (Rumsfeld) 90; political geography 107; political landscape, order (restoration) 28-9; political order, corruption/ violence (impact) 75; political strategy, requirement 80 ; power access, increase (USAID promise) 116-17; PRT, impact 203; rebuilding/populace revitalization, dilemma 62-3; reconstruction, USAID perception 69-70; regional despots, impact 107-8; Security Forces, problems 204-5; Soviet Union invasion (1979) 33; state-building project, USAID capacity (absence) 70; Taliban, impact 33-4; USAID policies, impact 83; USAID position, prominence 82; U.S. Armed Forces, presence 77; U.S. bombing campaign 58-9; U.S. Embassy power center 67-8; U.S. invasion/ execution: military establishment, impact 56-7; mission, coalition impact (absence) 58; U.S. nationbuilding, cooperation/commitment 
(importance) 61-2; warlords: CIA, relationship 105-10; claims, fraud 109-10; force and fear ruling 108-9

Afghanistan Freedom and Security Support Act (2007) 176

Afghanistan Reconstruction Group (ARG) 114; USAID, opinions (differences) 114-15

Afghan National Army (ANA) 206; funds, increase (Eikenberry/Durbin request) 93; initial problems 92; transformation, Pentagon interest 93

Afghan National Army (ANA), training: program 88; U.S. efforts $66,78,91-94$

Afghan National Civil Order Police (ANCOP), creation 98

Afghan National Police (ANP) 206; controversies 103; deficiencies 99-100; description (Brennan) 99-100; development 94; Dyncorp training inability 102; Eikenberry defense 104; evolution, problems 94-5; militia disorganization, comparison 96; program, problems 105; provisions, absence 95 ; training program, evisceration 207; war on drugs, loss 140

Afghan National Police (ANP) training: enterprise 88; program, division/ dispersal 96; U.S. efforts 94-105

Afghan National Security Forces 97-8

Afghan state: history 28-34

Afghan state, nation-building (relationship) 17

Africa, decolonization 19

agency: encroachment, USAID resistance 120-1; nomenclatures/lexicon 48; perception, culture (impact) 48

Agribusiness Development Teams (ADTs) 129-130, 206; activities, National Guard coordination (absence) 198-9; focus, government-building 131; operation, continuation 130-1

agricultural development, U.S. efforts 126

Albright, Madeline 25

Ali, Hazrat 141

Ali, Sher 29

Al Qaeda 1; CIA vendetta 109; fight 5; mission 66; operatives, impact 106

Alternative Livelihood Program (ALP): failure 128; poppy production, relationship 147; replacement, IDEA-NEW (impact) 128-9; USAID initiation 127

America unbound 4
Amir, Iron (death) 30

Anglo-Afghan war (1879) 29

Anti-Ballistic Missile Program 46

Anti-Corruption and bribery Office

(ABCO), understaffing 152

appointments, conveyer-belt system 189

Armitage, Richard 136

Army Civil Affairs Units 6; perspective 173-4

Army of Retribution (British retaliation) 29

Asia, decolonization 19

Austin, Lloyd 181

axis of evil 5

Bacevich, Andrew 21, 38, 41, 77

Barno, David 75, 77, 80; ANP formation assertion 97-8; appointment 180; bureaucratic problems 210; COIN impact, perception 163-4; headquarters 181; Khalilzad, interaction 181; military collaboration requirement 96

Bin Laden, Osama 1; capture 57

Black \& Veatch 124

bombing campaign (U.S.) 58-9

Bonn Agreement 151-2; nation-building aims, realization 66-7; parliamentary elections 163; responsibility, division 66

Bonn Conference (2001) 65; ANA program 92

Bosnia: civilian officials, U.S. military support 112; military, usage (Albright demand) 25; police training 101; premature power transition, U.S. acceptance 27; U.S. nation-building antipathy 59; U.S. nation-building efforts 20-2

Boutros-Ghali, Boutros 22

Bowen, Stuart 174-5

Bradley, Rusty 115

Brahimi Panel, peace-building definition 22-3

Brennan, John T. 99-100

Bumpers Amendment 129

bureaucracy: division/conflict 10; forces, diversity 9 ; foreign policy bureaucracy, studies 9; growth 9; natural enemy, U.S. President perspective 43; president, relationship 41-4; rationality, inflexibility 9; turf-conscious bureaucracy $170-1,210-11$

Bureaucracy (Wilson) 47

bureaucratic barriers, presidential breach 42 
bureaucratic delays, example 97

bureaucratic inertia (overcoming), political leadership (impact) 78

bureaucratic perceptions, bureaucratic interests (impact) 46

bureaucratic politics: literature, focus 49 ; nation-building, relationship 8-11, 35, 205-10; new bureaucratic politics model 44-51; rationalist theorist criticism $37-8$

bureaucratic resistance, Holbrooke perception 178

Bureau for Conflict and Stabilization Operations (CSO), creation 171-2

Bureau of International Narcotics and Law Enforcement Affairs (INL) 101, 207; activity 142-3; Condoleezza, challenge 146; counter-narcotics, involvement 140; Kabul support 146-7; nominal authority 103; protests 148

Bush Administration, focus 211

Bush Doctrine 4

Bush, George W. 1; democratic governance approach 206; foreign policy 74-5; leadership style, problem 77 ; nation-building attitude 56; War on Terror 42

Caldwell, William B. 60

Carter, James 21

Carter, Jimmy 45

Center for Complex Operations 174

Central Command (CENTCOM), Rumsfeld communication 57-8

Central Intelligence Agency (CIA): Afghanistan warlords, relationship 105-10; anti-Taliban Pushtun alliance 109; empowerment role 105-6;

Northern Alliance rapport 106; operatives, tribal leader questions 108 ; sovereign state, status 106; warlord strategy 206-7

Central Training Center 96

Charles, Bobby 146

Chemonics, USAID investments 121

Cheney, Dick 4; U.S. commitment 159

China, relations (economic perspective) 46

civilian agencies 199-202; reservations, military establishment dismissal 58 civilian branches, military command criticism (Rice frustration) 78-9 civilian capacity, absence $80-1$ civilian elements, military elements (friction) 198
Civilian Management Crisis Corps 174

Civilian Response Corps (CRC) 170

Civil-Military Operations Center, creation 21-2

Civil Operations and Revolutionary Development Support Program (CORDS) 21

Clinton, Hillary 172, 178

coalition-building, Powell pursuit 64

Coalition Humanitarian Liaison Cells (CHLC), creation 193

Cold War 20

collaborative mechanisms 210-11; failure 169

Combatant Commanders Integrated Collaboration Team 174

Combined Action Program (CAP) 21

Commanders' Emergency Response Program (CERP) 206; criticisms 114; funding: direction 182-3; initiatives 113-14; funds: availability 196-7; committing 125; soldiers, role 113

Commission on Wartime Contracting 71; Berger trial 124

common accountability frameworks 186 communication, channels

(establishment) 42

community-based enterprises, USAID preference 123

Congress 135-6

Congressional Research Service (CRS), ROL project spending estimates 154

Consortium for Election and Political Process Strengthening (CEPPS) 164

Contracting Officer's Representatives (COR), responsibility 134-5

contractors, impact 209

cooperation: conduit, individuals (impact) 176-85; government-based mechanisms 169-75; NATO 6; United Nations 6

coordinate planning 187

coordination problems 199-200

Council on Foreign Relations report 107-8

Counter-Bureaucracy 56

counter-bureaucracy 71-4; description 71; impact 83-4; meaning 71-2; USDA/

PRTs, relationship 202-3

counter-bureaucracy, interference (resentments) 83-4

counter-bureaucracy, term (usage) 12n43 counter-insurgency: avoidance 22; effort, U.S. engagement 201; ISAF evocation 61

Counter-Insurgency Doctrine (COIN) 60 ; codification 61 ; complement 162 ; 
failure 116; impact, Barno perception 163-4; influence 125; pervasiveness 62; priorities 114; projects, linkage 129; ROL projects $156-7$

counter-narcotics: chief, idea (Neumann perspective) 176; INL, devotion 154-5; law/governance, relationship 138; program 139-51; projects, linkage 129; U.S. approach, complexity/ disorganization 144-5; U.S. strategy 12

Counter-Narcotics Justice Center (CNJC), U.S. construction 154-5; disharmony 157

Counter-Narcotics Police, local law enforcement (collaboration) 149

Counter-Narcotics Sync Group (Kabul) 144

Country Reconstruction and Stabilization Group 170

Courter, Jeff 115

Criminal Justice Task Force 154-5

Crisis Group Asia 102

Crocker, Ryan C. 184

Crone, Robert 99

Cuba, blockade 39-40

cultural differences, impact 97

culture, impact 26

Daoud, Mohammad 31-2

Dayton Accords (1995) 21-2

Defense Department, Task Force Police

Directorate 96

defense/development/diplomacy 55

democracy: crystallization 159; elections, importance 162-3; promotion, nation-building (connection) 25-6

democratic governance, U.S. nation-building goal 206

Democratic Republic of Congo, U.S. nation-building efforts $20-1$

Department of Defense (DoD): Contracting Officer's Representatives (COR), responsibility 134-5; freedom 57

diplomacy, State Department interest 90, 159-60

Directive 3005, impact 62

"Directorate for Conflict Prevention and

Sustainable Security" 187

Disraeli, Benjamin 29

District Delivery Program 118

District Stabilization Framework 118

Dobbins, James 25, 65, 80, 117, 204; agenda 85

Docherty, Leo 115-16
Dostum, Abdul Rashid 59

Dostum, Rashid 106, 162

Drug Enforcement Administration (DEA): counter-narcotics, involvement 140; guidance, absence 207-8; military reliance 149; teams, embedding 143

Drug Flow Attack Strategy and Special Operation Division, impact 143-4

drug spraying, Gates perception 146-7

Dunleavy, Daniel 122

Durbin, Robert 93

Duty (Gates) 74

DynCorp International 101; training program, impact 101-2

economic growth, political growth (reinforcement) 27-8

Eikenberry, Karl 85, 93, 209-10; ANP perception 104; career 184; counter-narcotics efforts, absence 141; government legitimacy, loss 161; hostility, absence 182; Neumann, relationship 183; policy $182-3$

elections, importance 162-3

electoralism, fallacy 25-6

Embassy Interagency Planning Group, creation 180-1

England, Gordon 97

eradication: controversy 145-6; interdiction, State Department support 149-50

Eradication Working Group 144

ethno-sectarian fissures 1

factionalism, impact 63-4

Fine, Patrick 118, 163, 189

Focused District Development (FDD) program 98

foreign affairs, U.S. President decisions (impact) 41-2

Foreign Aid Sanction 46

foreigners, Afghani animosity 8

foreign militaries, support 91-2

foreign policy: bureaucracy: agendas, competition 105; studies 9; USAID position 68-9; coordination/ implementation, difficulty (Kissinger) 44; individuals, characteristics $40-1$; State Department conservative approach 63

Fragile State Strategy 55

Franks, Tommy 57, 78; Afghanistan freedom/prosperity 91-2

Fukuyama, Francis 25 
Galbraith, John 64

Galbraith, Robert 184

Gates, Robert 60, 74, 78, 171; disposition 79 ; drug spraying strategy perception 146-7; drug trade perception 141-2; impact (McKiernan job loss) 183; military casualty response 112 ; U.S. training program perception 94

General Accounting Office (GAO) 71, 84, 132; behavior 134; cooperation controversies 103; protest 104; scrutiny, advocacy 202

Germany, U.S. military occupation 19-20

Ghazni Province, police chief rank/money absence 95

global democracy 159

Global War on Terror (GWOT) 1; battlefronts, multiplicity 59 ; broadening 5; Bush Administration conception 8; compromise 209; impact 4, 185; nation-building, association 82 ; prosecution 157-8; shape/nature, NSC (impact) 175; U.S. execution 205-6

Gorbachev, Mikhail 33

Gormley, William 71

governance 158-65; counter-narcotics/ law, relationship 138; democratic governance, U.S. nation-building goal 206; good governance 7; promotion, mechanisms 164-5; system, Mullah exemptions 29; U.S. approach 159-60 government: failures, values (confusion)

38; Karzai government 12, 139-40,

161; legitimacy, loss 161-2

government-building, ADT focus 131

Government Counterinsurgency Guide 174

Grenada, invasion 45

Grossman, Mark 179

Haas, Richard 65, 91; Coordinator for the Future of Afghanistan role 67

Hadley, Steven 65

Hafvenstein, Joel 195

Haiti: police training 101; U.S. nation-building efforts $20-1$

Halfenstein, Joel 121

hard power 49

harmonization 186

Hass, Richard 64-5

Hayden, Caitlin M. 185

Helmand: cash-for-work project 119; CIA spending 118; drugs, presence 150; Kajaki Dam, repair/upgrade 119; problems 208
Helmer, Daniel 100

Herbst, John 171

heroin: supplier 138; Taliban exploitation 146; trade, growth 160

Holbrooke, Richard 43, 142, 147; Afghanistan role 180; bureaucratic resistance perspective 178; intruder status 207; Lute perception 178; "Machine That Fails, The" article 177; power asymmetry 179; Special Envoy appointment 176-7

Human Development Index 111

humanitarian relief 3

human rights, economic assistance linkage (Treasury Department battle) 45

Hunter, Duncan 135-6

Hussein, Saddam 46

ICITAP program 101

IDEA-NEW program, impact 128-9

illicit crop production, reduction 135

Improvised Explosive Devices (IEDs), potency (reduction) 124-5

Inderfurth, Karl 77

individuals, logic/rationality application (inability) 10

infrastructure development 3, 111; program, OMB encroachment 133; projects $122-32$; soldiers/commanders, understanding (problem) 148

infrastructure projects: foundation 122-3; military perception $113-14$

institutional fragility $1-2$

Integrated Civil-Military Campaign Plan (ICCP), implementation 184

Integration Planning Cell, usage 175

inter-agency cohesion 173

inter-agency collaboration: non-governmental ideas 185-9; PRT model 197-8

inter-agency competition/conflict, possibility (expansion) 43-4

inter-agency cooperation, rhetoric 60

interagency coordination, refinement 22

Interagency Counter-narcotics Working Group (Washington) 144

interagency implementation, oversight assistance (coordination) 176

Interagency Management System (IMS), creation 175

inter-agency operations, army role (RAND study) 188

Interagency Planning Group, marginalization 182 


\section{Index}

inter-agency problems 74-86

Interagency Resources Cell, marginalization 182

interdiction: military opposition 150; State Department support 149-50

international actors, impact 24-5

international alliance, problems 205

International Criminal Investigative

Training Assistance Program 101

International Foundation for Electoral Systems (IFES) 164

International Security Assistance Force (ISAF) 12, 88-91, 206; CHLC alternative 193; commitment, Rumsfeld opposition 90-1; counter-insurgency 61; effectiveness, limitation 89-90; formation 89; U.S. attitudes/ relationships 88

intra-agency cohesion 173

intra-governmental collaboration 186

intragovernment divisions, compartmentalization 73

investment, Marshal Plan 65

Iran (axis of evil member) 5

Iraq: axis of evil member 5; Bush preoccupation 75; U.S. Armed Forces, presence 77

Islam: conservative interpretation 151; lethal weapon 33

ISS-Safenet 124

\section{J-10 program 173-4}

Jackson Subcommittee (1963) 48

Jaffar, Sayyed 106

Jalalabad, State Department tours 200-1

Japan, U.S. military occupation 19-20

Jawbreaker 106

Joint Coordination Groups 174

Judge Advocate General (JAG) Corps, project organization 156

Justice Sector Support Program 152

Kabul: U.S. occupation 59

Kabul, electricity infrastructure 2

Kajaki Dam, repair/upgrade 119

Kandahar Province: hot spots, result

80; Nad Ali District, agriculture development projects 129; problems 208; Taliban: losses 59; strength 93-4

Karawaddin, winter coats/gloves (distribution) 115

Karzai, Hamid 7, 65; corruption 160-1; government: counter-narcotics strategy, criticism 140; opium cultivation/ trade 139; U.S. relationship 12, 161; ingratiation 138-9; interaction, Petraeus perception 179-80; nomination 65-6;

USAID arguments 83; U.S. puppet 160

Kennedy, John F. (bureaucracy problem) 43

Khalili, Abdul Karim 106

Khalilzad, Zalmay 85-6, 160; appointment 180; Barno, interaction 181; bureaucratic problems 210; initiation 118-19; Rumsfeld, interaction 181

Khan, Abdur Rahman 30

Khan, Amanullah 30; reforms, tribal opposition 30-1; replacement 31

Khan, Dost Mohammad 28-9; Britain, impact 29

Khan, Ismael (support) 198

Khan, Ismal 106

Khan, Yaqub 29

Khost-Gardez highway: contracts 124; cost, increase 125-6

Khost-Gardez road, collaborative projects 122

Kilcullen, David 131

Kissinger, Henry 44

Kosovo: civilian officials, U.S. military support 112; police training 101; premature power transition, U.S. acceptance 27; U.S. involvement, requirement 25; U.S. nation-building antipathy 59; U.S. nation-building efforts $20-2$

Lamm, David 181

large-scale bureaucratic organizations 8-9

law, counter-narcotics/governance (relationship) 138

legal system $151-8$

liberal-democratic constitutional orders, establishment 19-20

Liberal Parliament, creation 31

long-term projects, USAID preference $82-3$

Louis Berger Group Incorporated 121, 124

Lute, Douglas 178

Lynch, Adam 148

MacArthur, Douglas 42

Mahmud, Shah (liberal influences) 31

Maley, William 88

Malik, Abdul 162

Mann, James 38

Marshal Plan 19-20, 65

McCaffrey, Barry 99 
McChrystal, Stanley 131, 179; counter-insurgency strategy 184-5; derision 185; Eikenberry support 185; Petraeus perspective 183-4

McColl, John 89

McKiernan, David (Gates, impact) 183 military: casualties, Gates response 112; collaboration, requirement 96; command model, usage 187-8; counter-narcotics, mobilization (avoidance) 141; elements: civilian elements, friction 198; nation-building elements, disconnect 21; mentality, reconstruction impact 196-7; objective 206; occupation, impact 17 military establishment 56-63; cultural precepts, Rumsfeld acceptance 57; culture, warfare (foundation) 56; program 112-16; resources/manpower, impact 173; term, usage $12 \mathrm{n} 43$; U.S. civilian agencies, budgetary imbalance 79

military leadership: infallibility, COIN promotion 61 ; rhetoric 60

Military Operations Other Than War (MOOTW), impact 21-2

mission creep, inculcation 142 monolithic nation 40

Mujahedeen factions, impact 33-4

Mullen, Michael 171, 183

Murray, Craig 160-1

Musharraf, Pervez 5-6, 64

Myers, Richard 1, 57

Nad Ali District, agriculture development projects 129

Nagal, John 173

Nangarhar ADT, expertise 129-30

Nasr, Vali 179

National Defense University (NDU) report 187

national development strategy, requirement (USAID emphasis) 118-19

National Guard, ADT activities coordination (absence) 198-9

National Interagency Contingency Coordinating Group, creation (advocacy) 187

National Security Council (NSC): control 76; creation 175; meetings, impact 58, $126-7$

National Security Presidential Directive 44 (NSPD-44): impact 153; usage 172 national security, rational actor model (impact) 39
National Security Strategy 55

nation-building: Afghan state, relationship 17; aims 26, 55-6; bureaucratic politics, relationship 8-11, 35, 205-10; Bush disinterest 56; characterization $26-7$; contractors, impact 209; defining 18-24; democracy promotion, connection 25-6; efforts, direction/organization attempt 85; elements, military elements (disconnect) 21; enterprise, ambiguity 7; failures 23, 211; first-hand accounts 11; goals, accomplishment 75; lite 64-5; literature 3-8; conceptual confusion 18; method/structure 11-13; microcosm 193; objectives, confusion 74; origins, consideration 19; perception 133; practice 24-8; priorities, perceptions (differences) 84-5; requirements 9; responsibility, Rumsfeld/Wolfowitz avoidance 76; Rumsfeld, detrimental effect 209; sources 20; Stabilization and Reconstruction Operations (SROs), comparison 23; strategy, ANP complement 100-1; success, factors 27-8; support, U.S. military reluctance 60; U.S. foreign policy bureaucracy, relationship 55; Washington misunderstanding 210; White House antipathy 59 ; zenith $2-3$

NATO, cooperation 6

Natsios, Andrew 68, 209; initiatives $172-3$; overruling 117 ; regulatory bodies, impact 83-4; Rumsfeld communication 69

Nawa district: CIA spending 118; teachers, appearance (absence) 179

Neumann, Ronald 73, 79, 85, 145, 209; bureaucratic delays, example 97; counter-narcotics chief (idea), perception 176; Eikenberry, relationship 183; hostility, absence 182 ; perceptions 103

9/11 attacks, U.S. government reactions 38-9

non-governmental organizations (NGOs)

7, 28; projects, impact 75; role 11

Northern Alliance (NA) 56-7; Afghan government positions 65-6; framework, warlords (connection) 107; members, CIA rapport 106

Northern Thailand, USAID activities 122-3

North Korea (axis of evil member) 5

Nouri, al-Maliki 181

Nur, Atta Muhammad 59 


\section{Index}

Obama, Barack 176-7; surge, implementation 211

Office of Coordination for Reconstruction and Stabilization (S/CRS) 170, 207; counter-bureaucracy, connection (absence) 171; replacement 171-2

Office of Foreign Assistance (OFA), formation 174

Office of Management and Budget (OMB) 71, 132; fiscal road blocks 84; influence, NSC control 76; project opposition 132-3; scrutiny, advocacy 202

Office of Military Affairs, creation 172-3

Office of the Coordinator for

Reconstruction and Stabilization (S/CRS) 76

Office of the Inspector General for Afghanistan (OIG), policing arguments 104

Office of the Under Secretary of Defense for Policy (USDP), PRT guidance 199

Officers of the Inspectors General (OIG) 71

oilseeds, manufacture (USAID initiative) 129

Olson, Eric 7

Omar, Mullah 57

open-ended deployments/mission clarity problem, Bush perspective 74-5

Operation Enduring Freedom 56-7, 59

opium: buy-back strategies, failure 140; cultivation 139-40; eradication, controversy 145-6; Poppy Eradication Force, sustaining 147-8; production: revival, military establishment (nonreaction) 140-1; State Department concern 142; trade 139-40; escalation $141-2$; traders, military targets 150 orchards (substitution), poppies (usage) $135-6$

organization, culture (presence) 47-8

oversight 132-5; assistance, interagency implementation (coordination) 176

Pacific First strategy, Roosevelt veto 43

Pakistan (ISI) 109

Parker, Michelle 201

Parliamentary elections 163; occurrence (2010) 164

Pashtun tribal belt 5

Patton, David 114

peace-building 3, 18; Brahimi Panel definition $22-3$

peace enforcement 23 peacekeeping 23

Peck, Fred 17

peculiar preferences (Allison) 47

Pentagon: attacks 56; combat operations 162; Directive 3000.5 62; infrastructure development projects 133-4; reconstruction plans, problems $115-16$; strategic objective, disconnect 114

People's Democratic Party of Afghanistan (PDPA) 32; disintegration 32-3

perception: individual position, correlation 47; peculiar preferences 47; shaping 10

Perito, Robert 101

Perry, Marshall F. 121

personnel issues, coordination problems (relationship) 200

Peshawar Accords (1992) 33

Petraeus, David 173, 179

Poag, Philip 100

Police Reform Directorate 96

policing, OIG perspective 104

policy: integration 186; interpretation/ implementation 43-4

Policy Planning Division (DPP) 67

political apparatus (birth defect) 25

political growth, economic growth (reinforcement) 27-8

political order (establishment), culture (impact) 26

Popeye syndrome 77

Poppy Eradication Force, sustaining $147-8$

post-colonial state 20

post-conflict operations 3

post-conflict situations, nation-builder navigation $24-5$

post-war occupation and reconstruction 20

Powell, Colin 25, 64, 91; departure 146; military background, impact 67

power: asymmetry, Holbrooke perception 179; bureaucratic interests, relationship 48-9; channels, creation 50; hard/ soft power 49; matrix, operation 10; measurement 49 ; role 49

president, bureaucracy (relationship) 41-4

President Emperor 41

Presidential and Provincial Council Elections (2009) 164

Presidential Directive 56 (PDD56) 21-2

Presidential Power (Neustadt) 46

prisoners, noise torture 158

Program Assessment Rating Tool (PART), establishment 72

projects, OMB opposition 132-3 
Provincial Reconstruction Teams (PRTs) 193; civilian agencies, relationship 199-202; civilian presence 200; civil operational plans 171; compromise 194; counter-bureaucracy/USDA, relationship 202-3; impact 203; integration, success 194; inter-agency collaboration model 197-8; J-10 program 173-4; non-military component incorporation, failure (USAID inter-agency assessment) 198; performance, assumptions 195; praise/critique 194-5; USDA, impact 202-3; USDP guidance 199; U.S. military, relationship 195-9

Pushtun: funding, increase 178-9; leader, CIA approach 107; tribal traditions 151

Quadrennial Defense Reviews 55, 60 Quick Impact Program (QIP) funding mechanism 201

\section{Rashid, Ahmed 58}

rational actor entity, action (problems) 205-6 rational actor model (RAM) 35-41; assumptions, questioning 39; expansion 41; national security, relationship 39; problems 209; template 37; types 39-41; usefulness, limitations 35-6; value-maximizing choices 37

rationalist theorists, criticisms $37-8$

Reagan, Ronald 45

reconstruction, military (impact) 196-7

Regional Afghan Municipalities Program for Urban Populations (RAMP) 118-19

Regional Interagency Directorates (RIDs), creation $187-8$

regulation $132-5$

Rice, Condoleeza 65, 78, 172; civil-military relations model 193-4; INL challenge 146; Neumann encouragement 133

Roosevelt, Franklin D. (Pacific First strategy veto) 43

Roots of Peace project 135

Rule of Law (ROL): funding, identification 153-4; initiative 152; officials, absence 156; program, impact 153; projects 156-7; comparisons 155 ; spending, CRS estimation 154; Special Committee, coordination 155

Rumsfeld, Donald 4, 50, 57, 76; Afghanistan, perception 90; CENTCOM communication 57-8; decisions, Franks opinion 78; Khalilzad, interaction 181; multilateral framework, discouragement 78; nation-building impact, detriment 209; Natsios communication 69; position, solidification 59; replacement 60; responsibility, perception 158

Rusk, Dean 48

Salt I negotiations 46

Saqqao, Bacha 31

Sayyaf, Abdul Rasul 106

Schlesinger, Arthur 41

Schofield, Ken 84

schools: building, community group vetting 131-2; construction, Pentagon perspective 131

Schroen, Gary (CIA team) 106-7

Second World War: post-war developments 19-20; post-war U.S. nation-building efforts 25

security 88 ; promotion, efforts 7

Security Forces, problems 204-5

semi-autonomous actors, INL empowerment (problems) 102-3

Shah, Ahmand 28

Shah, Nadir (rule/assassination) 31

Sharia law, interpretations 151

Shar, Timur 28

Shultz, George 25

small-scale projects, implementation 196

soft power 49

Somalia: police training 101; U.S. nation-building antipathy 59

Sorensen, Ted 43

Soviet Union, bi-polar competition 19-20

Special Inspector General for Afghanistan Reconstruction (SIGAR) 71, 84, 132; anti-corruption initiative 134; project outcomes, problems 111; scrutiny, advocacy 202

Special Inspector General for Iraq Reconstruction (SIGIR) 174-5

Stabilization and reconstruction operations 18

Stabilization and Reconstruction Operations (SROs) 23; nation-building, comparison 23

staff postings, shortness 189-91

state-building 18

State Coordinator for Reconstruction and Stability (S/CRS), undermining 199

State Department 63-8; Afghanistan mission, division 67; appointment resentment 177-8; conservative approach 63; coordination, absence 199-200; 
division 148-9; factions, fragmentation 67; internal conflict 64; military establishment, proficiency (absence) 79; police training contractor change 104; Policy Planning Division (DPP) 67; Transformational Diplomacy Initiative 55; turf-conscious bureaucracy 210-22; USAID authority, conflict 117

state, focus $18-19$

Steinberg, Donald 69-70

Stoll, Brian 116

strategic guidance 187

strategic planning 186

Strategic Provincial Roads Project (SPRP) 123

strategy and reconstruction (S\&R) divisions 187

subcontractors, problems 121

synergistic engagement 186

Taliban: Afghanistan occupation 33-4; compliance, refusal 56-7; embracing 152; fall 92; heroin, exploitation 146; influence 113; insurgency 93,112 , 162 ; combating 130 ; emergence 60 , 132; justice, imposition 151; Kandahar Province loss 59; military victory (2001) 161; misrepresentation 7-8; post-Taliban environment, decisions 105-6; power shift 89-90; presence 98; removal 57; targets 125

Tarin Kowt, State Department tours 200-1

Task Force Saber 198

team-building 186

team support/structure 187

Tenet, George 57, 107; operatives, tribal leader questions 108

textiles, manufacture (USAID initiative) 129

Top-down approach 188

Tora Bora Mountains, Al Qaeda (presence) 106

training regime, direction 203

Transformational Diplomacy Initiative 55

tribal leaders: CIA operative questions 108; power, shift 89-90

Truman, Harry S. 175

Tupper, Benjamin 115-16, 162

turf-conscious bureaucracy 170-1, 210-11

Twin Trade Towers, Al Qaeda attacks 56

ulama (reinvestment) 31

United Nations: cooperation 6; UN-style peacekeeping 90
United Nations Office on Drugs and Crime 127; Task Force, resources (insufficiency) 140

United States: actions, unity of purpose 42; allies, responsibilities (division) 66; Army Peacekeeping Institute, usage 22; Cold War 20; counter-narcotics strategy 12; foreign policy: bureaucracy, disorder 3-4; collective behavior 9-10; imperial ambitions 17-18; military 195-9; nation-building, characterization 26-7; resources, shift 115; State Department, diplomatic mouthpiece 64; training program, tangible results 94

United States Agency for International Development (USAID) 68-70; activities 122-3; ARG opinions, differences 114-15; community-based enterprises 123; contractor reliance 120, 128; coordination: absence 199-200; perspective 82; cultural norms, application 120; developmental creed 68; Fragile State Strategy 55; funding mechanisms, access 201-2; manpower, absence 69; mentality 123; outsourcing reliance 208; power, increase 69; program 116-22; resources, absence 123; road-building projects, problems 124; rotation system, problems 200; state-building capacity, absence 70; State Department: authority, conflict 117; control 208

United States Anti-Expropriation policy 39

United States Armed Forces, Afghanistan/ Iraq presence 77

United States Army Corps of Engineers (USACE): capacity, excess 183; collaborative projects 122; State Department contracting 157

United States Army National Guard, ADT activities coordination (absence) 198-9

United States Department of Agriculture (USDA): civilian roles 193; coordination, absence 199-200; counter-bureaucracy/PRTs, relationship 202-3; experience 130; guidance, absence 207-8

United States Embassy, power center (Afghanistan) 67-8

United States foreign policy: bureaucracy, description 55; civilian side, military (relationship) 77-8; complexity 44; power distribution 49

United States Office for Contingency Operations (UOCO) 174-5 
United States President: characterization (Schlesinger) 41; policy direction, order execution (gap) 43

U.S. Armed Forces, mandate 60

U.S. foreign policy bureaucracy, nation-building (relationship) 55

Vendrel, Francesco 89

vertical reorganization, impact 188

Vickers, Michael 145

Viet Cong influence 21

Vietnam: CORDS program 76; U.S. nation-building antipathy 59 ; U.S. nation-building efforts $20-1$; U.S. strategy, component 61

Wankel, Doug 143

war: congressional declaration 42 ; victory, measurement 60
War Crimes Commission Hearing 23

warlords: CIA strategy 206-7; claims, fraud 109-10

Warneke, Mark R. 63

War on Terror 42; shape 64; U.S. Armed Forces, impact 77

Washington: bureaucracy, aggravation 86; staff rotation, reforming (problems) 190

Washington Consensus 38-9

Western, Craig 92

whole-of-government approach 2, 186; facilitation 170

whole-of-government response 9

Wolfowitz, Paul 5, 76

Wood, William 146-7, 209-10

Zadran, Pacha Khan 109

Zakheim, Dov 73-4, 80-1, 108, 209

Zinni, Anthony 175 
